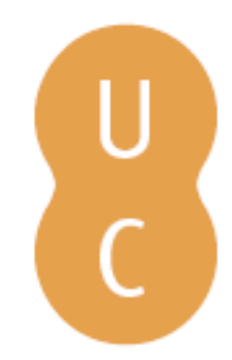

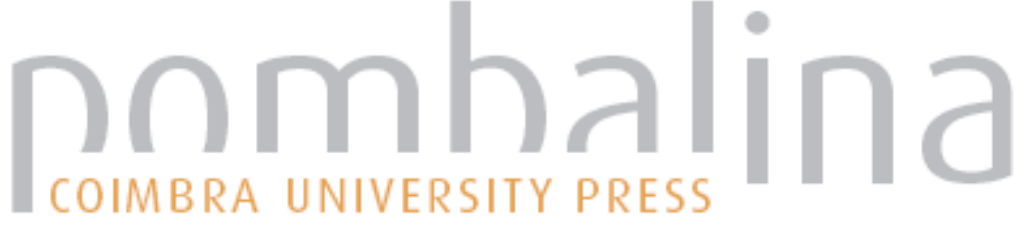

\section{Aesopica: a fábula esópica e a tradição fabular grega}

Autor(es): $\quad$ Ferreira, Nelson Henrique da Silva

Publicado por: Imprensa da Universidade de Coimbra

URL

persistente:

URI:http://hdl.handle.net/10316.2/29852

DOI:

DOI:http://dx.doi.org/10.14195/978-989-721-052-5

Accessed : $\quad$ 26-Apr-2023 14:05:09

A navegação consulta e descarregamento dos títulos inseridos nas Bibliotecas Digitais UC Digitalis, UC Pombalina e UC Impactum, pressupõem a aceitação plena e sem reservas dos Termos e Condições de Uso destas Bibliotecas Digitais, disponíveis em https://digitalis.uc.pt/pt-pt/termos.

Conforme exposto nos referidos Termos e Condições de Uso, o descarregamento de títulos de acesso restrito requer uma licença válida de autorização devendo o utilizador aceder ao(s) documento(s) a partir de um endereço de IP da instituição detentora da supramencionada licença.

Ao utilizador é apenas permitido o descarregamento para uso pessoal, pelo que o emprego do(s) título(s) descarregado(s) para outro fim, designadamente comercial, carece de autorização do respetivo autor ou editor da obra.

Na medida em que todas as obras da UC Digitalis se encontram protegidas pelo Código do Direito de Autor e Direitos Conexos e demais legislação aplicável, toda a cópia, parcial ou total, deste documento, nos casos em que é legalmente admitida, deverá conter ou fazer-se acompanhar por este aviso. 


\section{Aesopica}

\section{A FÁBULA ESÓPICA} E A TRADIÇÃO FABULAR GREGA

ESTUDO, TRADUÇÃO DO GREGO E NOTAS Nelson Henrique da Silva Ferreira 



\section{Aesopica}

\section{a fábula esópica e a tradição fabular grega}

ESTUdO, TRADUÇÃO DO GREGO E NOTAS

Nelson Henrique da Silva Ferreira

Universidade de Coimbra 
TODOS OS VOLUMES DESTA SÉRIE SÃO SUJEITOS A ARBITRAGEM CIENTÍFICA INDEPENDENTE.

Título • AESOPICA: A FÁbULA ESóPICA E A TRAdiçÃo FABUlar GREgA Autor • Nelson Henrique da Silva Ferreira

\section{SÉRIE TeXTos}

Coordenador Científico do plano de edição: Maria do Céu Fialho

\section{Conselho Edtorial}

José Ribeiro Ferreira

Maria de Fátima Silva

Diretor Técnico da Colecçấo:

Delfim Leão

\section{Obra realizada no ÂMBito das aCtividades da UI\&D Centro de Estudos Clássicos e Humanísticos}

EDIÇÃo

Imprensa da Universidade de Coimbra URL: http://www.uc.pt/imprensa_uc

E-mail:imprensauc@ci.uc.pt

Vendas online:

http://livrariadaimprensa.uc.pt

CoORdenAÇÃO EDITORIAL

Imprensa da Universidade de Coimbra

Concepçấo gráfica e Paginação

Rodolfo Lopes

INFOGRAFIA

Mickael Silva
Francisco de Oliveira

Nair Castro Soares
Impressão e ACABAmento

WWW.ARTIPOL.NET

ISBN

978-989-721-051-8

ISBN DigITAL

978-989-721-052-5

DOI

http://dx.doi.org/10.14195/978-989-721$052-5$

\section{Depósito Legal} $368781 / 13$

I a EdiçÃo: IUC • 2014

OBRA PUBLICADA COM O APOIO DE:

\section{FCT Fundação para a Ciência e a Tecnologia}

MINISTÉRIO DA CIÊNCIA, TECNOLOGIA E ENSINO SUPERIOR Portugal

(C) Fevereiro 2014.

Imprensa da Universidade de CoImbra

Classica Digitalia Vniversitatis Conimbrigensis (http://classicadigitalia.uc.pt) Centro de Estudos Clássicos e Humanísticos da Universidade de Coimbra

Reservados todos os direitos. Nos termos legais fica expressamente proibida a reproduçăo total ou parcial por qualquer meio, em papel ou em edição electrónica, sem autorizaçăo expressa dos titulares dos direitos. É desde já excepcionada a utilizaçăo em circuitos académicos fechados para apoio a leccionação ou extensấo cultural por via de $e$-learning. 


\section{SUMÁrio}

Notas PRELIMINARES

Propósitos da obra

Sobre a tradução

Agradecimentos

Siglas E abreviaturas

Parte I: A SABEDORIa POPUlaR E A TRAdiçÃo Fabular

1. INTRODUÇÃo

2. A tradiçấo POPULAR COMO VEÍ́culo

3. A imagética ANIMAL NA SABEDORIA POPUlaR

\section{A FÁBULA}

4.1. A fábula enquanto fórmula conceptual:

o debate acerca de um género.

4.2 A fábula greco-latina:

a definição de um género e a busca por uma tradiçáa.

4.3 A terminologia e conceptualização antigas e a identidade de um género.

a) Estrutura formal e processo narrativo.

b) A mecânica semântica da fábula: a alegoria e o mundo real.

c) A sentença, a acção e a moralidade.

d) Função e temática de um género adaptável.

PARTe II: A TRADIÇÃo ESÓPICA

1. Esopo

2. A FÁBULA ESÓPICA

3. Estrutura formal de um Conjunto e temática

4. A fábula esópica ENQUANTO FONTE histórica

5. As FONTES DA TRADIÇÃo FABULAR ESÓPICA

5.1. A reinvenção da fábula e o debate académico.

5.2 Transmissão do texto e fontes antigas. 
6. As COlectâneas de FÁbulas

7. Estabelecimento do TeXto GREgo E EDiçÃo de REFERÊNCIA 95

As Fábulas Esópicas

Bibliografia

Edições críticas e traduçôes

Estudos gerais

INDEX RERVM

INDEX LOCORVM

INDEX FABVLARVM

EDIÇỐES DO CORPUS FABULAR: TABELA DE CORRESPONDÊNCIA 


\section{NOTAS PRELIMINARES}

\section{Propósitos da obra}

Ainda que tenha gozado de uma fama intemporal e a sua tradição praticamente fundir-se com a própria matriz cultural mediterrânea, a fábula antiga não tem motivado um estudo sistemático no seio da academia portuguesa, quer seja a propósito da problemática que envolve a tradição e a transmissão dos textos que a compóem, quer seja no âmbito do estudo antropológico da sociedade e consequente mecânica genética deste género literário. Por esse motivo decidimos integrar neste trabalho um breve estudo que introduzisse a discussão que acarreta a tradição fabular e a recepçáo dos textos que chegaram aos dias de hoje.

Apesar de no nosso estudo, a dada altura, nos referirmos à fábula greco-latina (I.4.2 A fábula greco-latina: a definição de um género e a busca por uma tradição), não nos alongaremos na análise da tradição da fábula latina ou da fábula grega no âmbito da circulação e recepção dos 
textos no seio do Império Romano. Não por ausência de pertinência em tal estudo, em extensão ao que propomos, mas porque é nossa intenção retomar a problemática a quando da nossa publicação da tradução das fábulas de Fedro. Todavia, insistimos em designar o subcapítulo de "A fábula greco-latina” por nos parecer incoerente a separação entre a fábula grega e a latina, dado estarem intrinsecamente ligadas no que refere ao impacto da sua recepçáo.

No que refere ao estudo eàs referências às fontes antigas, devemos notar que alternamos entre o uso de abreviaturas dos títulos das obras em versão latina e o título completo em versão portuguesa. Pretendemos com isso distinguir as obras cuja consulta teve por base ediçóes críticas do texto original e as obras consultadas em versóes portuguesas. Isto porque tomámos a opçáo de, quando estava em causa o entendimento geral do texto ou um passo cuja necessidade de consulta não assentasse na análise semântica dos léxicos gregos ou latinos, consultar as respectivas traduçóes.

Notamos ainda que náo nos deteremos na figura de Esopo por dois motivos essenciais:

- Esopo é uma figura da tradiçáo cuja existência acaba por ser supérflua para o corpus que trabalhamos, dado que não existe uma relação autor/obra apenas tradição/colecçôes.

- As informaçóes referentes à figura de Esopo anteriores ao romance Vita Aesopica, para além de parcas são fragmentadas e pouco ou nada podemos, de momento, acrescentar ao estudo dessas notícias por parte de R. Adrados (Adrados 1999 vide 271-83). 


\section{Sobre a traduçáo}

Ainda que muitos textos apresentem lacunas ou variantes, dadas as diferentes notícias que uma mesma fábula pode ter, não nos deteremos na discussão das opçóes tomadas pela ediçáo critica de Perry. Tal comentário implicaria sempre o confronto com os manuscritos originais, assim como o domínio de técnicas de datação deste tipo de documentação - as técnicas actuais são elas próprias falíveis. Por esse motivo, obedecemos de uma maneira geral à lição de Perry (cf. Perry 1936 e 2007; vide II.4.5. Estabelecimento do texto grego e tradução). Todavia, alertamos para a edição crítica de Hausrath (1970), cuja grande mais valia reside na apresentação de variantes resultantes das diferentes colecçôes que preservaram estes textos, optando por não fazer uma selecção, quando em causa estão textos igualmente atestados na tradição.

Alertamos para o facto de, para além do corpus Aesopica, tomarmos a liberdade de traduzir duas fábulas antigas, transmitidas por Hesíodo e Heródoto, não porque tenhamos considerado que pertencessem à tradição esópica, mas antes por julgar oportuna a inclusão destes textos, dado representarem determinados elementos da tradição fabular grega.

Note-se que nem sempre a linguagem dos textos por nós traduzidos é a mais escorreita e adequada às concepçóes modernas deste género literário. Deve-se isso à nossa tentativa de levar a cabo, na medida do possível, uma tentativa de tradução fiel ao original, mantendo a clareza na língua portuguesa. 


\section{Agradecimentos}

Não registamos aqui a gratidáo dos afectos, pois qualquer amalgama de vocábulos seria parca em objectividade e ausente de uma manifesta validade, que só a personalização, em momento próprio torna possível. Por tal, agradecemos aos intervenientes directos na execução do trabalho que aqui publicamos. Deixamos uma palavra de gratidão ao nosso Mestre, o Professor José Ribeiro Ferreira, que nos emprestou os seus ensinamentos e correcção no decurso da execução do trabalho que apresentamos. Se acaso este trabalho se dota de qualidade, a ele será devida. Agradecemos também aos Doutores Nuno Simóes Rodrigues e Delfim F. Leão. Ao primeiro, pela estreita colaboração na primeira fase da execução deste trabalho, pelo avisado conselho e didáctica correcção. Ao segundo, não só por ter recebido com entusiasmo este projecto enquanto director dos Classica Digitalia, ramo editorial da UI\&D CECH da UC; mas também por, ainda em 2008, nos ter instigado a traduzir um pequeno conjunto de fábulas esópicas (baseadas na estrutura de Chambry), algo que viria a motivar um posterior estudo da imagética animal na literatura fabular grega, comparativamente com literatura sapiencial egípcia e, consequentemente, o estudo e tradução integral da fábula esópica que aqui apresentamos. Deixamos também uma palavra de apreço à Doutora Maria de Fátima pelo apoio formal e pessoal no âmbito do nosso projecto de Doutoramento Erasmus na Freie Universität Berlin, sem o qual teria sido manifestamente mais difícil compor este estudo de maior profundida analítica no que refere aos trabalhos dos autores e teóricos germânicos, que tanto contribuíram para a discussão do género fabular.

Por último, agradecemos à Doutora Maria do Céu Fialho, não só na pessoa de Directora da UI\&D Centro 
de Estudos Clássicos e Humanísticos da Universidade de Coimbra, ${ }^{*}$ mas também como orientadora da nossa bolsa de investigação e na qualidade de Mestre, que tanta sagacidade , paciência e ciência nos emprestou.

Nelson Henrique da Silva Ferreira

27/7/2013 Berlim

* Este trabalho foi concluído no âmbito de uma Missão Científica Humanísticos (31 de Agosto - 12 de Novembro de 2012) apoiada pela UI\&D CECH da UC e decorrida no final do ano de 2012. Da mesma forma, o estudo que aqui desenvolvemos foi também consequência do nosso projecto de Erasmus de Doutoramentos a decorrer no ano lectivo de 2012/2013 na Freie Universität Berlin . 

El meu vell em mirava amb nostalgia $i$ em xiuxiuejava en un alemany macarrònic i desvorgonyit:

"Ich glaube das ich durch Zufall von Vermögen war geboren: die Kombination aus einem Bus und einer Wäscherei. Jeman rief von unten von mir ,186' und ich erinnerte mich an eine bestimmte Fabel. Ich vergesse nicht, den Wunsch, in einem Traum, der einst eine Stadt und heute ist das Universum, dass ich lichtet klug."

Ismael Kurfürstendamm F. R. S. Celsius, 6 de Abril 



\section{AesopicA}

\section{A FÁBULA ESÓPICA E A TRADIÇÃO FABULAR GREGA}





\section{Siglas E ABREVIATURAS}

All - Heraclitus, Allegoriae

Aphthonius (Aftónio) - Aphthonius, Progymnasmata

Aves - Coulon, V. (ed.), van Daele, H. (trad.) (1967). Aristophane. vol. 3. Paris, Les Belles Lettres. 1928, Repr. (1st edn. corr.).

Ch. - Chambry, Émile (2005), Ésope. Fables. Paris, Les belles Lettres.

Diog. Laert. - Marcovich, Miroslav; Gärtner, Hans (eds.) (1999), Diogenis Laertii Vitae philosophorum, Volume I: Libri I. Berlin, De Gruyter.

CGF - Kaibel, George (ed.) (1958), Comicorum Graecorum Fragmenta. Berlin, Weidmann.

Fab. - Fabulae

Fab. Aes. - Fedro, Fabulae Aesopiae

Foerster - Foerster R. (ed.) (1903-27), Libanii Opera. 12 vols. Bibliotheca Scriptorum Graecorum et Romanorum Teubneriana. Leipzig, Teubner.

FGrH-Jacoby, F.(ed.) (1954-64), Fragmente der griechischen Historiker. Leiden, Brill.

FHG - Fragmenta Historicorum Graecorum, ed. C. Müller frg. - fragmento

IEG - Iambi et Elegi Graeci ante Alexandrum cantati, ed. M. West

Inst. - M. Fabius Quintilianus. Institutio Oratoria - 
Winterbottom, M. ed. (1970), M. Fabi Quintiliani Institutionis Oratoriae Libri Duodecim. Vols. 1-2. Oxford, Oxford University Press.

Hist. - Herodotus, Historiae.

Hsr. - Hausrath, A. (1970), Corpus Fabularum Aesopicarum. Vol. I, Fasc. 1. Leipzig, Teubner. Hausrath, A. (1959), Corpus Fabularum Aesopicarum. Vol. I, Fasc. 2. Leipzig, Teubner.

Hsch - Hesychii Alexandrini Lexicon, editionem post Kurt Latte continuans recensuit et emendavit

LSJ - Greek-English Lexicon, ed. Liddell-Scott-Jones.

Mem. - Xenofonte, Memorabilia

Noct. att. - Aulus Gellius, Noctes atticae

Op. - Hesiod, Opera et dies

Pap. gr. Vindob. - Papyrus graeca Vindobonensis

Perry - Perry, B. Edwin (2007), Aesopica. Chicago, University of Illinois Press.

$P C G$ - Kassel, Rudolf \& Austin, Colin (eds.) (19832000), Poetae Comici Graeci 8 vols. Berlin, de Gruyter.

Phaedo - Burnet, J. (ed.) (1900, Repr. 1967), Platonis opera, vol. 1, Oxford, Clarendon Press.

P.Köln - Papyrologica Coloniensia

P.Oxy. - The Oxyrhynchus Papyri

OCD - Hornblower, Simon \& Spawforth, Antony Spawforth (1996), The Oxford Classical Dictionary. Oxford. Oxford University Press.

Radt - Rad, Stefan (ed.) (1999), Tragicorum Graecorum 
fragmenta, vol. 1-4. Göttingen, Vandenhoeck \& Ruprecht.

Rh. - Kassel, Rudolfus (Ed.) (1976), Artistotelis. Ars Rhetorica. Berlin, De Gruyter.

Solmsen - Solmsen, Friedrich (ed.) (1970), Hesiodi. Theogonia. Opera et Dies. Scutum. Oxford, Oxford University Press.

Téon - Aelius Theon Rhet., Progymnasmata, "Rhetores Graeci, vol. 2”, Ed. Spengel, L. Leipzig: Teubner, 1854, Repr. 1966.

TLL - Thesaurus Linguae Latinae

TLG - Thesaurus Linguae Graecaei

\section{Sinais gráficos na tradução:}

[] - Acréscimo pelo editor ao texto fragmentado.

() - Acréscimo de conteúdo pelo tradutor. 



\section{Parte I}

A SABEDORIA POPULAR E A TRADIÇÃO FABULAR 



\section{INTRODUÇÃo}

O que é a tradição popular e em que medida contribui para a concretização de uma cultura? De um modo algo simplista, poderíamos considerar tal questão evocando o vulgarizado 'diz-se' e a sua propagação num determinado momento espácio-temporal. Esse mesmo 'dito' pode tratar simplesmente técnicas de caça, pastoreio ou horticultura; uma história de alcova sobre uma personalidade relevante, uma peripécia vivida por alguém ou, entre várias possibilidades, uma historieta com um fundo didáctico.

Os saberes, que usualmente se servem da tradição popular como veículo, têm um propósito educacional universal. Isto é, assumem a função de instruir uma sociedade, baseando-se numa sabedoria do senso comum e natural, promotora de equilíbrio nas suas relaçóes e instrução para a subsistência do indivíduo e do conjunto populacional onde se insere. De certa forma, estes saberes são o garante da protecção do indivíduo porque o auxiliam na obediência e no entendimento do comportamento moral humano. Note-se que a moralidade não é, neste âmbito particular, um conceito cerrado a interpretaçóes ou transversal a todo o universo dos homens. Na verdade, quando comentamos as expressóes "comportamento moral" ou "preservação da moral", temos apenas em consideração o objectivo primário da transmissão destes conhecimentos populares: a sobrevivência do 'eu' e da sua comunidade. Se tomarmos como exemplo de referência um possível ensinamento de uma técnica de caça antiga, dificilmente 
encontraríamos alguma questão moral, quando analisada à luz da concepção moderna - ocidental e judaico-cristã. No entanto, naquilo que é a concepção imediata da moralidade, este ensinamento permite a preservação da comunidade ao optimizar a capacidade de obter recursos do indivíduo para si e para o seu núcleo familiar ou social, do qual está invariavelmente dependente.

Como já referimos, estes saberes tradicionais corporizam-se na transmissão de conhecimentos práticos ou ensinamentos acerca de comportamentos e actividades das partículas constituintes das várias sociedades humanas. Esta sabedoria popular pode ou não ser válida quando analisada à luz do empirismo crítico. Todavia, independentemente da sua correcçẫo ou ciência, obedece ao principio cognitivo do senso comum e à analogia com o mundo natural - dado que esse mundo natural não só está enraizado na experiencia do indivíduo, que com ele toma contacto, como também na experiencia tradicional do seu contexto social. Desta forma, são criadas no imaginário humano as explicaçóes e propósitos do mundo natural, pelo que a tradição se ocupa de transmitir esses mesmos conhecimentos, de modo que não seja necessário ao indivíduo ou à sociedade experienciar novamente as vivências que os refutariam. $\mathrm{O}$ conhecimento enraíza-se na estrutura identitária da própria comunidade, ou seja na matriz cultural. Sendo assim, os seus valores ou ensinamentos são dados já como adquiridos a quando de uma experiência que os evoca. Dessa forma se cria um sistema de saberes que podem servir de instrumento crítico e promover a analogia com outras vivências que, ou não foram praticadas, ou cuja explicaçáo carece de ferramentas argumentativas mais complexas do que a própria situação ou ideia em causa. 
A título de exemplo, lembramos o significado da palavra portuguesa 'cobra', quando usada como forma de insultar alguém. Esta palavra por si só explica a perfídia de algum que ataca quando menos se espera e, ainda por cima, é peçonhento, envenenando ideias e relaçôes. Ora, toda esta definição está contida na imagem da 'cobra' e na analogia que o senso-comum faz entre a imagem deste animal e o comportamento dos homens. Em suma, a analogia é por excelência a ferramenta que transforma a definição de ideias algo complexas em imagens imediatamente concretizáveis no pensamento abstracto humano. 



\section{A tradiçấo PopUlar COMO Veículo}

Independentemente do objecto narrado, a tradição popular e a sua manifestação oral são a mecânica que permite cristalizar uma narrativa numa cultura e da mesma forma fundi-la na sua matriz - de tal modo que, em caso de contacto intercultural, a dita narrativa pode ser assimilada por outros receptores e integrada de forma espontânea na sua própria matriz cultural. Isto porque se encararmos outros mecanismos de cristalização de tradiçôes, como seja a literatura, verificamos que estes não potenciam a fusão natural dos seus conteúdos numa cultura, antes são absorvidos artificialmente, sendo complementos e não componentes da cultura que os acolhe.

Claro está, tomamos estas considerações tendo presente a transmissão da literatura ou arte plástica entre culturas, como seja a recepção dos poemas homéricos na literatura ocidental. A Ilíada é uma pedra basilar não apenas no culto do género épico, mas também é fonte temática para muitas obras da literatura dos dois últimos milénios. Ainda assim, é um produto da cultura e tradição literária gregas e é desta forma assimilada pelas culturas que a recebem. Apesar desta obra poder ela própria criar uma tradição autónoma, quando recebida numa cultura, essa tradição não deixa de ser uma reinvenção, originária de circuitos distantes daquilo que é matriz substancial da cultura. Em última análise, poderíamos até considerar que a própria Ilíada é o resultado de várias confluências culturais da antiga Hélade, uma vez que este texto parece incluir elementos de outras povos ou 
tradiçôes. Porém, a cultura grega aglomerou e recriou esse conjunto de materiais criando um produto que, quando recebido por culturas que não a helénica, é tomado como um objecto final e cristalizado e, dessa forma, intocável e incapaz de se fundir com a matriz do seu receptor. Ou seja, está em causa uma fonte independente, constituinte da matriz cultural ocidental, e não necessariamente um elemento que tenha sido produzido por essa matriz. Isto porque não é lícito tomar-se a civilização ocidental como um descendente directo da cultura grega, mas como um herdeiro da mesma.

Portanto, a tradição popular ocupa-se daquilo que são os elementos mais básicos e as necessidades mais prementes da estrutura de uma sociedade complexa, como sejam: a preservação de uma história que de alguma forma explique um determinado momento presente; ou a transmissão de um conhecimento que se faça útil à continuidade da sociedade onde se manifesta.

Esse saber, como já referimos, pode manifestar-se numa simples técnica laboral, útil no quotidiano, ou na exposição de determinadas atitudes perante a vida que podem ser prejudiciais ou benéficas ao homem, dependendo do seu manuseio e conhecimento. De certa forma, a própria ideia de 'moral' pode basear-se neste principio, dado que a moral não é mais do que a identificação de princípios que permitem a subsistência harmónica numa determinada sociedade, mas cujo principal motor é o indivíduo (vide supra). Ora, não é nossa pretensão avançar para um estudo epistemológico da Moralidade ou sequer criticar o conceito de Ética, até pela complexa subjectividade que lhes é inerente. Antes entendemos pertinente notar o interessante conjunto de conceitos, também eles variáveis, que integram a realização da moral numa sociedade complexa. Desde 
logo porque são esses mesmos conceitos que viajam pela tradição popular, e não tanto o conceito geral e abstracto de moralidade. Repara-se que noçóes simples como a perseverança, resiliência, bondade, trabalho, inteligência ou malícia são pouco mutáveis naquilo que é a sua função para a harmonia social. Estas são independentes de variaçóes impostas pela análise moral de ideias políticas, religiosas ou mesmo concepçóes biológicas. $\mathrm{Na}$ maioria das situaçóes em que estes conceitos se manifestam dentro do quotidiano social, implicam a relaçáo humana e o equilíbrio justo estre os indivíduos que constituem essa relação e o próprio mundo natural que os envolve. Ora, veja-se o homem que cultiva o campo deve ser perseverante e trabalhador, pois só assim conseguirá obter o produto de subsistência. Falhe ele no cumprimento dessas premissas, trará a si o risco de fome, pelo que atentará contra a moralidade, na medida em que falha na sua própria subsistência.

Tomemos por exemplo para a validade da tradição popular e oral algumas fábulas contadas nos dias de hoje e que podem encontrar paralelo seja na fábula esópica, seja na tradiçẫo Suméria (vide Williams 1956). Neste ponto, tomamos a liberdade de usar o testemunho pessoal, provavelmente comum ao leitor. Há várias anos, foi-nos contada a seguinte fábula:

"Um dia, o vento e o sol decidiram apostar quem conseguia tirar o casaco a um homem que estava por ali. Entáo, o vento soprou e o homem abotoou o casaco. Seguidamente, voltou a soprar com mais força, mas náo lhe arrancou o casaco e o homem abotoou-o ainda mais. Por fim, soprou com tanta força, que o homem fechou completamente o casaco. Mas quando chegou a vez do Sol, este brilhou com 
tanta intensidade que o homem, cheio de calor, tirou o casaco.”

Este exemplo, com paralelo na fábula esópica Bóreas e Hélios (F. 46 = Perry 46), foi-me contado sem que o narrador conhecesse o corpus fabular antigo ou tivesse sequer lido Jean de La Fontaine. Na verdade, nem seria capaz de identificar quem lha tinha contado na sua infância ou em que circunstância. Esta será uma peripécia em que muitos já se terão encontrado (cf. McCartney 1956). Quando me foi contada tal estória, era vontade do narrador ensinar-me que a precipitação não leva a lado nenhum e só potencia a asneira. Portanto, estaria aqui em causa o ensino da paciência e da ponderaçáo a uma criança, sob a forma de um exemplo prático, facilmente inteligível e sem que em nenhum momento esses conceitos fossem nomeados ou interpretados. Esta forma de ensino pela alegoria é uma manifestação da tradição popular e apresenta um dos vários veículos expressivos usados na transmissão dos saberes do senso-comum de uma sociedade. 


\section{A imagética ANimal Na SAbEdoria popular}

Os estudos etiológicos tornam-se imperativos para a compreensão da humanidade, enquanto colectividade social, e do homem, enquanto indivíduo. Contudo, a sociedade e os seus códigos assentam sobre processos culturais evolutivos de tal forma antigos, que apenas de forma conjectural podemos expectar reconhecer a sua origem e motivação. Tal sucede com a expressividade comunicacional e com a aquisição de determinados códigos linguísticos que têm por base uma tradição popular que, por seu turno, se baseia na observação da natureza e consequente conceptualização dos seus observados elementos constituintes. Note-se que, sempre que falamos em códigos linguísticos, temos intenção de referir a linguagem de expressão, como sejam a literatura, a iconografia e a linguagem popular - não exclusivamente a língua e as suas regras.

A imagética animal popular, originária da tradicional metáfora ou alegoria - tão caras à literatura universal -, ascende a um período pré-histórico, que terá tido por motivação o sistema cognitivo que acima referimos. ${ }^{1} \mathrm{~A}$ propósito, é nossa intenção notar que alguns animais têm características físicas e comportamentais passíveis de serem convertidas em signos linguísticos. E esses signos enraizavam-se de tal forma na cultura, que a simples evocação da imagem do animal implicava e implica o entendimento espontâneo dessas características (vide supra ex. a cobra

${ }^{1}$ Para um estudo teórico da metáfora, da alegoria e da analogia vide Coenen 2002. 
como insulto). Portanto, a metáfora assumiu um papel de relevo inquestionável na comunicação linguística abstracta. De resto, esta é, por excelência, a forma de comunicação usada nas relaçóes humanas. Fazemos esta afirmação, tendo presentes a expressão plástica, literária ou o desenvolvimento de monólogos e diálogos complexos, que não têm como objecto a transmissão de informação objectiva e de prática do quotidiano.

Ora, as características dos animais e a sua humanização, enquanto códigos de língua, obedeceram a um processo equivalente e registável em todas as culturas escritas, ao longo de vários períodos. De tal forma que é possível fazerse um paralelo imediato com a imagética de determinados animais entre diferentes culturas, mas com faunas e sistemas sociais equivalentes. Além disso, mesmo quando se verifica uma diferença substancial das faunas regionais das culturas em paralelo, é possível encontrar as mesmas características humanas simbolizadas por diferentes animais. A isso se deverá o pré-conceito que o senso-comum aplica à observação comportamental dos animais, ao partir de características humanas para definiçôes zoológicas (cf. Douglas 1994). Ou seja, o homem tendencialmente humaniza o comportamento animal, julgando em função das concepçóes e natureza próprias do ser humano.

Ainda que neste nosso breve ensaio tenhamos por referência os símbolos populares que a fábula esópica carrega, toda a literatura grega é permeável à identificação tanto do símbolo animal como das características destes quando em situaçôes humanizáveis. A propósito, bastará recordar as metáforas úteis à retórica do discurso ático (vide Ferreira 
2011) ou até poemas épicos ${ }^{2}$ que colocam duas espécies animais em confronto, como fossem gregos e troianos, como seja a Batracomiomaquia (vide Lopes 2008). Todavia, consideramos justificável esta nossa análise com a fábula esópica como fonte exclusiva, pois a sua simplicidade preserva os vestígios de uma linguagem popular, que se faz útil para a confrontação com outras culturas (vide Ferreira 2012). Pois, o princípio que dá origem a essa forma de linguagem é universalmente transversal: o contacto com a natureza.

Este contacto com a natureza e a sapiência que o senso-comum transporta criam espaço para o ensinamento da tradição popular, promotora da sabedoria e do conhecimento concreto, sem que este derive exactamente da experiência. Isto é, a tradição ensina a experiência de uma cultura e não directamente do indivíduo. Nesse sentido, poderemos julgar a alegoria animal e a sua origem no contacto com o mundo natural como o resultado de uma tradição que preserva o empirismo original nos saberes de uma determinada cultura. E um dos mais célebres e transversais exemplos é a raposa (cf. Krappe 1944). De facto, este animal surge recorrentemente na fábula, uma vez que promove um vasto leque de possibilidades para o ensinamento da moralidade. Tradicionalmente a raposa é um animal que sobrevive à custa da astúcia. Este atributo pode por si só, dependendo do contexto, implicar sabedoria ou malícia, e é a partir da 'esperteza' da raposa que a 'fábula esópica' vai construir muitas dos suas peripécias e consequentes sentenças - quer demonstrando que a sabedoria é a ferramenta ideal para resolver problemas, quer avisando

${ }^{2}$ Referimo-nos neste ponto à épica enquanto temática universal e não exactamente convenção formal da antiga literatura grega, parodiada na obra Batracomiomaquia. 
do perigo do 'chico espertismo' ou mesmo notando que há que estar atento à malícia dos ardis dos espertos ( $\delta$ ó Detienne, M. \& Vernant J.-P 1991).

Sendo o saber do senso-comum um dado adquirido, há que transformá-lo num ensinamento. Aí a fábula desempenha um papel preponderante, pois consegue promover a junção da moralidade útil ao indivíduo com o conhecimento tradicional - no caso concreto da fábula esópica: a liçâo com a alegoria animal. 


\section{A fábula}

\subsection{A fábula enQuanto Fórmula conceptual: O DEBATE ACERCA DE UM GÉNERO}

Até ao momento, ainda não foram encontradas evidências de uma nomenclatura antiga para os textos sumérios e acádicos de carácter fabular. Pode este facto dever-se ao reduzido corpus literário que nos chegou, além da grande quantidade de textos que aguardam publicação. $\mathrm{O}$ carácter algo inseguro dos estudos linguísticos destas línguas, especialmente a suméria, dificulta o próprio estudo da sua literatura. No entanto, existem várias ocorrências de textos fabulares, cuja semelhança estrutural com a fábula esópica levou muitos historiadores a considerar a influência directa destas culturas sobre a cultura grega.

Da primeira metade do II milénio a.C. chega a evidência escrita mais antiga da existência de fábulas sumérias, que corresponderia a parte do curriculum escolar da Antiga Babilónia - tinha como propósito o exercício da retórica (vide Falkowitz 1984). Gordon (1958) intitula, entre outros textos do corpus sumério, as narrativas "Burro e cão", "Leão e cabra”, "Dez lobos" e "Cão e figo"; Gragg (1973) acrescenta a esta lista a fábula "A garça e a tartaruga", cuja temática encontra paralelo no texto acádico "A águia e a Cobra", incorporado no mito acádico de Etana. Esta última, para além de corresponder ao texto fabular acádico mais antigo (Antigo período babilónico), parece ter gozado de uma sistemática circulação não só pelas regióes da Mesopotâmia e Levante, mas também pelo vale do 
nilo. Alguns estudiosos, dada a circulação destes textos e a proximidade temática com a fábula esópica, tendem a sugerir uma relação directa entre os vários corpus fabulares da bacia mediterrânica (vide Akimoto 2010). De resto, esse argumento pode ter a sua base de fundamentação na ocorrência de animais em fábulas, cuja tradição não se adequa ao ambiente natural do animal. Justificar-se-ia este fenómeno com o cruzamento entre as várias tradiçóes fabulares e a assimilação de conteúdos entre as várias narrativas. Podem tomar-se os exemplos de crocodilos, macacos, escaravelhos e camelos. No que refere a estes animais, a fonte primordial pode ter sido o antigo Egipto (cf. F. 32), podendo a tradição ter surgido pelo contacto directo - durante e depois do período helenístico - , ou pela inclusão na tradição fabular grega de temáticas tradicionais anteriores com origem no antigo Egipto.

Ainda que seja evidente a proximidade da fábula suméria "cão e figo" com a fábula esópica "A raposa e as uvas" (F. 15); ou da fábula acádica "O mosquito e o elefante" com a fábula esópica "O leão, Prometeu e o elefante" (F. 259), resistimos à ideia inequívoca de uma influência directa, pois falta-nos o acesso a um espectro maior de textos, quer orientais, quer gregos. Além disso, comparativamente, o registo escrito literário grego é no mínimo um milénio mais recente que o uso regular da escrita literária nas culturas da antiga mesopotâmia, o que reduz a capacidade de localizar no tempo registos de fábulas gregas em períodos anteriores ao século VI a.C.; e, por conseguinte, não é possível conhecer a antiguidade desta tradição no espaço da cultura pré-histórica grega. Apenas podemos sugerir que a tradição fabular ou proverbial são anteriores a sua concepção enquanto género e manifestação material (cf. exemplo analisado por Cons 1924). 
A sugestão de uma definição da fábula, enquanto género literário da antiguidade e contemporaneidade, implica um debate de contornos tão problemáticos quanto a redescoberta da cultura originária deste género. ${ }^{3}$ Neste segundo ponto, colocamo-nos sob a capa defensiva e confortável de termos como sejam a dificuldade, a imprecisão ou a subjectividade, para não apresentarmos qualquer proposta que ajude o leitor a localizar o nascimento da fábula num mapa conjugador de variáveis tais como a etnologia, a antropologia, a linguística e a geografia. Na verdade, é do nosso entendimento que tal tarefa não é exequível; pelo menos não com os dados que hoje possuímos. E passamos a justificar-nos com um certame estimulado por Ronald Williams (Williams 1956), no âmbito da publicação de uma tradução selecta de algumas 'fábulas esópicas' pela Pengin Classics. Este criticou a seguinte afirmação de Handford (1954) sobre as obras de Hesíodo e de Arquiloco:

"These poems are several centuries earlier than the earliest known fables of any other country (...) There is reason to believe that some Egyptian and Assyrian fables became known to the Greeks in classical times, but no evidence exists to suggest that these influences were either early or important. As far as we can see, therefore, the fable was invented by the Greeks.”

A isto respondeu Williams:

${ }^{3}$ Para um estudo alargado do conceito na antiguidade e terminologia vide Adrados 1999 pp. 3-46. 
"It would be an easy task to refute Handford's naive assertion, provided as we are with such a wealth of ancient Near Eastern fable material in Egyptian and especially in Sumerian and Akkadian, much of it long antedating the Greeks. However, in view of the partial and fragmentary nature of the texts at our disposal, it is not often that we chance upon a fable which can with confidence be regarded as the prototype of one familiar to us from the Aesopic corpus, such as the Akkadian fable of the gnat and the elephant ${ }^{4}$. It is the modest purpose of this paper to trace the history of one Mesopotamian fable through Egyptian and Classical literature to the Middle Ages."

$\mathrm{Na}$ verdade a última afirmação de Williams serve-nos de mote para a nossa simplista - e talvez tão ingénua quanto a conclusão de Handford - sugestão para a compreensão genética da fábula. É do nosso entender que a origem da fábula antiga reside no modelo para a fábula moderna e para Jean La Fontaine, o seu expoente máximo. Ora esse modelo será Fedro, o fabulista latino que emprestou corpo literário e autoria à tradição fabular grega. Esta nossa afirmação assenta num facto simples e incontornável: toda a abordagem literária das antigas tradiçóes fabulares baseia-se em registos expressivos e formais provavelmente desconhecidos nos períodos em que os ensinamentos pela alegoria começaram a circular entre geraçóes e sociedades. ${ }^{5}$

${ }^{4}$ E. Ebeling, Keilschrifttexte aus Assur religiosen Inhalts, vol. 1 (Leipzig 1915-19), p. 317, No. 174, Col. 3, lines 50-54; cf. E. Ebeling, Die babylonische Fabel und ihre Bedeutungffir die Literaturgeschichte [M.AOG, II, 3] (Leipzig 1927) 50.

${ }^{5}$ A propósito da interpretação literária na antiguidade e da representação alegórica vide Kennedy (ed.) 2003 pp.78-90. 
Em verdade, a fábula, enquanto conceito, existe a partir do momento em que começou a ser pensada e questionada em função dos seus aspectos formais e objectivos sapienciais. Nesse sentido, Fedro é o primeiro fabulista a surgir como um cultor da fábula, na medida que é o mais antigo autor a influenciar directamente os cultores da fábula medieval e contemporânea, ainda que outros autores o tenham antecedido. A isso acrescentamos o facto de, num período próximo da produção fabular de Fedro, Teón de Alexandria (c. I d.C.) produzir a frase que nos parece encerrar de forma geral e pouco questionável a ideia conceptual de fábula, seja ela uma fábula presente num texto sumério, seja num documento poético do fabulista latino, Aviano:

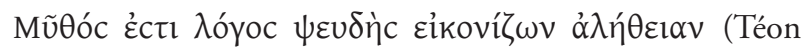
72.28)

"A fábula é uma história inventada ilustrativa da verdade."

A propósito dos Progymnasmata devemos notar a grande relevância que tiveram não só no período Imperial Romano, mas também no decurso da antiguidade tardia e do período medieval. Isto porque compilavam o ensino para os estudantes de retórica, que incluía não só o domínio da gramática e semântica da língua, mas também a discussão sobre a concepção literária e mecânica do discurso (vide Gibson 2008 pp. XVII- XXVI). Dada a relevância da fábula enquanto ferramenta para a Ars Rhetorica, não é de surpreender a sua inclusão nestes manuais, enquanto textos para uso retórico. A propósito, basta que recordemos os exercícios de Libânio com fábulas [cf. Foester 1.1.1-1.3.4 (MṽOor) e Gibson 2008 pp. 1-6]. 
A nossa consideração a propósito de Fedro e da sua validade para a história critica da literatura contemporânea tem presente que não existe nenhum texto que apresente Esopo como o autor inequívoco de um corpus original fechado, sucedendo o mesmo com textos sumérios e acádicos (cf. Gordon 1958). Apenas temos notícia de Esopo como autor tradicional de fábulas. ${ }^{6}$

Isto é, se pretendermos encarar a fábula como algo com uma origem e culto de género, motivados pelo contacto entre culturas, iremos com certeza embater no indecifrável universo que compóe a pré-história e, por conseguinte, ficaremos circunscritos às fontes ocidentais e ao preconceito potenciado pela literatura grega e pela tradição Assíria. ${ }^{7}$ Por outro lado, se aceitarmos a falibilidade das fontes mais antigas, por corresponderem seguramente a uma mínima parte de um corpus textual e oral, e se aceitarmos também o facto da fábula existir antes da sua realização e conceptualização, poderemos tomá-la, no seu espectro global, como um não-género. Todavia, particularizando, é em Fedro que localizamos o género segundo a concepção moderna da fábula. ${ }^{8} \mathrm{Ou}$ seja, o conjunto organizado e estilizado por um autor, que para

${ }^{6}$ Sobre a tradição esópica e a busca por uma autoria lendária vide a dissertação de Jeremy B. Lefkowitz (Lefkowitz 2009).

${ }^{7}$ Bem vistas as coisas, salvaguardando o devido critério analítico de um e de outro, Handford e Williams não têm um ponto de vista objectivamente distinto, apenas um diferente espectro cronológico.

${ }^{8}$ Note-se que é Fedro o primeiro autor, chegado aos dias de hoje, a dotar a fábula de maior sensibilidade literária, além de ter um corpus manifestamente vasto. Porém, sublinhamos que as nossas considerações baseiam-se no facto de Fedro ser anterior a autores como Bábrio e da sua obra ter sido importante no ensino monástico das letras latinas no período medieval, dado que no que refere à expressão literária poderíamos nomear Bábrio da mesma forma que evocamos Fedro. 
além da função didáctica, tem um fundamento artístico na sua materialização.

Todavia, notamos que a recepção destes textos na antiguidade não teria uma equivalência directa ao uso dos nossos dias, ainda que não possamos precisar exactamente a amplitude das suas funçôes. Hoje, a fábula encontra-se dentro de um escrito sapiencial, focado essencialmente na formação do indivíduo, ainda na sua infância. E as suas formas de manifestação e meios onde estas se processam são de uma pluralidade impar em toda a história da literatura. ${ }^{9}$

$\mathrm{Na}$ antiguidade a fábula, mais do que um tipo narrativo', seria um complemento integrante da expressão de outros géneros literários. Tomem-se os exemplos de Hesíodo (Opera vv. 202-212), Ésquilo (Perry 276a, Fr. 139; cf. Radt), Sófocles (Ajax 1142-58), Aristófanes (Aves 474 ss.; Vespas 1401 ss et al), Heródoto (Hist. 1.141; 2.134.3), Xenofonte (Men. 2.7.11), Platão (Alcibiades. 123a, Fédon 60b et al) e Aristóteles (Rh. 2. 20) (cf. Priest 1985 pp. 97-110; vide Adrados 1999 pp. 240-285; Perry 1962 p. XIIIss).

A propósito da definiçấo de género, devemos ainda notar que, apesar das várias questôes que levantam a sua classificação dentro do campo literário, a fábula serve de suporte à definiçáo de outros géneros, também eles de conceptualização problemática, muito por culpa de uma tradição antiga e muitas vezes vinculada a formas de expressão muito próprias e geradoras de preconceitos universais, como sejam os textos bíblicos e a sua intervenção na matriz cultural ocidental.

Por se encaixar na tipologia da narrativa sapiencial, a parábola será um dos mais recorrentes exemplos do uso da

${ }^{9}$ Veja-se como exemplo o estudo de Hibbard (1926) relativo à recepção de Esopo num determinado contexto social. 
analogia com a fábula, de modo a caracterizar-se uma outra forma de expressão, analisável tanto como recurso estilístico retórico, como subgénero literário ${ }^{10}$. De resto, Lessing (Vom dem Wesen der Fabel 1759), um dos pioneiros da discussão académica do género fabular, chega mesmo a tomar a parábola como uma reminiscência da fábula, ainda que as distancie no momento imediato em que a parábola forma o conjunto canónico chegado aos dias de hoje e que tem nos textos do Antigo Testamento o principal veículo de divulgação e até integração na cultura literária ocidental.

Para os antigos, a parábola não seria mais do que a comparação (similitudo) usada como suporte pela retórica do discurso de persuasão (cf. Rh. 2. 20), sendo o discurso forense aquele ao qual seria mais proveitoso tal recurso (cf. Inst. 5. 11). Neste aspecto, existe uma confluência entre as funçóes da parábola e da fábula na antiguidade. Todavia, há que notar que os antigos não analisavam estas manifestaçóes narrativas, enquanto géneros literários, mas apenas como partículas constituintes da retórica. Nesse sentido, lembramos que a arte da persuasão é ela própria um elemento da fábula, passível de ser identificado até como um motor fulcral da acção expressa na fábula moderna de La Fontaine (Cf. Grimm 1992).

É do nosso entender que a associação entre a fábula e a parábola, passível de ser subentendida nos autores antigos ou claramente manifesta na obra de Lessing, apenas permite vincular um aspecto comum a estes géneros: o registo sapiencial. Isto porque, no que toca à sua expressão, são em

${ }^{10}$ Cf. Elm, Dorothee. "Parable (CT).” Brill's New Pauly. Brill Online, 2013. Reference. Universitätsbibliothek der Freien (Univ Berlin). 26 March 2013 <http://www.paulyonline.brill.nl/entries/brill-s-newpauly/ parable-ct-e15200920>. 
absoluto independentes e cumprem funções diferentes na expressão narrativa, ainda que usem ferramentas comuns, como sejam a comparação ou a alegoria.

Esta referência à parábola tem por objectivo notar a importância da fábula no próprio debate epistemológico da história da literatura e também sublinhar a possível subjectividade inerente ao estudo de tradiçóes antigas, servindo-nos para isso da analogia entre géneros. Ainda para mais quando a génese dessas mesmas tradições remonta a um período muito anterior ao registo da escrita e, por consequência, impossível de datar ou localizar no seio de uma cultura. Consideramos ser apenas legítimo julgar tal genética após o momento desse registo e por isso limitamos a sua existência às primeiras culturas letradas (Suméria e Egípcia), que dificilmente podem ser consideradas de forma inequívoca como influências directas na própria tradição ocidental. Isto porque não sabemos até que ponto quer a tradição fabular, quer a tradição do uso da parábola, não existiriam em outras regióes da bacia do Mediterrâneo antes de se ter dado a invenção da escrita.

Porém, apesar desta nossa breve exposição - que não mais pretende do que acender o debate epistémico sobre 'as origens' -, consideraremos apenas no nosso breve estudo a fábula a partir do princípio da recepção de Esopo, isto é, tendo por base as tradições Assírias e ocidentais, no seguimento de um estudo semântico cronologicamente abalizável, como aquele que é feito por R. Adrados (2005). 


\subsection{A FÁBUla gRECO-LATINA:}

A DEFINIÇÃo DE UM GÉNERO E A BUSCA POR UMA TRADIÇÃO

De facto, não será tão problemática a distinção teórica de outros géneros narrativos, como sejam a alegoria ${ }^{11}$ ou parábola, o provérbio, a anedota e o conto fantástico com animais, como será a concretização exacta do modelo conceptual antigo a que supostamente obedece o género que aqui tratamos. A propósito daideia de fábula como pertencente a um grupo específico de textos, é com Demétrio de Fáleron, no final do século IV a.C., que é coligida a primeira colecção conhecida de fábulas gregas. Esta foi composta a partir de citaçóes de autores helénicos que as usavam como exempla (vide Perry 1962). No âmbito da consideração do conceito de exemplum, devemos notar a relevância de tal ferramenta em sociedades altamente politizadas e dependentes do uso da retórica no discursos civil e forense (vide Demoen 1997). ${ }^{12}$ Ao oferecer todo um universo paralelo, explicável por si mesmo e com a apresentação de comportamentos padronizados, as narrativas fabulares são a ferramenta perfeita para o uso da analogia na construção de um argumento.

Esta colecção ou organização de textos tradicionais antigos, promovida por Demétrio, ainda que não corresponda a um levantamento exaustivo e à concretização do género, implica pelo menos uma aceitação de correspondência temática e estilística entre os vários textos. Apesar desta reunião corresponder à aceitação de uma simetria estrutural e funcional dessas fábulas e consequente concepção da ideia

${ }^{11}$ A propósito do registo alegórico grego cf. obra de Heraclito, Allegoriae (= Quaestiones Homericae).

${ }^{12}$ A propósito do aspecto mimético no discurso forense e da transversalidade da fábula no meio retórico e literário vide Kurke 2006. 
de um conjunto pertencente ao mesmo universo, a definição de fábula na antiguidade permaneceu vaga.

Aristóteles é o primeiro autor, cujo trabalho seja conhecido nos dias de hoje, a referir a fábula enquanto uma entidade literária própria ( $R h .2$. 20). Porém, este evoca-a com o propósito de comentar o estudo da retórica e apresenta-a com tendo a função de ferramenta estilística e não tanto como género independente. Os exemplos usados pelo filósofo grego colocam dois oradores (Estesícoro em Hímera e Esopo na ilha de Samos) na circunstância de usarem a fábula para fazerem valer o seu argumento, através do paralelo de circunstância (cf. Jedrkiewicz 1987). De resto, este será o mesmo valor detido nos manuais de retórica de outros autores como Téon de Alexandria ${ }^{13}$, Hermógenes e Aftónio ${ }^{14}$, em que a fábula tem o intuito de chegar à persuasão

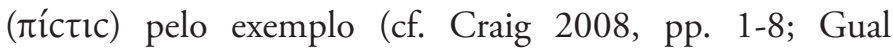
2004, pp. 9-11) - a vertente pedagógica é unanimemente assumida pela recepção da antiguidade, como indissociável do género fabular. ${ }^{15}$ Repare-se que Aristóteles chega mesmo a identificar as fabulas como paradigmas $(\pi \alpha \rho \alpha \delta \varepsilon i ́ \gamma \mu \alpha \tau \alpha)$ de uma realidade, insistindo na função do exemplo de uma realidade ( $R h$. 1393a. 23).

${ }^{13}$ No âmbito dos retóricos antigos, Téon será aquele que, não só mais se dedicou à conceptualização da fábula, mas também que mais se aproximou do princípio analítico moderno (cf. Progymnasmata 72.27 ss).

${ }^{14}$ Weißenberger, Michael (Greifswald). "Aphthonius." Brill's New Pauly. Brill Online, 2013. Reference. Universitätsbibliothek der Freien (Univ Berlin). 27 April 2013 <http://www.paulyonline.brill.nl/entries/ brill-s-new-pauly/aphthonius-e127490>

${ }^{15}$ No âmbito da literatura latina, esta constante presença da fábula no estudo e uso da retórica terá sido alvo de sátira e zombaria, dada a tamanha recorrência, algo que provavelmente denunciaria alguma pobreza de recursos da parte do seu utilizador (vide Marchesi 2005). 


\subsection{A TERMINOLOGIA E CONCEPTUALIZAÇÃo ANTIGAS E A IDENTIDADE DE UM GÉNERO}

A indefinição provocada pela pouca atenção teórica de que gozou na antiguidade, poderá explicar o facto de não existir um termo grego concreto e exclusivo que designe fábula; pelo menos não antes da terminologia latina. Aristóteles identifica-a como $\lambda$ ó $\mathrm{oc}^{16}$, mas existe em outros autores uma certa variação entre este termo e $\mu \tilde{v} \theta o c^{17}$; o próprio Hesíodo introduz a fábula "O falcão e o rouxinol" (Trabalhos e Dias, 202) ${ }^{18}$ usando o termo a ̃uvoc ${ }^{19}$, pelo que poderemos, pelo menos em contexto da Hélade arcaica, colocar uma terceira variável nesta equação léxico-semântica:

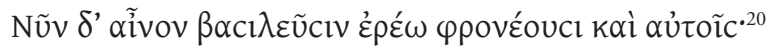

"E agora, vou contar uma fábula aos reis, também eles próprios sábios." (cf. F. 4b)

${ }^{16}$ Trata-se de uma forma nominal do verbo $\lambda \varepsilon ́ \gamma \omega$, podendo significar facto ou ficção, pelo que o seu uso é pouco criterioso.

17 Este termo significa literalmente "palavra ou discurso" e,

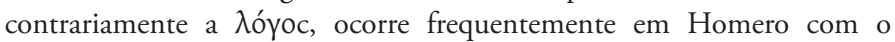
sentido de 'estória'. Cf. Dijk 1997, p. 84-88.

${ }^{18}$ Vide Ferreira 2005. Esta é a mais antiga notícia que nos chega do género fabular em contexto grego. Seguem-se, entre outros os textos de Arquíloco 'a raposa e o macaco' e a 'a águia e a raposa'; e de Simónides 'O escaravelho e a águia'. Vide Irwin 1998.

${ }^{19}$ Note-se a existência de uma relação etimológica com o termo

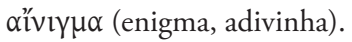

${ }^{20}$ A antiguidade de Hesíodo terá, provavelmente, sido o mote para Quintiliano considerar o poeta Helénico o inventor da fábula em detrimento de Esopo: Illae quoque fabellae quae, etiam si originem non ab Aesopo acceperunt (nam uidetur earum primus auctor Hesiodus), nomine tamen Aesopi maxime celebrantur (Inst. 11.19.1-4). 


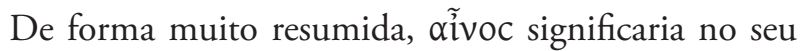
sentido literal 'palavras ditas com um sentido, além daquele que apresentam', como seja o elogio (cf. Dijk 1997, p. 81). De facto, é esse o sentido que tem na Ilíada (XXIII, v. 652 e 795$)^{21}$ e Odisseia (XIV, v. 509), embora essas ocorrências não circunscrevam este termo a esse significado concreto, uma vez que não se resume às oposições homem/animal, representativo/sugestivo, real/ficcional, fábula animal/ provérbio/advinha (cf. Adrados 1999, pp. 5-8). Teócrito (14. 43), por exemplo, usa o termo como significando 'provérbio', tal e qual o entendemos nos dias de hoje. ${ }^{22}$ No entanto, é o termo paroimia ( $\left.\pi \alpha \rho \circ \mu \mu^{\alpha} \alpha\right)$ o mais preciso identificador do conceito de provérbio, pois corresponde ao 'dito popular': uma verdade geral que surge como uma forma de aviso, composto essencialmente por uma única alegoria (cf. $R h$. 1413a, 15-17). ${ }^{23}$ Repare-se que o próprio provérbio foi alvo de debate na antiguidade e sujeito inclusive a criação de colectâneas. ${ }^{24} \mathrm{O}$ próprio Diógenes de Laércio nota esse facto, referindo os paroimia ( $\pi \alpha \rho \circ \iota \mu$ ía, cf. Diog. Laert. 5. 26ss). ${ }^{25}$

${ }^{21} \mathrm{Na}$ Ilíada o seu significado aproxima-se de "palavras de elogio". Cf. Dijk 1998.

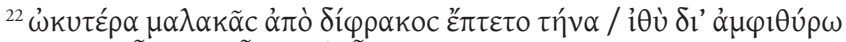

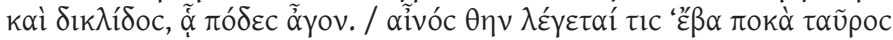

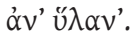

${ }^{23}$ A propósito do provérbio e da sua tradiçáo na cultura ocidental, mais precisamente de matriz judaico-cristâ, vide Erhardt 1953.

${ }^{24}$ Estas colectâneas não são exclusivas da antiguidade grega, sendo que é possível encontrar este tipo de textos na escrita suméria (vide Taylor 2005).

${ }^{25}$ Vide Damschen, Gregor (Halle/Saale). „Paroimia“ Brill's New Pauly. Brill Online, 2013. Reference. Universitätsbibliothek der Freien (Univ Berlin). 25 March 2013 <http://www.paulyonline.brill.nl/entries/brill-snew-pauly/paroimia-e908580> 
Para usarmos de maior precisão, é no período arcaico (sensivelmente compreendido entre os séculos VIII - VI a.C.) que o termo aĩvoc tem maior preponderância na nomeação de um genérico tipo narrativo que incluiria a fábula. E é durante este período que surge a estória assíria

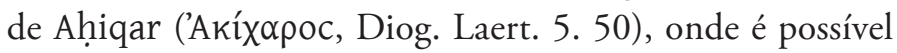
encontrar elementos típicos de um texto designado por aĩvoc. Embora não nos tenha chegado a versão original, sendo a mais antiga correspondente a um papiro do século $\mathrm{V}$ a.C. escrito em aramaico clássico, esta novela foi amplamente divulgada na antiguidade, pelo que the são conhecidas versões em demótico, grego, latim, eslavo eclesiástico antigo, árabe, arménio e siríaco. Este texto, em cuja estrutura e peripécias é possível encontrar bastantes semelhanças com a Vida de Esopo, versa sobre a vida de Ahiqar, um oficial dos reis Sennacherib (Sîn-ahhhēerība) e Asarhaddon (Aššur-ahu-iddina) (c. 704-669 a.C.). Esta personagem, cuja veracidade histórica não está devidamente atestada, terá sido popularizada pela sua sabedoria. E é nas várias circunstâncias em que essa celebrizada sapiência é posta à prova, que as suas estórias e sentenças assumem todo seu potencial no manuseio da retórica e evocação da moral e justiça.

Não nos é possível precisar quando e como aconteceu, mas a verdade é que o termo aĩvoc foi perdendo relevância e acabou por ser substituído na designação de fábula pelos termos ainda mais generalistas e vagos: $\mu \tilde{v} \theta$ oc e $\lambda$ óyoc. A própria discussão do significado específico de cada um dos termos associável ao género fabular faz-se complexa, até porque estes parecem ter variado de significado ao longo do 
tempo e em função do contexto ${ }^{26}$. No entanto, é a língua latina que vai produzir aquele que é o termo identificativo deste género na modernidade: fabula.

É possível que tenha sido o próprio Fedro a consagrar 'fábula' como designação ao referi-la no prólogo às suas Fabulae Asopiae (Pro. 1.1-69). ${ }^{27}$ No que refere à literatura latina, Énio é o primeiro autor de que temos notícia a fazer uso destes textos de carácter gnómico, ao contar a mais antiga fábula escrita em língua latina nas suas Saturae (Sat. vv. $21-58) .{ }^{28}$

$\mathrm{O}$ certo é que este género, ainda que negligenciado no que à reflexão epistemológica diz respeito, foi bastante divulgado na antiguidade e logrou assumir uma nova dimensão na modernidade, com fabulistas como Jean de La Fontaine $^{29}$, Félix María de Samaniego (1781-84), Tomás de Iriarte (1782), Jean-Pierre Claris de Florian (1792), Tommaso Crudeli (1798), Gian Carlo Passeroni (1779-88), Lorenzo Pignotti (1782), Aurelio Bertola de Giorgi (1788), Luigi Fiacchi $(1795,1802,1807)$ e os irmãos Jacob e Wilhelm Grimm. Na verdade, é com os trabalhos dos três primeiros

${ }^{26}$ Podemos inclusive mencionar outras ocorrências que teriam a significação de fábula no contexto em que se inseriam: $\alpha$ $\theta u \rho \mu \alpha$,

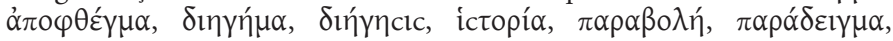

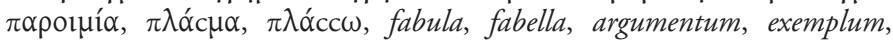
imago, historia, iocus, narratio, neniae, parábola (medieval), sales (neolatino), similitudo (medieval), urbanitates (neo-latino), para além de nomes compostos derivados destes lexemas. vide Dijk 1997, pp. 88-95.

${ }^{27}$ Aesopus auctor quam materiam repperit, /Hanc ego polivi versibus senariis./ Duplex libelli dos est: quod risum movet/ Et quod prudentis vitam consilio monet./ Calumniari si quis autem voluerit,/ Quod arbores loquantur, non tantum ferae, / Fictis iocari nos meminerit fabulis.

${ }^{28}$ Vide notas preliminares.

${ }^{29}$ Note-se que este autor viria a marcar a obra dos autores subsequentes. Sobre a influência da fábula esópica na obra de Jean de La Fontaine vide Bassan 1970. 
que a alegoria animal e o mundo natural se concretizam como recursos elementares na conceptualização moderna da fábula (vide Adrados 1999, pp. 17-21)

\section{a) Estrutura formal e processo narrativo}

O género fabular, que compóe o corpus Aesopica e que projecta as obras de Bábrio, Fedro ou Aviano, ${ }^{30}$ é essencialmente uma composição literária de carácter gnómico, que pretende o ensino prático da moral e das implicaçóes desta no comportamento humano. ${ }^{31}$ No que refere ao aspecto formal, estes textos constroem-se a partir de um relato, geralmente breve, e culminam numa moralidade sentenciosa, por vezes subentendida. ${ }^{32}$

De uma maneira geral a fábula tradicional antiga enquadra um ou mais de três elementos narrativos:

1- Disputa: uma situação provocada pelo conflito de interesses das personagens.

2- Escolha: uma personagem selecciona uma opção

30 Estes autores são tidos como os grandes cultores da fábula do mundo greco-romano, todavia, esse pressuposto baseia-se na conjunto literário que chegou até aos dias de hoje, pelo que não é absolutamente certa a inexistência de outros autores com produçóes consideráveis, mas com menor divulgação. Assinalamos também as noticias que nos chegaram de algumas fábulas de Dositeu (IV d.C.), Libânio (IV d.C.) e Aftónio (IV d.C.), Rómulo (c. IV-V d.C., nome fictício). Sobre estas questóes vide Adrados 1999, 2000, 2003.

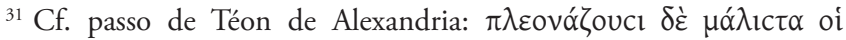

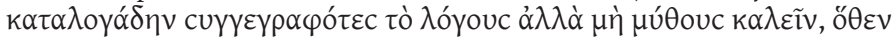

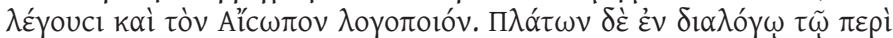

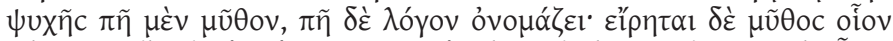
$\lambda$

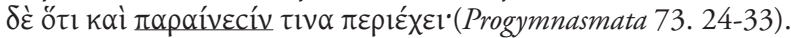

32 Algumas das fábulas, para além da sentença final, podem ter indexadas à narrativa uma outra sentença, proferida ora pelo narrador ora pelas personagens. 
entre as possibilidades apresentadas, advindo daí um determinado resultado.

3- Julgamento ou sentença: a avaliação de um comportamento tipo que se reflicta num resultado positivo ou negativo a quando da sua concretização.

Ora, quando em causa está a acção de um ou mais personagens, a obtenção do sucesso depende do manuseio de determinados atributos seleccionados previamente pela moralidade da fábula: 'a astúcia e sabedoria', 'o poder perante a fraqueza do outro' e 'obediência à justiça moral'. Na verdade, se tentarmos encontrar na fábula uma ideia de sociedade, deparamo-nos com um universo onde são constantes a luta pela sobrevivência, a opressão dos mais fracos pelos mais fortes, a procura pela ascensão social ludibriando o outro e a malvadez como predisposição.

Dentro do contexto greco-latino as versôes escritas mais antigas surgem na poesia iónica e são ainda designadas por ẫvoc (vide supra). E, tal como no restante corpus, a mensagem factual do texto é apresentada de forma clara e integrada numa determinada acção. $\mathrm{Na}$ generalidade das fábulas que compóem a tradição greco-latina, o detalhe da narrativa é em certa medida parco, dada a sua relevância subjectiva para o argumento central. Esse argumento central será o ágon da acção, o único ponto de referência para a analogia (tertium comparationis). Voltamos a notar que é pela analogia que o leitor ou ouvinte converte o conteúdo da acção na mensagem pretendida pelo texto.

b) A mecânica semântica da fábula:

a alegoria e o mundo real

O principio analógico obedece única e exclusivamente à intensão moralizadora da fábula. Isto é, a alegoria realiza-se 
em função dos conceitos abstractos presentes na narrativa. Portanto, toda a imagética e acção funcionam em função da exposição do ensinamento. Está em causa a avaliação de uma determinada conduta, quer seja pelo argumento explicito, com a moralidade final, quer seja de forma indirecta, ao apresentar a consequência, benéfica ou prejudicial, dos actos das personagens intervenientes.

É o intuito didáctico da fábula que define a estrutura textual e baliza os limites da narrativa, por norma, breve. Exactamente pelo carácter curto e pela manifestação imediata de ideias, o argumento faz uso do potencial da imagética do mundo natural, profundamente enraizado nas formas de expressão de cunho popular (vide supra). Isto significa que a fábula greco-latina tem no carácter alegórico o principal elemento identificativo. A alegoria deriva ou da situação que a narração expóe ou das personagens que a integram. ${ }^{33}$ No entanto, é frequente tanto personagens como narrativa corporizarem a alegoria da fábula, sem que exista uma relação dependência semântica entre ambos os elementos da fábula.

A alegoria fabular parte de princípios e características humanas, cujas personagens encarnam e expóem através dos seus próprios signos. Isto é, se a raposa simboliza a astúcia humana, a relação com o animal deve-se à própria astúcia que lhe é reconhecida, ainda que seja de carácter irracional. A esse propósito devemos notar um curioso facto. Apesar de os

${ }^{33}$ A propósito devemos notar a profunda influência da alegoria fabular na execução dos bestiários medievais. Cf. Henderson 1982; para o desenvolvimento deste assunto vide também Hassig 1995, Henderson 1973, http://digital.library.wisc.edu/1711.dl/HistSciTech.Bestiary, e Apostolos-Cappadona, Diane. "Bestiary." Religion Past and Present. Brill Online, 2013. Reference. Universitätsbibliothek der Freien (Univ Berlin). 22 March 2013 <http://www.paulyonline.brill.nl/entries/religion-pastand-present/bestiary-SIM_01878> . 
animais serem dotados de razão, dada a capacidade de falar e entender as situaçóes pelo pensamento abstracto, é frequente

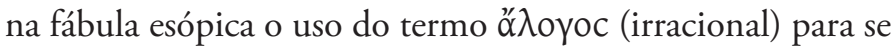
referir ao mundo animal ( $\zeta \omega o ́ v) .{ }^{34}$ Isto significa uma total aceitação do valor alegórico da narrativa, não estando nunca em causa a manifestação de um mundo fantástico e paralelo ao universo humano ou ao universo animal. Ou seja, em nenhum momento a estória narrada tem existência formal por si só, estando dependente da associação ao mundo real e à moralidade deste.

Embora o valor significante que as personagens da fábula detêm seja multifacetado e se revele em função da situação a que são expostas, o símbolo popular do animal não é variável, pelo que não concordamos totalmente com a afirmação algo sentenciosa de Gual: "Los personajes (generalmente animales) no poseen un valor fijo, sino que se hallan sujeitos a una determinada valoración dentro del conflito, definido por su posición y su relación recíproca. Para decidir el éxito de la acción importan sólo los rasgos: la fuerza y la inteligência."(Gual 2004, p. 15). A nossa relutância em aceitar tal consideração reside no facto de o signo animal nas fábulas antigas, chegadas aos nossos dias, não ter representaçóes contraditórias, mas simplesmente apresentar as várias características que o animal adquire aos olhos de uma sabedoria popular (vide por exemplo Tzifopoulos 1995). Ou seja, o animal e o seu símbolo não são portadores de apenas um signo. Na verdade, ainda que em cada fábula o símbolo se faça simples, o conceito da imagética animal que lhe serve de base é tão complexo quanto as noçóes populares acerca do comportamento do animal. De resto, devemos notar

${ }^{34}$ Cf. Fábulas $81,83,107,188$ e 220 
que a alegoria, a metáfora e o símile com base na imagética animal são frequentes na literatura grega, não se cingindo apenas à fábula e ao registo gnómico (vide Adrados 1999, pp. 192-239). ${ }^{35}$

De resto os retóricos antigos sublinham o carácter alegórico da fábula, aleado ao ensinamento, como o seu principal elemento identificativo. A propósito dos retóricos antigos, devemos notar que muitas das fábulas que chegaram até nós foram transmitidas nos seus exercícios de retórica, como sejam os Progymnasmata (vide Adrados 1999, pp. 128-32 e Gangloff 2002). Veja-se como exemplo o comentário de Téon (supra citado). Como a própria definição de 'alegoria' indica, está em causa a apresentação de uma cena distante do mundo real e não enquadrável num determinado contexto cultural. Todavia, representante de uma circunstância transponível para o mundo real. Aqui se distingue a fábula do simples conto fantástico, pois este último pretende sair do universo humano, criando um mundo paralelo não concebível no plano do real, naquilo que à semântica da narrativa diz respeito. A esse propósito, devemos notar que a certa imprecisão que paira sobre a designação moderna e generalizada de 'fábula' nos dias de hoje se deve muito à certa confusão entre os dois modelos narrativos. Isto porque o 'conto de fadas', de carácter infantil, terá tido a fábula antiga como percursora e terá sido potenciado pelo mesmo autor que recuperou o género fabular antigo e o recriou: Jean de La Fontaine. Sucede que La Fontaine expande em alguns dos seus textos a narrativa, relativamente àquilo que seria o padrão antigo. E, da mesma forma, chega a criar situaçóes

${ }^{35}$ A propósito da metáfora na tradição clássica vide também Boys-Stones 2003. 
que não se concretizam unicamente num mundo alegórico, mas sim no mundo fantástico, onde o animal falante não se converte numa metáfora, mas sim num mundo mágico, realizável num imaginário infantil. ${ }^{36}$ Neste ponto, Jean de La Fontaine inova relativamente aos trabalhos de autores anteriores, que normalmente se limitavam à colecção, tradução ou adaptação de fábulas de tradiçóes antigas. É disso exemplo Heinrich Steinhöwel, intitulado de Esopo de Ulm (vide Lenaghan 1968). Ainda que este tivesse publicado os seus textos em 1476, antes da publicação da primeira tradução para língua alemã de fábulas orientais por Anton von Pforr (1480), os seus textos obedeciam integralmente à estrutura tradicional da fábula antiga e tinham grandes similitudes com a obra de Aviano. ${ }^{37}$ Note-se que a obra deste fabulista latino fora um dos primeiros livros impressos em terras germânicas (Der Edelstein 1461). ${ }^{38}$ Já a fábula esópica merece um grande destaque com a publicação de Esopus (1548) pelo monge protestante Burkard Waldis (vide Lieb 2011).

Paralelamente, devemos também notar que na península Itálica tinham sido já desenvolvidas algumas

${ }^{36}$ A esse propósito devemos notar os comentários de Jacques Rousseau (Émile II) relativamente à vertente didáctica das fábulas de La Fontaine. Isto porque no entendimento do filósofo francês aí é ensinado que os mais fortes e astutos são os que logram ter êxito, independentemente da justiça (vide Gual 2009, p. 13).

${ }^{37}$ A poesia didáctica germânica medieval encontrava na fábula esópica um valoroso suporte argumentativo, designando-a por 'bispel', termo correspondente ao exemplum e.g. Der Marner, Bruder Wernher, Reinmar, von Zweter. Vide Infra Dithmar.

${ }^{38}$ Dithmar, Reinhard (Berlin RWG). "Fable (CT).” Brill's New Pauly. Brill Online, 2013. Reference. Universitätsbibliothek der Freien (Univ Berlin). 25 March 2013 <http://www.paulyonline.brill.nl/entries/brill-snew-pauly/fable-ct-e1311520> 
ediçôes e traduções de fábulas antigas (séculos XV e XVI), que podem ter motivado o trabalho do editor Burkard Waldis (vide Manganelli 2012, pp. 20-22). A mais famosa destas edições é a de Bonus Accursius, mais precisamente as duas redacçóes florentinas de 1479/1480 e de $1482 .{ }^{39} \mathrm{~A}$ esta trabalho podemos acrescentar as relevantes redacçóes posteriores de Aldus Manutius (1505), Isaac Nicolaus Neveletus (1610) e Gottfriedus Hauptmann (1741). ${ }^{40}$

Tanto os animais como os objectos animados da fábula posicionam-se num microcosmos humanizado, pelo que estão dotados de razão e fala ( $\lambda$ óyoc). Porém, estes atributos humanos são sempre conjugados com as características originais das criaturas que compóem a narrativa. Por esse motivo, Téon refere-se a uma ficção ( $\psi \varepsilon v \delta \eta ́ c)$ para ascender à verdade $(\dot{\alpha} \lambda \eta \dot{\theta} \theta \varepsilon l \alpha v)$. Daí que um grande conjunto das fábulas termine com um facete dictum (sentença, sententia) iniciada pelo termo oũ $\omega$, que, numa tradução literal, significaria: 'da mesma forma'. Ora, pretende o narrador fazer a ponte entre o mundo extraordinário que apresenta e o mundo dos homens, alvo da sentença. Assim, reforça a espontaneidade da alegoria ao identificar o paralelo com o mundo dos homens. $\mathrm{O}$ mesmo propósito tem a expressão 'ó $\mu \tilde{v} \theta$ os $\delta \eta \lambda$ ỗ (ou ó $\lambda o ́ \gamma o \varsigma ~ \delta \eta \lambda o \tilde{)}$ para evocar o sentido

${ }^{39}$ De notar que em 1448, Rinuccio da Castiglione de Arezzo (Remicius Aretinus) publicava uma tradução da Vita Aesopica e das fábulas esópicas, havendo ainda hoje discussão sobre qual a fonte grega usada na tradução, uma vez que antecedem o trabalho de Acúrcio (vide Perry 1934). Já antes Lorenzo Valla (1439) havia publicado uma versão latina, cuja fonte provavelmente será a mesma.

${ }^{40}$ Note-se que paralelamente havia uma tradição da edição das fábulas esópicas, mas em texto latino. É disso exemplo a edição de Lorenzo Valla de 1439, que serviu de referência para a primeira traduçáo castelhana de fábulas esópicas, publicada por Johan Hurus em 1489. 
alegórico da fábula e fazer a conecção com a realidade dos homens e consequente moral.

\section{c) A sentença, a acçáo e amoralidade}

É importante notar que nem sempre é óbvia a relação entre a sentença e a acção que compóe a fábula. Não é seguro que a fábula e a sentença tenham sido efectivamente produzidas como um texto único - na verdade, tal possibilidade é bastante questionável. O mais verosímil é que ambos tivessem sido construídos como passos independentes e em momentos distintos. Por esse motivo, optámos por distinguir o texto da 'fábula' da 'sentença final', não julgando a fábula como a soma da narrativa com a sentença. $\mathrm{Na}$ grande maioria do corpus que compóe a fábula esópica, a própria narrativa encerra em si um ensinamento sentencioso, pelo que a sentença final apenas o reforça ou, em alguns dos casos, (re)interpreta/adapta (cf. F. 130) e acrescenta informação ao próprio ensinamento da fábula (cf. F. 1, 2, 33). Ora, porque o tema da fábula é, normalmente, de realização imediata e simples, parece-nos questionável a sua conclusão em elementos que não são imediatamente reconhecidos na acção exposta. Daí, poderíamos sugerir que um possível autor pretenderia expandir e completar a informação transmitida pela fábula, a cuja tradição tivesse tido acesso. Desse modo, estaria em causa, da parte do autor, uma complexificaçáo do ensinamento, ainda que este continuasse a acarretar um argumento simples.

Porém, o facto de, no momento da reunião das fábulas, os próprios textos estarem fragmentados e por isso existir a necessidade de serem completados de forma a adequar-se à estrutura dos demais, pode ter motivado a eventual discrepância entre algumas fábulas e as sentenças 
que as acompanham. Por esse motivo, a nossa argumentação, no que toca à independência da sentença e da fábula, pode incorrer num erro, por tomar o corpus que nos chegou como o resultado directo de um precedente original, não corrompido por quem tomou a empresa de reunir tais textos e tradiçóes.

Além disso, devemos acrescentar que o corpus correspondente à fabula esópica não possui ainda uma estrutura absolutamente hermética e invariável, típica nas obras de Fedro, Bábrio e Aviano. Por tal, não é totalmente inconcebível que alguma falta de unidade e clareza fabular dentro do próprio texto se deva à menor capacidade do autor original da fábula. Do mesmo modo, devemos salientar que a estrutura formal e assinatura autoral na fábula não estavam ainda rigidamente padronizadas, algo que de resto é apanágio da poesia. Daí entender-se as estruturas formais mais vincadas nas obras em verso de Bábrio e Aviano.

Enquanto exemplo de alegoria, a fábula caracterizase pelo elemento dramático e pela mecânica que a constrói. A arquitectura da imagem alegórica acaba por expandir o próprio recurso estilístico, pois acrescenta-lhe a possibilidade de subentender uma sentença. As características dos animais ou objectos são por si só elementos de uma determinada moralidade, pelo que não existe apenas a recriação de um mundo humano com personagens animais, mas também uma intercepção entre os vários planos; pois os animais, estando no ambiente alegórico, podem também entrar na realidade do humano. A propósito, lembramos a fábula "As raposas no rio Meandro" (F. 232), onde uma raposa diz ir até à cidade de Mileto.

A fábula antiga é de uma maneira geral um relato curto, parco em explicaçóes e exemplificaçóes, dado o carácter sentencioso a que se propunha. Por tal se fazia imperativa 
a apresentação de imagens que só por si implicassem uma narrativa: os elementos do símbolo animal. Isto é, a apresentação de um imagem com um sentido semântico próprio, que tivesse como fonte uma narrativa anterior que, por exemplo, notasse a astúcia de uma raposa, ou o contexto que faria do lobo um animal do qual se deve desconfiar. Tais informaçóes, muitas vezes registadas no senso-comum, compóem a narrativa que constrói o símbolo. Esta austeridade e ascetismo da exposição atingiram o seu expoente máximo na fábula esópica. ${ }^{41}$

Por norma, a informação que a narrativa contém em si mesma é um argumento moral cerrado e que se explica por meio da metáfora e sugestão de conteúdo. Nesse sentido, e como já referimos, a inclusão das sentenças finais ou conclusões é de uma maneira geral identificável como artificial. $\mathrm{Na}$ verdade, estas conclusôes, na maioria das vezes, iniciadas por ó $\mu \tilde{u} \theta$ oc $\delta \eta \lambda$ ĩ ou ó $\lambda o ́ \gamma o c ~ \delta \eta \lambda$ õ̃ são elementos independentes que poderiam por si só servir o propósito educativo como máximas. $\mathrm{O}$ mesmo se pode dizer do advérbio oű $\tau \omega$, que implica a manifestação da comparação entre o mundo alegórico representando na narrativa antecedente e o mundo humano. Contudo, referindo novamente o ensinamento em causa, como que aclarando a informação da fábula.

Devemos contudo notar a excepção composta por algumas das conclusóes que implicam a identificação do 'destinatário tipo' dos ensinamentos da fábula como sejam

${ }^{41}$ Designamos por 'fábula esópica' o corpus que é atribuído a Esopo, ainda que seja hoje convencional que náo corresponde a um conjunto de textos atribuível a um único autor e a uma época com um contexto histórico específico. Vide Perry 2007, pp. 295-311. 


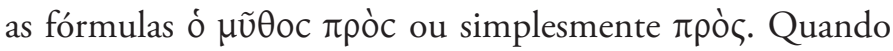
as conclusóes, acompanhadas por estas expressóes, apenas identificam o destinatário sem o contextualizar, o sentido didáctico da sentença acaba por estar ausente, pelo menos de forma independente, uma vez que apenas são compreensíveis quando anexadas à fábula que lhes dá origem. São apenas elementos explicativos, ainda assim artificiais, pois mesmo nestas circunstâncias continuam a ser acréscimos a um ensinamento já encerrado.

\section{d) Função e temática de um género adaptável}

$\mathrm{Na}$ verdade, a simplicidade estrutural da fábula e o próprio ensinamento sentencioso e de senso-comum terão conduzido muito frequentemente à sua identificação como um género de carácter pueril e, portanto, destinada às crianças. Porém, ainda que nos dias de hoje, tendo presente o cânone que compóe o género fabular, não seja totalmente descabida tomar-se essa consideraçáo, no que diz respeito à fábula na antiguidade não é claro que esse fosse um entendimento generalizado. Quando Aristófanes se refere à fábula esópica, tem presente a actividade política da pólis e não o ensinamento de crianças (cf. Vespas 1427ss e F. 63).

A propósito, devemos notar que a fábula acaba por ser dotada de um cunho político não só como ferramenta da oratória grega, mas também enquanto veículo na transmissão de narrativas de temática política. Tomem-se o exemplo dos textos de carácter fabular de Hesíodo (cf. $O p$. 202-11), Arquíloco (cf. IEG fr. 172-81; 185-87), Semónides (IEG fr. 8-9) ou as notícias de Aristóteles a propósito das fábulas que Estesícoro dirigiria contra tiranos de uma cidade siciliana ( $R h .1393 b)$; e também a notícia de Heródoto que dá conta de uma fábula de Ciro da Pérsia dirigida aos Gregos 
(Hist. 1.141). ${ }^{42} \mathrm{Na}$ verdade, esta vertente política da fábula acabou por estender-se ao período moderno, podendo notarse, a título de exemplo, a popularização deste género tanto no discurso como na invectiva politica da literatura inglesa dos finais do século XVII e inícios do século XVIII (vide Hanazaki 1993-1994).

A fábula é de facto um género de carácter político, na medida eu que promove a transmissão de ensinamentos que valorizem o indivíduo e consequentemente a sociedade onde se insere. Talvez por isso se justifique ter sido uma ferramenta tão privilegiada, no âmbito da intervenção pública na pólis, fosse como invectiva política, ${ }^{43}$ fosse como exemplum na exposição retórica.

A ideia generalizada da fábula como literatura infantil poderá também ter por base autores posteriores como Fedro ou Aviano, usados nas escolas monásticas como material para o ensino da gramática e para a transmissão de uma moralidade no comportamento adequado à vida religiosa. De resto, já no século XII, Konrad of Hirsau introduz o uso compulsivo da literatura fabular com quatro objectivos precisos: ensino da leitura; exercícios para a instrução gramática; introdução à sabedoria sentenciosa e guia de conduta para a experiência do indivíduo; introduçấo ao conhecimento das línguas e culturas antigas da matriz europeia. ${ }^{44}$

${ }^{42}$ Repare-se que o próprio Platão faz referência em Alcibiades I à fábula como fonte de argumento (cf. Alc. I 123a 1).

${ }^{43}$ A própria fábula pode carregar a invectiva, seja pela adaptabilidade da sua moral aos diferentes contextos, seja pelo acréscimo exterior e posterior da sentença, aditivo que permite converter a fábula numa referência directa a um dado contexto (cf. F. 243).

${ }^{44}$ Vide Kümmerling-Meibauer, Bettina (Tübingen RWG). „Children`s and Young Adults' Literature (CT). “Brill's New Pauly. Brill Online, 2013. Reference. Universitätsbibliothek der Freien (Univ Berlin). 26 March 2013 
Ora, se à tradição escolar e educativa acrescentarmos a recepção da fábula no século XVII e as colectâneas que se foram reunindo e produzindo nesse período - e que tinham o público infantil como alvo -, intuitivamente compreende-se a conversão que a própria história da literatura fez de um género sapiencial popular em narrativa de instruçáo e entretenimento para crianças (cf. Lyons 1975). ${ }^{45}$

De facto, esta variação de enquadramento de género dentro da cultura literária receptora é um dos motivos pelos quais se pode considerar a fábula como um dos géneros canónicos da literatura, tal qual como o género épico, a tragédia ou mesmo o romance. Isto porque, da mesma forma que os referidos géneros sofrem mutaçóes associadas a correntes literárias, períodos históricos ou inovaçóes artísticas, também a fábula está sujeita a constantes reinvenções. Note-se que no âmbito da literatura, como em qualquer manifestação artística, a criação e género da mesma são organismos vivos, pelo que uma obra pode conceber uma cristalização enquanto objecto final, mas o contexto em que se insere e o órgão maior que compóe (a literatura) continua o processo de adaptação e reinvenção de si mesma e da realidade que constrói pelo somatório de todos os seus constituintes artísticos. Isto é o mesmo texto, não tem que necessariamente cumprir a mesma função ao longo da sua história e, mesmo que a sua interpretação não suscite ambiguidade passível de adequação a um determinado contexto, o seu conteúdo pode em si mesmo conter diferentes funçóes em diferentes períodos

<http://www.paulyonline.brill.nl/entries/brill-s-new-pauly/childrens-andyoung-adultsliterature-ct-e1408880>

${ }^{45}$ Cf. as ediçôes ilustradas: Fables (Paris 1668-1694) de Jean de la Fontaine , Fabeln und Erzählungen (Leipzig 1746-1748) de Christian Fürchtegott Gellert, Basni (St Petersburg 1809) de Ivan Krylov. 
e culturas. Sendo assim, ainda que a fábula esópica não corresponda na sua génese a literatura de carácter infantil, esta pode coerentemente ser usada como literatura didáctica para 'a criança', sem que o sentido que encerra se perca. ${ }^{46}$

${ }^{46} \mathrm{~A}$ propósito da apropriação da fábula pela literatura moderna e da sua redefinição enquanto género infantil vide o estudo de Shu-Jy Duan (1994). 



\section{PARTe II}

A tradiçÃo ESÓPICA 



\section{EsOPO}

Antes de mais, devemos notar que não nos deteremos de forma alongada sobre esta personagem. O principal motivo da nossa disposição será a impossibilidade de relacionar credivelmente a figura de Esopo com o corpus textual que tratamos e cuja tradução aqui publicamos. No que diz respeito ao estudo dos textos, o lendário fabulista é mais uma entidade periférica, cuja importância se regista essencialmente no estudo de uma tradição fabular e da sua lenda (vide Adrados, pp. 271-86). Por tal, iremos ignorar o romance 'Vida de Esopo' como fonte, ainda que alguns dos dados desse texto coincidam com fontes como Heródoto ou Plutarco. A esse facto dever-se-á, muito provavelmente, a existência de uma fonte tradicional comum.

Acerca da vida de Esopo são poucos os dados que nos chegaram e mesmo esses não permitem remover esta personagem do plano ficcional ou lendário. ${ }^{47}$ Ainda que possamos demiti-lo da criação do conjunto de fábulas, que tanto a antiguidade como a modernidade teimaram em atribuir-lhe, não é seguro que este não tenha efectivamente existido, dado o seu nome estar tâo profundamente enraizado na tradição. $\mathrm{Na}$ verdade, podemos comparar a lenda deste cultor da sabedoria popular à tradição de Homero, enquanto autor dos Poemas Homéricos, dada

${ }^{47}$ Para um resumo comparativo entre as várias notícias sobe Esopo vide Chambry 2005, pp. IX-XVIII. 
a vincada subjectividade das notícias relativas à sua existência.

De uma maneira geral, as várias notícias acerca da vida de Esopo parecem concordar que este teria vivido durante o século VI a.C. e teria a sua origem provável na Trácia ou na Frígia $^{48}$. Este último dado oscila em função do autor que o nomeia, como seja Heródoto, Aristófanes, Platão, Aristóteles ou Fedro. No seguimento da obra deste último autor, devemos notar que a relação entre fábula e Esopo está de tal forma vinculada na tradição, que ele próprio é personagem em fábulas de outros fabulistas antigos e chega a ser incluído enquanto tal no corpus da tradição que lhe está associada (cf. F. 8 ou F. 63). Além disso, Fedro refere-se a Esopo no primeiro prólogo às suas Fabulae Aesopiae como criador das fábulas que pretende polir na sua obra. ${ }^{49} \mathrm{E}$, na mesma obra, o fabulista latino nota Esopo como autor, ao identificar um estilo devedor de Esopo:

Librum exarabo tertium Aesopi stilo (Fab. Aes. 3.29)

"Lavrarei um terceiro livro ao estilo de Esopo"

No entanto, devemos salvaguardar um aspecto relevante: a tradição mais antiga não nota Esopo como 'o fabulista', mas sim como um contador de histórias e cultor

${ }^{48}$ Os escravos com estas proveniências eram muito frequentes na antiga Grécia. A razão provável seriam as frequentes incursóes militares neste espaços e as consequentes capturas de habituantes locais. Estas regióes também se caracterizaram por vários períodos de anarquia governativa, o que deixava os seus habitantes desprotegidos e sujeitos ao saque e ao rapto por piratas.

${ }^{49}$ Aesopus auctor quam materiam repperit,/ Hanc ego polivi versibus senariis (1. Prol. 1-2). 
da sabedoria do âmbito popular, baseada na análise do senso comum e empirismo social. A propósito recorde-se o comentário de Sócrates no Fédon de Platão. ${ }^{50}$ Nesse passo o filósofo ateniense nota como Esopo justificaria através de uma estória o conflito/simbiose entre 'o prazer' e a 'a dor', fazendo uso da personificaçấo dos dois conceitos e da intervenção dos deuses na resoluçáo do problema (cf. Dover 1966). De facto, a obra de Platáo trata Esopo como um veículo de um determinado tipo de pensamento que requer a analogia e o exemplum para se justificar.

Como já referimos, Esopo chega a ser personagem de um dos parcos exemplos chegados até aos dias de hoje de romance antigo grego: "Vida de Esopo" (cf. Vita Aesopica, Perry ed.). ${ }^{51}$ Este texto pretende ser uma narrativa da vida do antigo fabulista. Todavia, para além do período tardio (ca. IIIII d.C.), em que as versóes conhecidas deste texto parecem ter sido elaboradas, ${ }^{52}$ a sua indubitável componente ficcional não nos permite usar esses dados para a sugestáo de uma biografia (vide Perry 1933). Muito embora algumas notícias da vida de Esopo presentes na novela sejam coincidentes

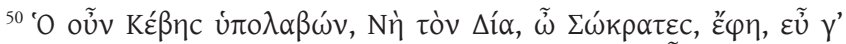

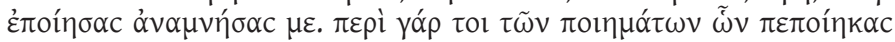

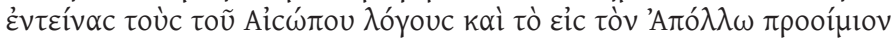

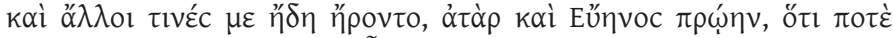

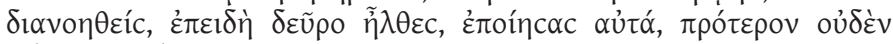

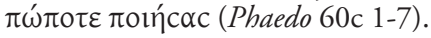

${ }^{51}$ Vide Adrados 1979 e Luzzatto, Maria Jagoda (Florence). "Aesop Romance." Brill's New Pauly. Brill Online, 2013. Reference. Universitätsbibliothek der Freien (Univ Berlin). 25 March 2013 http://www. paulyonline.brill.nl/entries/brill-s-new-pauly/aesop-romance-e110960.

${ }^{52}$ No entanto, salvaguardamos que, pesar das versóes corresponderem a um período tardio, o estilo da narrativa e o próprio cenário em que é colocada, leva a considera-la como uma obra original do período helenístico. 
com as indicaçóes de autores antigos como Xenofonte ou Plutarco - como já foi dito -, ignoraremos este texto como fonte, até porque esta novela carece de uma análise particular à luz de outros conceitos que não a fábula e a sua própria conceptualização.

Ainda que a existência de Esopo seja uma possibilidade credível, não nos é possível distinguir realidade de ficção. A mais antiga notícia sobre o célebre fabulista é-nos legada por Heródoto (Hist. 2. 134). O historiador apresenta-o como criador de fábulas e coloca-o na ilha de Samos, como um escravo frígio servindo Iádmon - tradição que Plutarco segue (vide também $O C D$ Aesop, p. 29). A isto acrescenta que teria compartilhado a escravidão com a hetera Rodópis, amante do irmão de Safo, Carasso. ${ }^{53}$ Este dado apresenta-se interessante para aqueles que pretendem a historicidade desta personagem, independentemente da sua verosimilhança, porque faz por associar duas celebridades na Magna Grécia. De resto, tratase de um tópico comum nas tradições em que se baseiam os autores gregos, que tendem a cruzar personagens relevantes na história da Hélade, como se tivessem uma órbita comum, independente de ser possível atestá-lo como facto; tal sucede até quando não existe coincidência cronológica das suas vidas - o que, à partida, náo seria o caso de Esopo e Safo.

O historiador grego conta ainda que a sua morte seria a expiação de um crime. Este teria sido morto pelos habitantes de Delfos por ter sido acusado, alegadamente de forma injusta, de um roubo sacrílego. ${ }^{54}$ Esta noticia coincide com a

${ }^{53}$ A propósito de Rodópis vide Lidov 2002.

${ }^{54}$ Repare-se que a expressão 'Sangue de Esopo' está atestada em Suda,

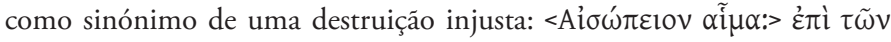


apresentação de Esopo em Aristófanes: contador de fábulas para defender-se das acusaçóes dos Delfos, que o acusavam de ter roubado um vaso do deus ${ }^{55}$ - mais propriamente, o narrador de $O$ escaravelho e a águia. (cf. infra '2.4.3. As colectâneas de Fábulas', referência ao fr. 192 de Calímaco).

Também Platão e Aristóteles aludem à actividade deste fabulista. O primeiro diz no Fédon que, durante os últimos dias de prisão e vida de Sócrates, este tratava de versificar as fábulas de Esopo, das quais era perfeito conhecedor (cf. 60b et al). Aristóteles, seguindo a imagem de entidade política, refere que o fabulista teria participado na assembleia dos Sâmios e aí teria usado da fábula "A raposa e o ouriço".

O certo é que esta personagem lendária se terá imortalizado pelo corpus que se lhe associa, ainda que seja evidente que estes textos não foram produzidos na sua forma original por um único autor. Contudo é possível considerar uma fonte antiga que tivesse reunido um conjunto de fábulas em circulação na oralidade e as tivesse transcrito. Porém, não há provas que confirmem ou contrariem de forma definitiva esta sugestão. A tradição algo lendária acabou de tal forma perdida no tempo, que o próprio Calímaco afirma cantar uma fábula de Esopo num dos seus iambos, não sendo claro se considera que a fábula teria realmente sido criada pelo autor Esopo e, dessa forma, tendo-a recebido através da tradição, a tivesse adaptado; ou se está em causa apenas um topos literário do poeta helenístico (vide infra '2.4.3 As colectâneas de Fábulas', Calímaco Fr. 192).

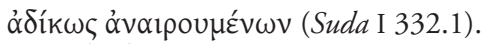

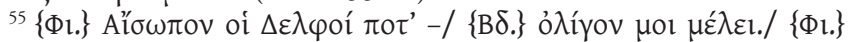

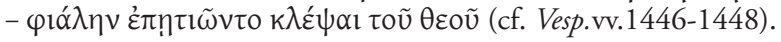





\section{A fábUla ESÓPICA}

Esta é uma designação que teima muitas vezes em não intitular as publicaçóes de traduçôes e de estudos coincidentes com o corpus também por nós tratado. O titulo é preterido em função de 'Fábulas de Esopo', nomenclatura com a qual à partida o leitor mais se identificaria. Ainda que, no nosso entender, tal se deva a um preconceito residente na analogia com autores modernos, como seja La Fontaine, cuja obra - com profundo impacto na cultura ocidental e inspiração para as mais variadas versóes literárias, plásticas, musicais e cinematográficas -, é intitulada tradicionalmente por Fábulas de La Fontaine. Em verdade, este preceito é já bastante antigo, pois a tradiçáo de intitular uma suposta obra de Esopo parece ter em Fedro o seu grande cultor, dado o título da sua obra: Fabulae Aesopiae. E, uma vez que a obra do fabulista latino se encontrava entre as ferramentas do ensino da língua e retórica, nos períodos medieval e moderno, é possível que também a influência essa influência tenha instigado a prática.

A fábula esópica não será mais que a constante recompilação de fábulas que acabaram por resultar em colecções de textos passiveis de serem atribuídos, muito conjecturalmente, a um célebre fabulista de nome Esopo. À partida, esta reuniáo facilitaria a catalogação de textos, que circulavam por via da tradição popular, por citação de autores antigos ou mesmo pela autoria de fabulistas cujos nomes o tempo tratou de apagar da história.

Todavia, reconhecemos que "Fábulas de Esopo" não é uma designação questionável em absoluto, dado que a 
própria "Fábula esópica" pode também ser considerada um título subjectivo e que não faz justiça à verdadeira génese diversa das fábulas que compóe o dito corpus. Resumindo, está em causa a tradição de uma colectânea e não tanto a sua verosimilhança enquanto conjunto literário. E, embora uma determinada nomenclatura se aproxime mais da identificação dessa mesma tradição, não podemos pôr de parte a legitimidade da outra, dado que em última instância estão em causa fábulas atribuídas a Esopo num determinado momento histórico, tenha sido ou não criteriosa essa mesma atribuição.

Como vimos comentando, o mais antigo conjunto de fábulas de que temos notícia (cf. Perry 1962) terá sido coligido por Demétrio de Faléron (ca. 360-280 a.C.), activo político e filósofo na cidade de Atenas ${ }^{56}$. De acordo com a notícia transmitida por Diógenes Laércio (cf. Diog. Laert. 5.80-1). Todos os restantes conjuntos da antiguidade que o sucederam, como sejam as fábulas de Fedro, Bábrio, Aviano, Dositeu ou a tradição de Síntipas, parecem ter tido esta colecção como fonte. ${ }^{57}$ De uma forma bastante resumida, poderemos notar que Demétrio recolheu e prosificou fábulas usadas como exemplos na literatura que lhe era anterior, assim como algumas fábulas que circulassem na oralidade, e apresentou-as como elementos de um conjunto único: Fábula Esópica ou Fábulas de Esopo.

${ }^{56}$ Vide "Demetrius." Brill's New Pauly. Brill Online, 2013. Reference. Universitätsbibliothek der Freien (Univ Berlin). 25 March 2013 http:// www.paulyonline.brill.nl/entries/brill-s-new-pauly/demetriuse 314200.

${ }^{57}$ Dositeu terá um gramático latino que terá vivido no final do século quarto, sendo-lhe atribuída a obra Ars Gramatica. Para a tradiçáo de Síntipas vide Adrados 1999 pp. 132-34. 


\section{ESTRUTURA FORMAL DE UM CONJUNTO E TEMÁTICA}

A tipologia e estrutura das Fábulas Esópicas é de certa forma variada, até pela ausência de uniformidade enquanto criação literária. Tendo em conta os textos das colecçôes Augustana e Vindobonense, poderíamos agrupar as fábulas em função dos tipos seguintes:

- Fábulas de disputa argumentativa (ágon, óyov): duas personagens tentam sobrepor a sua vontade - sendo este o género mais recorrente na Fábula Esópica. Tome-se o exemplo da fábula "O rouxinol e o falcáo" (cf. F. 4a), onde o falcão, analisando as circunstâncias expostas e tendo em consideração a subjectividade do futuro e do imprevisível não-sucedido, rebate o argumento do rouxinol.

- Fábulas de situação: uma determinada personagem é apresentada numa situação e a partir desta são tiradas as conclusôes que servem de fundamento à sentença. Veja-se o exemplo da fábula "O cabreiro e as cabras selvagens" (F. 6), onde o comportamento do cabreiro serve de suporte para a construção da moralidade e consequente sentença. (cf. também F. 7 como paradigma).

- Fábulas etiológicas: a origem de vários elementos universais é explicada, havendo ou não uma moral associada a esta. Dado o seu carácter genesíaco, frequentemente o mito e a religião são o painel de fundo da narrativa. Tome-se como exemplo a fábula 'A águia e o escaravelho' (cf. F. 3). Aí, a explicação de um determinado evento natural, como seja o período de nidificação da águia (cf. F. 3), serve de motor para a exposição de uma determinada moralidade. 
As personagens podem ser homens simplesmente, divindades, pessoas com profissóes ou status social específicos, animais, plantas ${ }^{58}$, objectos, personificaçôes de ideias ou divindades abstractas - Verdade, pudor e vergonha, por exemplo. Todas estas personagens denotam no seu conjunto as características que lhe são atribuídas pela tradição e que as materializa não tanto como personagens tipo, mas como autênticas metáforas ou alegorias (vide supra: imagética animal).

Sublinhamos o facto do corpus constituinte da fábula esópica não corresponder a um conjunto de textos homogéneo no estilo estético, na estrutura formal e no campo semântico. Todavia, nos textos que compóe este conjunto, assim como em textos de autores posteriores como sejam Fedro ou Aviano, verifica-se por vezes uma certa simplicidade das suas estruturas gramaticais. Não está em causa a capacidade do uso da língua, mas o facto dos textos não usarem de uma elasticidade característica da linguagem literária. Isto é, existe uma tendência para a clareza gramatical e fuga às formas irregulares da língua.

Não podemos afirmar seguramente até que ponto é que este ascetismo linguístico estaria presente num corpus escrito anterior e numa possível tradição oral; ou se acaso terá sido consequência da reunião dos textos e da tentativa dos responsáveis pela sua publicação em criar uma linguagem escorreita e facilmente compreensível por qualquer receptor com conhecimento da língua grega. A verdade é que foi este o corpus a que tiveram acesso fabulistas posteriores, o

${ }^{58} \mathrm{~A}$ prepósito da tradição da alegoria vegetal nas fábulas orientais cf. Brumme 1980, Part I\&II e no âmbito da tradição da fábula oriental na literatura grega vide Adrados 1999, pp. 287-366). 
que possivelmente acabou por influenciar também a sua forma de expressão. $\mathrm{O}$ exemplo mais evidente será a obra de Aviano, que terá servido como ferramenta e exemplo em compêndios para o ensino da gramática latina em períodos medievais, dada a clareza e rigidez gramatical. No entanto, a propósito deste último, devemos notar que por escrever num período em que o latim vulgar estava generalizado, a tentativa de Aviano em aproximar a língua do registo clássico pode ter contribuído para a vincada obediência formal ao padronizado latim clássico. 



\section{A fábula esópica ENQUANTO FONTE HISTÓRICA}

Ainda que estes textos, profundamente devedores à tradição popular, sejam parcos em informações que os permitam contextualizar, não raras vezes são-nos sugeridas pistas arqueológicas; sejam simples referências ao conhecimento popular de hábitos de determinados animais, sejam mesmo narrativas inclusivas de personagens históricas. Há no entanto que fazer uma salvaguarda importante: grande parte dos textos foram descontextualizados em função do momento em que são apresentados. Portanto, se a dado momento é referido um certo personagem como Diógenes em "F. 247. Diógenes em viajem", tal não significa que o famoso filósofo cínico fosse originalmente personagem na tradição desta narrativa. Porém, uma vez que a moralidade se adequava à crítica antiga ao movimento cínico, um dos transmissores deste texto poderia perfeitamente, a dada altura, tê-lo usado como ferramenta para atacar este movimento e o seu mais famoso cultor. Note-se o carácter anedótico deste texto (cf. infra n.55)

$\mathrm{Na}$ verdade, este aspecto mutável e manuseável da fábula é uma das principais razóes pelas quais é tão difícil traçar um história verosímil da fábula esópica. De resto, note-se esta simples incongruência: se Esopo fosse realmente o autor deste texto, como poderia ele comentar alguém que, segundo a tradiçấo, vive dois séculos depois de si? Notamos que em nenhum momento está em causa o debate da autoria da obra e que apenas levantamos tal questáo de modo realçar a sujeição da tradição fabular à adaptação e recreio temático. $\mathrm{O}$ 
exemplo de Diógenes é um de entre os vários possíveis, pelo que o apresentamos apenas para realçar que a verosimilhança histórica não pode ser tida em conta na análise dos textos do conjunto que aqui tratamos. ${ }^{59}$

Retomando o ponto inicial, mas mantendo o exemplo, reparamos que existe um dado arqueológico nesta fábula. O texto serve-se do movimento cínico para reprovar um acto imoral, prejudicial para os homens de bem. Ora, tal denota um antagonismo que os seus praticantes gerariam na antiguidade. Ainda que não exista propriamente uma novidade nesta referência, dado que é famosa a desconfiança que os cínicos provocavam nos seus contemporâneos ${ }^{60}$, a noticia desse facto é por si só um dado cultural. Certamente uma informação dada como adquirida na antiguidade, mas que quando recebida reporta um dado período histórico - ainda que largo e impreciso. De resto, não é de todo inverosímil que o próprio Demétrio de Faléron se esteja a manifestar, dado o seu período de vida coincidir com um momento de grande pujança do movimento cínico em Atenas.

Ainda que parca em informação que se expanda para além do objectivo da narrativa, a fábula dá notícias arqueológicas de alguns elementos do quotidiano, mesmo que estes não possam ser necessariamente enquadrados num restrito período histórico. Veja-se o exemplo da fábula "Os cães famintos" (F. 135). Aparentemente, é-nos dada notícia de um tratamento de curtição de peles. Ainda que, do ponto

${ }^{59}$ A fábula 'Démades, o orador (F. 63)' faz-se outro exemplo semelhante, tomando como personagem principal o orador ateniense Démades (350-315 a.C.).

${ }^{60}$ Tome-se o exemplo da crítica aristofânica às actividades politicas dos cínicos no seio da pólis. 
de vista factual, pouco ou nada acrescente sobre o que hoje se sabe acerca da antiguidade, a simples sugestão dessa actividade aproxima a fábula da realidade humana e por esse motivo a torna mais 'reconhecível' quanto ao universo que pretende representar. Está pois em causa uma simples e adquirida manifestação do quotidiano e senso comum de um determinado momento da antiguidade.

Todavia, é na conclusão da fábula (sentença) que o elemento histórico é mais perceptível, uma vez que estas sentenças pretendem por vezes adequar a moralidade da narrativa a um determinado contexto, ainda que esse mesmo contexto seja genérico. Veja-se a fábula "Os lobos e as ovelhas" (F. 153). Este texto nota o perigo de abandonar aqueles que trazem benefício em favor de circunstâncias inseguras. Tendo essa moralidade presente, a sentença final adapta a acção ao contexto político do momento histórico em que o texto é publicado. Nesta fábula é exposto o perigo de uma pólis ser prejudicada pela sua própria negligência para com os seus líderes. Esta é uma indicação genérica, sem referência a uma cidade concreta. Mas bastará recordar o célebre episódio da condenação de Alcibíades aquando da expedição ateniense na Sicília (414 a.C.), para se entender o quâo perceptível seria esta fábula quando usada em contexto de discurso político no seio da pólis grega.

O elemento político é aquele que mais informação cultural transporta, no que diz respeitos às notícias de uma sociedade base para a produção da fábula. Nesse sentido, ao exemplo anterior poderíamos acrescentar a fábula "Os gansos e as garças” (F. 228), em cuja sentença existe novamente uma referência à pólis. A analogia com a narrativa comporta a concepção de uma realidade possível: a fuga de uma cidade sujeita à guerra - em nenhum momento é sugerido um 
conflito interno ou potenciado por um invasor. Também é vincada a informação sobre a distinção entre os pobres e os ricos. Mais uma vez, nada de efectivamente relevante, dada a guerra e a discrepância sociais serem factos comuns nas sociedades antigas - um comentário igualmente extensível a todo e qualquer período da História. Todavia, estas coordenadas criam um fundo social para a produção da sentença. O contexto faz-se um dado histórico, sem que para isso seja necessário um balizamento cronológico ou uma geografia.

De resto, até figuras políticas concretas, como sejam os arcontes, podem ser referidas em função do seu comportamento político (F. 243). E também neste exemplo é a sentença a transportar a informação periférica à narrativa e a adequar a fábula a um dado contexto. Portanto, a fábula dá-nos notícia de uma determinada realidade genérica: uma sociedade politizada e com estruturas funcionais hierarquizadas (cf. F. 26).

A fábula pode também referir uma geografia precisa, como é o caso da referência ao rio Meandro e à cidade de Mileto na fábula "As raposas no rio Meandro"(F. 232). Neste texto a alegoria é montada sobre um cenário concreto e humanizado - a raposa afirma levar uma mensagem para a cidade. A fábula transmite-nos assim dois dados de referência para a sociedade receptora: o sinuoso rio Meandro e a cidade de Mileto.

Da geografia para a medicina, o mesmo pode ser dito da fábula "O doente e o médico" (F. 170). Aí são referidos sintomas de um determinado padecimento e a consequente análise de um médico (i̊c póc) a propósito. Neste caso, uma diagnóstico negligente baseado no aspecto exterior do enfermo. Para além de ser notada a relação médico/paciente, 
há uma constatação da falibilidade da medicina antiga. Mais uma vez, não está em causa uma novidade arqueológica, antes uma referência ao quotidiano e a localização da acção num mundo real. 



\section{As FONTES DA TRADIÇÃO FABULAR ESÓPICA}

\subsection{A reinvençáo da fábula e o debate académico}

Alguns dos dados que fomos notando ao longo deste trabalho parecem descartar a fábula antiga enquanto género literário por si, por aparentemente se converter mais numa ferramenta retórica, como fosse um recurso estilístico ou uma simples narrativa proverbial. $\mathrm{Na}$ verdade, no que toca à discussão teórica, a fábula apenas recebe destaque no século XVIII, apesar da grande popularidade e divulgação de que sempre gozou ao longo da história da literatura. De certa forma, a fábula seria até então um sub-género poético vulgar, usuária de parcos formalismos literários e fundamentada essencialmente na tradição oral e na mecânica didáctica (Cf. Grubmüller 1977). E tal sucede mesmo depois de Jean de La Fontaine ter emprestado à fábula uma novo folgo estético (cf. G'Enetiot 2011 e Scholar 2011) ${ }^{61}$, uma vez que, ao fazer uso de uma peculiar mestria estilística e da musicalidade da linguagem poética logrou ser considerado pela critica de teóricos alemães como Lessing, Herder ou mesmo por J. Grimm (1839) (cf. Ott 1959, Lindner 1977 e Herder 2006). ${ }^{62}$ Já nos primórdios do século XX, outros autores como O. Crusius (1920), W. Wienert (1925) ou K. Meuli (1954),

${ }^{61}$ Sobre a crítica literária de La Fontaine e o impacto do seu registo literário vide Lindner 1977.

${ }^{62}$ Ainda que posteriores, foram também bastante relevantes os estudos de Adolf Jülicher (1888ss), que encontrou na fábula matéria para a análise dos conceitos tradicionais de parábola e de provérbio. Vide supra Dithmar. 
um pouco em função dos trabalhos de Herder e Grimm, debruçaram-se sobre o tema, mas sem oferecer uma definição concreta e até satisfatória, não só no que diz respeito ao género literário, mas também relativamente à relação da fábula com a tradiçâoo (Vide Leibfried 1984 e cf. Perry 1936 e Nøjgaard 1964). Acima de tudo, parece sobressair nestes autores a vontade de catalogar a fábula em função das ferramentas que usa, como sejam a metáfora e a alegoria, juntamente com o seu propósito didáctico. ${ }^{63}$

Contudo, parece-nos forçado que a crítica literária e a reflexão sobre o género fabular se faça de forma a promover uma restrição daquilo que serão os domínios formais da fábula, usando das características presentes, grosso modo, na grande maioria dos textos. Parece-nos que a fábula, enquanto género, prescinde por si só de uma definição enquanto conjunto de narrativas. Nesse sentido, pensar a fábula parecenos fazer-se mais pertinente mediante a busca etiológica e o enquadramento das funçôes didácticas e artísticas que nela são tradicionais. No que refere ao estudo da génese, a análise da origem dependerá sempre de fundamentação antropológica e contextualização cultural; quanto ao segundo ponto, o estudo estará sempre dependente dos textos que nos chegaram e daqueles que vêm sendo criados e reescritos. E por isso, como já comentámos, a análise dos primeiros textos escritos em função do seu contexto, autoria e função, será sempre problemática, caso a arqueologia não amenize a nossa ignorância com novos materiais e notícias.

${ }^{63}$ Cf. Passo de Aristófanes onde se refere/satiriza o carácter sapiencial

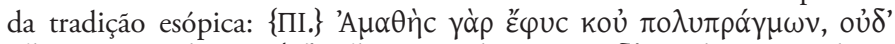

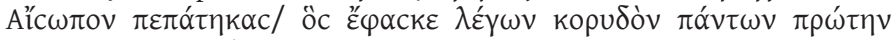

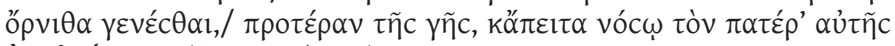

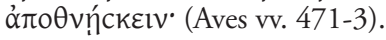




\subsection{Transmissáo do teXto, Fontes antigas}

Ainda que a discussão teórica literária tenha negligenciado a fábula, a tradição grega foi profícua na criação de lendas ou mesmo teorias etiológicas com as 'Fábulas de Esopo' como epicentro de tais ideias. O symposium, enquanto actividade comum a uma elite social, poderá ter tido um papel tão relevante na disseminação da fábula e da temática fabular, quanto o teve a actividade política no seio da pólis (cf. Plut. Mor. 147b). ${ }^{64}$ Notamos que o symposium não implicava necessariamente um convívio fraternal, mas antes uma reunião de carácter social, onde a discussão e debate seriam os pratos principais. Apenas nos é possível sugerir os assuntos aí discutidos, e dependendo sempre da literatura de symposium como fonte, mas filosofia e o estado da pólis seriam os motores propulsores do discurso. Nesse sentido, e dadas as manifestaçôes de sabedoria, é de supor na vertente sentenciosa da fábula um frutífero argumento para os convivas. De resto, esta é uma sugestáo feita na 'Literatura de Banquete', dados os debates protagonizados pelas personagens. Aliás, a própria figura de Esopo chega mesmo a ser referida por Plutarco no seu Banquete dos Sete Sábios (vide Leão 2008).

${ }^{64}$ Vide "Banquet." Brill's New Pauly. Brill Online, 2013. Reference. Universitätsbibliothek der Freien (Univ Berlin). 26 April $2013<$ http:// www.paulyonline.brill.nl/entries/brill-s-new-pauly/banquet-e419290; e “Symposium literature." Brill's New Pauly. Brill Online, 2013. Reference. Universitätsbibliothek der Freien (Univ Berlin). 26 April $2013<$ http:// www.paulyonline.brill.nl/entries/brill-s-new-pauly/symposiumliterature-e1126920> 
A disseminação do imaginário fabular extravasou a simples divulgação através das fábulas escritas ou narrativas de tradição oral. Também a arte plástica foi veículo de divulgação da fábula, não tanto como narrativa, mas como evocação de um determinado texto da tradiçấo. Notamos este aspecto gráfico da fábula não por causa da manifestação artística por si, mas pela figuração de objectos do quotidiano, que vincam a generalização deste género - fosse para evocar uma temática fabular em particular ou simplesmente representar alguns dos principais personagens da fábula (vide exemplo Buchthal 1941). Na antiguidade, assim como nos dias de hoje, seria possível encontrar incrustaçóes dos típicos animais da fábula em selos (escaravelhos, cordeiros, crustáceos, leões, ratos, etc), em emblemas de escudos e até em antigos cunhos de moedas. ${ }^{65} \mathrm{Na}$ própria arquitectura terá havido lugar a este tipo de manifestações, uma vez que Plutarco nota a existência de sapos, palmeiras e cobras de água ( $\check{\delta} \delta \alpha)$ no monumento de Cípselo, tirano de Corinto (c. 657-627 a.C.), em Delfos (cf. Mor. 399s). A propósito, devemos ainda referir a noticia de Aristófanes que satiriza o simbolismo animal no discurso do Oráculo (cf. Paz 1063-86).

Ainda que as possíveis notícias artísticas sejam dados algo dispersos e nem sempre indicativos inequívocos de uma temática fabular, ou pelo menos de influencia da mesma, estas fontes sugerem-nos um fundo cultural de divulgação da imagética animal coincidente com a da fábula, no âmbito da elite grega e onde quer que esta exercesse

${ }^{65}$ Cf. "Fable." Brill's New Pauly. Brill Online, 2013. Reference. Universitätsbibliothek der Freien (UnivBerlin). 25 March $2013<$ http:// www.paulyonline.brill.nl/entries/brill-s-new-pauly/fable-e408170> 
influência ${ }^{66}$. De resto, esta elite não seria exclusivamente política, mas também intelectual. Note-se que Aristófanes estava familiarizado com a tradição fabular e que o próprio Platão apresenta Sócrates vertendo para verso as fábulas de Esopo (cf. Fédon 61a). Não está em causa o real manuseio da fábula por parte destas personagens históricas, mas sim a viabilidade dessa possibilidade. Algo que manifestamente pode ser considerado para o vasto conjunto dos constituintes da pólis ateniense e não só para aqueles que se celebrizaram.

Quer fosse na materialização da figuração em objectos, textos escritos ou na tradição oral, a fábula acompanhava viajantes, políticos e comerciantes nas suas jornadas por um espaço grego cada vez mais largo e consciente da existência de outras culturas com tradiçôes culturais, cuja antiguidade parecia transcender a grega. Talvez por isso, desde pelo menos a primeira metade do século $\mathrm{V}$ a.C., existiria entre os gregos a ideia de que a fábula não teria sido produto original da criatividade do lendário Esopo, dado que são notadas fábulas da Líbia (cf. $\operatorname{Tr} G F$ 139) ${ }^{67}$; Timocréon de Rodes menciona fábulas da Cária e de Chipre (cf. PMG734; 730); Aristófanes sugere uma tradição fabular de Sibáris (cf. Vespas 1258-62); o próprio fabulista grego Bábrio refere a tradição fabular assíria. ${ }^{68}$ Segundo Maria Luzzatto (vide "Fable." Brill's New Pauly), as presumíveis fábulas de Ahiqar ${ }^{69}$ seriam conhecidas $82 a)$.

${ }^{66}$ Cf. as alusôes de Íon de Chios (fr. $38.36 \operatorname{Tr} G F$ ) e de Platão (Phd.

${ }^{67}$ Também o peripatético Camaleão (X $\left.\alpha \mu \alpha \imath \lambda \varepsilon ́ \omega v\right)$ nomeia as fábulas

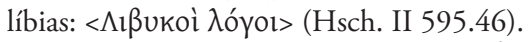

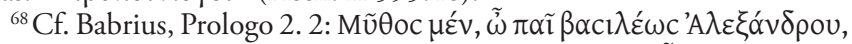

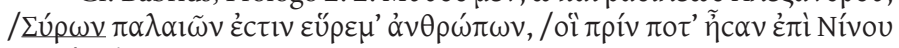

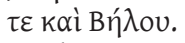

${ }^{69}$ Cf. Müller-Kessler, Christa (Emskirchen). “ Ahiqar.” Brill's New Pauly. Brill Online, 2013. Reference. Universitätsbibliothek der Freien 
na Atenas do século $\mathrm{V}$ a.C. e teriam sido pela primeiras vez coligidas e escritas por Demócrito de Abdera, e mais tarde por Teofrasto.

De resto, é a partir da obra atribuída a Esopo que outros autores teráo produzidos as suas próprias fábulas. Sendo que a tradiçấo que lhe é atribuída é de tal forma antiga e culturalmente transversal, que é possível apenas identificar uma cultura receptora e não uma fonte original.

(Univ Berlin). 25 March 2013 http://www.paulyonline.brill.nl/entries/ brill-s-new-pauly/ahiqar-e109170. A propósito da tradição textual e da narrativa acerca de Ahiqar vide Weigl 2010. 


\section{As colectâneas de Fábulas}

É já do período bizantino a colectânea mais antiga da fábula esópica a chegar até aos dias de hoje. $\mathrm{O}$ conjunto

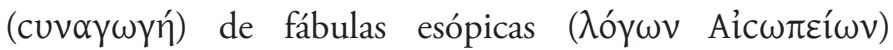
reunido num único livro terá sido compilado pelo peripatético Demétrio de Faléron (c. 300 a.C.) (Cf. Diógenes de Laércio 5.79-81). Ainda que não seja absolutamente seguro que o antigo manuscrito corresponda ipsis verbis à colectânea de Demétrio, o conjunto confirma aquilo que seria já evidente na antiguidade: que as fábulas ali coligidas não eram exclusivamente fábulas de um autor de nome Esopo, mas antes textos do género esópico ( $\alpha i c \omega ́ \pi \varepsilon l o c)$, com as mais variadas origens e tradiçóes como fossem a Líbia, Cária, Síbaris, Lídia, Chipre ou Assíria ${ }^{70}$ (cf. Fedro, 4 Pro. 11-2). Esta é também uma linha partilhada por Téon em Progymnasmata 73. 1-15. Neste passo, sublinhamos a indicação da compilação como obediente a categorias como aquela do tipo 'dito de Esopo ${ }^{71}$. Porém, há que notar que a distância cronológica e geográfica vincaria também uma certa capacidade analítica na antiguidade, dado o difícil acesso a

${ }^{70} \mathrm{O}$ termo grego $\Sigma$ upí $\alpha$, cuja tradução literal corresponderia a Síria, na verdade refere-se à regiáo localizada entre o norte da mesopotâmia e o sudeste da anatólia, ocupada pelo povo de Assur e comumente designada por Assíria. O império assírio ( $\Sigma u ́ \rho o c)$ terá tido um intenso contacto com a cultura grega, principalmente nos séculos VIII e VII a.C.

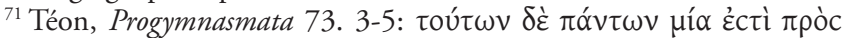

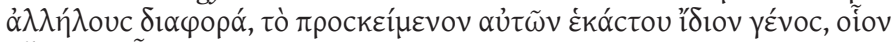

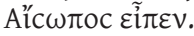


fontes, que por vezes nem sequer existiam. $\mathrm{Na}$ verdade, o potencial assertivo da crítica textual de alguns comentadores antigos, no que a esta colecção se refere, seria possivelmente coincidente ou até mais vincado do que o dos estudiosos dos dias de hoje, dada a mossa maior facilidade em cruzar fontes sobreviventes à passagem do tempo. Ainda assim, aos filólogos actuais é imposta uma pesada e incontornável impossibilidade: a localização cronológica, identificação da autoria e carácter fragmentado e descontextualizado de algumas fontes. Por esse motivo, é sempre potencialmente falível qualquer argumento sentencioso. Nesse sentido, não logramos ajuizar convenientemente quais os critérios particulares que motivaram a criação desta colecção tal e qual a identificamos nos dias de hoje, uma vez que nos faltam dois aspectos essenciais para tal empresa: os comentários do autor original dessa colecção e consequente explicação do método; um corpus de textos que incluísse a estrutura básica de dito popular, fábula, historieta alegórica ou simples sentença, mas que tivesse sido manifestamente excluído na elaboração da antiga colecção.

O facto é que esta colectânea poderá ter sido a base, se não a única fonte, para os escoliastas e estudiosos helenísticos da biblioteca de Alexandria, onde tantos se deslocariam para fazer o seu estudo e provavelmente para obter cópias para as suas próprias bibliotecas, quer fossem privadas, quer propriedade de um estado. Ora, isso por si não chega para explicar os passos em que Calímaco se refere primeiro a Esopo e depois aos ditos líbios. ${ }^{72}$ Não sabemos se o poeta helenístico

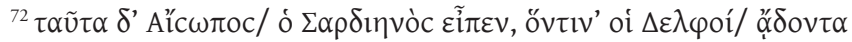

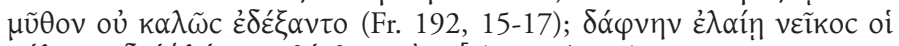

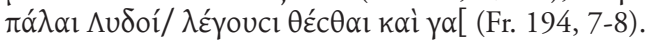


conheceria a obra atribuída a um Esopo, conhecido como original da Lídia, ou se está em causa a identificação da personagem Esopo, independentemente de uma tradição de ditos populares originários dessa região. De notar que no fragmento 192 o poeta helenístico chega a atribuir a Esopo a fábula que canta (cf. Fr. pf 192; POxy 1011). ${ }^{73}$ Nesse mesmo texto, Calímaco dá notícia de dois dados recorrentes na tradição da vida de Esopo:

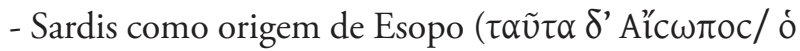

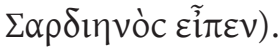

- o episódio da vida de Esopo com o povo de Delfos

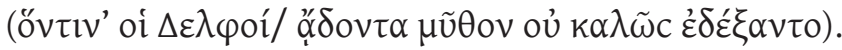

Voltamos a notar que o recurso à fábula foi uma constante nos diferentes registos literários da Grécia antiga. Porém, são provavelmente as fábulas transmitidas em contexto lírico que mais impacto causam na recessão moderna (vide Adrados 1999, pp. 240-70).

Não é clara a existência ou não de várias colectâneas de fábulas devidamente identificadas como obedientes a diferentes tradiçóes. Ainda que exista uma certa coincidência de fontes originais em autores como Fedro, Bábrio e Aviano, é possível encontrar textos que não coincidem com as obras dos mesmos e que não estariam incluídos na colecção de Demétrio. São exemplo algumas fábulas citadas nos exercícios de retórica do período imperial (cf. 16f. de Ps.-Dositeu em Hsr. II pp. 120-9 ou as quarenta fábulas do rector Aftónio em Hsr. II pp. 133-51). Na verdade, a fábula sobre os macacos que encontram uma cidade, mencionada nos Progymnasmata (cf. Ps.-Hermógenes p. 2. 15f) e que é atestada apenas em colecçóes Sírias tardias, indica que também estes textos eram

${ }^{73}$ Vide também Lefkowitz 2009, pp. 83-139. 
usados com propósitos retóricos. ${ }^{74}$ Daqui se advinha que é grande a possibilidade de uma tradição fabular muito mais plural e com um maior corpus escrito do que aquele que nos é possível calcular pelas fontes sobreviventes. Outro exemplo é a fábula "O leão e a cabra", transmitida por Procópio (cf. Procopius, Bella 1.3.13; vide Dijk 1994), já na antiguidade tardia, e que não tem lugar no conjunto de Demétrio (vide Dijk 1994). ${ }^{75}$ Nesse sentido, voltamos a sublinhar a hipótese de um corpus tradicional muito mais vasto do que aquele que nos foi legado, além da provável criação de textos originais, cujos autores a história relegou para o anonimato.

${ }^{74}$ Estas colecçôes, estariam, possivelmente relacionadas com as chamadas 'Fábulas de Sintipas', sobreviventes num edição Bizantina (Cf. CFA II pp. 155-83; Aes. pp. 529-50).

${ }^{75}$ A propósito da ausência de fábulas, cuja circulação na antiguidade está atestada, mas que aparentemente não fez parte da colectânea de Demétrio e por isso não terá chegada até nós através das recensôes da fábula esópica, vide o exemplo explorado por John F. Priest (Priest 1985). 


\section{ESTABELECIMENTO DO TEXTO GREGO E EDIÇÃo DE REFERÊNCIA PARA TRADUÇÁO}

Apesar da possível colectânea de Demétrio ser comummente aceite como a fonte primária para os textos que nos chegaram, os estudiosos actuais não têm como comprovar quais as fábulas que constariam dessa mesma colecção. Ora, esta contrariedade coíbe a assertividade na fixação dos textos, quando existem várias fontes escritas, de diferentes períodos e origens, mas raramente coincidentes no conjunto de fábulas que albergam. Além disso, os textos que se repetem nas várias colecçóes tendencialmente apresentam algumas variantes linguísticas, mais concretamente a escolha do léxico e arranjo verbal; e podem variar na apresentação da sentença final, que de resto é por si só um elemento artificial (vide supra).

$\mathrm{O}$ facto de aparentemente não ter existido uma obra que coligisse todas as fábulas de um real autor e dessa forma as fixasse como regra, no que se refere à estrutura e conteúdo dos texto, potenciou a falta de unidade inequívoca entre os vários manuscritos que nos chegaram. Repare-se que essa ausência de regra terá motivado aquilo que seria uma tendência dos copistas bizantinos que, perante um determinado conjunto de textos e conhecendo a tradição de outros volumes, tinham a tendência para adequar a colecção em causa a uma tradiçấo conhecida, bem como a outros textos com os quais tivessem tido contacto (cf. Perry 1936, p. 73). Ora, esta prática promoveu a corrupção das várias variantes de composiçóes familiares com origem na antiguidade e, em vez de instigar a 
pluralidade da tradição, removeu dos manuscritos o carácter de colectânea da tradição primordial.

Apesar da transformação que os conjuntos possam ter sofrido, é possível identificar quatro recensóes parcialmente independentes e com procedência em diferentes tradiçóes antigas. De uma forma geral e resumida as recensóes, com manuscritos com consequência na catalogação e divulgação da fábula esópica são: ${ }^{76}$

I - A recensão Augustana, cujo nome tem origem no manuscrito Augustanus ou Monacensis 564 (cf. Perry 1936, pp. 77-173; vide Adrados 1999, pp. 60-79), manuscrito em melhor estado de preservação e também o mais célebre desta recensão. $\mathrm{O}$ documento mais antigo desta colecção, o papiro de Rylands 493, terá origem no século V d.C. ${ }^{77}$

II - A colecção tipificada pelo manuscrito Pap. gr. Vindob. 130 (Chambry designa-a em função do manuscrito Canisensis 94, vide 2005, pp. LI-LIV). Também ele célebre, terá constituído fonte para algumas das mais antigas publicações das fábulas de Esopo (cf. Perry 1934 e Perry 1936, pp. 174-203: vide Adrados 1999, 90-3).

III - A colecção Accursiana ou Laurentianus 79, resultante a primeira nomenclatura do nome do seu primeiro editor moderno: Bonus Accursius (cf. Perry 1936, pp. 204228).

IV - A colecção formada pelo conjunto do manuscrito Bodleianus Auct. F. 4 e Palatinus quintus de Nevelet, que na generalidade regista essencialmente a obra de Bábrio (sc. recensio).

${ }^{76}$ Para um comentário mais aprofundado desta matéria, vide Perry 1936 pp. 71-36, cf. Perry 2007 e vide Adrados 1999 pp. 48-140.

${ }_{77}$ Vide estudo em Adrados 1999, pp. 54-9. 
A estas colecções Chambry organiza-as por classes, em função da sua relevância quanto à tradição mais antiga, designando-as por $1^{\text {a }}$ Classe ou P; 2a Classe ou C; $3^{\text {a Classe }}$ ou L; 4a classe ou B. Esta organização é de uma maneira geral seguida por Perry e Ausrath (cf. também Chambry 2005, pp. IX-LIV).

Além destes quatro grupos de manuscritos, usualmente considera-se um quinto, correspondente a um grupo de textos que não denota propriamente a obediência a alguma recensão, antes coligem textos de várias recensões, sem que para isso tenha sido considerado um determinado critério perceptível e inequívoco. ${ }^{78}$ Esta é uma matéria abordada tanto por Perry como Chambry, sendo que é o primeiro o fornecedor dos argumentos para o estabelecimento do corpus da fábula esópica. Todavia, não podemos deixar de notar o trabalho crítico de R. Adrados no comentário aos estudos destes dois filólogos, na monumental obra que nos serve de guia em muitas das consideraçóes sobre o inventário da tradição escrita da fábula esópica e a sua recepção (vide $\mathrm{R}$. Adrados 2003).

A recensão Augustana será a mais antiga e, ao que tudo indica, principal fonte para as restantes. Não nos deteremos em comentários à fixação textual e à catalogação dos textos em função dos manuscritos sobreviventes, pois entendemos não ter base de fundamentação que acrescente algo aos trabalhos de Perry, Chambry e Adrados, ou que de alguma maneira possa tecer uma análise crítica aos mesmos. $\mathrm{Na}$ nossa opinião, para isso seria necessário não só o acesso a

${ }^{78}$ Deste conjunto fazem parte documentos manuscritos como Trivultianis 775 e Vaticanus 777, com origem no séc. XV. 
todas fontes antigas, actualmente em debate, ${ }^{79}$ mas também a descoberta de outras colecçôes ou coincidentes tradiçóes, entre os vários códices e papiros que permanecem sem estudo.

As edições mais commumente seguidas são as de Chambry (2005), Hausrath (1959) e Perry (2007). Ainda que exista uma larga discussão a propósito dos critérios de selecção e correcção dos textos, usualmente a edição de Perry é aquela que mais consenso reúne, enquanto fonte para uma tradução. Isto porque, para além das dificilmente rebatidas opções que toma para o estabelecimento do texto, Ben Edwin Perry abordou a fábula antiga enquanto um corpo único, servindo-se ora de uma fonte, ora de outra, para compor as lacunas provocados pelo tempo em textos desta natureza. Dessa forma, procurou compor conjuntos em função do estilo e estrutura das fábulas, assim como da antiguidade dos manuscritos que nos chegaram. O estudo sistemático da fábula e das fontes antigas que levou a cabo acabou por lhe conferir uma autoridade analítica sobre estes textos, pelo que a edição crítica Aesopica, que contempla toda a tradição fabular da antiguidade, é por excelência a edição de referência para tradutores e estudiosos da Fábula.

Quanto às várias versôes constantes das colecçôes trabalhadas por Perry (vide supra), notamos que o principal método de selecção para a edição Aesopica consistiu no uso da fonte mais antiga, algo que não implica necessariamente maior correcção para com as tradiçôes mais antigas. Porém, está em causa um critério entre outros possíveis e, dado

${ }^{79}$ Para a confrontação entre os vários documentos criticados e avaliados no trabalho destes autores e que servem de base para o corpus que aqui traduzimos, vide tabela comparativa elaborada por Edwin Perry (cf. Perry 1936, pp. 82-145). 
que, não existe um elenco exacto dos textos presentes nas antigas traduçôes, não existe propriamente um critério infalível. Cremos que uma abordagem meramente linguística poderia incorrer em erro da mesma forma, uma vez que as próprios textos têm uma certa conotação artificial. Por esse motivo, torna-se difícil a selecção em função de um critério linguístico.

Hoje a fábula esópica parece ser um género cristalizado, encerrado numa tradição cuja expansão estaria dependente da descoberta de novos materiais. Todavia, continua em circulação nos dias de hoje, seja em ediçôes críticas e traduçóes, seja na rescrita e recepção de um corpus intemporal (cf. Duan 1994), uma vez que não tem uma cronologia de génese nem um fim anunciado. 

As FÁbulas Esópicas 



\section{A Águia e a Raposa (Ch. 3, Hsr. 1)}

Uma águia e uma raposa, tornadas amigas, decidiram viver junto uma da outra, assumindo que a convivência seria a confirmação da amizade.

A águia então subiu a uma árvore muito alta e aí nidificou; a raposa, por seu lado, entrou nuns arbustos, deitou-se e deu à luz. Um dia quando a raposa saiu por comida, a águia, necessitada de alimento, voou para os arbustos, arrebatou as crias e comeu-as, juntamente com os seus filhotes.

Quando, ao regressar, a raposa percebeu o sucedido, não se afligiu tanto com a morte das crias como com a possibilidade de vingança. No entanto, um animal que era terrestre não conseguia perseguir um capaz de voar. Por tal, quedou-se e amaldiçoou o inimigo à distância - a única atitude possível aos mais fracos e incapazes. Ora, aconteceu que, pouco tempo depois, a águia viria a receber o castigo pela impiedade para com a amizade. Pois, quando uns tantos sacrificavam uma cabra do campo, a águia desceu em voo, apanhou uma víscera em chamas do altar e levo-a o ninho. Mas, ao levantar-se forte vento, um pequeno graveto velho e ressequido inflamou-se numa chama brilhante e por causa deste as crias queimaram-se. E uma vez que ainda não voavam, tombaram para o solo. Pois a raposa aproximou-se rapidamente e comeu-as todas à vista da águia.

A fábula mostra que os que violam a amizade, ainda que evitassem a retribuiçấo dos prejudicados por estes serem fracos, não escapam ao castigo do Deus. 


\section{A águia, a gralha e o pastor (Hsr. 2, С}

Uma águia picou em voo de um alto penedo e arrebatou um cordeiro. E uma gralha, ao ver isso, por inveja quis imitá-la. Desceu então com um grande grasnado e lançou-se sobre um carneiro. Mas as garras ficaram presas na lãe, sem possibilidade de levantar voo, batia as asas, até que o pastor, ao aperceber-se do que acontecia, correu a apanhá-la, cortou-lhe as duas asas e, quando a tarde caiu, levou-a para os filhos. E quando estes lhe perguntaram que espécie de ave era, respondeu: "Por aquilo que sei de conhecimento, uma gralha; mas, segundo ela própria prefere, uma águia.”

Da mesma forma, a rivalidade com os mais fortes a nada conduz e, nas desgraças, provoca o ridículo.

\section{A águia e o escaravelho (Hsr. 3, Ch.4) ${ }^{1}$}

Uma águia perseguia uma lebre. Esta, na falta de governantes ${ }^{2}$ que lhe prestassem ajuda, ao ver um escaravelho - o único que a ocasiáo ofereceu -, suplicou-lhe por protecçáo. Então ele, encorajado, quando viu que a águia vinha próxima, propôs-lhe não arrebatar o seu suplicante. E aquela, ao olhar a aparência do minúsculo escaravelho, devorou a lebre. $\mathrm{O}$ escaravelho, furioso para com ela, passou a espiar o ninho da águia e, sempre que ela punha, mal levantava voo, rolava os ovos e partia-os; até que, atormentada em todo o lado, a águia recorreu a Zeus - (pois) é a ave sagrada do deus -

${ }^{1}$ Cf. Comentário Steiner 2012 e a análise da ética exposta no texto.

${ }^{2}$ Optámos traduzir o termo úrápx $\omega v$ por "governantes" dada a carga que o termo teria. Por analogia, muitas fábulas adquirem um certo sentido político. 
e pediu que lhe proporcionasse um lugar seguro para a sua postura. E Zeus concedeu-lhe pôr os ovos no seu regaço; o escaravelho, ao ver isso, fez uma bola de esterco, pôs-se a voar e, quando estava acima do regaço de Zeus, largou-a ali. Então Zeus, na tentativa de sacudir o esterco, levantou-se e sem perceber deixou cair os ovos. Por essa razão se diz que durante o período em que surgem os escaravelhos, as águias não nidificam.

A fábula ensina que não devemos desprezar ninguém, julgando que não existe pessoa tâo fraca que, ultrajada, não seja capaz de se vingar.

\section{A. O rouxinol e o falcão (HsR. 4, CH. 8)}

Um rouxinol, pousado no alto de um carvalho, cantava como era costume. E um falcão, ao vê-lo, como procurasse comida, lançou-se sobre ele e apanhou-o. Então ele, na iminência de ser aniquilado, pediu-lhe para o soltar, dizendo que não era suficiente para encher a barriga de um falcão e que ele devia antes, se procurava alimento, virar-se para as aves maiores. E aconteceu este dizer: "Mas eu seria estúpido, se deixasse a comida que tenha entre mãos e perseguisse o que não me apareceu."3

Da mesma forma, também entre os homens existem insensatos que, por causa da expectativa em maiores recompensas, perdem o que têm entre mãos.

${ }^{3}$ Note-se a existência de uma equivalência temática com a F. 18: “O pescador e o biqueiráo". 


\section{B. O rouxinol e o falcão [VErsão de Hesíodo, Trabalbos e dias (SOLMSEN, Erga VV. 202-13)]}

202 E agora, vou contar uma fábula aos reis, também eles próprios [sábios.

Assim falou o falcão ao rouxinol de pescoço colorido, Enquanto o carregava muito alto, no meio das nuvens, [seguro entre as garras.

205 O rouxinol gemia, infeliz, trespassado pelas garras recurvas. E o outro disse para ele bruscamente:

"Tonto, porque gritas? Agora, segura-te alguém mais forte [do que tu.

Vais para onde eu te levar, por bom cantor que sejas;

Se me apetecer, farei de ti meu jantar ou deixar-te-ei partir. Louco de quem pretende medir-se com os mais fortes; Pois vê-se privado da vitória e à humilhação são adicionados [sofrimentos."

Assim falou o falcão de voo célere, a ave de longas asas.

213 Quanto a ti, Perses ${ }^{4}$, escuta a justiça e não alimentes a insolência que é um flagelo para o homem de inferior condição; e nem

[mesmo o nobre

215 a consegue suportar com facilidade e por ela é esmagado, [ao chegar a ruína.(...)

\section{O deVedor ateniense (HsR. 5, С H. 10)}

Em Atenas, era reclamada pelo credor a conta de um homem devedor. Ao princípio pedia que lhe desse um prazo, argumentando que estava em apuros. Mas como não o convencia, trouxe uma porca para junto daquele - a única que tinha - e oferecia-a para venda. Então, quando

\footnotetext{
${ }^{4}$ Destinatário dos conselhos da obra Trabalhos e Dias (cf. Solmsen).
} 
se aproximou um comprador e perguntou se a porca era fértil, o outro disse que não só paria, como ainda (o fazia) paradoxalmente. Pois, de facto, durante os Mistérios ${ }^{5}$ paria fêmeas e nas Panateneias ${ }^{6}$ machos. Ora, tendo o comprador ficado atónito perante o que fora dito, o credor disse: "não te maravilhes; pois esta parirá cabritos nas Dionisias ${ }^{7 ”}$.

Esta fábula mostra que muitos, por causa do próprio lucro, na verdade, não hesitam em jurar falso coisas impossíveis.

\section{O cabreiro e as cabras selvagens (Hsr. 6, CH. 17)}

Um cabreiro que levou as suas cabras a pastar, quando viu cabras selvagens a misturarem-se com elas, ao fim da tarde, reunindo-as, conduziu-as todas para a sua gruta. Então, no dia seguinte, surgida uma grande tempestade, sem poder levá-las ao pasto habitual, cuidava delas lá dentro e deitava às suas só a porção de comida necessária para não passarem fome, mas para as estranhas amontoava-a em grande quantidade para se apossar delas também.

Ora, passada a tempestade, quando as fez sair todas para o pasto, as selvagens, assim que chegaram ao monte, fugiram. Então, quando o pastor censurava a ingratidão delas, por terem recebido cuidados mais abundantes e o terem deixado, elas, virando-se disseram: "Mas é por isso mesmo que somos cautelosas, pois se a nós - chegadas agora junto de ti - tu honras mais do que as estão contigo desde

${ }^{5}$ Nome ático para o festival do culto de Cora (Perséfone) e Deméter. Vide Brill's New Pauly vol. 9, p.429-33.

${ }^{6}$ Festival religioso.

${ }^{7}$ Festival dedicado ao culto de Dioniso. Vide Brill's New Pauly vol. 4, p.502-3. 
antes, é claro que, se outras se aproximarem depois disto, tu vais preferi-las a nós."

A fábula mostra que não se deve acolher as amizades dos que nos honram mais a nós, recém chegados, do que aos velhos amigos, contando que, quando formos nós os velhos, se fizerem outras amizades, vão preferi-las.

\section{A doninha médica e as galinhas (HsR. 7, CH. 14)}

Uma doninha ${ }^{8}$, ao ouvir que numa quinta umas galinhas estavam doentes, disfarçou-se de médico, agarrou nas ferramentas próprias daquela ciência, apresentou-se ali e, ao deter-se diante da quinta, perguntava-lhes como estavam. Ao que aquelas reagiram: "lindamente!" - disseram - "desde que tu te ponhas a andar daqui."

Da mesma forma, também os perversos não passam despercebidos aos prudentes por muita honestidade que finjam.

\section{Esopo num estaleiro (Hsr. 8, CH. 19)}

Certo dia Esopo, o contador de fábulas, estando ocioso, entrou num estaleiro naval. Como os construtores troçassem dele e o provocassem para dar resposta, Esopo disse que, antigamente, existia o caos e a águas, mas como Zeus queria que o elemento terra emergisse, exortou esta a, por três

${ }^{8} \mathrm{O}$ termo $\alpha$ íloupoc tanto pode corresponder ao gato (felix domesticus), como à doninha. Todavia, considerando a génese da fábula remontar a um momento histórico anterior ao período helenístico, quando o gato se generalizou no espaço da magna Grécia como animal doméstico, será mais assertivo considerarmos a doninha como animal referido neste texto. Isto porque este animal era comum no ambiente doméstico grego desde períodos muito antigos (vide Yannouli 2003), tendo gradualmente perdido importância no âmbito doméstico relativamente ao gato. 
vezes, sorver o mar. Estão a terra, dando início (ao trabalho), primeiro revelou as montanhas; de seguida, ao beber, deixou as planícies visíveis. "Ora, se a terra decidisse beber a água pela terceira vez, o vosso trabalho far-se-ia inútil."

A fábula mostra que aqueles que zombam dos mais capazes, sem dar-se conta, atraem para si as réplicas mais mordazes da parte daqueles.

\section{A raposa e o bode no poço (HsR. 9, CH. 40)}

Uma raposa, ao cair a um poço, ficou ali, retida e incapaz de subir. Ora um bode, fustigado pela sede, quando surgiu junto ao poço, ao reparar nela perguntou-lhe se a água estava boa. Então ela, feliz com a circunstância, estendeuse muito em elogio da água, dizendo-lhe que era boa, e aconselhou-o a descer. Também o bode desceu rapidamente, por ter visto o seu único desejo e, logo que acalmou a sede, procurava com a raposa a melhor subida, e esta disse, ao reflectir sobre a salvação de ambos: "Pois se quiseres apoiar firmemente as patas dianteiras no muro e inclinar os cornos, eu salto apoiada no teu lombo e depois puxo-te para fora." De imediato o bode submeteu-se, complacente pela segunda parte da proposta.

A raposa, subindo pelas suas patas, saltou sobre o lombo e segurando-se nos cornos chegou à boca do poço e saiu. Como o bode a censurava pelo incumprimento do acordo, a raposa voltou-se e disse: "Oh, este! se tivesses tanto tino quantos pêlos tens na barba, não terias descido antes de encontrares uma forma de subir."

Da mesma forma devem também os homens prudentes considerar primeiro o fim dos seus actos e em seguida dessa maneira pô-los em prática. 


\section{A raposa que avistou um leáo (Hsr.10, CH. 42)}

Uma raposa que nunca tinha visto um leão, quando por coincidência o encontrou, como era o primeiro que via, ficou de tal forma perturbada que por pouco não defuntou. Da segunda vez que o encontro aconteceu, ficou aterrorizada, mas não tanto como da primeira vez. E quando o viu pela terceira vez, sentiu tal confiança que se aproximou para falar com ele.

A fábula mostra que o hábito até as mais terríveis das acçóes mitiga.

\section{1a. O pescador Flautista (Hsr. 11, Ch. 24)}

Um pescador, experimentado no uso da flauta', carregou a flauta e as redes, fez-se ao mar e, instalado na saliência de uma rocha, primeiro cantava considerando que, diante da doce melodia, os peixes saltariam por si mesmos. Mas como depois de muito esforço nada conseguiu, largou as flautas, pegou no esparavel, lançou-o à água e apanhou muitos peixes. Já na costa, ao deixá-los cair na rede, como os viu a saltar, disse: "Ó animais estúpidos, pois quando eu tocava a flauta, não dançáveis, mas agora que parei, já o fazeis."

Para os que fazem as coisas fora de tempo, a fábula é oportuna. ${ }^{10}$

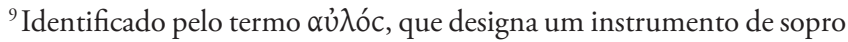
muito popular na antiga Grécia e que era em muitos aspectos semelhante a uma flauta dupla (vide Brill's New Pauly vol. 9, pp 358-60).

${ }^{10}$ Ainda que Perry exclua a sentença final, optámos por incluir na nossa tradução este passo, seguindo excepcionalmente a edição de Hausrath (1970). 


\section{1в. O Pescador flautista (Herod. I, $141 \mathrm{~B}$ ed. Hude = Perry 11A $)^{11}$}

Os Iónios e os Eólios, como os Lídios, mal caíram sob o domínio dos Persas, enviaram emissários a Sardes, diante de Ciro, ofertando-lhe semelhante apoio ao que tinham dado a Creso. E Ciro, quando ouviu o que propunham, contou-lhes uma fábula, dizendo que um tocador de flauta, ao ver peixes no mar, tocava a flauta crente que sairiam por terra, mas como foi frustrado na sua expectativa, agarrou no esparavel, lançou-o e apanhou um grande número de peixes. Ora, ao ver que se agitavam, disse aos peixes: "Parai de dançar para mim, porque quando tocava a flauta, não quisestes sair a dançar."

Ciro contou esta fábula aos Iónios e aos Eólios porque, quando antes, por meio de embaixadores, pediu que retirassem a sua fidelidade a Creso, os Iónios não fizeram caso, mas no momento em que tudo estava feito, estavam dispostos a obedecer a Ciro.

\section{A raposa e o leopardo (Hsr. 12, СH. 37)}

Uma raposa e um leopardo discutiam acerca da beleza. Ao aludir o leopardo um dado momento à variedade das cores do seu corpo, a raposa disse em resposta: "Eu sou mais bela do que tu, pois sou de cores variadas náo quanto ao corpo, mas quanto ao espírito.”

A fábula mostra que o ornamento do pensamento é melhor que a beleza do corpo.

${ }^{11}$ Apesar deste texto ser transmitido por Heródoto, por adequar-se ao género fabular, decidimos traduzir o passo, seguindo a lição de Perry. $\mathrm{O}$ episódio narrado pelo historiador grego diz respeito ao confronto entre Ciro (rei persa) e Creso (rei Lídio). 


\section{Os PESCADORES QUE PESCARAM UMA PEDRA}

(HsR. 13, CH. 23)

Uns pescadores que arrastavam uma rede, como esta estava pesada, rejubilavam e dançavam, acreditando ser grande a pescaria. Mas quando a arrastaram para a praia, como encontrassem poucos peixes e a rede cheia de pedras, ficaram muito tristes. $\mathrm{Na}$ verdade, não se fizeram tão contrariados pelo que aconteceu, mas por terem imaginado o contrário. Então, um deles, que era velho, disse: "mas deixai estar, ó companheiros, pois, como parece, a desilusão é irmã da alegria, e era necessário decepcionarmo-nos depois de nos alegrarmos tanto antecipadamente."

Pois bem, ao ver a mutabilidade da vida, não devemos exultar-nos sempre com as coisas, calculando que, depois da maior tranquilidade, é forçoso que venha a tormenta.

\section{A raposa E O MaCaCo discutiam aCerCa da linhagem (HsR 14, СH. 39)}

Uma raposa e um macaco caminhavam juntos e discutiam acerca da linhagem. E cada um ia expondo com detalhe muitas coisas, até que chegaram junto de um túmulo. Observando-o atentamente, o macaco começou a lamentarse. E quando a raposa perguntou a causa, o macaco apontou os sepulcros e disse: "Mas como não hei-de chorar ao ver as estelas dos meus antepassados, libertos e escravos!” E ela respondeu-lhe: "De qualquer forma mente quanto queiras, pois nenhum se vai erguer para te contradizer."

Dessa forma também os homens mentirosos se gabam sobretudo quando não têm perto quem os possa desmentir. 


\section{A raposa e as uvas (HsR. 15, CH. 32)}

Uma raposa esfomeada, quando viu uvas penduradas de uma ramada, tentou apanhá-las, mas não conseguiu. Então, ao afastar-se, disse para si mesma: "Estão verdes!"

Do mesmo modo, alguns homens que não conseguem concretizar os seus objectivos, acusam as circunstâncias.

\section{A doninha e o galo (Hsr. 16, CH.12)}

Uma doninha, que havia apanhado um galo, queria devorá-lo com um bom pretexto. E aqui, para começar, acusava-o dizendo ser um incómodo para os homens, pois cantava à noite e náo os deixava cair no sono. Mas este replicou que fazia aquilo para benefício deles, pois despertava-os para o hábito dos seus afazeres. Da segunda vez, a doninha disse: "Mas converteste-te num sacrilégio para a natureza, por cobrires as tuas irmãs e a tua mãe". E aquele afirmou fazer isso para benefício do seu amo, pois conseguia que pusessem muitos ovos para eles. Até que aquela, farta, disse: "Mesmo assim, ainda que sempre te forneças de bons argumentos, vou-te comer. ${ }^{12}$

A fábula mostra que a natureza funesta, disposta a fazer dano, ainda que não o consiga por um meio razoável, faz o mal sem disfarce.

\section{A raposa Sem cauda (HsR. 17, CH. 41)}

Uma raposa, que sofrera o corte da cauda por uma armadilha, visto que, devido à vergonha, considerava ter uma vida insuportável, compreendeu que seria necessário

${ }^{12}$ Faça-se um paralelo com a F. 155: "O lobo e o cordeiro" (Hsr. 160, Ch. 221). 
induzir as outras raposas ao mesmo estado, para esconder o próprio defeito com a enfermidade comum. Então, tendo-as convocado a todas, exortava-as a cortar as caudas, alegando que esta não só era inconveniente, mas também as carregava de um peso supérfluo. E uma delas contestou, dizendo: "Olha esta! Mas se isso não te conviesse, não nos aconselhavas tal.”

Esta fábula adapta-se àqueles que dão conselhos aos próximos não por boa vontade mas para obter benefício para si mesmos.

\section{O pescador e o biqueiráo (Hsr. 18, CH. 26)}

Um pescador, tendo lançado a rede, apanhou um biqueirão. Ora, este suplicou para o soltar naquele momento, uma vez que era pequeno; e, mais tarde, quando fosse crescido, colhia-o com maior proveito. $\mathrm{O}$ pescador disse: "Mas eu seria muito tonto, se largasse o proveito em mãos e corresse atrás de expectativas incertas".

A fábula mostra que é preferível tomar o ganho presente, ainda que seja pequeno, do que a esperança, ainda que grande.

\section{A raposa e a silva (Hsr. 19, СH. 31)}

Uma raposa subia a uma ladeira e, quando estava prestes a escorregar, agarrou-se a uma silva. Porém, arranhada na pata, o que a deixou em estado lastimável, acusava a outra, uma vez que havia recorrido a ela e fora presenteada de pior forma. E a silva disse em resposta: "Pois foste enganada pela tua mente, minha cara, ao quereres agarrar-te a mim, eu que tenho o costume de me agarrar a todas as coisas."

Desta forma são tolos os homens que recorrem ao auxílio de quem a natureza inata é fazer o mal. 


\section{A raposa e o crocodilo (Hsr. 20, Сh. 35)}

Uma raposa e um crocodilo discutiam acerca da nobreza. O crocodilo com detalhe falava acerca da glória e dos feitos dos antepassados, e sublinhava que os seus pais tinham sido gimnasiarcas ${ }^{13}$. Ao que a raposa retorquiu: "mas mesmo que não dissesses, pela tua pele nota-se que há muito praticas ginástica."

Da mesma forma, os homens mentirosos têm a reputação dos seus actos.

\section{O pescador E O ATUM (Hsr. 21, CH. 22)}

Uns pescadores que saíram para a faina e que, depois de se fadigarem por muito tempo, não pescaram nada, sentaram-se no barco desapontados. Entretanto, um atum perseguido, que se precipitava com grande estrépito, sem querer saltou para o barco. Entáo, os pescadores capturaramno e, tendo-o levado para a cidade, logo o venderam.

Da mesma forma, muitas vezes o que a técnica não forneceu, a fortuna o concedeu.

\section{A raposa e o lenhador (Hsr. 22, Сh. 34)}

Uma raposa fugia de caçadores e, quando viu um lenhador, suplicou-lhe que a escondesse. Este recomendoulhe que entrasse na sua cabana para se abrigar. Não muito depois, chegaram os caçadores e ao lenhador inquiriram se vira uma raposa a rondar as proximidades. Aquele com a

${ }^{13} \Gamma \varepsilon \gamma \nu \mu \nu \alpha c i \alpha \rho \chi \eta \kappa o ́ \tau \omega v$. Esta forma de particípio prefeito nomeia um oficial do gymnasium. 
voz negava tê-la visto, mas com a mão mostrava onde estava escondida. No entanto, os perseguidores não seguiram as informaçóes que o lenhador indicou, confiantes no que ele dizia.

A raposa, ao perceber que eles se afastavam, saiu e partiu sem fazer barulho. Censurada pelo lenhador, por ter sido solta por ele e náo proferir uma palavra de agradecimento para com ele, a raposa disse: "Eu realmente agradecer-te-ia, se às palavras se assemelhassem os gestos e atitude da mão.”

Com esta fábula se poderia criticar aqueles homens que se declaram sem dúvida virtuosos, mas que através dos seus actos agem de forma perversa.

\section{Os galos e a Perdiz (Hsr. 23, Ch. 21)}

Um homem que tinha galos em casa, quando encontrou uma perdiz amestrada para venda, comprou-a e levou-a para casa para a criar juntamente com os outros. Mas como aqueles a picassem e a perseguissem, a perdiz andava triste considerando que a desprezavam, por ser de outra espécie. Pouco tempo depois, quando viu que os galos lutavam uns com os outros e que não se separavam antes de ambos se ensanguentarem, disse para si mesma: "Mas não mais me entristeço por estes me picarem, pois vejo que nem a eles mesmos se perdoam.”

A fábula mostra que os sensatos aguentam facilmente os excessos dos vizinhos quando vêem que não respeitam os seus próprios parentes. 


\section{A raposa com o ventre inchado (HsR 24, CH. 30)}

Uma raposa faminta, como visse no buraco de uma árvore pão e carne, deixados por um pastor, entrou e comeu-os. Todavia, de barriga inchada e visto não poder sair, pôs-se a chorar e a lamentar-se.

Ao passar por ali outra raposa que escutou os seus gemidos, aproximou-se e perguntou a causa. Quando percebeu o que havia acontecido, disse-lhe: "Pois tens que permanecer aqui até que voltes ao que eras antes de entrar e dessa forma sairás facilmente.”

A fábula mostra que as dificuldades das circunstâncias resolve-as o tempo.

\section{O AlCíone (HsR. 25, CH. 28)}

O alcíone é uma ave solitária que vive permanentemente no mar. Diz-se que, para se proteger das caçadas dos homens, nidifica nos promontórios junto do mar. Uma vez em que estava a ponto de pôr os ovos, chegou a uma escarpa e, quando encontrou uma rocha caída no mar, nidificou aí. Todavia, quando saiu por comida, aconteceu que o mar, revoltado por um vento furioso, foi levantado até ao ninho, tendo-o inundado e afogado a ninhada. Ora, quando o alcíone regressou e compreendeu o que acontecera, disse: "Que desgraçado eu sou, que desconfiado da terra como traiçoeira, me refugiei neste sítio, que se tornou mais traiçoeiro para mim"

Da mesma forma, também alguns homens, ao proteger-se dos inimigos, sem perceberem caem em amigos muito piores do que os seus inimigos. 


\section{UM PESCAdor QUe batia Na ÁGUA (HsR. 26, CH. 27)}

Um pescador pescava no rio. Ao atirar as redes, cortava a corrente de uma margem à outra e, depois de atar uma pedra a uma corda, batia na água, de modo a que os peixes, ao fugir, caíssem indefesos nas redes. Ora, um dos habitantes daquele lugar, ao vê-lo fazer isto, censurou-o por enturvar o rio e, dessa forma, não lhes permitir beber a água limpa. Então, o pescador contestou: "Mas se não agito o rio desta forma, serei forçado a morrer de fome."

Dessa forma, também os demagogos da cidade trabalham melhor no momento em que conduzem a pátria à discórdia. ${ }^{14}$

\section{A raposa e a máscara (Hsr. 27, CH. 43)}

Uma raposa entrou na oficina de um escultor e pôsse a examinar uma por uma as coisas aí existentes, até que descobriu uma máscara de actor trágico. Agarrando-a, disse: "Que cabeça esta, mas não tem cérebro."

A fábula é oportuna para o homem com corpo magnífico, mas de espírito insensato.

\section{O homem aldrabão (HsR. 28, CH. 55)}

Um homem pobre, que estava doente e em mau estado, prometeu aos deuses fazer um sacrifício de cem bois ${ }^{15}$,

${ }^{14} \mathrm{~A}$ inclusão desta sentença poderá indiciar que esta fábula teria sido adequada, a dada altura, à invectiva política e que com essa forma terá prosseguido na tradição. Esta ilação surge na sequência da relação indirecta entre a sentença e o episódio em questão, algo desfasados em sentido.

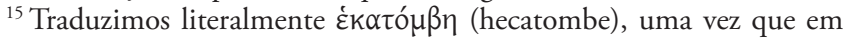
grego este tipo de sacrifício corresponde à junção દ́k $\alpha \tau$ óv $+\beta o \tilde{u} \varsigma(c e m+b o i)$ e essa é uma informação relevante no texto em causa. 
se lhe salvassem a vida. Os deuses, querendo pô-lo à prova, fizeram com que se recompusesse rapidamente. Quando aquele se restabeleceu, uma vez que, em verdade, não possuía cem bois, modelou cem de cebo, queimou-os no altar e disse: "Recebei a promessa, ó deuses!"

Contudo os deuses, desejosos que estavam de, por sua vez, o enganar, enviaram-lhe um sonho que o aconselhava a ir até à praia, pois ali encontraria mil dracmas atenienses. Este ficou contentíssimo e dirigiu-se prontamente para a praia. Então, ali caiu nas máos de piratas que o levaram consigo e, ao ser vendido por eles, encontrou (as tais) mil dracmas. ${ }^{16}$

A fábula é oportuna para o homem intrujão.

\section{O carvoeiro e o pisoador (Hsr. 29, Сh. 56)}

Um carvoeiro trabalhava numa casa e, como visse que um pisoador se estabelecera junto dele, aproximouse e pediu-lhe que fosse viver com ele, argumentando que iriam ter, mutuamente, mais privacidade e que ao habitarem no mesmo sitio viveriam de forma menos dispendiosa. No entanto, aconteceu que o pisoeiro respondeu: "Para mim isso é completamente impossível, pois aquilo que eu branqueasse, tu irias enegrecer."

A fábula mostra que tudo o que é desigual não é associável.

\section{O náufrago e Atena (Hsr. 30, Сh. 53)}

Um ateniense rico navegava com outros passageiros. Então, quando se gerou uma violenta tempestade e o barco se virou, enquanto todos os restantes nadavam, o

${ }^{16}$ Está em causa o preço pago pelo o escravo. 
ateniense, evocando Atena constantemente, fazia imensas promessas, caso fosse salvo. Posto isto, um dos náufragos que nadava próximo disse: "Ainda que Atena te proteja, move os braços.

Em verdade também nós, em vez de pedir ajuda aos deuses, devemos contar com a nossa própria acção.

\section{O HOMEM GRISALHO E AS DUAS PROSTITUTAS (HsR. 31, CH. 52)}

Um homem grisalho tinha duas amantes: uma jovem e outra velha. A mais velha, envergonhada por se relacionar com alguém mais jovem do que ela, quando aquele vinha para junto de si, insistia em arrancar-lhe os cabelos negros. E a mais jovem, dissimulando ter um amante mais velho, arrancava-lhe os cabelos brancos. Dessa forma aconteceu-lhe, ao ser depilado por uma e por outra, ficar calvo.

Da mesma forma, em todas as partes o anómalo é prejudicial.

\section{O Assassino (HsR. 32, СH. 45)}

Um homem que matara alguém era perseguido pelos parentes da vítima. Ao chegar ao rio Nilo, assustou-se com um lobo que foi ao seu encontro, subiu a uma árvore próxima do rio e, ao encontrar-se ali, escondeu-se. Todavia, quando viu uma serpente que subia até ele, atirou-se para o rio e, ao entrar nele, um crocodilo devorou-o.

A fábula mostra que para os homens amaldiçoados não há elemento seguro, nem terra, nem ar, nem água. 


\section{O homem fanfarráo (HsR. 33, С.. 51)}

Um homem praticante de pentatlo, criticado pelos concidadãos pela falta de virilidade, a dada altura partiu da sua terra e quando regressou, muito tempo depois, contava com alarde as muitas proezas que cometera em outras cidades e, ainda, que em Rodes saltara de tal maneira que nenhum vencedor dos jogos Olímpicos alcançara. Também afirmava apresentar como testemunhas os que haviam testemunhado, se alguma vez fossem à cidade. Ora, um dos presentes disse-lhe em resposta: "Mas olha-me este! Se isso é verdade, não é necessário testemunhas para ti, pois aqui é Rodes; ora, venha lá o salto!"

A fábula mostra que, quando é fácil executar a demonstração, todas as palavras sobre isso são supérfluas. ${ }^{17}$

\section{O HOMEM QUE PRoMetia O IMPOSSÍvel (HsR. 34, С . 46)}

Um homem pobre estava enfermo e achava-se muito mal. E, quando a esperança lhe foi tirada pelos médicos, prometia aos deuses fazer uma hecatombe ${ }^{18}$ e também se oferecia para consagrar votos, caso melhorasse. Então a mulher, que estava junto dele, perguntou: "Mas como pagarás isso?" Ele respondeu: "Pois tu crês que me vou restabelecer para que os deuses o exijam de mim?"

A fábula mostra que facilmente os homens fazem promessas que não esperam cumprir na prática.

${ }^{17}$ Repare-se que a sentença mais imediata recairia sobre a mentira e não sobre o acto, pelo que aqui está um caso de uma conclusão que se desvia do sentido moral da fábula. Ainda que a nossa consideração seja criticável, o próprio carácter interpretável da moralidade da fábula revela a artificialidade deste segundo constituinte do texto.

${ }^{18}$ Vide nota à F. 28. 


\section{O HOMEM E O SÁtiro (Hsr. 35, С . 60)}

Conta-se que uma vez um homem fez um pacto de amizade com um sátiro. Contudo, quando chegou o inverno e com ele veio o frio, o homem levava as máos à boca e soprava. Ora, como o sátiro perguntou porque razão fazia aquilo, disse que aquecia as mãos por causa do frio. Mais tarde, quando lhes foi posta a mesa, uma vez que a comida estava muito quente, o homem, agarrando em pequenos pedaços, levavaos à boca e soprava. Como o sátiro perguntasse, novamente, porque o fazia, respondeu que arrefecia a comida, pois estava demasiado quente. Então, o sátiro disse-lhe: "Nesse caso renuncio à tua amizade, meu caro, porque com a mesma boca combates o calor e o frio".

$\mathrm{Na}$ verdade, também devemos evitar a amizade daqueles cuja disposição é ambígua. ${ }^{19}$

\section{O homem manhoso (Hsr. 38, Сн.64)}

Um homem manhoso, que apostou com outro que demonstraria que o oráculo em Delfos mentia, quando chegou o dia combinado, agarrou um pardal entre as mãos e escondendo-o debaixo do manto, foi para o templo e, apresentando-se diante do oráculo, perguntou se o que tinha entre mãos vivia ou era inanimado; na verdade queria, se dissesse "sem vida", mostrar o pardal vivo e, se dissesse "animado", mostrar quando o tivesse sufocado. Mas o deus, tendo percebido a fraude, disse: "Pois basta! $\mathrm{Na}$ verdade, depende de ti se o que tens está morto ou vivo."

A fábula mostra que ao deus é impossível enganar.

${ }^{19}$ Cf. moralidade da fábula 242. "A Hiena e a raposa”. 


\section{O HOMEM CEGO (HsR. 37, СH. 54)}

Um homem cego estava acostumado, pelo toque, a dizer de que espécie era qualquer animal posto entre as suas mãos. Uma vez foi-lhe oferecido um lobacho e, como ficou indeciso ao apalpá-lo, disse: "não sei se és um filhote de lobo ou de raposa, ou um animal como esses. No entanto, percebo claramente que este animal não é o indicado para ir com o rebanho de ovelhas."

Dessa forma, a disposição dos maus é, muitas vezes, revelada pela sua aparência.

\section{O lavrador e O lobo (Hsr. 38, CH. 64)}

Um lavrador desatrelou uma junta de bois e levou-a a beber. Então, um lobo faminto e em busca de comida, quando deparou com o arado, primeiro lambeu o jugo dos bois e depois, aos poucos, inadvertidamente colocou-o ao pescoço e, incapaz de levantar o arado, arrastou-o pela gleba. Quando o lavrador regressou e o viu, disse: "Pois é, desnaturada cabeça, seria bom se, deixando de roubar e fazer o mal, te pusesses a lavrar."

Da mesma forma, os homens malvados, ainda que proclamem honestidade, devido à sua maneira de ser, não recebem o crédito que merecem.

\section{A ANDORinha E os pássaros (HsR. 39, СH. 349)}

Logo que se libertou do visco para apanhar pássaros, a andorinha compreendeu o perigo que representava para as aves e, tendo reunido todos os pássaros, aconselhouos, mais do que tudo, a cortar as árvores de onde nascia o visco ou, se acaso fosse impossível, fugissem para junto 
dos homens e lhes suplicassem que não usassem o poder do visco para as capturar. Ora, os pássaros riram-se dela, como se tivesse dito uma parvoíce, pelo que ela aproximou-se dos homens pedindo-lhes ajuda. E aqueles acolheram-na pela sua sagacidade e receberam-na como vizinha. Dessa forma, aconteceu que os restantes pássaros foram caçados e comidos pelos homens; só a andorinha, assim protegida, nidificou nas suas casas sem preocupaçáo.

A fábula mostra que os que se previnem para o que há de vir, naturalmente, escapam dos perigos.

\section{O AStrónomo ${ }^{20}$ (HsR. 40, СH. 65)}

Um astrónomo tinha o costume de sair todas as noites para observar as estrelas. Certa ocasião, quando circulava pelos arrabaldes com toda a atenção posta no céu, descuidou-se e caiu a um poço. Então, como se lamentava e gritava, alguém que passava ouviu os seus lamentos e, ao aproximar-se para saber o que acontecera, disse-lle: "Meu caro, tu tentas ver o que está no céu e não percebes o que está em terra.”

Esta fábula podia aplicar-se àqueles homens que, jactando-se com a sua fama, são incapazes de gozar das trivialidades da vida.

${ }^{20}$ Esta fábula tem paralelo na anedota transmitida por Platáo (Pl. Theaet. 174a), a propósito da queda de Tales num poço de água. Pode até considerar-se que esta fábula poderá desenvolver o tema cínico dos inconvenientes da ciência (cf. HGLF, Vol. III, p.57. 


\section{A raposa que acaricia UM Cordeirinho E o cáo}

\section{(Hsr. 41 , СН. 36)}

Uma raposa, que se introduziu num rebanho, agarrou um dos cordeiros que ainda mamava e fingia acariciá-lo. Então, um cão perguntou: "Porque fazes isso?" Retorquiu ela: "Tomo conta dele e brinco com ele." E o cão respondeu: "Se não libertas já o cordeirinho, vou dar-te eu as carícias dos cães."

A fábula é oportuna para o homem sem escrúpulos e ladrão estúpido.

\section{O lavrador e os filhos (Hsr. 42, CH. 83)}

Um lavrador que estava às portas da morte desejava que os seus filhos adquirissem experiência de trabalho nos campos, de forma que os chamou e lhes disse: "Filhos, numa das minhas vinhas guardei um tesouro." E eles, depois do pai finar, agarraram nas enxadas e ancinhos e escavaram toda a quinta. Porém, não encontraram nenhum tesouro, mas, em vez disso, a vinha deu uma excelente colheita.

A fábula mostra que o trabalho é um tesouro para os homens.

\section{As râs que Procuravam água (Hsr. 43, CH. 68)}

Duas rãs, cujo charco secara, andavam às voltas à procura de onde ficar. Mas quando chegaram a um poço, uma delas, sem pensar, sugeriu que saltassem. Contudo, a outra disse: "Se acaso a água daqui também seca, como seremos capazes de sair?"

A fábula ensina-nos que não nos devemos envolver nos assuntos levianamente. 


\section{As RÃs EM BuSCA de UM REI (HsR. 44, CH. 66)}

As rãs, afligindo-se por causa da anarquia em que viviam, enviaram a Zeus um embaixador para pedirem que lhes arranjasse um rei. No entanto, Zeus, vendo a sua ingenuidade, atirou para o charco um pau. As rãs, ao princípio, assustadas pelo ruído, enfiaram-se nas profundezas do charco. Em seguida, como o pau estava quieto, emergiram dando mostras de grande desprezo, a ponto de subirem e se instalarem em cima dele.

Então, indignadas com o facto de terem um rei destes, viraram-se novamente para Zeus e pediram a troca por outro governante, pois o primeiro era um grande molengão. Então Zeus, irritando-se com elas, enviou uma cobra de água ${ }^{21}$, que as apanhou e comeu.

A fábula mostra que é melhor ter governantes molengas, mas sem maldade, do que ter governantes perturbadores e perversos.

\section{Os bOIS E O EIXo (HsR. 45, CH. 70)}

Uns bois arrastavam um carro. Mas como o eixo chiava, virando-se para ele disseram: "Olha este! Enquanto puxamos todo o peso, tu chias!”

Assim é com algumas pessoas: enquanto uns se esforçam, os outros fingem trabalhar.

${ }^{21}$ Optámos por traduzir por 'cobra de água' o termo ǔ $\delta \rho c$, de modo a evitar a confusão com o animal mitológico Hidra, uma vez que a mesma palavra pode designar 'cobra de água' ou hidra. 


\section{Bóreas ${ }^{22}$ E Hélios $^{23}$ (Hsr. 46, CH. 73)}

Bóreas e Hélios competiam a propósito da sua força e acordaram conceder a vitória a quem, de entre eles, conseguisse despir um viajante. Bóreas, ao começar, faziase violento; mas como o homem apertasse mais a roupa, Bóreas intensificava-se. Ora o caminhante, sofrendo com o frio, pôs sobre si um manto ainda mais grosso; até que Bóreas, cansado, passou a vez a Hélios. Este, a princípio brilhava moderadamente e, quando o homem tirou a roupa em excesso, aumentou mais a temperatura, a ponto de, não conseguindo suportar mais o calor, o homem se despir e ir banhar-se no rio ali perto.

A fábula mostra que, frequentemente, a persuasão é mais eficaz que o uso da força.

\section{O rapaz que comia as entranhas (Hsr. 47, С . 292)}

Uns que sacrificavam um boi no campo chamaram os vizinhos. Entre estes estava também uma pobre mulher, cujo filho a acompanhava. No decurso do festim, o menino, que se havia empanturrado com tripas e vinho, a dada altura ficou com a barriga cheia e, sentindo-se mal, disse: "Ai mãe, as minhas entranhas!" E a mãe respondeu: "As tuas não, antes as que comeste."

Esta fábula adequa-se ao homem devedor, que disposto a tomar o alheio, quando deve pagar, aborrece-se de tal maneira como se o que entregasse fosse seu. ${ }^{24}$

${ }^{22}$ Divindade figurativa do vento norte.

${ }^{23}$ Divindade figurativa do sol.

${ }^{24}$ Este é mais um caso em que a conclusão parece ter procedido a uma interpretação da fábula (cf. F. 33). 


\section{O RouXinol E O MORCEgo (HsR. 48, С}

Um rouxinol, que estava preso, cantava durante a noite, a partir de uma janela. Um morcego, ao ouvir o seu canto e ao aproximar-se, perguntou-lhe porque razão estava calado de dia e à noite cantava. Então, aquele contou que não fazia isso sem motivo, pois cantava de dia e por isso fora capturado e, desde então, fez-se prudente. E o morcego disse: "Pois não é agora que deves precaver-te, quando já não é vantajoso, mas antes de seres apanhado."

A fábula mostra que, uma vez caído em desgraça, o arrependimento é inútil.

\section{O VAQueIro QUE PERdeU UM BEZERro, E O LEÃo (HsR. 49, СH. 74)}

Um vaqueiro apascentava uma manada de bois e perdeu um bezerro. Ao dar voltas sem o encontrar, rogou a Zeus que, se achasse o ladrão, lhe sacrificaria um cabrito. Então, chegou a um bosque e deparou com um leão que devorava o bezerro. Aterrorizado, levantou as mãos para o céu e disse: "Zeus soberano, antes prometi sacrificar-te um cabrito se encontrasse o ladrão, agora vou sacrificar-te um touro, se escapar das mãos do ladrão.”

Esta fábula podia ensinar, relativamente aos homens caídos em desgraça, que tais pessoas em apuros rogam por encontrar saída, mas ao encontrá-la procuram fugir dela.

\section{A doninha e Afrodite (Hsr. 50, Ch. 76)}

Uma doninha, enamorada de um jovem bem parecido, pediu a Afrodite que a transformasse em mulher. $\mathrm{E}$ a deusa, compadecida pela paixão dela, moldou-a numa bela rapariga e, assim que o jovem a viu, também se apaixonou 
por ela e levou-a para casa. Entretanto, estavam eles no quarto, quando Afrodite, querendo saber se a doninha tendo mudado de corpo também mudava de atitude, largou ali no meio um rato. Ora a doninha, esquecendo o que era naquele momento, levantou-se do leito matrimonial e perseguiu o rato com intensão de o comer. Então a deusa, irritada com ela, devolveu-a à antiga natureza.

Dessa forma, também os homens maus por natureza, mesmo que mudem de estado, ainda assim, não mutam o carácter.

\section{O lavrador e a Serpente (Hsr. 51, Ch. 81)}

O filho de um lavrador, matou-o uma serpente, que rastejava por ali. Ora, sofrendo ele terrivelmente com isso, agarrou num machado e foi pôr-se junto da toca dela à espera, para que, logo que saísse, de imediato a atacar. Então, quando a serpente pôs a cabeça de fora, vibrou o machado, mas falhou totalmente e partiu em duas uma pedra que ali estava. E, alarmado pelo que viria a seguir, propôs-lhe que se reconciliasse com ele. Mas a serpente disse: "É que nem eu posso estar em paz contigo vendo a pedra partida, nem tu comigo ao contemplares o túmulo do teu filho."

A fábula mostra que os grandes ódios não têm fácil resolução.

\section{O lavrador e os CẤes (Hsr. 52, CH. 80)}

Um lavrador estava encerrado na sua granja por causa do mau tempo e, uma vez que não podia sequer sair para procurar comida para si, primeiro comeu as ovelhas. Depois, como o mau tempo persistia, alimentou-se também das cabras. De seguida, em terceiro lugar, como não amainava (a 
tormenta), virou-se para os bois da lavoura. Ora os cães, ao verem o que fazia, disseram entre si: "Temos que sair daqui, pois o dono, se não poupou os bois de lavoura - companheiros de trabalho -, porque razão nos haveria de poupar?"

A fábula ensina que nos devemos preservar, principalmente, de quem nem sequer se abstém de fazer mal aos da sua casa.

\section{OS FILHOS DO LAVRADOR QUE DISCUTIAM (Hsr. 53, СH. 86)}

Os filhos de um lavrador discutiam. Todavia, aquele, apesar dos muitos conselhos, como náo era capaz de, pela palavra, os persuadir a mudar de disposição, percebeu que havia de o conseguir pela prática e exortou-os arranjar um conjunto de varas. Ora, quando fizeram o que fora pedido, primeiro entregou-lhes as varas num molhe e pediu-lhes para as partirem. Contudo, ainda que se esforçassem, não eram capazes; de seguida, desfez o conjunto e deu-lhes as varas uma a uma. E como as partiam facilmente, disse: "Pois bem, meus filhos, se vós estiverdes em harmonia, sereis imbatíveis para os vossos inimigos, mas se discutirdes, sereis fáceis de bater.

A fábula mostra que tão forte é a concórdia, como fácil de vencer é a discórdia.

\section{Os caracóIs (HsR. 54, CH. 173)}

O filho de um lavrador que grelhava uns caracóis, ao ouvi-los crepitar, disse: "Animais estúpidos, as vossas casas estão em chamas e ainda cantais?"

A fábula mostra que tudo o que se faça fora do tempo é reprovável. 


\section{A mulher e os escravos (Hsr. 55, С . 89)}

Uma viúva trabalhadora tinha umas criadas e costumava acordá-las durante a noite para trabalhar ao cantar do galo. Então elas, sempre cansadas, decidiram que deviam degolar o galo lá de casa, pois suspeitavam que ele era a causa dos seus males, por acordar a patroa à noite.

Porém, aconteceu que, tendo feito isso, caíram numa situação mais penosa, uma vez que a patroa, desconhecendo a hora do galo, acordava-as ainda mais cedo.

Da mesma forma, para muitas pessoas, os seus próprios desígnios são a causa dos males.

\section{A brUXa (Hsr. 56, Сh. 91)}

Uma bruxa, que fazia conjuros e remédios para aplacar a cólera dos deuses, ganhava bem a vida. Por causa disso, alguns acusavam-na de trazer mudanças de comportamento para com os deuses e levaram-na a julgamento. Entấo, aqueles que a acusavam, condenaram-na à morte. Ora, um que a vira ser levada perante o tribunal, disse: "Pois é, tu que desviavas a cólera dos deuses, como não foste capaz de persuadir os homens?"

Esta fábula aplica-se à mulher charlatá que, prometendo fazer maravilhas, mostra-se incapaz de levar a cabo as coisas triviais.

\section{A velHa E O Médico (HsR. 57, Сh. 87)}

Uma mulher velha, que estava doente dos olhos, mandou chamar um médico a soldo. Este, sempre que a visitava, aplicava-lhe unguento sobre os olhos, enquanto ia subtraindo, um a um, os seus pertences. Ora, já depois de 
lhe ter levado tudo e a ter curado, pediu-lhe o pagamento acordado. Mas como ela não quisesse pagar, levou-a até aos magistrados. Porém, ela dizia que lhe prometera o salário, caso ele lhe curasse a visão, mas que agora estava pior do que antes da cura, "Pois nessa altura", dizia "via todos os utensílios da minha casa, no entanto, agora não sou capaz de ver nenhum."

Assim, os homens malvados, por ambição e sem se darem conta, demonstram a sua culpa.

\section{A mulher e a galinha (Hsr. 58, Сн. 90)}

Uma mulher viúva dona de uma galinha que punha um ovo em cada dia, pensou que se lhe desse mais comida poria dois ovos por dia. Ora, quando fez isso mesmo, aconteceu que a galinha se fez gorda e já não punha uma vez que fosse.

A fábula mostra que muitas pessoas, por ganância de obter mais, perdem o que possuem.

\section{A doninha e a lima (Hsr. 59, С . 77)}

Uma doninha que se enfiou na oficina de um ferreiro pôs-se a lamber uma lima que ali havia. Entâo, aconteceu que, ao arranhar a língua, começou a verter muito sangue. A doninha alegrava-se pensando obter algo do ferro, até que perdeu a língua definitivamente.

A fábula dirige-se àqueles que, pelo seu amor às disputas, se prejudicam a si mesmos. 


\section{O velho E A MORTe (HsR. 60, СH. 78)}

A dada altura, um velho que ia cortar lenha, carregado com ela, percorria um longo caminho e, quando pousou o peso, cansado que estava, chamou pela morte. Ora, como a morte aparecesse e lhe perguntasse porque a chamava, o velho disse: "Para que leves a carga."

A fábula mostra que o homem deseja a vida, ainda que seja miserável.

\section{Um lavrador e a Fortuna (HsR. 61, CH. 84)}

Um lavrador que encontrou um tesouro ao cavar a terra oferecia a cada dia coroas à terra, como tivesse sido favorecido por ela. Todavia, a fortuna apareceu e disse: "Mas porque atribuis à terra os meus presentes, dados por mim, quando desejava enriquecer-te? Pois se a situação mudasse a sua natureza e se consumisse em penosas necessidades, não culparias a terra, mas a fortuna.”

A fábula ensina-nos que é necessário conhecer o bemfeitor e dar-lhe as graças.

\section{Os golfinhos E o goliáo (HsR. 73, СH. 95)}

Os golfinhos e as baleias guerreavam entre si. Como o combate se fazia cada vez mais violento, um golião emergiu e tentou apaziguá-los. Porém, um dos golfinhos, interrompendo, disse-lhe: "Mas é-nos mais suportável morrer lutando entre nós, a ter-te como mediador."

Dessa forma, alguns homens sem valor, quando caem num tumulto, julgam ser alguém. 


\section{DÉmades ${ }^{25}$, O ORAdor (HsR. 63, CH. 96)}

Démades, o orador, a dada altura falava ao povo de Atenas, mas como os atenienses não prestavam muita atenção, pediu que lhe permitissem contar uma fábula de Esopo. Então, tendo eles assentido, começou por dizer: "Deméter, uma andorinha e uma enguia seguiam pelo mesmo caminho. Ora, tendo elas chegado à beira de um rio, a andorinha levantou voo e a enguia mergulhou...” E, dito isto, calou-se, pelo que lhe perguntaram: "E Deméter, o que fez?" Aquele respondeu: "Ficou furiosa convosco, que abandonais os assuntos da cidade e ficais presos às fábulas de Esopo."

Da mesma forma, também são insensatos os homens que desprezam o que é necessário e preferem sobretudo o prazer.

\section{O HOMEM MORDIDO POR UM CÁO (HSR. 64, СH. 177)}

Um certo homem, mordido por um cáo, andava por todo o lado à procura de quem o curasse. Então, como alguém lhe dissera que devia limpar o sangue com um pedaço de pão e atirá-lo ao cão que o mordera, respondeu: "Mas se eu faço isso, todos os cães da cidade me vão morder."

Da mesma forma, a maldade dos homens, quando alimentada, ainda mais os instiga a fazer dano.

\section{Os Caminhantes e O URSo (HsR. 66, СН. 254)}

Dois amigos caminhavam pelo mesmo carreiro. Então, como lhes aparecesse um urso, um deles subiu

${ }^{25}$ Célebre político ateniense, pró-macedónico, (350-315 a.C.), que terá tentado levar a cabo um processo de deificação de Alexandre da Macedónia. 
precipitadamente a uma árvore e escondeu-se ali; o outro, a ponto de ser apanhado, deixou-se cair no chão e fingia-se de morto. Ora, como o urso aproximasse o focinho e o farejasse, sustinha a respiração - pois diz-se que este animal não toca num cadáver. Quando ele se foi embora, o que estava na árvore perguntou-lhe o que lhe dissera o urso. Então, aquele respondeu: "Para de futuro não viajar com semelhantes amigos."

A fábula mostra que as desgraças testam os verdadeiros amigos.

\section{Os Rapazes E O CARNICEIRo (HsR. 67, CH. 246)}

Dois rapazes compravam carne no mesmo sítio. E, enquanto o carniceiro estava distraído, um ia subtraindo os despojos e largava-os no manto do outro. Então, o carniceiro pôs-se à procura dos despojos e acusava-os. Ora, por um lado o que os tomara jurava não os ter, e o que os tinha, não os ter tomado. Mas o carniceiro, percebendo a marosca, disse: "Na verdade, ainda que me enganeis com falsos juramentos, aos deuses não os ocultareis."

A fábula mostra que a impiedade do perjúrio é a mesma, ainda que se dissimule com sofismos.

\section{Os Caminhantes E O Machado (HsR. 68, CH. 256)}

Dois homens viajavam juntos. Ora, tendo um deles encontrado um machado, o outro disse: "Encontrámos! O primeiro corrigia-o para não dizer: "Encontrámos", mas "Encontraste". Pouco tempo depois, ao virem até eles os que tinham perdido o machado, aquele que o tinha, perseguido, disse para o companheiro de viajem: "Estamos perdidos" e o outro replicou: "Não (estamos perdidos), antes, 'estou 
perdido', pois quando encontraste o machado, não me deste sociedade dele."

A fábula mostra que os que não obtêm parte das situaçóes afortunadas, tampouco são amigos seguros nas desgraças.

\section{Os inimigos (Hsr. 69, Сн. 114)}

Dois inimigos navegavam no mesmo barco mas, como queriam estar longe um do outro, mudaram-se um para a proa e o outro para a popa e aí ficaram. Porém, caiu uma violenta tempestade e o barco virou-se. Então, o que estava na popa perguntou ao timoneiro de que parte havia o risco do barco se afundar primeiro. E como aquele respondesse "da proa", disse: "Pois já não é penosa para mim a morte, se vejo o meu inimigo morrer antes de mim."

Da mesma forma, alguns homens, por hostilidade ao próximo, não se importam de sofrer algo terrível, desde que vejam antes a desgraça dos outros.

\section{As RÃS VIZINHAS (HsR. 70, СH. 67)}

Duas râs viviam próximas uma da outra. Uma vivia num charco profundo, distante do caminho, e a outra numa poça pequena, na estrada. Então, a que estava no charco aconselhou a outra a mudar-se para junto dela, onde teria uma vida melhor e mais segura. Aquela, náo era persuadida e dizia ter dificuldade em sair do seu lugar habitual. Até que aconteceu que um carro que passava por ali a matou.

Dessa forma, também os homens que passam a vida em ocupaçóes vis morrem antes de se virarem para outras melhores. 


\section{A aZinheira E a cana (Hsr. 71, СH. 101)}

Uma azinheira e uma cana discutiam a propósito da sua resistência. Ora, ao gerar-se um forte vento, a cana, como se curvava e inclinava ante o sopro dele, safou-se de ser arrancada; enquanto a azinheira, por resistir, foi arrancada pela raiz. ${ }^{26}$

A fábula mostra que nem devemos rivalizar, nem resistir aos que são mais fortes.

\section{O HOMEM COBARDE QUE ENCONTROU UM LEÁO DE OURO (Hsr. 72, Сн. 62)}

Um covarde avarento, ao encontrar um leão de ouro, disse para consigo: "Não sei que atitude tomar na presente situação. Eu sinto-me despojado de ideias e náo sei o que deva fazer. Estou divido entre o amor pela riqueza e a cobardia natural. Mas que sorte ou que divindade teráo modelado um leão de ouro? E é por isso que a minha alma, nesta circunstância, se debate com ela própria: por um lado, sente afeiçấo pelo ouro, por outro teme realmente o artefacto de ouro. O desejo induz a deitar-lhe mão, mas o temperamento retrai-se. Ó fortuna, que ofereces mas não concedes colher. Ó tesouro que não traz prazer. Ó graça de divindade que se torna ingrata! E agora? Por que forma a vou possuir? Com que estratagema lhe chego? Vou partir e trazer para aqui os

${ }^{26}$ Cf. Com o símile no discurso de Hémon na Antígona de Sófocles (vv. 712-714): "Bem vês que, nas torrentes invernais, quando as árvores cedem, os ramos se salvam; quem oferece resistência, perde-se com as próprias raízes." Trad. Maria Helena da Rocha Pereira (Rocha Pereira 2004) 
criados que o devem levar, por meio da multidão de aliados; e eu, à distância, serei espectador". ${ }^{27}$

A fábula adequa-se a qualquer rico que não tenha coragem para tocar e servir-se da riqueza.

\section{O Apicultor (HsR. 75, Сh. 235)}

Um certo homem que encontrou a casa de um apicultor, quando aquele se ausentou, levou o mel e os favos. Ao regressar, e tendo visto as colmeias vazias, (o apicultor) pôs-se a examiná-las. Entretanto, também as abelhas voltaram da colheita e, ao surpreendê-lo, atacaram-no com os aguilhōes e maltrataram-no de forma terrível. Então, o apicultor disse: "Ó bichos malvados, vós deixastes ir impune o que roubou os favos e a mim, que cuido de vós, picais-me!"

Da mesma forma, alguns homens, por ignorância, não se guardam dos inimigos e atacam os amigos como se fossem traidores.

\section{O golfinho E O Macaco (HsR. 75, СН. 305)}

Havia entre os marinheiros o hábito de trazer cachorros e macacos de Malta para servirem de distracção durante a viagem. Pois, aconteceu que um que se fez ao mar trouxe consigo um macaco. Entretanto, chegados ao Súnio - que é um promontório da Ática ${ }^{28}$ - sucedeu formar-se uma forte

${ }^{27}$ Cf. esta fábula com o texto egípcio "O debate entre o homem e a sua alma” (Papyrus Berlin 3024, vide Allen 2011).

${ }^{28}$ Este passo pode sugerir que o receptor desta fábula não fosse oriundo da Grécia continental ou, pelo menos, da região da ática. Isto porque este promontório seria muito conhecido no espaço marítimo helénico, dado que aí se encontrava um templo consagrado a Posídon - o primeiro que os navegantes veriam ao chegar à costa da ática -, pelo que seria prescindível a explicação sobre o Súnio. 
tempestade. O barco virou, mas todos conseguiram salvar-se a nado e também o macaco nadava.

Com efeito, um golfinho que o viu, julgando ser um homem, deslizou para debaixo dele e carregou-o. Quando chegou ao Pireu, o porto de Atenas, perguntou ao macaco se era ateniense de nascimento. E o macaco disse que sim e que por acaso até tinha ali pais ilustres. Então, o golfinho perguntou-lhe se conhecia o Pireu e o macaco, pensando que estaria a falar de um homem, respondeu que sim e, em boa verdade, até era um dos seus amigos íntimos. O golfinho, irritado com aquela mentira, mergulhou e afogou-o.

Para os homens farsantes a fábula é oportuna.

\section{O VEADO NA FONTE (HsR. 76, CH.102)}

Um veado, atormentado pela sede, chegou a uma fonte. Depois de beber, como visse o seu próprio reflexo na água, orgulhou-se dos seus chifres, ao reparar no seu tamanho e variedade; todavia, envergonhava-se das suas patas por serem finas e fracas. Enquanto matutava nisto, apareceu um leão que o perseguiu e ele, precipitando-se em fuga, deu-lhe um grande avanço. $\mathrm{Na}$ verdade, como a planície estava pelada, o veado estava a salvo, pois levava vantagem.

Porém, quando chegou a um lugar florestado, nesse momento, aconteceu os chifres enredarem-se nuns galhos e, como não conseguia correr, foi apanhado. Então, estando a ponto de morrer, disse para si próprio: "Mísero de mim, que me salvo por causa daquilo que julgava que me trairia e por causa daquilo em que mais me fiava é que pereço.”

Da mesma forma, muitas vezes nos perigos os amigos suspeitos fazem-se protectores e aqueles em quem mais confiávamos traidores. 


\section{O veado mutilado (Hsr. 77, Сн. 105)}

Um veado, que magoara um dos olhos, chegou à costa e deixou-se aí ficar; punha o olho bom na terra para atentar em caçadores e o olho magoado no mar, pois dali não suspeitava de nenhum perigo. Foi entáo que uns que navegavam por ali, ao vê-lo, atiraram um dardo e, consequentemente, estando a ponto de morrer, (o veado) disse para si: "Ah, miserável de mim, que vigiava a terra como traiçoeira, enquanto o mar, onde me refugiei, resultou muito pior."

Da mesma forma, muitas vezes, contrariamente àquilo que julgamos, os assuntos que pareciam adversos mostram-se úteis, ao passo que o considerado seguro é perigoso.

\section{O veado e O leấo numa gruta (Hsr. 78, CH. 104)}

Um veado que fugia de caçadores chegou a uma grutaonde estava um leão - e entrou ali para se esconder. Contudo, foi capturado por um leão e, ao morrer, disse: "Infortunado de mim, que ao fugir dos homens, caí eu mesmo nas mãos de uma fera."

Da mesma forma, alguns homens, por medo de perigos menores, sofrem males maiores.

\section{O veado e a parra (Hsr. 79, Сh. 103)}

Um veado, perseguido por uns caçadores, escondeu-se sob uma parra. E depois dos caçadores passarem por ali, pôs-se a comer-lhe as folhas. Ora, um dos caçadores, ao voltar-se, viu-o e feriu-o, ao lançar o dardo que tinha. Então o veado, quando estava a ponto de morrer, disse para si entre gemidos: "Sofro o justo, porque prejudiquei a parra que me protegia." 
Assim, a fábula podia aplicar-se aos homens que, por prejudicarem aqueles que os favorecem, são castigados pelos deuses.

\section{Os Marinheiros (HsR. 80, С . 308)}

Uns homens, tendo subido para um barco, navegavam. Mas quando estavam em alto mar, desabou uma violenta tempestade e pouco faltou para o barco se afundar. E um dos marinheiros, ao rasgar as roupas, evocava os deuses pátrios, entre prantos e lamentos, prometendo que lhes ofereceria sacrifícios de agradecimentos, caso se salvassem. Porém, quando a tempestade passou e acalmia voltou, foram tomados pela alegria e puseram-se a dançar e a saltar, como tivessem escapado de um perigo inesperado.

Ora o piloto, que era um homem razoável, disse-lhes: "Na verdade, ó amigos, devemos regozijar-nos como se a tempestade pudesse voltar de novo."

A fábula ensina a não exaltar-se demasiado com as circunstâncias felizes, lembrando a mutabilidade da fortuna.

\section{A doninha e os Ratos (Hsr. 81, CH. 13)}

Numa certa casa havia muitos ratos. Uma doninha, quando o soube, entrou ali e, caçando-os um a um, comia-os. Então os ratos, consumidos constantemente, enfiaram-se nas suas tocas e a doninha, como não era capaz de os alcançar, compreendeu ser necessária um estratagema para os provocar. Por isso, subiu a uma estaca e, deixando-se estar ali, fingia-se de morta. Um dos ratos disse ao vê-la: "Ah, ainda que tu 
fosses um $\operatorname{saco}^{29}$, não me aproximaria de ti."

A fábula mostra que os homens prudentes, quando têm a experiência das maldades de alguns, não se deixam enganar pelas suas trapaças.

\section{As moscas (HsR. 82, СH. 239)}

Numa despensa fora derramado mel e as moscas, que para ali voavam, alimentavam-se dele e por causa da doçura do alimento não se iam. Porém, as patas ficaram presas e não podiam voar dali, pelo que, ao asfixiar, disseram: "Desgraçadas de nós, que perecemos por um curto prazer."

Dessa forma, para muitos a gula é a causa dos males.

\section{O MACACO, QUE FOI ELEITO REI, E A RAPOSA (HsR. 83, Сн. 38)}

Numa assembleia de animais irracionais ${ }^{30}$, um macaco, que gozava de simpatia (dos demais), foi eleito rei pelos outros. E uma raposa, invejosa dele, ao ver um pedaço de carne colocado numa armadilha, conduziu o macaco até lá dizendo que tinha encontrado um tesouro; ela, todavia, não o usou, porque percebeu que era prémio de realeza para ele, e instigou-o a tomá-lo para si.

Ora o macaco, ao aproximar-se descuidadamente, caiu e acusou a raposa de o ter enganado. Esta respondeu: "Então tu, macaco, com semelhante inteligência, ainda pretendes governar sobre os animais irracionais?"

${ }^{29}$ Em causa estaria um saco de pele, que provavelmente sugeria a existência de víveres no seu interior.

${ }^{30}$ Considerámos pertinente a tradução literal do termo $\alpha \lambda$ ó $\gamma \omega v$, pois a fábula esópica insiste em distinguir o animal do homem através desta terminologia. 
Do mesmo modo, os que irreflectidamente se lançam nas empresas caiem no infortúnio e tornam-se alvos de chacota.

\section{O burro, o galo e o leáo (Hsr. 84, Сh. 269)}

Num estábulo estavam um burro e um cavalo. E um leão esfomeado, quando viu o burro, estava a ponto de entrar para os devorar. Mas, com o barulho do galo que se pôs a cacarejar, assustou-se - diz-se, de facto, que os leóes se assustam com os sons do galo - e pôs-se em fuga.

E o burro, excitado consigo mesmo, embora o leão fugisse com medo do galo, saiu em perseguição dele. Ora, quando se encontrava já a grande distância (dali), o leão comeu-o.

Da mesma forma, também alguns homens, ao verem os seus inimigos submissos, logo se encorajam com isso e, sem perceberem, são por eles destruídos.

\section{O MACACO E O CAMELO QUE DANÇAVAM (Hsr. 85, СH. 306)}

Numa reunião de animais irracionais, um macaco levantou-se e pôs-se a dançar. E, por ser bastante apreciado e aplaudido por todos, um camelo, invejoso, quis ter o mesmo sucesso. Por isso, levantou-se e tentou também dançar. Mas como fez muitas coisas estranhas, os animais, irritados, expulsaram-no batendo-lhe com paus.

Para os que, por causa da inveja, competem com os mais fortes e, em seguida fracassam, é a fábula oportuna. 


\section{Os dois escaravelhos (HsR. 86, CH. 149)}

Numa certa ilhota havia um touro que pastava; e no seu esterco alimentavam-se dois escaravelhos. Então, ao chegar o inverno, disse um ao outro amigo que gostaria de voar para terra firme, para que aquele que ficasse só tivesse comida suficiente; enquanto ele, partindo, passaria o inverno noutro lugar. Disse ainda que, se encontrasse muito alimento, também o traria para ele. Uma vez porém em terra firme, ao encontrar esterco abundante e fresco, ficou ali e alimentou-se. Terminado o inverno, voou de regresso à ilha $\mathrm{e}$ o outro, ao vê-lo gordo e saudável, censurou-o por causa da promessa feita, já que nada lhe trouxe. E o outro respondeu: "Não me culpes a mim, antes à natureza do lugar. Pois ali é possível alimentar-se, mas não trazer nada."

Esta fábula podia aplicar-se aos que dão amizade apenas até estarem fornecidos, mas que, demais disso, em nada auxiliam os amigos.

\section{O porco e as ovelhas (Hsr. 87, Сh. 94)}

No meio de um rebanho de ovelhas um porco, que aí chegara, pastava. E certo dia, agarrado pelo pastor, grunhia e resistia. Então, as ovelhas reprovavam-no pelos gritos, dizendo: "Pois a nós não leva ele de vez em quando e sem balirmos?"

A isso o porco respondeu: "Mas a vós não colhe pelo mesmo que a mim. Pois a vós leva-vos por causa da lã ou do leite, a mim, porém, por causa da carne."

A fábula mostra que gritam com razão as que têm em perigo não os seus pertences, mas a sua salvação. 


\section{O TORdo No ARbUSto de MiRTilos (HsR. 88, CH. 157)}

Um tordo ocupava-se num arbusto de mirtilos e não o deixava por causa da doçura dos frutos. Ora, um passarinheiro, ao perceber que estava a jeito, apanhou-o com uma rede. E quando o tordo estava a ponto de morrer, disse: "Pobre de mim, que por causa da doçura do alimento, sou privado da salvação."

Para o homem corrompido, que se perde pelo prazer, a fábula é oportuna.

\section{A galinha dos ovos de OURo (Hsr. 89, CH. 288D)}

Hermes, venerado de forma extraordinária por um homem, recompensou-o com uma galinha que punha ovos de ouro. Ora, como aquele, impaciente por ser um lucro faseado, acreditasse que o interior da galinha era inteiramente de ouro, não esperou e sacrificou-a. Mas aconteceu que não só se enganou no que pensava, como também perdeu os ovos, pois por dentro era toda carne.

Da mesma forma, muitas vezes os gananciosos, por causa do desejo de maiores lucros, perdem também o que têm entre mãos.

\section{Hermes e o escultor (Hsr. 90, Ch. 108)}

Hermes, querendo saber em que estima o tinham os homens, tomou o aspecto humano e foi à oficina de um escultor. Então, ao ver a estátua de Zeus, perguntou: "Quanto?" e o escultor respondeu: "Um dracma." E rindo perguntou: "Qual é o preço da de Hera?" Ao que o outro respondeu ser um pouco mais cara. E, como visse a própria estátua, pensou que, como era o mensageiro (dos deuses) e protector do comércio, os homens o teriam em grande 
consideração, pelo que por isso perguntou: "E quanto custa o Hermes?" e o escultor disse: "Mas se comprares essas, esta eu dou-ta de oferta."

A fábula ajusta-se ao homem vaidoso, que não goza da estima dos demais.

\section{Hermes e Tirésias (Hsr. 91, Ch. 110)}

Hermes queria provar se a capacidade divinatória de Tirésias era verdadeira e, tendo-lhe roubado os bois do campo, tomou a forma humana, foi vê-lo à cidade e hospedou-se na casa dele. Quando contaram a Tirésias a perda da sua junta, foi com Hermes aos arrabaldes para indagar sobre um augúrio acerca do roubo e pedia que lhe dissesse se vira alguma ave. Ora, Hermes viu primeiro uma águia a voar da esquerda para a direita e assim o expôs. E Tirésias disse que esse não dava. Em segundo lugar, viu uma gralha pousada numa árvore e que ora olhava para o céu, ora se inclinava para terra - e dessa forma o fez saber. Então, em resposta disse: "Pois essa gralha jura pelo céu e pela terra que se tu quiseres, irei recuperar os meus bois.

Alguém poderia servir-se desta fábula contra o homem burlão.

\section{A víbora E A Hidra (COBRa de ÁGUA) (HsR. 92, CH. 117) ${ }^{31}$}

Uma víbora saiu para ir beber a uma fonte. Mas a hidra, que ali vivia, impedia-a, desagradada, por não lhe bastar a sua própria comida, mas ainda vir até ao habitat dela.

${ }^{31}$ Usualmente entende-se que esta fábula constituída por dois agones é também uma metáfora ao filósofos cínicos, aqui representados pelas rãs. Cf. Adrados 2003, vol.3, p. 121. 
E, como a rivalidade aumentasse sempre, decidiram, por isso, enfrentar-se em peleia uma com a outra e que do vencedor fossem os alimentos da terra e da água. Fixado o dia para a contenda, as rãs, por ódio à hidra, aproximaram-se da víbora e encorajaram-na, prometendo fazer-se suas aliadas.

Tendo-se iniciado o combate, a víbora lutava com a hidra e as rãs, como não eram capazes de fazer nada mais, coaxavam alto. Quando a víbora venceu, acusava-as de que tinham prometido ser suas aliadas, mas durante o combate, não só não tinham ajudado, mas ainda cantavam. Então, as râs disseram-lhe: "Mas vê bem que a nossa ajuda não se processa através das mãos, mas apenas através do som."

A fábula mostra que quando é necessário ajuda com as mãos, a ajuda pelas palavras nada vale.

\section{O burro Que brincava e O amo (Hsr. 93, Сh. 275)}

Certo homem, que tinha um cão maltês e um burro, passava o tempo constantemente a brincar com o cão. E, se em algum momento saía para comer, trazia alguma coisa que lhe lançava, quando aquele se aproximava e abanava o rabo. Entáo, o burro, cheio de ciúme, correu para o dono e, pondose a fazer cabrioladas, deu um coice ao amo. E este, irritado, ordenou que conduzissem o burro a golpes e o atassem à manjedoura.

A fábula mostra que nem todos nasceram para o mesmo.

\section{Os doIs Cáes (HsR. 94, СH. 175)}

Certo dono de dois cães ensinou um a caçar e o outro a guardar a casa. Entáo, se acaso o caçador saía para caçar e trazia uma peça, o dono atirava uma porção ao guarda. E 
como se o caçador se irritasse e reprovasse o guarda - uma vez que ele próprio se esfalfava a todo o momento, enquanto o outro sem fazer nada disfrutava do seu próprio esforço o guarda disse-lhe: "Mas não me censures a mim, antes ao amo, que me ensinou a não trabalhar e a comer do trabalho de terceiros.

Da mesma forma, não são as crianças frívolas repreensíveis, uma vez que os pais os educaram desse modo.

\section{A víbora e a lima (HsR. 95, CH. 116)}

Uma víbora entrou na oficina de um ferreiro e pedia tributo às ferramentas. $\mathrm{E}$ ao receber delas (o pagamento), chegou junto da lima, e exortava-a a dar-lhe alguma coisa. Mas ela, em resposta, replicou-lhe: "Mas que tonta és, se pensas vir a obter algo de mim, eu que não costumo dar, antes tomo de todos."

A fábula mostra que são tolos os que esperam receber alguma coisa dos avarentos.

\section{O pai e as filhas (Hsr. 96, СH. 299)}

Um certo homem que tinha duas filhas deu uma em casamento a um hortelão e outra a um oleiro. Algum tempo mais tarde foi visitar a do hortelão e perguntou-lhe como passava e como iam as coisas. Ora, ela respondeu-lhe que tudo estava bem, porém pedia apenas que se fizesse inverno e chuva para que regasse as hortaliças. Pouco depois foi visitar a do oleiro e perguntou-lhe como estava. Ela respondeu que nada lhe faltava, mas que pedia apenas que durasse o céu limpo e o sol brilhante para que a cerâmica secasse. Então, o pai disse-lhe: "Se tu desejas bom tempo e a tua irmã inverno, a qual de vós me uno nas preces?" 
Da mesma forma, os que se ocupam ao mesmo tempo de diferentes assuntos, naturalmente fracassam em ambos.

\section{O Marido e a mUlher problemática (Hsr. 97, CH. 49)}

Um certo homem, que tinha uma mulher que era desagradável para com toda a gente, quis saber se ela também teria o mesmo comportamento para com os escravos domésticos do pai, pelo que a mandou para junto do pai, usando de um pretexto verosímil. Regressada, ao fim de poucos dias, (o marido) perguntou-lhe como a tinham recebido os criados. Ao que ela disse: "Os boieiros e os pastores olhavam-me de esguelha”. Ele disse-lhe: “Mas, ó mulher, se provocaste ódio nestes que saem ao amanhecer com os rebanhos e que regressam pela tarde, o que esperar daqueles com quem convives todo o dia?"

Da mesma forma, muitas vezes se percebe o importante através das pequenas coisas e o ignoto através das coisas evidentes.

\section{A víbora e a Raposa (Hsr. 98, Ch.115)}

Uma víbora era arrastada com um arbusto de espinhos para um rio. Então, uma raposa que lá estava, quando a viu, disse: "É digno da embarcação o comandante."

Contra o homem malvado que pratica actos perversos.

\section{O CORDEIRo E O LObO FlaUtista (HsR. 99, CH. 107)}

Um cordeiro, desgarrado do rebanho, era perseguido por um lobo. Então, o cordeiro virou-se para o lobo e disse: "Estou convencido, ó lobo, de que sou tua refeição. Mas para não morrer sem glória, toca a flauta, para eu dançar." Ora, quando, porém, o lobo se pôs a tocar e o cordeiro a dançar, os 
cães, ouvindo-os, perseguiram o lobo. E este, virando-se diz para o cordeiro: "Fizeste-ma bonita, pois eu, sendo magarefe, não devia imitar um flautista.

Da mesma forma os que agem contra a sentença da ocasião também são privados do que têm em mãos.

\section{O CABRito QUE ESTAVA EM CASA E O LOBO}

(Hsr. 100, СH. 106)

Um cabrito, que estava em casa, censurava um lobo que passava próximo. Então o lobo disse-lhe: "Não és tu que zombas de mim, mas o lugar."

A fábula mostra que as ocasióes dão coragem contra os mais fortes.

\section{O vendedor de estátuas (HsR. 101, С . 2)}

Um certo homem, que talhara um Hermes de madeira, levou-o para a ágora a fim de o vender. Porém, como nenhum comprador se aproximasse e ele quisesse atrair alguns, apregoava vender um deus benfazejo e causador de lucros. Então, um que por ali estava disse-lhe: "Eh tu, mas porque o vendes, se é como dizes, em vez de aproveitares os benefícios que traz? E aquele respondeu: "É que eu preciso de benefício imediato e este tem por costume favorecer tardiamente."

Para o homem avaro, que não se preocupa com os deuses, esta fábula é oportuna. 


\section{Zeus, Prometeu, Atena e Momo ${ }^{32}$}

\section{(Hsr. 102, CH. 124)}

Zeus, Prometeu e Atena - que haviam criado, o primeiro um touro, Prometeu um homem e a deusa uma casa - elegeram Momo como juiz. Este, invejoso das criaçóes deles, começou por dizer que Zeus se tinha enganado por não colocar os olhos do touro nos cornos para que visse onde marrava. Prometeu, porque não tinha posto o entendimento no exterior do homem, para que dessa forma não passassem inadvertidos os malvados e fosse bem visível o que cada um tinha no pensamento. Em terceiro lugar, disse que Atena devia ter posto rodas na casa, de modo a que se algum vizinho malvado vivesse ao lado, pudesse mudar-se facilmente. $\mathrm{E}$ Zeus, indignado com ele pela sua inveja, lançou-o para fora do Olimpo.

A fábula mostra que não há nada tão perfeito, que não admita nenhuma censura.

\section{A gralha e os pássaros (Hsr. 103, Сн. 162)}

Zeus, querendo designar um rei entre os pássaros, impôs-lhes um dia para se apresentarem diante de si. Então a gralha, consciente da sua própria fealdade, ao passar entre os pássaros, ia apanhando as penas caídas e punha-as em si própria. Ora, quando chegou o dia, transformada numa ave vistosa, apresentou-se perante Zeus. Mas quando estava a ponto de ser designada líder, por causa da aparência, os pássaros, irados, rodearam-na e cada um tirou a sua pena. Assim sucedeu que ela, depenada, voltou a ser gralha.

\footnotetext{
${ }^{32}$ Personificação do sarcasmo.
} 
Da mesma forma, também os homens endividados, ainda que ao possuírem o dinheiro alheio pareçam ser alguém, quando o devolvem encontram-se como estavam no princípio.

\section{Hermes e Gaia (Hsr. 104, Ch. 109)}

Quando Zeus moldou o homem e a mulher, ordenou a Hermes que os levasse até Gaia ${ }^{33}$ e lhes mostrasse onde deviam cavar a fim de obterem sustento. Tendo Hermes cumprido a ordem, Gaia, a princípio, protestava. No entanto, como Hermes insistisse, dizendo que era uma ordem de Zeus, Gaia disse: "Muito bem, que cavem à vontade, mas hão-de retribuir-me com suspiros e lágrimas."

Para aqueles que com muita facilidade pedem emprestado, mas que pagam com sofrimento, a fábula é oportuna.

\section{Hermes e os artesáos (Hsr. 105, Сh. 111)}

Zeus ordenou a Hermes que vertesse sobre todos os artesãos a poção do engano. Então, aquele preparou-a e derramou-a sobre cada um em partes iguais. Contudo, como apenas faltava o sapateiro e ainda sobrava muita poção, reuniu todo o composto e despejou-o sobre ele. Pois aconteceu que, desde esse momento, todos os artesãos são mentirosos, porém, mais dos que todos, são os sapateiros.

Para os homens mentirosos, a fábula é oportuna.

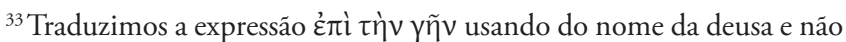
a ideia espacial de terra. Ainda que seja esse o sentido literal, optámos por manter a relação mitológica implícita no texto e, nesse sentido, manifestar a simbiose entre o conceito material 'terra' e a divindade. 


\section{Zeus e Apolo (Hsr. 106, Сh. 121)}

Zeus e Apolo competiam no uso do arco. Ora, Apolo retesou o arco e disparou o dardo; enquanto isso, Zeus deu uma passada táo grande quanto o alcance do tiro de Apolo.

Da mesma forma, os que rivalizam com os mais fortes, além de não ficarem à sua altura, também se expõem ao ridículo.

\section{Os ANOS DO HOMEM (HsR. 107, СH. 139)}

Quando Zeus criou o homem, atribuiu-lhe uma vida efémera. Contudo este, servindo-se da sua inteligência, com a chegada do inverno construiu uma casa para si e ali vivia. Pois então, numa altura em que fazia muito frio e Zeus enviara chuva, o cavalo, que não conseguia resistir-lhe, galopou até ao homem e pediu-lhe que também o abrigasse. Este disse que não o faria, a menos que lhe desse uma parte dos seus próprios anos (de vida). E o cavalo aceitou de bom grado. Não muito tempo depois, apareceu um boi, que também não era capaz de resistir ao inverno. Da mesma maneira, o homem disse que não o acolheria, a não ser que lhe desse um certo número dos seus anos; e ele deu-lhe uma porção e foi acolhido. Por fim, chegou um cão, que estava a morrer de frio e que conseguiu abrigo, ao conceder parte da sua idade. Assim, sucedeu que os homens, até que cheguem ao tempo que Zeus lhes deu, são puros e bons; quando atingem a idade do cavalo são fanfarróes e prepotentes; chegados à idade do boi, fazem-se dominantes; e quando atingem a idade do cáo, tornam-se irascíveis e resmungóes.

Esta fábula poderia aplicar-se ao velho colérico e intratável. 


\section{Zeus e a tartaruga (Hsr. 108, С . 125)}

Ao celebrar as núpcias, Zeus decidiu convidar todos os animais para um banquete, ao qual apenas faltou a tartaruga. Ignorando a causa, no dia seguinte perguntoulhe porque razão só ela não havia comparecido ao banquete. Esta respondeu-lhe: "A nossa própria casa é a melhor das casas."

Então Zeus, furioso com ela, condenou-a a carregar a própria casa por todo o lado.

Da mesma forma, muitos homens preferem viver em casa de forma modesta, a viver faustosamente em casa alheia.

\section{Zeus e a Raposa (Hsr. 109, Сh. 119)}

Zeus, admirado com a inteligência e destreza do espírito da raposa, fê-la rainha dos animais irracionais. E, querendo saber se, ao mudar a sorte dela, transformaria também a sua condição, quando a transportavam numa liteira, Zeus colocou um escaravelho à sua vista. Então ela, incapaz de se conter, porque aquele voava à volta da liteira, saltou desastradamente e tentava apanhá-lo. Então Zeus, indignado com ela, devolveu-lhe o antigo posto.

A fábula mostra que os homens vis, mesmo que tomem ornamentos mais ilustres, não mudam por certo a sua natureza.

\section{Zeus e os homens (Hsr. 110, Сн. 120)}

Quando Zeus moldou os homens, mandou Hermes incutir-lhes inteligência. Este, depois de dividir em partes iguais, verteu-a sobre cada um. Mas aconteceu que os homens de baixa estatura, impregnados em toda a proporção, 
fizeram-se sensatos. Contudo, os altos, como a beberagem não chegou a todo o corpo [nem sequer aos joelhos], fizeram-se menos prudentes do que os outros.

Para o homem de corpo grande, mas com espírito insensato, a fábula é oportuna.

\section{Zeus e o Pudor (Hsr. 111, Ch. 118)}

Quando Zeus moldou os homens e infundiu neles diferentes sentimentos, somente esqueceu o Pudor. E ele, não sabendo onde introduzi-lo, ordenou-lhe que entrasse pelo ânus. Ao início, o Pudor, indignado, recusou-se. Porém, depois de Zeus insistir veementemente com ele, disse: "Mas se entrar outro atrás de mim, saio de imediato." Daqui percebe-se serem desavergonhados todos os sodomitas.

Esta fábula poderia aplicar-se ao homem lascivo.

\section{O HERó (HsR. 112, СH. 131)}

Certo homem, que tinha um herói ${ }^{34}$ em casa, fazia-lhe opulentos sacrifícios. E como sem cessar gastasse e consumisse muitos (recursos) em oferendas, o herói apareceu-lhe à noite e disse: "Apre, ó homem, pára de delapidar os teus bens. Pois se gastares tudo e ficares pobre, vais culpar-me."

Da mesma forma, muitos que pela sua própria estupidez são miseráveis, atiram a culpa aos deuses.

\footnotetext{
${ }^{34}$ Estatueta de culto de um herói (ท̆ $\left.\rho \omega \varsigma\right)$.
} 


\section{Héracles e Pluto $^{35}$ (Hsr. 113, Ch. 130)}

Héracles, tendo sido deificado e convidado para um banquete na morada de Zeus, saudava os deuses um por um, com muita amabilidade. Porém, tendo chegado Pluto em último lugar, Héracles baixou os olhos para o chão e afastou-se. Ora, Zeus, admirado pelo sucedido, perguntou-lhe porque motivo, tendo saudado de forma cortês todos os deuses, tinha desconsiderado Pluto. Entâo, Héracles disse: "Pois bem, eu desvio os olhos dele por isto: durante o período em que eu estava entre os homens, via-o frequentemente com os malvados."

A fábula poderia ser contada a propósito do homem rico por causa da sorte, mas de carácter perverso.

\section{A formiga e o escaravelho (Hsr. 114, Сh. 241)}

Durante o verão, uma formiga deambulava pelo campo e colhia grãos de trigo e cevada, armazenando alimento para o inverno. Um escaravelho, ao vê-la, ficou muito admirado por ela ser tão laboriosa, uma vez que labutava tão arduamente, ao mesmo tempo que os outros animais, libertos de trabalhos, se entregavam ao descanso. Nessa altura, a formiga permaneceu em silêncio, mas mais tarde, quando o inverno chegou e os excrementos ficaram desfeitos pela chuva, o escaravelho foi ter com a formiga, esfomeado e necessitado de obter comida. Então ela disse-lhe: "Ó escaravelho, se tivesses trabalhado quando eu me esforçava e tu me criticavas, agora não terias falta de comida."

Do mesmo modo, os que durante a abundância não pensam no futuro, sofrem as maiores misérias com a mudança dos tempos.

${ }^{35}$ Divindade que personifica a riqueza e a abundância. 


\section{O Atum E O Golfinho (Hsr. 115, СH. 132)}

Um atum, perseguido por um golfinho, fugia impetuosamente e, quando estava a ponto de ser capturado, sem dar-se conta, foi parar ao areal de uma praia por causa do forte impulso (que levava). E, empurrado também pelo seu movimento, o golfinho foi projectado para o mesmo sítio. Entâo o atum, ao vê-lo moribundo, virou-se para ele: "A morte já não é penosa para mim, pois vejo que padece comigo o culpado pelo meu perecimento."

A fábula mostra que os homens suportam facilmente as desgraças, quando vêem que também padecem os seus causadores.

\section{O MÉdico no fUNeral (HsR. 116, СH. 134)}

Um médico, que acompanhava os parentes de um homem que ia a enterrar, disse aos que estavam na frente do cortejo que, se aquele homem se tivesse abstido de vinho e tivesse aplicado clisteres, não estaria morto. Então, um dos presentes disse: "Eh tu, não é agora que devias dizer isso, quando náo vale de nada, mas sim aconselhá-lo quando ele ainda podia aproveitar os teus conselhos."

A fábula mostra que deve ajudar-se os amigos nos momentos de necessidade e não ironizar depois das coisas sucedidas.

\section{O passarinheiro e a ÁSPIDe (Hsr. 117, СH. 137)}

Um passarinheiro, munido de linha e canas, saiu para pescar. Mas, ao ver um tordo pousado no cimo de uma árvore, teve desejo de o apanhar. Depois de juntar as canas em extensão, observava atento, com todo o pensamento 
posto no ar. Desse modo, de cabeça virada para cima, sem dar conta, pisou uma áspide que dormia diante dos seus pés que, voltando-se, o mordeu. E ele, ao sentir a vida a abandoná-lo, disse para si próprio: "Miserável de mim, que, por querer caçar o outro, sem dar conta, eu próprio fui presa para a morte."

Dessa forma, os que montam armadilhas para os seus próximos acabam eles mesmos por cair em desgraça.

\section{O caranguejo e a raposa (Hsr. 118, Ch. 150)}

Um caranguejo saiu do mar e vivia sozinho numa praia. Então, uma raposa que procurava comida, quando o viu, correu para ele e apanhou-o. Mas ele, vendo-se em risco de ser devorado, disse: "Pois eu sofri o que era justo, porque, sendo marinho, quis fazer-me terrestre."

Da mesma forma, os homens que abandonam a sua casa e hábitos e, se ocupam do que não lhes diz respeito, naturalmente fazem a (a própria) desgraça.

\section{O CAMElo QUE QUERIA TER CORNos (HsR. 119, CH. 146)}

Um camelo, ao ver um touro que se orgulhava dos seus cornos, invejou-o e teve vontade ter uns iguais. Portanto, apesentou-se perante Zeus, requerendo que lhe fossem atribuídos cornos. Todavia, Zeus, indignado com ele - pois não lhe eram suficientes o tamanho do seu corpo e a sua força, mas ainda desejava algo mais - não só não lhe deu os cornos, como ainda lhe tirou parte das orelhas.

Da mesma forma, muitos por ambição, ao olhar com inveja para os outros, sem darem por isso, também ficam sem o que é seu. 


\section{O CASTOR (Hsr. 120, Ch. 153)}

O castor é um animal quadrúpede que habita os lagos. Acerca dele conta-se que os seus genitais são úteis para certas terapias. Portanto, se ao vê-lo alguém o persegue, como sabe por qual abono o faz, (aquele) foge até uma certa distância, valendo-se da velocidade das suas patas, de modo a preservar-se inteiro. Mas quando fica cercado, corta os genitais, atira-os e assim consegue a salvação.

Da mesma forma, são sensatos os homens que, quando estão em sarilhos por causa da riqueza, a sacrificam para não colocar em perigo a própria vida.

\section{O horteláo que regava hortaliças (Hsr. 121. Ch.}

\section{4)}

Certa pessoa, detendo-se junto de um horteláo que regava as hortaliças, perguntou-lhe porque motivo as silvestres eram viçosas e robustas, ao passo que as cultivadas estavam débeis e secas. Então o hortelão disse: "A terra é mãe para umas e madrasta para outras."

Assim, as crianças criadas por uma madrasta não o são de maneira igual às que têm mães.

\section{O horteláo e o Cáo (Hsr. 122, СH. 155)}

$\mathrm{O}$ cão de um hortelão caiu num poço. Ora, querendo o hortelão tirá-lo, meteu-se lá dentro. Mas o cão, nervoso, quando o outro se aproximou dele, julgando que o ia afundar mais, mordeu-o. Então o hortelão, maltratado, disse: "É justo o que me acontece, pois se tu próprio te lançaste, porque tentei eu tirar-te do perigo?"

Para o homem ingrato e que age mal para com os seus protectores. 


\section{O citaredo (Hsr. 123, Сh. 156)}

Um citaredo inapto cantava constantemente dentro de uma casa bem rebocada. Como o som ecoava ${ }^{36}$, convenceu-se que tinha uma bela voz. Então, envaidecido disso, resolveu apresentar-se no teatro. Contudo, ao entrar em cena, como cantava mal, expulsaram-no à pedrada.

Da mesma forma, também alguns oradores que na escola parecem ser alguém, quando chegam à carreira política, revelam-se uns incapazes. ${ }^{37}$

\section{Os ladróes e o galo (Hsr. 124, Сн. 158)}

Uns ladrōes, tendo entrado numa casa, como não encontraram nada para além de um galo, pegaram nele e foram-se embora. Este, estando a ponto de ser sacrificado, rogou-lhes que o soltassem, alegando ser útil aos homens, pois à noite despertava-os para irem trabalhar. Ora os ladróes, em resposta, disseram: "Mas é sobretudo por isso que te matamos, pois ao acordá-los impedes-nos de roubar.

A fábula mostra que o que mais incomoda os malvados é aquilo que beneficia os honrados.

${ }^{36}$ Este passo pretende sugerir a qualidade acústica do lugar e considerar um efeito sonoro, adulterador, que este teria na voz do citaredo.

${ }^{37}$ Como sucede com outras fábulas aqui traduzidas, a maioria das referências culturais ou dados históricos são difíceis de localizar no tempo e na cultura original, uma vez que partem de uma tradição que se pretende generalista e abrangente na sua aplicação. Neste passo concreto, está em causa a leccionaçáo da retórica, ciência indispensável na a ascensáo do político na Grécia antiga; todavia, trata-se de uma generalização, pelo que não nos é possível identificar o contexto específico. 


\section{A gralha e os corvos (Hsr. 125, CH. 161)}

Uma gralha que se destacava das demais em tamanho, desprezando os da sua espécie, foi até junto dos corvos e pediu-lhes que a deixassem viver com eles. Mas os corvos, não familiarizados com a sua aparência e grasno, expulsaram-na à pancada. E esta, escorraçada por eles, voltou para junto das gralhas que, indignadas pela desconsideração dela, não a quiseram acolher. Assim, aconteceu ser excluída de ambos os grupos.

Da mesma forma, também os homens que abandonam a pátria e preferem outra terra, ali são desconsiderados por serem estrangeiros; e mais, são rejeitados pelos seus camaradas por os terem desdenhado.

\section{O corvo E a raposa (Hsr. 126, CH. 165)}

Um corvo que roubara carne poisou numa árvore. Ora, uma raposa que o viu e quis apoderar-se do naco, parou diante dele e começou a elogiar-lhe o porte distinto e a beleza. Acrescentou também que, em boa verdade, merecia reinar sobre as aves e que isso aconteceria certamente, se ele tivesse voz (para isso).

Então o corvo, querendo mostrar-lhe que também tinha voz, largou a carne e pôs-se a corvejar alto. De imediato a raposa se apressou a apanhar a carne e disse: "Ó corvo, se tivesses também esperteza, não te faltaria nada para reinares sobre todas as aves."

É para o homem insensato que a fábula é oportuna. 


\section{A gralha e o corvo (Hsr. 127, Сh. 170)}

A gralha, invejosa do corvo, por este prever e anunciar o futuro dos homens através de presságios e, por essa razão, o convocarem a testemunhar, quis conseguir o mesmo. Então, ao ver uns caminhantes que passavam, pousou numa árvore e soltou enormes grasnidos. Os viajantes voltaram-se assustados pelo ruído, até que um deles disse: "Sigamos caminho, companheiros, pois é uma gralha e os seus gritos nada pressagiam."

Da mesma forma, os homens que competem com os mais fortes, não só não os conseguem igualar, como ainda se tornam alvo de troça.

\section{A gralha e a Raposa (Hsr.128, Ch. 160)}

Uma gralha esfomeada pousou numa figueira. Contudo, ao dar-se conta que os frutos ainda não estavam maduros, ficou ali à espera até que se criassem. Ora uma raposa, ao constatar a longa espera da gralha e percebendo a causa, disse: "Pois estás enganada, minha cara, ao devotares-te tal esperança, que apascenta papalvos ${ }^{38}$, mas de maneira alguma alimenta.

É para o homem mentiroso que a fábula é apropriada.

\section{A gralha e o cáo (Hsr. 129, Сh. 127)}

Uma gralha, que ofereceu um sacrifício a Atena, convidou um cão para o festim ${ }^{39}$. E este disse-lhe: "Porque consomes inutilmente recursos em sacrifícios? Uma vez que a

${ }^{38}$ Optou-se pelo o uso de uma expressão popular, de modo a adequar-se ao significado de numa tradução literal.

${ }^{39}$ De notar que em causa estão dois animais necrófagos, pelo que é possível notar aqui a concepção do ambiente natural destes dois animais, apesar do contexto fantasioso. 
deusa te odeia tanto ao ponto de privar os teus presságios de credibilidade." E a gralha respondeu: "Pois por isso lhe ofereço sacrifícios, por sabê-la hostil, a fim de que se reconcilie."

Da mesma forma muitos, por medo, não hesitam em favorecer os inimigos.

\section{O CORVo e A SERPENTE (Hsr. 130, Сh. 167)}

Um corvo procurava comida e, quando viu uma serpente a dormir em lugar soalheiro, picou sobre aquela e arrebatou-a. Mas ela virou-se e mordeu-o. O corvo, prestes a morrer, disse: "Ó mísero que sou, eu que encontrei petisco tal que por causa dele pereço!"40

Esta fábula poderia aplicar-se a um homem que, por encontrar um tesouro, também póe em risco a própria vida.

\section{A gralHa e os pombos (Hsr. 131, С . 163)}

Uma gralha, tendo visto num pombal uns pombos bem nutridos, descolorou a plumagem e preparou-se para tomar parte da comida deles. E tanto manteve o bico calado que os pombos a aceitaram, julgando ser ela própria um pombo. Mas quando a certa altura se distraiu e soltou um grasnido, os pombos, como não conheciam aquele som, correram com ela. A gralha, ao perder o alimento que ali havia, voltou novamente para junto das outras gralhas. Porém, estas não a reconheceram por causa da sua cor e também a expulsaram de junto de si e da comida. E assim, por procurar dois sítios onde obter alimento, não conseguiu nenhum.

${ }^{40}$ Esta fábula nota a imagem paradigmática da serpente, cujo simbolismo de perfídia é praticamente transversal a todas as culturas antigas. 
Na verdade, também nós devemos contentar-nos com o que temos, considerando que a ganância não serve para nada e muitas vezes deita a perder o que se possui.

\section{O estômago e os PÉs (Hsr. 132, CH. 159)}

O estômago e os pés discutiam sobre o seu poder. Entre outras coisas, os pés alegavam que se superiorizavam tanto em vigor, que até carregavam o próprio estômago. E este respondeu: "Mas olha que esta! Se eu não ingerisse alimento, vós também não serieis capazes de me carregar."

Da mesma forma, também de nada vale um grande número nos exércitos, se os generais não planearem a melhor estratégia.

\section{A gralha fugida (Hsr. 133, Сh. 164)}

Um homem que capturara uma gralha atou-lhe um fio de linho à pata e deu-a ao seu filho. Mas a gralha, como não suportava a vida entre homens, aproveitou um momento de descuido, escapou e voltou ao seu ninho. Todavia, como o fio se enredasse nos ramos, não conseguia voar. Quando estava a ponto de morrer, disse para si: "Ó desgraçada de mim! Por não aguentar a escravidão entre os homens, sem me aperceber, hipotequei eu mesma a liberdade."

Esta fábula podia aplicar-se àqueles homens que, querendo livrar-se de perigos ligeiros, sem dar-se conta, caiem em desgraças maiores.

\section{O CẤo PERSEGUidor do LEẤ (HsR. 135, CH. 187)}

Um cão de caça viu um leão e perseguia-o. Mas, quando ele se virou e rugiu, assustado, recuou em fuga. Então, uma raposa que o observava disse: "Ó cabeça maluca, tu persegues 
um leão, mas nem sequer aguentas o seu rugido."

A fábula poderia contar-se a propósito dos homens estouvados que se póem a acusar os que são muito mais fortes do que eles mesmos, mas que, quando eles os enfrentam, recuam de imediato.

\section{O cáo que trazia um naco de carne (Hsr. 136, Сh. 185)}

Um cão, que trazia um naco de carne, atravessava um rio e, ao ver o seu próprio reflexo na água, julgou ser outro cáo que tinha um pedaço de carne maior. Por isso, deixou cair o seu e dispôs-se a apanhar o do outro. Mas aconteceu que ficou sem os dois, pois não conseguiu um, porque nem sequer existia, e o outro porque o rio o levou.

Para o homem ambicioso, a fábula é oportuna.

\section{O Cáo Adormecido E O LOBo (HsR. 137, CH. 184)}

Um cão dormia diante de um curral. E, um lobo ao vê-lo, concebeu a ideia de que era possível devorá-lo. Mas o cão suplicou-lhe, quando (o outro) chegou, para o libertar, dizendo: "Agora estou magro e fraco, mas os meus donos estáo em vias de fazer uma boda; se na verdade me soltares agora, mais tarde devorar-me-ás mais gordo.” Então, persuadido por ele, o lobo soltou-o.

Alguns dias depois, voltou e como o visse a dormir dentro de casa, chamou por ele recordando-lhe o acordo. Mas ele disse retorquindo: "Pois, meu caro lobo, se de novo me vires a dormir diante do curral, náo esperes mais pelas bodas."

Desta forma os homens sensatos, cada vez que escapam a algum perigo, mais tarde fazem-se avisados para ele. 


\section{Os cáes famintos (Hsr. 138, Сн. 176)}

Uns cães famintos viram num rio umas peles ensopadas ${ }^{41}$ e, como não conseguiam chegar-lhes, combinaram entre si, primeiro, beber a água, e depois, desse modo, agarrar as peles. Contudo, sucedeu que, de tanto beberem, rebentaram antes de as alcançarem.

Da mesma forma alguns homens, na espectativa de lucro, metem-se em trabalhos perigosos e acabam por tramar-se antes de lograrem aquilo que pretendiam.

\section{O Cấo e a lebre (Hsr. 139, СH. 182)}

Um cão de caça, que tinha uma lebre, ora a mordia, ora lhe lambia o focinho. Então a lebre, farta, disse-lhe: "Meu caro, pára de me morder ou de me beijar para que eu saiba se és meu inimigo ou amigo."

Para o homem ambíguo a fábula é oportuna.

\section{O mosquito E O touro (Hsr. 140, Сн. 189)}

Um mosquito pousou num corno de um touro e por aí ficou por muito tempo. Mas quando estava para se afastar, perguntou ao touro se queria que se fosse embora. Ora o touro disse em resposta: "Mas se nem quando tu chegaste eu dei por ti, também não darei quando te fores."

Esta fábula podia aplicar-se ao homem insignificante

${ }^{41}$ Uma vez humedecidas as peles, os tecidos ensopados dilatam-se, levando os cáes a considerar serem carcaças. Pode subentender-se neste passo uma técnica de curtição, dado que depois de esfolados os animais, era costume mergulhar-se os tecidos em água a fim de os amaciar e de os tornar mais flexíveis (vide Habermann 1990 e Wild 2002) 
que, quer esteja presente, quer esteja ausente, não é nem nocivo nem útil.

\section{As lebres E AS RẤS (HsR. 143, CH. 191)}

Quando as lebres se aperceberam da sua cobardia, decidiram ser necessário despenharem-se e foram até um precipício ao fundo do qual havia um charco. Então, umas rãs, tendo ouvido o barulho de passos, lançaram-se para o fundo do charco. E uma lebre, que as viu, disse às outras: "Mas já não temos que nos atirar, pois veja-se, existem animais mais cobardes do que nós."

Da mesma forma, os homens consolam o seu próprio infortúnio com as desgraças alheias.

\section{A gaivota E o milhafre (HsR. 144, CH. 193)}

Uma gaivota, que tinha estoirado as goelas por ter engolido um peixe, jazia morta no areal. E um milhafre que a viu disse: "Foi justo o que te aconteceu, pois tendo tu nascido pássaro, procuravas sustento no mar."

Da mesma forma, os que abandonam as suas próprias ocupaçóes e se dedicam a outras que não lhes dizem respeito, naturalmente, sofrem infortúnios.

\section{O leáo apaixonado (Hsr. 145, CH. 198)}

Um leão, apaixonado pela filha de um lavrador, pediu-a em casamento. Mas este, não se atrevendo a entregar a filha a uma fera, nem sendo capaz de recusar, por causa do medo, congeminou o seguinte: sempre que o leão o pressionava insistentemente, dizia que o aprovava como noivo digno da filha, mas simplesmente não poderia entregar-lha se não arrancasse os dentes e se não cortasse as garras; é que isso 
assustava a rapariga. E como ele facilmente, por causa do amor, se submeteu às duas exigências, o lavrador perdeu-lhe o respeito e, quando o leão se apresentou perante ele, deu-lhe com o cajado e afugentou-o.

A fábula mostra que os que facilmente confiam nos vizinhos, sempre que renunciam à sua própria superioridade, tornam-se presa para aqueles que anteriormente, temerosos, se submetiam.

\section{O LeÃo e a rấ (HsR. 147, CH. 201)}

Um leão, ao ouvir uma rã a coaxar, virou-se para o local de onde vinha o som, julgando ser um grande animal. Mas esperou por ele um pouco e, quando a viu sair do charco, aproximou-se e pisou-a, dizendo: "Que nada perturbe o ouvido antes da vista!"

Para o homem incapaz de nada mais do que falar, a fábula é oportuna.

\section{O leão enVelhecido E A raposa (Hsr. 147, CH. 196)}

Um leão envelhecido e incapaz de, pelo seu vigor, providenciar alimento, pensou obtê-lo através do engenho. Então, foi para uma caverna e aí reclinado fingia estar doente. E desse modo agarrava os animais que se aproximavam dele para o visitar e devorava-os. Comidos já muitos animais, uma raposa, que percebeu o seu artifício, apresentou-se e, permanecendo fora da caverna, perguntou-lhe como estava. "Mal" - disse o leão. E, ao inquirir a razão para ela não entrar, a raposa respondeu: "Eu, de facto, entraria, se não visse as pegadas de muitos a entrar, mas de nenhum a sair."

Da mesma forma, os homens sensatos, ao perceber os perigos pelos seus indícios, evitam-nos. 


\section{O leấo e O touro (Hsr 148, Сh. 111)}

Um leão maquinava contra um touro enorme e quis superá-lo por meio de engano. Por isso, com a alegação de ter morto uma ovelha, convocou-o para um banquete, na intenção de o vencer quando estivesse reclinado.

Mas este, ao chegar e observar muitos caldeiróes e grandes espetos, mas nenhuma ovelha, sem dizer nada abalou. E, quando o leão o censurou e inquiriu sobre a causa pela qual, não se tendo passado nada de desagradável, se ia embora sem palavra, disse: "Mas eu não faço isto sem motivo. Pois, é que não vejo preparativos para uma ovelha, antes arranjo para um touro."

A fábula mostra que aos homens sensatos as artimanhas dos malvados não passam despercebidas.

\section{O LeÁo APrisionado E O LAVRAdor (Hsr. 149, Сн. 197)}

Um leão entrou no estábulo de um lavrador. Este, querendo apanhá-lo, fechou a porta do curral. E o leão, como não conseguia sair, primeiro devastou o rebanho e, em seguida, saciou-se também nos bois. Então, o lavrador, temendo pela sua pessoa, abriu a porta.

Libertado o leão, a mulher, ao ver o mesmo lamentarse, disse: "Mas tu sofreste o que é justo, pois porque quiseste tu reter aquele que até ao longe devias temer?"

Dessa forma, os que provocam os mais fortes, naturalmente submetem-se aos seus próprios erros. 


\section{O LeÃo E O gOlfinho (HsR. 150, СH. 202)}

Um leão vagueava pelo prado e, quando viu um golfinho a emergir a cabeça, convidou-o a fazerem uma aliança, dizendo-lhe que era muito apropriado tornarem-se amigos e colaboradores. Com efeito, um reinava sobre os animais marinhos e o outro sobre os terrestres. E, acolhida a proposta de bom grado, o leão, não muito tempo depois, ao travar um combate com um touro selvagem, pediu auxílio ao golfinho. Todavia, como ele, ainda que o quisesse, não foi capaz de sair do mar, o leáo acusou-o de traidor. O golfinho, porém, respondeu e disse: "Ora essa, não me culpes a mim, antes a natureza, que me fez marinho e náo me permite pisar a terra."

Por isso, também nós, ao selar uma amizade, devemos escolher aliados, que sejam capazes de nos socorrer nos perigos.

\section{Leấo assustado por um rato (Hsr. 152, Сh. 213)}

Quando um leão dormia, correu-lhe um rato sobre a barriga. Entâo, ele levantou-se e procurou por todas as partes quem o atacara. Uma raposa que o observava censurou-o por, leão que era, ter medo de um rato. Ele, porém, replicou: "Não é um rato que me assusta, mas espanta-me que alguém se tenha atrevido a correr sobre o corpo de um leão."

A fábula ensina que os homens sensatos não devem desprezar as coisas modestas.

\section{O LEÁo e O URSO (HsR. 152, СН. 200)}

Um leão e um urso encontram a cria de um veado e lutavam por ela. E tão ferozmente se atacaram um ao outro, que se cegaram e tombaram meio-mortos. Entấo, uma 
raposa que se encontrava por ali, quando os viu caídos e o cervo que jazia no meio deles, pegou neste e afastou-se por entre os dois. E eles, incapazes de se levantarem, exclamavam: "Miseráveis de nós, que nos afadigámos para uma raposa."

A fábula mostra que com razão se queixam aqueles que vêem os recém chegados levar o fruto do seu próprio trabalho.

\section{O LeÃo E A Lebre (HsR. 153, СH. 204)}

Um leão encontrara por acaso uma lebre a dormir e preparava-se para a comer. Porém, entretanto, ao lobrigar um veado próximo, largou a lebre, e perseguiu-o. E a lebre, acordada pelo barulho, fugiu. Ora, o leão, depois de muito correr atrás do veado, como não conseguiu alcançá-lo, voltou-se para a lebre. Mas, ao verificar que também ela tinha fugido, disse: "Pois eu sofri o que é justo, porque larguei a comida que tinha entre mãos para preferir a esperança numa maior."

Da mesma forma, alguns homens insatisfeitos com lucros moderados perseguem maior esperanças e, sem perceberem, perdem o que têm entre mãos.

\section{O Leấo, o burro e raposa (Hsr.154, CH. 209)}

Um leão, um burro e uma raposa, celebrado um pacto de sociedade entre eles, saíram para caçar. Apanhadas muitas reses, o leão ordenou ao burro que as dividisse. Este fez três lotes e exortou-o a escolher. Irritado, o leão lançou-se para ele e devorou-o; seguidamente ordenou à raposa que repartisse. Então, ela, juntando tudo numa única parte e deixando para si uma pequena porção, exortou-o a escolher. E, quando o 
leão lhe perguntou quem a ensinou a dividir dessa maneira, a raposa retorquiu: "A desgraça do burro!"

A fábula mostra que, para os homens, a prudência nasce do azar do próximo.

\section{O leấo e o rato reconhecido (Hsr.155, Ch. 206)}

Enquanto um leão dormia, um rato corria sobre o seu corpo. Então ele levantou-se, agarrou-o e estava mesmo a ponto de o devorar. Mas o rato pediu-lhe para o libertar e disse que, se fosse poupado, the retribuiria o favor. $\mathrm{O}$ leão riu e soltou-o. E aconteceu que ele, não muito tempo depois, viria a ser salvo pelo favor do rato. É que, quando o leão foi apanhado por uns caçadores que o prenderam a uma árvore com uma corda, o rato, ao ouvir então o leão a lamentar-se, acercou-se, roeu a corda e libertou-o dizendo: " $\mathrm{Tu}$, no passado, zombaste de mim daquela forma, porque não admitias que eu viesse a retribuir o favor. Pois fica agora a saber que também entre os ratos existe gratidão.'

A fábula mostra que, nas voltas da fortuna, os mais fortes podem tornar-se dependentes dos mais fracos.

\section{O LeÁo E O BURRo QUe CAÇAM JUNTOS}

\section{(HsR. 156, Сн. 208)}

Um leão e um burro acordaram um pacto entre eles e saíram para caçar. E chegados a uma caverna onde havia cabras selvagens, o leâo à entrada cuidava das que saíssem, enquanto o burro, entrando nela, saltou e zurrou, na intenção de as assustar. E após o leão ter apanhado a maioria, o aliado saiu e inquiria-o se lutara com bravura e se as perseguira de forma correcta. E o outro disse: "Pois fica bem certo de que eu próprio de ti fugira, se não soubesse que és um burro." 
Dessa forma, os que se alardeiam diante de quem os conhece, com razão se expóem ao ridículo.

\section{O CRIMINoso E A AMOReIRA (Hsr. 157, С . 214)}

Um criminoso matou um homem num carreiro e, quando se viu perseguido pelos que por ali andavam, fugiu ensanguentado, abandonando a vitima. Ora, quando uns caminhantes que vinham em sentido contrário the perguntaram porque tinha as mãos manchadas, disse que acabara de derrubar uma amoreira. E enquanto dizia isto, aqueles que o perseguiam chegaram ali e, tendo-o apanhado, penduraram-no numa amoreira. E a amoreira disse-lhe: "Pois não me custa contribuir para a tua morte, porque depois de teres cometido o crime, querias desculpar-te comigo."

Da mesma forma, os de boa natureza, quando são caluniados por alguns, não hesitam em portar-se mal para com eles.

\section{Os lobos e as ovelhas (HsR. 158, Сн. 217)}

Uns lobos que tinham tramas contra um rebanho de ovelhas, já que não eram capazes de as apanhar por causa dos cães que as guardavam, concluíram ser necessário consegui-lo através de um dolo. E enviaram embaixadores a pedirem os cães delas, alegando que eram os responsáveis pela sua inimizade e que, se os entregassem, surgiria paz entre eles. Ora, as ovelhas, não prevendo o que lhes estava destinado, entregaram os cães. Então os lobos venceram-nos rapidamente e dizimaram o rebanho que estava desprotegido.

$\mathrm{Da}$ mesma forma, as cidades que abandonam facilmente os seus líderes não percebem cair nas mãos dos inimigos de imediato. 


\section{O lobo e O cavalo (Hsr. 19, Сн. 225)}

Um lobo, ao passear por um campo, encontrou cevada. Incapaz de a usar para comer, abandonou-a e foi-se embora.

Mas, ao deparar com um cavalo, levou-o até ao campo e disse-lhe que, ao encontrar cevada, não a comeu, antes a guardou para ele e que, por outro lado, ouve com prazer o barulho dos dentes dele. Então o cavalo disse em resposta: "Mas, meu caro, se os lobos pudessem utilizar cevada como alimento, nunca terias preferido os ouvidos ao estômago."

A fábula mostra que os maus por natureza, ainda que se proclamem os mais honrados, não são de confiança.

\section{O LOBO E O CORDEIro I (Hsr. 160, Сн. 221)}

Um lobo viu um cordeiro junto de um rio a beber e sentiu desejo de o devorar com motivo razoável. Por isso, apesar de estar postado mais acima, acusou-o de turvar a água e não lhe permitir beber. $\mathrm{E}$ como o cordeiro lhe respondeu que bebia com a ponta dos lábios e que, além disso, não lhe era possível, por estar mais abaixo, agitar a água em ponto superior. O lobo, ao falhar esse motivo, disse: "Mas, há um ano insultaste o meu pai." E como ele dissesse que "há um ano nem era nascido." O lobo retorquiu-lhe: "Mesmo que te escudes em discursos de defesa, ainda assim vou devorar-te.

A fábula mostra que, contra quem tem vontade de ser injusto, nenhuma defesa justa prevalece. 


\section{O LOBO E GARÇA (Hsr. 161, Сh.224)}

Um lobo, ao engolir um osso, andava em busca de cura. Então encontrou-se com uma garça e pediu para ela lhe tirar o osso, mediante pagamento. A garça, enfiando a cabeça pela garganta do lobo, tirou o osso e reclamou o pagamento acordado. Mas ele, em resposta disse: "Ó minha cara, não te chega teres tirado a cabeça a salvo da boca do lobo, mas ainda pedes pagamento?"

A fábula mostra que, da parte dos malvados, a maior recompensa para uma boa acção é não sofrer dano.

\section{O lobo e a CABRa (HsR. 162, Сн. 220)}

Um lobo viu uma cabra a pastar num barranco e, como não foi capaz de chegar até ela, incitou-a a vir mais para baixo, não fosse cair por descuido; dizia que o prado junto dele era melhor, pois a erva era mais viçosa e abundante. Ela, porém, respondeu-lhe: "Mas tu não me chamas pelo pasto, mas por teres falta de comida."

Da mesma forma, os homens perversos, sempre que actuam mal contra quem os conhece, tornam inúteis as suas artimanhas.

\section{O lobo e a Velha (HsR. 163, Сн. 223)}

Um lobo faminto vagueava em busca de comida. Quando chegou a certa quinta, ouviu uma velha a ralhar violentamente com uma criança que chorava: que se não parasse, a atirava ao lobo. E ele esperou pensando que ela falaria verdade. Chegando a tarde, como nada acontecia condizente com as palavras, partiu e disse para si próprio: "Nesta quinta os homens dizem uma coisa e fazem outra." 
Esta fábula aplica-se àqueles homens que às palavras não adequam os actos.

\section{O lobo e a OVelha (Hsr. 164, Сн. 230)}

Um lobo saciado de comida, ao ver uma ovelha lançada por terra e ao perceber que se escondera por medo dele, aproximou-se e encorajou-a dizendo que, se lhe contasse três verdades, a libertaria. Então, ela começou e disse em primeiro lugar que não desejava encontrá-lo; em segundo lugar, já que tal aconteceu, (preferiria) encontrá-lo cego; em terceiro lugar, disse: "Sejais todos destruídos de forma terrível, malditos lobos, que sem terem sofrido algum mal da nossa parte, nos fazeis guerra!" Então o lobo, aprovando a sua sinceridade, deixou-a partir incólume.

A fábula mostra que muitas vezes a verdade prevalece mesmo entre inimigos.

\section{O lobo ferido E a ovelha (Hsr. 166, Сн. 231)}

Um lobo, ferido por cães e muito mal tratado, jazia incapaz de procurar comida para si. Então viu uma ovelha e pediu-lhe para lhe trazer de beber de um rio que corria perto: "É que se tu me deres bebida - disse ele - eu mesmo encontrarei alimento." Então a ovelha disse em resposta: "Se eu te der de beber, tu também me utilizarás como comida."

É para o homem perverso que actua pelo embuste que a fábula é oportuna 


\section{O ADIVINHo (HsR. 170, СH. 233)}

Um adivinho ganhava a vida, estabelecido na ágora ${ }^{42}$. Nisto, uma certa pessoa aproximou-se dele e comunicoulhe que as portas da sua casa estavam abertas e que tinham levado tudo o que estava lá dentro. Fora de si, deu um salto e, lamentando-se, pôs-se a caminho a fim de averiguar o que sucedera. E um dos que estava por ali, ao vê-lo, disse: "Então tu, dedicavas-te a prever as coisas dos outros e não adivinhaste o que te aconteceria?"

Podia aplicar-se esta fábula àqueles que administram a sua vida de modo descuidado, mas que se metem nos assuntos que em nada lhes dizem respeito.

\section{A CRIANÇA E O CORVo (HsR. 171, CH. 294)}

Uma mulher consultou uns adivinhos sobre o seu filho, ainda pequeno, e estes previram que seria morto por um corvo. Por isso, assustada, preparou um grande baú e meteu ali a criança de modo a impedir que um corvo a matasse. Todos os dias abria-o a determinadas horas $\mathrm{e}$ providenciava-lhe a comida necessária. Certo dia, abriu-o, deixando a tampa levantada; o menino ergueu-se de modo atabalhoado e assim ocorreu que a tranca ${ }^{43}$ do baú caiu-lhe sobre a moleirinha e o matou.

A fábula mostra que aquilo que está fadado é inevitável.

${ }^{42}$ No que refere à toponímia da cidade, a ágora (’’yopá) seria o espaço de confluência da actividade política, social, religiosa e económica da polis, pelo que aí se encontraria o principal mercado da cidade (vide Hoepfner \& Schwandner 1986).

${ }^{43} \mathrm{O}$ termo grego kó $\alpha \propto \xi(\breve{\alpha \kappa o c) ~ e ́ ~ o ~ m e s m o ~ p a r a ~ o ~ a n i m a l, ~ c o r v o, ~ e ~}$ para o conceito de fecho mecânico, pelo que está em causa a ambiguidade de uma previsão e a interpretação errónea: a mãe julgou que o potencial assassino seria um corvo (ave). 


\section{As abelhas E Zeus (Hsr. 172, Сн. 234)}

As abelhas, furiosas com os homens pelo espólio do seu mel, foram até Zeus a fim de lhe pedir que lhes concedesse força suficiente para golpear com os seus aguilhôes os que roubavam os seus favos. Ora, Zeus, irritado pela perversidade delas, fez com que, caso picassem alguém, perdessem o aguilhão e depois morressem.

Esta fábula ajustar-se-ia aos homens maus, que aceitam eles próprios sofrer o mal que fazem.

\section{Os menargitas ${ }^{44}$ (Hsr. 173, Сh. 236)}

Uns menargitas, que tinham um burro, costumavam carregá-lo com as suas trouxas quando iam de viagem. Porém um dia, como o burro morresse de cansaço, esfolaramno e com a pele dele fizeram uns pandeiros ${ }^{45}$ de que se serviram. Quando outros sacerdotes, que os encontraram, lhes perguntaram onde estava o burro, responderam que morrera e que, agora, levava tanta pancada como nunca tinha aguentado em vida.

Da mesma forma, alguns servos, mesmo libertos da escravidão, não estão livres dos trabalhos de escravos.

\section{Os ratos e as doninhas (HsR.174, С . 237)}

Os ratos e as doninhas estavam em guerra. Porém, os ratos, constantemente derrotados, reuniram-se em assembleia, pois julgavam que isso acontecia por falta de

${ }^{44}$ Sacerdotes mendicantes da deusa Cibele.

${ }^{45}$ Tú $u \pi \alpha v o v$ : instrumento de precursão. 
líderes. Portanto, tendo escolhido alguns de entre eles, aclamaram-nos. Aqueles, como queriam destingir-se do resto dos ratos, equiparam-se com cornos e ajustaram-nos. Contudo, travada a batalha, aconteceu que os ratos foram derrotados. Porém, quando os demais procuraram refúgio nos buracos, onde cabiam facilmente, os generais, não sendo capazes de entrar por causa dos cornos, foram capturados e devorados.

Da mesma forma, a vaidade é a causa das desgraças.

\section{A formiga (HsR. 175, Сh. 242)}

A formiga dos dias de hoje foi no passado um homem, que trabalhava no campo e não se contentava com os ganhos do seu próprio trabalho, ao contrário, cobiçava o dos outros e frequentemente roubava os frutos dos vizinhos. E Zeus, chateado com a ganância daquele, transformou-o neste animal, ao qual se dá o nome de formiga.

Contudo, apesar de ter mudado de aspecto, náo se alterou o seu carácter. De tal modo que agora, ao deambular pelos campos, colhe e guarda para si o trigo e a cevada dos outros.

A fábula mostra que os que são de natureza perversa, ainda que sejam castigados, não alteram a sua forma de ser.

\section{A mosca (HsR. 177, Сн. 238)}

Uma mosca que caiu numa panela de carne, estando a ponto de se afogar no molho, disse para si mesma: "Pois bem, comi, bebi e tomei banho; ainda que morra, náo me importo."

A fábula mostra que as pessoas suportam mais facilmente a morte, se esta chega sem sofrimento. 


\section{O náufrago e o mar (Hsr. 178, С . 245)}

Um náufrago que deu à costa perdeu os sentidos por causa do esforço. Mais tarde, acordou e, quando mirou o mar, vituperou-o por seduzir os homens com o seu aspecto sereno, porém, depois de os receber, tornar-se selvagem e fazê-los perecer. O mar, tomando a forma de mulher, disse-lhe: "Mas não me culpes a mim, antes aos ventos, porque a minha natureza é tal e qual a que vês agora, eles é que caem sobre mim, revolvem-me em ondas e enfurecem-me.

Da mesma forma também nós não devemos culpar pelas más acçôes os que as cometem, quando eles obedecem às ordens de outros, mas antes aqueles que as motivam.

\section{O JOVem libertino E A ANdorinha (HsR. 179, $\mathrm{CH}$.}

\section{8)}

Um jovem libertino, depois de devorar a fortuna paterna, apenas possuía um manto. E como viu uma andorinha que migrara antes do tempo, julgou ter chegado o verão e que não precisaria do manto, pelo que agarrou nele e vendeu-o. Mais tarde, porém, tendo chegado o inverno e fazendo muito frio, enquanto deambulava viu a andorinha morta e enregelada e disse-lhe: "Ó tu aí! Pois levaste-me à perdição, a mim e a ti."

A fábula mostra que tudo o que se faz fora de tempo resulta pernicioso.

\section{O doente E O MÉDico (HsR. 180, Сн. 249)}

Um doente, a quem o médico perguntava como estava, respondeu que suava mais do que o normal. O médico disse: "Isso é bom". Ao perguntar pela segunda 
vez como estava, respondeu que tinha sido sacudido por calafrios. O médico disse novamente que aquilo era bom. À terceira, quando apareceu o médico a perguntar-lhe pela sua maleita, respondeu que tivera diarreia. $\mathrm{O}$ médico disse não haver problema nisso e foi-se embora. Ora, quando um dos seus familiares o foi visitar e lhe perguntou como passava, disse-lhe: "Eu morro de tão bem que estou."

Assim, muitos homens são considerados felizes pelo próximo por causa da aparência de coisas que causam um sofrimento interior.

\section{O MORCEGO, O ESPINHEIRO E A GAIVOTA (HsR. 181, СH. 250)}

Um morcego, um espinheiro e uma gaivota, tendo-se posto de acordo, decidiram dedicar-se ao comércio. Portanto, o morcego pediu dinheiro emprestado e depositou-o num fundo comum, o espinheiro deixou as roupas e a gaivota comprou cobre e entregou-o. Depois fizeram-se ao mar. Todavia, quando se desencadeou uma violenta tempestade e o barco se afundou, eles chegaram salvos a terra, mas perderam tudo. Por isso, desde então, a gaivota busca pela costa o cobre, julgando que um dia o encontrará; o morcego, por temor dos credores, não se mostra durante o dia e sai à noite em busca de comida. $\mathrm{O}$ espinheiro, procurando as roupas, engancha-se nos mantos dos caminhantes, tentando reconhecer o seu.

A fábula mostra que é por aquilo que mais nos interessa que primeiro perecemos. 


\section{O MORCEgo E as doninhas (Hsr. 182, С . 251)}

Um morcego, que caiu ao chão, foi apanhado por uma doninha. E estando a ponto de morrer, pediu que lhe poupasse a vida. Como esta afirmasse não o soltar, pois, por natureza, combatia todos os voadores, ele disse não ser pássaro, mas um roedor, e assim safou-se. Contudo, mais tarde voltou a cair e foi novamente capturado por uma doninha, à qual pediu que o deixasse. Mas como esta dissesse ser inimiga de todos os ratos, ele respondeu que não era um rato, antes um morcego e libertou-se novamente. Pois assim aconteceu que, por mudar duas vezes de nome, logrou salvar-se.

Deste modo, não devemos insistir sempre nos mesmos meios, tendo presente que aqueles que se adaptam às circunstâncias, a miúde escapam do maiores perigos.

\section{O lenhador e Hermes (Hsr. 183, СH. 253) (6 $^{46}$}

Um homem que cortava lenha junto a um rio perdeu o machado. Ora o homem, sentado na margem, lamentavase até que Hermes se compadeceu dele e apareceu-lhe. Ao saber do próprio lenhador o motivo do choro, Hermes trouxe-lhe primeiro um machado de ouro e perguntoulhe se aquele era o seu. E como aquele dissesse náo ser, à segunda vez trouxe-lhe um de prata e novamente perguntou se era o que tinha perdido e o lenhador negou. À terceira vez trouxe-lhe o machado dele e aquele reconheceu-o. Hermes, contente com a honestidade daquele, ofertou-lhe todos. $\mathrm{O}$ lenhador foi-se embora e quando regressou para junto dos companheiros contou-lhes o que acontecera. E um deles, deslumbrado, quis obter o mesmo. Logo que tomou

${ }^{46}$ A propósito da origem pré-histórica desta fábula vide Cons 1924. 
o machado, foi até ao mesmo rio. Então, quando cortava lenha, deixou cair o machado de propósito e, sentado, pôs-se a chorar. Entretanto, como Hermes lhe aparecesse e perguntasse o que tinha acontecido, disse ter perdido o machado. Ora, o deus trouxe-lhe um de ouro e perguntou se era o que tinha perdido; por causa da cobiça, precipitouse e disse que sim. Então o deus, não só não o agraciou, como não lhe devolveu o seu.

A fábula mostra que a divindade, da mesma maneira que ajuda os honestos, prejudica os desonestos.

\section{O viajante E a fortuna (Hsr. 184, CH. 261)}

Um viajante, depois de ter feito um longo caminho, moído pelo cansaço, tombou junto a um poço e adormeceu. Estava a ponto de cair, quando a Fortuna ${ }^{47}$ se aproximou e, ao acordá-lo, disse: "Ora tu, se acaso tivesses caído, não atirarias culpas à tua insensatez, mas a mim.”

Da mesma forma, muitos homens caídos em desgraça, por culpa própria, acusam os deuses.

\section{Os viajantes E O PlÁtano (HsR. 185, CH. 257)}

No verão, uns viajantes, atormentados pelo calor do meio dia, ao ver um plátano, refugiaram-se debaixo dele e descansavam reclinados à sua sombra. Ora, tendo um deles levantado o olhar para o plátano, disse para um outro: "Como é inútil e estéril esta árvore para os homens." E o plátano disse em resposta: "Seus ingratos! Apesar de estarem a desfrutar dos meus serviços, chamais-me inútil e estéril."

${ }^{47}$ Tradução correspondente ao conceito divinizado de Túxๆ. 
Da mesma forma, alguns homens são tão infelizes que, mesmo beneficiando o próximo, não tornam a sua utilidade credível.

\section{O Viajante e a víbora (Hsr. 186, СH. 82в)}

Um viajante seguia por um caminho durante o inverno, quando viu uma víbora enfraquecida pelo gelo e, com pena dela, pegou-lhe, colocou-a no próprio regaço e tentava aquecê-la. A víbora, enquanto estava contraída por causa do frio, estava imobilizada. Mas depois de aquecida, desferiu uma picada no ventre dele. Então, estando ele a ponto de morrer, disse: "Mas eu sofri o que é justo, pois porque poupei à morte quem também estava decidida a executar-me?"

A fábula mostra que a maldade, favorecida, não retribui a quem faz o favor e vira-se ainda contra os bem feitores.

\section{Os Viajantes E O tojo (HsR. 187, СH. 258)}

Uns viajantes que caminhavam ao longo da costa chegaram a um ponto elevado e, ao verem dali um tojo a flutuar ao longe, pensaram ser uma grande embarcação, pelo que esperaram, julgando que fosse fundear. No entanto, quando o vento empurrou o tojo e o aproximou um pouco, aguardaram com curiosidade, suspeitando já não ser um grande barco, como anteriormente. Mas quando estava mais próximo, ao comprovar que se tratava de um tojo, disseram entre si: "Esperámos em vão por uma coisa que não era nada."

Da mesma forma, algumas pessoas que ao longe parecem ser terríveis, quando são postas à prova resultam não ser dignas de coisa nenhuma. 


\section{O viajante e Hermes (Hsr. 188, Сh. 260)}

Um viajante, que percorria um longo caminho, prometeu entregar a Hermes a metade do que encontrasse como oferenda. Ora, tendo topado com um saco, dentro do qual havia amêndoas e tâmaras, apanhou-o, crendo que tinha dinheiro. Mas quando sacudiu o saco e viu o que continha, comeu o conteúdo e em seguida, ao apanhar as cascas das amêndoas e os caroços das tâmaras, foi depositá-los sobre um altar, dizendo: "Recebe, ó Hermes, o meu voto, pois reparti contigo a parte de dentro e a parte de fora do que encontrei."

Para o homem avaro que, por ganância, engana até mesmo os deuses com sofismas.

\section{O burro e O Jardineiro (Hsr. 190, С . 273)}

Um burro, que prestava serviço a um jardineiro, como comia pouco e trabalhava muito, pediu a Zeus para o livrar do jardineiro e o pôr nas mãos de outro amo. Então, Zeus enviou Hermes e pediu-lhe que o vendesse a um oleiro. Porém, também ali sofria, pois obrigavam-no a carregar muita coisa pelo que evocou Zeus outra vez. Finalmente, Zeus decidiu vendê-lo a um curtidor. E o burro, percebendo o que o seu amo fazia, disse: "Pois era melhor para mim passar fome, alombando a carga dos meus antigos amos, do que ter vindo para aqui, onde, caso morra, nem sequer terei um túmulo."

A fábula mostra que os servos sentem falta dos antigos amos, quando tomam experiência com os seguintes.

\section{O burro Que carregava sal (Hsr. 191, Сh. 265)}

Um burro, carregado com sal, atravessava um rio. Ao escorregar, caiu à água e, como parte do sal se dissolveu, levantou-se mais leve. E o burro ficou feliz com a queda. 
Noutra ocasião, ao atravessar um rio outra vez, mas carregado de esponjas, julgou que se caísse de novo se levantaria mais leve. Então, tombou propositadamente. Mas aconteceu que, tendo as esponjas absorvido água, afogou-se ali.

Da mesma forma, também alguns homens, sem dar-se conta, metem-se em desgraças por causa dos seus planos.

\section{O burro e a mula I (Hsr. 192, CH. 265)}

Um burriqueiro conduzia um burro e uma mula carregados. O burro, enquanto estava em terreno plano, aguentava o peso, porém, tendo chegado a uma colina, como não aguentava mais, pediu à mula que tomasse parte da carga, de modo a ser capaz de transportar o resto. Todavia, a mula não ligou às palavras dele e o burro despenhou-se e ficou brutalmente trucidado. O burriqueiro, sem saber o que fazer, não só pôs a carga, como ainda o burro em cima da mula, depois de esfolá-lo. Então aquela, de tal forma subjugada, disse: "Mas é bem feito, pois se tivesse aceitado aligeirar um pouco a carga ao burro, quando o pedia, não tinha agora que o carregar a ele e à sua carga.”

Da mesma forma, também alguns credores, por cobiça, ao oferecer um pouco mais aos endividados, muitas vezes perdem o próprio capital.

\section{O BURRo QUE CARREgaVA UMA ESTÁtuA}

\section{(HsR. 193, СH. 266)}

Um homem, tendo carregado um burro com a estátua de uma divindade, seguiu para a cidade. Como aqueles que passavam se prostravam em adoração à estátua, o burro, julgando que o adoravam a ele, envaideceu-se, pôs-se a zurrar e não quis avançar mais para diante. Ora, o burriqueiro, ao 
perceber o que se passava, bateu no burro com um pau e disse: "Ó imbecil! Mas era só o que faltava, um burro adorado pelos homens."

A fábula mostra que os que se vangloriam das virtudes alheias caiem no ridículo aos olhos de quem os conhece.

\section{O burro SelVagem E O doméstico (Hsr. 194, CH. 264)}

Um burro selvagem, ao ver um burro doméstico num lugar soalheiro, aproximou-se e felicitou-o pelo vigor do seu corpo e pelo pasto de que gozava. Contudo, mais tarde, ao vê-lo carregar o fardo e o burriqueiro atrás dando-lhe com o pau, disse: "Bem, já não te considero afortunado, pois vejo que tens abundância, mas não sem grandes males.”

Da mesma forma, não são invejáveis as regalias conseguidas com perigos e desgraças.

\section{O burro e as Cigarras (Hsr. 195, Сh. 278)}

Um burro, que ouviu umas cigarras a cantar, agradou-se com a melodia delas e, invejoso da sua voz, perguntou-lhes o que comiam para entonar tal canto. E como elas disseram "orvalho", o burro, ao esperar alimentar-se do orvalho, morreu à fome.

Da mesma forma, aqueles que desejam coisas contrárias à sua natureza, para além de não as conseguirem, sofrem também os maiores azares.

\section{Os burros diante de Zeus (Hsr. 196, С . 262)}

Numa certa ocasião uns burros, fartos de constantemente alombarem peso e sofrerem, enviaram embaixadores a Zeus para pedir uma certa libertação dos trabalhos. Ele, querendo mostrar-lhes que era impossível, disse que se liber- 
tariam dos seus sofrimentos quando ao urinar criassem um rio. Aqueles tomaram à letra as suas palavras e, até hoje, se vêem urina de outros, param ali também e urinam.

A fábula mostra que o destino traçado a cada um é incontornável.

\section{O bURro E O BURriqueIro (Hsr. 197, Сh. 277)}

Um burro, conduzido por um burriqueiro, adiantou-se um pouco no caminho, abandonou terreno plano e foi dar a uma escarpa. Quando estava prestes a despenhar-se, o burriqueiro, puxando-lhe o rabo, tentava fazê-lo recuar. Porém, como o burro resistisse vigorosamente, soltou-o e disse: "Vence tu! Pois levas nefasto triunfo."

Ao homem quezilento a fábula é útil.

\section{O LObo Médico (HsR. 198, СH. 281)}

Um burro que pastava num prado, quando viu que um lobo se precipitava para ele, fingiu coxear. O lobo, já próximo dele, interrogou-o sobre a razão daquele mancar; ele disse que, ao pular o cercado, pisara um espinho e pediu-lhe que primeiro o removesse para assim o poder comer sem picar-se. Quando o lobo ficou convencido e levantou a pata do burro, fixou toda a sua atenção no casco e aquele deu-lhe um coice no focinho, fazendo-lhe saltar os dentes. Ora o lobo, bastante maltratado, disse: "É justo o que me acontece, pois tendo-me o meu pai ensinado o ofício de carniceiro, porque haveria eu de tentar medicina?"

Da mesma forma, também os homens que se empenham em fazer o que não é da sua competência, naturalmente, acabam por dar-se mal. 
188. O burro disfarÇAdo CoM Pele de leÃo (HsR. 199, CH. 267) ${ }^{48}$

Um burro vestira uma pele de leão e andava por todo o lado a assustar os outros animais irracionais. E, ao avistar uma raposa, tentava também aterrorizá-la. Mas ela pois aconteceu tê-lo ouvido antes a zurrar - disse para ele: "Ora, podes bem ter a certeza de que também me assustaria contigo, se não tivesse escutado o teu zurro.”

Da mesma forma, alguns ignorantes, que parecem ser alguém pela sua vaporosa aparência exterior, são desmascarados pela sua própria tagarelice.

\section{O bURro E AS RÃS (Hsr. 201, CH. 271)}

Um burro, que levava um carrego de lenha, atravessava um charco. Ao escorregar caiu e, como não conseguia levantar-se, pôs-se a gemer e a lamentar-se. Ora, as rãs do charco, ao ouvirem-no queixar-se, disseram: “Ó este! Que farias tu se estivesses aqui há tanto tempo quanto nós, tu que caíste há pouco e gritas dessa forma?"

Esta fábula podia aplicar-se ao homem indolente que apenas suporta parcos esforços, mesmo que outro aguente outros ainda maiores com facilidade.

\section{O burro, o corvo E o lobo (Hsr. 202, CH. 274)}

Um burro, ferido no lombo, pastava num prado. E, como um corvo pousou e picava a ferida, o burro zurrava com dores e empinava-se. Então, dado que o dono do burro, que estava à distância, se ria (disso); um lobo que andava

${ }^{48}$ Esta fábula encontra um paralelo na tradição fabular indiana, mas precisamente na fábula "O burro com pele de tigre (cf. Panchatantra 4. 8) 
por ali reparou e disse para si próprio: "Infelizes de nós que, apenas somos vistos por alguém, nos perseguem e com isto ainda se riem de nós."

A fábula mostra que os homens perversos são identificados até pelo seu aspecto.

\section{O burro, a raposa e o leÂo (Hsr. 203, СH. 270)}

Um burro e uma raposa, acordada uma sociedade entre eles, saíram para a caça. Mas, ao encontrarem por acaso um leão, a raposa, perante o perigo eminente, aproximou-se do leão e prometeu entregar-lhe o burro, se lhe garantisse a segurança. Como ele afirmasse que a libertava, a raposa conduziu o burro e fê-lo cair numa armadilha. Mas o leão, vendo que o burro (já) não era capaz de fugir, apanhou primeiro a raposa e só depois se voltou para o burro.

Da mesma forma, aqueles que maquinam contra os seus sócios, sem terem consciência muitas das vezes também com eles se perdem.

\section{A galinha e a andorinha (HsR. 206, С}

Uma galinha, que encontrou uns ovos de serpente, depois de incubá-los cuidadosamente, abriu as cascas. E uma andorinha que a viu disse: "Palerma! Porque cuidas aquilo que quando crescer começará primeiro por ti a praticar o mal."

Da mesma forma, a perversidade é indomável, ainda que lhe sejam prestados os serviços mais valorosos.

\section{O Passarinheiro E A Cotovia (Hsr. 207, CH. 283)}

Um passarinheiro preparava armadilhas para pássaros. Ora, uma cotovia que o viu perguntou o que fazia. Este disse 
que criava uma cidade e retirou-se por um bocado. A ave, acreditando nas suas palavras, aproximou-se e, sem darse conta, ao debicar o isco, caiu na armadilha. E como o passarinheiro se aproximasse a correr, aquela disse: "Ó tu! Se fazes cidades como esta, não vais arranjar muitos habitantes."

A fábula mostra que casas e cidades ficam ermas, sempre que os governantes são violentos.

\section{O passarinheiro e a Cegonha (Hsr. 208, Сh. 284)}

Um passarinheiro, que tinha estendido umas redes para grous, esperava ao longe pela caça. Entretanto, uma cegonha pousou junto dos grous. $\mathrm{O}$ passarinheiro correu a apanhá-la, juntamente com os outros. Porém, a cegonha pediu que a soltasse, alegando que não era nociva para os homens, ao contrário, era muito útil, porque ao apanhar serpentes e outros répteis, acabava com eles. E o passarinheiro disse: "Ainda que não sejas propriamente má, mereces um castigo por te teres metido entre os malvados."

Em verdade, também nós devemos evitar a relação com os perversos para não parecermos ser cúmplices das maldades deles. ${ }^{49}$

\section{A PRimeira Vez QUe UM CaMelo foI Visto (HsR. 210, Сн. 148)}

Quando pela primeira vez se viu um camelo, os homens tiveram medo e, impressionados com o seu tamanho, fugiram. Todavia, quando com o tempo se aperceberam da sua mansidão, atreveram-se a chegar-se um pouco. E, ao

${ }^{49}$ Poderia evocar-se, com o mesmo sentido, o ditado popular: "Diz-me com quem andas, dir-te-ei quem és.” 
entenderem pouco depois ser um animal manso, tornaramse tão confiantes, que até lhe puseram bridas e o deram às crianças para o montarem.

A fábula mostra que o costume mitiga bastante $o$ medo das coisas.

\section{A SERPENTE E O CARANGuejo (Hsr. 211, Ch. 290)}

Uma serpente e um caranguejo viviam no mesmo sítio. E o caranguejo comportava-se para com a serpente honradamente e com amabilidade, mas esta era sempre traiçoeira e maliciosa. Exortada continuamente pelo caranguejo a ser leal com ele e a imitar a sua disposição, ela não se deixava persuadir. Então, o caranguejo, irritado com isso, esperou que ela dormisse e, agarrando-a pelo pescoço, matou-a. E ao vê-la prostrada, disse: "Ó tu, não é agora que deves ser correta, quando estás morta, mas quando te aconselhava e não ligavas.”

Esta fábula contar-se-ia justamente aos homens que, sendo malvados para os amigos durante a sua vida, deixam as boas acçóes para depois da morte.

\section{A SERPENTE, A doninha E os Ratos (Hsr. 212, CH. 289)}

Uma serpente e uma doninha lutavam numa casa. Ora, os ratos que ali havia, constantemente devorados por uma ou por outra, quando as viram a combater, saíram confiantes. Mas elas, ao verem os ratos, desistiram do combate entre elas e voltaram-se contra eles.

Assim, também nas cidades, os que se envolvem nas lutas de demagogos, sem se aperceberem, transformam-se eles próprios em vítimas dos dois. 
198. A Serpente Que fol Pisada e Zeus (Hsr. 213, С . 291)

Uma serpente que foi pisada por muitos homens, apelava a Zeus. E Zeus disse-lhe: "Pois se tivesses atacado o primeiro que te pisou, não tinham tentado fazer isso."

A fábula mostra que aqueles que enfrentam os primeiros ofensores, fazem-se terríveis para os demais.

\section{O rapaz E O escorpiâo (HsR. 215, СH. 293)}

Um rapaz caçava gafanhotos ${ }^{50}$ junto de um muro. Tinha já apanhado muitos, quando viu um escorpiāo e, como julgava ser um grilo, levantou a mão e estava a ponto de a deixar cair sobre ele. Então, o escorpião aprontou o ferrão e disse: "Oxalá o tivesses feito, para também largares os gafanhotos que apanhaste."

Esta fábula ensina-nos que não se deve proceder de igual forma com todos, com os bons e com os maus.

\section{O Menino ladráo e A mấe (Hsr. 216, СH. 296)}

Um menino, tendo roubado na escola uma tabuinha ${ }^{51}$ de um colega, levou-a à mãe. Esta não só não o repreendeu como ainda o louvou. Na segunda vez, roubou um manto, levou-lho e a mãe louvou-o ainda mais. Com o correr dos

${ }^{50}$ Uma tradução possível, e adequada ao contexto popular grego, seria o termo "saltóes".

51 Corresponderia ao instrumento de rascunho no processo de aprendizagem e treino da escrita. Seria acompanhado por um estilete para

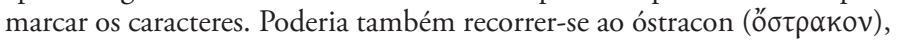
mais acessível e que não seria mais do que um caco de cerâmica. 
anos, tendo-se feito um jovem rapaz, dedicou-se a roubos maiores. Ora, tendo sido apanhado uma vez em flagrante, conduziram-no ao cadafalso com as mãos amarradas atrás das costas. Como a mãe o acompanhasse, enquanto dilacerava o peito, ele falou: "Quero dizer uma coisa ao ouvido da minha mãe." E assim que ela se aproximou dele, apanhou-a por uma orelha e arrancou-a à dentada. Então, como ela o acusasse de impiedade, ele disse: "Pois se me tivesses repreendido na altura em que pela primeira vez trouxe a tabuinha roubada, não tinha chegado até aqui, ao ponto de ser conduzido à morte.”

A fábula mostra que o que não se reprime na origem, cresce até fazer-se maior.

\section{O POMbo SEDENTo (HsR. 217, СH. 301)}

Um pombo, atormentado pela sede, ao ver o desenho de um krater ${ }^{52}$ com água, supôs ser real. Por isso, lançouse com grande estrondo e sem dar conta chocou contra o desenho. Então aconteceu que, ao romperem-se as asas, caiu ao chão e foi capturado por uma pessoa que por ali andava.

Da mesma forma, alguns homens que por causa de fortes paixóes deitam mãos à obra irreflectidamente, lançamse também para a sua própria destruição.

\section{A pomba e a gralha (Hsr. 218, CH. 302)}

Um pombo, criado num pombal, vangloriava-se da sua fecundidade. E uma gralha, ao ouvir as suas palavras,

${ }^{52} \mathrm{~K} \rho \alpha \tau \eta ́ p$, recipiente que tinha como principal função a mistura de água e vinho. [Scheibler, Ingeborg (Krefeld). "Krater." Brill's New Pauly. Brill Online, 2013. Reference. Universitätsbibliothek der Freien (Univ Berlin). 15 March 2013 http://www.paulyonline.brill.nl/entries/brill-snew-pauly/krater-e622100] 
disse: "Minha cara, deixa de te gabar disso, pois quantos mais rebentos tiveres, maior servitude lamentarás."

Da mesma forma, também os serventes mais desgraçados são os que têm mais filhos no tempo de escravidão.

\section{O maCaCo e os pescadores (Hsr. 219, Сh. 304)}

Um macaco, sentado no topo de uma árvore, como viu que uns pescadores atiravam a rede ao rio, observava atentamente o que estavam a fazer. E quando eles recolheram a rede e a deixaram um pouco, o macaco desceu e tentava fazer as mesma coisas, pois dizem ser um animal imitador. Todavia, ao agarrar a rede, ficou preso e disse para si próprio: "Mas eu sofro o que é justo. Pois porque me pus a pescar sem ter aprendido?"

A fábula mostra que a tentativa de fazer o que não é próprio, não só é inconveniente, como também prejudicial.

\section{O Rico e O Curtidor de Peles (Hsr. 220, Сh. 309)}

Um (homem) rico foi viver para junto de um curtidor. $\mathrm{E}$ não podendo suportar o mau cheiro, insistia para que o outro se mudasse. Porém, o curtidor ia-o entretendo, dizendo que se mudaria em breve. Como isto se repetia continuamente, aconteceu que com o decorrer do tempo o rico, habituado ao mau cheiro, deixou de importunar o curtidor.

A fábula mostra que o hábito atenua também as circunstâncias desagradáveis.

\section{O Rico e as Carpideiras (Hsr. 221, Сh. 310)}

Um rico tinha duas filhas e, ao morrer uma delas, contratou umas carpideiras. Contudo, a outra disse à máe: "Mas que desgraçadas somos, pois nós estamos de luto, mas 
não sabemos prantear, enquanto estas que nada têm com o caso, dilaceram-se e choram com tamanho vigor." A mãe respondeu: "Pois não te admires filha, se acaso se lamentam assim, uma vez que o fazem por dinheiro.”

Da mesma forma, algumas pessoas não hesitam em explorar os males alheios por ganância de dinheiro.

\section{O PASTOR E O CÃo (HsR. 222, CH. 312)}

Um pastor, que tinha um cão enorme, costumava atirar-lhe os fetos e as ovelhas mortas. E um dia, enquanto o rebanho entrava, o pastor, vendo que o cão se aproximava das ovelhas a abanar a cauda, disse: "Eh tu, que te saia da cabeça aquilo que estás a matutar.”

A fábula é oportuna para o homem adulador.

\section{O PAStor E O MAR (Hsr. 223, CH. 311)}

Um pastor, que apascentava o seu rebanho junto ao mar, ao vê-lo sereno e quieto, sentiu desejo de navegar. Por esse motivo, vendeu as suas rezes, comprou tâmaras na ágora, embarcou-as num barco e fez-se ao mar. Contudo, ao levantar-se uma violenta tempestade, o barco afundouse e, tendo perdido tudo, rumou a terra. Quando a acalmia voltou, como viu um homem exaltar a tranquilidade do mar, disse: "Eh tu, pois é, quer as tuas tâmaras."

Da mesma forma, muitas vezes as desgraças convertemse em liçóes para os sensatos.

\section{O pastor E as OVElhas (Hsr. 224, СH. 316)}

Um pastor conduzia as ovelhas para um bosque e, ao ver um enorme carvalho carregado de bolotas, estendeu por baixo o manto, trepou à árvore e sacudia a fruta. Mas 
as ovelhas, ao comerem as bolotas, sem perceber, roeram também o manto. Então quando o pastor, ao descer, viu o que sucedera, disse: "Ó malditos animais, vós forneceis a lã para vestir os outros e a mim, que vos alimento, tirais-me o manto."

Desta forma, também muitos homens, por desconhecimento, ao prestar serviço a quem nada interessa, agem de forma negligente contra os seus assuntos.

\section{O PASTOR E AS CRIAS DO LOBO (HsR. 225/CH. 313)}

Um pastor viu umas crias de lobo e criou-as com muito cuidado, acreditando que, chegadas à maturidade, não só guardariam o seu rebanho, mas também rapinariam o dos outros e o trariam para si. Elas, mal cresceram, a primeira vez que aconteceu estarem em segurança dizimaram completamente o seu rebanho. Então o pastor, em lágrimas, disse: "Mas foi justo o que me aconteceu. Pois porque poupei quando eram pequenos, os que devia matar quando são grandes?”.

Da mesma forma, os que salvam a vida aos malvados não percebem que em primeiro lugar os fortalecem contra eles próprios.

\section{O pastor brincalhấo (HsR. 226, CH. 318)}

Um pastor, que conduzia o rebanho para longe da aldeia, pregava a seguinte partida: chamava aos gritos os aldeóes, dizendo que os lobos atacavam as ovelhas. Ora os aldeões assustados, duas e três vezes, acudiam a correr, regressando depois enganados. Finalmente aconteceu que os lobos atacaram de verdade e, enquanto o rebanho era pilhado, o pastor gritava aos aldeóes por ajuda. Porém, como 
os aldeóes suspeitavam que brincava como de costume, não fizeram caso. E assim, aconteceu ficar sem as ovelhas.

A fábula mostra que os mentirosos apenas ganham isto: não terem crédito quando dizem a verdade.

\section{O MEnino QUe Tomava Banho (HsR. 230, СH. 297)}

Certa altura, um menino que tomava banho num rio, estando em perigo de se afogar, ao ver um caminhante, chamou-o para que o socorresse. Ora, como ele admoestasse o menino por ser atrevido, aquele disse-lhe: "Por agora ajudame, mais tarde, já a salvo, reprova-me."

[A fábula conta-se a propósito daqueles que, contra si mesmos, fornecem ocasião para que os critiquem.]

\section{A Ovelha tosquiada (HsR. 232, Сh. 321)}

Uma ovelha, tosquiada de forma desajeitada, disse a quem a tosquiava: "Se queres lâ, corta mais acima; se desejas carne, sacrifica-me de uma vez, e deixa de me torturar aos poucos.

Para os que sem natural talento se dedicam aos ofícios, a fábula é oportuna.

\section{A româ, o damasco e a Silva (HsR. 233, CH. 324)}

Uma romã e um damasco disputavam sobre a sua fertilidade. E como a discussão subisse muito de tom, uma silva, que os ouvia a partir de uma vala próxima, disse: "Mas, ó amigos, de uma vez paremos de discutir."

Da mesma forma, no meio das disputas entre os melhores, também os que nada valem tentam destacar-se. 


\section{A toupeira (Hsr. 234, СH. 326)}

A toupeira - que é um animal cego - disse à sua mãe: "vejo". E ela, pondo-o à prova, deu-lhe um grão de incenso e perguntou-lhe o que era. A toupeira disse que era uma pequena pedra e a mãe disse: "Ó filho, não só estás privado de vista, como também perdeste o olfacto."

Da mesma forma, alguns fanfarróes proclamam tanto trabalhos impossíveis, que acabam desmascarados através das coisas mais triviais.

\section{As vespas, as Perdizes e o lavrador (Hsr. 235, СH. 330)}

Certo dia, umas vespas e umas perdizes, atormentadas pela sede, foram ter com um lavrador e pediram-lhe de beber. Em troca de água, prometeram que as perdizes cavariam as vinhas e fá-las-iam belas e formosas; e que as vespas rondálas-iam e manteriam os ladróes à distância com os seus aguilhóes. Ora, o lavrador disse: "Olha que esta! Tenho uma parelha de bois que fazem tudo sem prometer-lhes nada, portanto, é melhor dar a eles do que a vós."

Para o homem ingrato a fábula é oportuna.

\section{A vespa e A SERPENTE (HsR. 236, СH. 331)}

Uma vespa pousou na cabeça de uma cobra e, golpeando continuamente com o seu aguilhão, atormentava-a. E esta, ao ficar em estado de grande sofrimento e náo conseguindo defender-se do inimigo, pôs a cabeça debaixo da roda de um carro e, dessa forma, morreu juntamente com a vespa.

Para os que se atrevem a morrer juntamente com os inimigos. 


\section{O touro E as Cabras Selvagens (Hsr. 242, CH. 332)}

Um touro, perseguido por um leão, refugiou-se numa caverna onde havia cabras selvagens. Então, atacado e marrado por elas, disse: "Suporto-vos, não porque vos tema, mas sim por ter medo daquele que está à boca da gruta."

Da mesma forma, muita gente, por medo dos que são mais fortes, aguenta ultrajes até do mais fracos.

\section{As CRIAS DE MACACO (HsR. 243, CH. 307)}

Dizem que os macacos trazem ao mundo duas crias e também que, da prole, a uma amam e tratam com cuidados, mas à outra odeiam e negligenciam. Aconteceu, porém, que por providencia divina, a tratada com cuidado morreu e a negligenciada cresceu perfeitamente.

A fábula mostra que a sorte se faz mais forte do que toda a previsão.

\section{O pavão e a gralha (Hsr. 244, CH. 334)}

Quando as aves debatiam acerca do rei, um pavão pretendia ser aclamado rei por causa da sua beleza. E estavam as aves dispostas a isso, quando uma gralha disse: "Mas e se quando fores rei a águia nos perseguir, como nos vais proteger?"

A fábula mostra que os líderes não devem estar abonados com beleza, mas sim com poder.

\section{O CAMelo, O Elefante E O MACACo (Hsr. 246, С . 145)}

Os animais irracionais queriam eleger um rei. $\mathrm{O}$ camelo e o elefante, que se apresentaram como candidatos, disputavam ser preferíveis a todos os outros, pelos seus tamanho e força. Todavia, um macaco disse serem ambos 
inadequados, o camelo porque não tem valor para enfrentar os malfeitores e o elefante porque é de temer que, sendo ele rei, os ataque um leitáo, animal de que o elefante tem medo.

A fábula mostra que. muitas vezes, mesmo as coisas mais importantes são impedidas pelas razóes mais insignificantes.

\section{Zeus E A SERPENTE (Hsr. 240, CH. 122)}

Quando Zeus se casou, todos os animais trouxeram presentes. Ora, a serpente ao trepar, subiu carregando uma rosa na boca. Então, ao vê-la Zeus, disse: "De todos os demais aceito das patas os presentes, mas da tua boca nada aceito."

A fábula mostra que são de temer as graças de todos os malvados.

\section{A porca e a CADELa I (Hsr. 250,Сh. 342)}

Um porca e uma cadela discutiam entre si. A porca jurava por Afrodite que, caso não parasse, despedaçá-la-ia com os seus dentes. Porém a cadela disse que esse juramento era absurdo, pois Afrodite detestava a porca de tal forma que, se alguém comesse a sua carne, náo o deixava entrar no seu templo. ${ }^{53}$ Ora, a porca disse em resposta: "Ó minha cara, não faz isso por me odiar, mas de modo a prevenir que eu seja sacrificada."

${ }^{53}$ A tradição que considera a carne de suíno impura e, consequentemente, poluente do rito religioso, encontra paralelo em várias culturas semíticas e indo-europeias, ainda que no contexto indo-europeu o conceito náo transcenda o âmbito religioso - algo que sucede com as antigas culturas semíticas. Esta particularidade dever-se-á à complexa relação em origem entre as culturas religiosas da regiáo do antigo mediterrâneo e mesopotâmia; note-se como exemplo o paralelo entre as deusas Istar e Afrodite (Budin 2004). 
Da mesma forma, os oradores sagazes muitas vezes convertem em louvores os argumentos acusatórios dos adversários.

\section{A PORCA E A CADELA II (SOBRE A FECUNDIDADE)}

\section{(HsR. 251, Сн. 342)}

Uma porca e uma cadela discutiam acerca da sua fecundidade. E como a cadela dissesse ser aquela que de entre os quadrúpedes paria em menos tempo, a porca disse: "Mas quando dizes isso, apercebe-te de que os pares cegos.”

A Fábula mostra que as acçóes não se avaliam pela celeridade, mas sim pela perfeição com que são praticadas.

\section{O javali e a Raposa (HsR. 252, CH. 327)}

Um javali estava parado junto a uma árvore e afiava os dentes. E, quando uma raposa lhe perguntou porque razão, sem ameaça de caçador ou de qualquer perigo, aguçava os dentes, ele disse: "Não é por estupidez que o faço. Pois, se algum perigo me sobrevier, não é então que me vou preocupar em os afiar, mas necessitarei deles já preparados."

A fábula ensina que devem realizar-se os preparativos antes dos perigos.

\section{O AVarento (HsR. 253, СH. 344)}

Um certo avarento, que convertera em dinheiro toda a sua propriedade e o gastara num lingote de ouro, escondeu-o numa parede e frequentemente ia inspeccioná-lo. Um dos que por ali trabalhava, ao reparar nas suas idas e vindas, adivinhou o motivo, foi até ele e levou-o. Quando o avaro regressou e viu o lugar vazio, pôs-se a chorar e a arrancar os cabelos. Então, alguém que o viu a lamentar-se tanto e 
o interpelou sobre a razão, disse-lhe: "Eh tu, não te aflijas camarada, apanha uma pedra, coloca-a no mesmo sitio e imagina que está ali um tesouro, pois quando o tinhas, não te servias dele."

A fábula mostra que a posse nada vale, se o uso não a acompanha.

\section{A tartaruga e a lebre (Hsr. 254, CH 352)}

A tartaruga e a lebre discutiam entre si qual delas era a mais veloz. Então, tendo combinado um dia e um lugar, separaram-se. No entanto, a lebre, fiada na sua natural rapidez, não se fez logo ao caminho, optando antes por deitarse junto ao carreiro e tirar uma soneca. Porém, a tartaruga, consciente da sua própria lentidão, não parou de correr e, desse modo, ao ultrapassar a lebre que dormia, conseguiu o prémio da vitória.

A fábula mostra que muitas vezes o esforço leva a melhor sobre a natureza descuidada.

\section{A ANdorinha e A SERPENTE (HsR. 255, CH. 347)}

Uma andorinha que nidificou num tribunal, voou dali. E uma serpente que se aproximou devorou-lhe a ninhada. Regressada a andorinha, encontrou o ninho vazio e, em grande sofrimento, lamentava-se. Então outra andorinha que a queria confortar disse-lhe que, na verdade, não só a ela ocorrera perder os filhos. E aquela em resposta disse: "Mas eu não choro por causa dos meus filhos, antes por ter sido vítima num local onde os que são enganados encontram ajuda."

A fábula mostra que as desgraças se tornam mais difíceis de suportar, se infligidas por quem menos se espera. 


\section{Os gansos e as garças (HsR. 256, Сн. 353)}

Os gansos e as garças alimentavam-se no mesmo prado. Quando apareceram uns caçadores, as garças, mais ligeiras, voaram; mas os gansos, retardados por terem um corpo mais pesado, foram capturados.

Da mesma forma, também os homens pobres, quando se gera uma guerra na cidade, mais leves em carga, facilmente passam de uma cidade para a outra. Contudo, os ricos, retidos pelo excesso de bens, acabam por ser subjugados.

\section{A andorinha e a gralha (Hsr. 258, С}

A andorinha e a gralha discutiam acerca da sua beleza. E a gralha, em resposta à andorinha, disse: "Mas a tua beleza floresce apenas na primavera, enquanto o meu corpo resiste também ao inverno."

A fábula mostra que o vigor do corpo é mais importante que a beleza.

\section{A tartaruga e a águia (Hsr. 259, С . 351)}

Uma tartaruga, ao ver o voo de uma águia, teve também vontade de voar. Então, foi visitar a águia e pediulhe para lhe ensinar pelo custo que lhe aprouvesse. E embora a águia dissesse ser impossível, insistia e incitava-a, pelo que aquela agarrou-a e levou-a pelos ares, até a largar sobre uma rocha, onde tendo caído se despedaçou e morreu.

A fábula mostra que muitos homens, em busca pela glória, prejudicam-se a si mesmos. 


\section{A pulga e o atleta (Hsr. 260, Сн. 256)}

Numa certa ocasião, num salto, uma pulga pousou no pé de um atleta que fazia exercício e, ao pular, picou-o. E o atleta, muito irritado, estava a ponto de esmagar a pulga com as unhas. Porém, com um impulso espontâneo, ela deu um salto, escapou e salvou-se da morte. Ora, ao lamentarse, o atleta disse: "Ó Héracles, quando me assistes deste modo contra uma pulga, como me apoiarás contra os meus rivais?"

Portanto, a fábula ensina-nos que não devemos evocar logo os deuses por assuntos de pouca importância e inofensivos, mas antes durante as maiores necessidades.

\section{As raposas no rio Meandro $^{54}$ (Hsr. 231, Ch. 29)}

Um dia as raposas reuniram-se na margem do Meandro por desejarem nele beber. Contudo, por levar água impetuosa, incentivavam-se umas às outras sem se atreverem a entrar. Uma delas avançou para menosprezar as restantes: ria da cobardia delas e, julgando-se a mais valente, confiante, lançou-se à água. E arrastando-a a corrente para o meio, as outras, que permaneciam na margem do rio, disseram-lhe: "Não nos deixes, mas volta e mostra-nos um acesso por onde sem perigo possamos beber." Contudo, a outra, arrastada, respondeu: "Uma mensagem tenho para Mileto e quero levála até lá. No meu regresso mostro-vos."

Contra aqueles que por fanfarronice se expóem ao perigo.

${ }^{54}$ Rio da Ásia Menor com um curso muito sinuoso, que corre entre a Lídia e a Cária e desagua em Mileto. 


\section{O CISNE E O AMO (HsR. 247, СH. 174)}

Diz-se que os cisnes cantam perante a morte ${ }^{55}$. Ora, um homem, que encontrou um cisne à venda, como tinha ouvido dizer que o cisne era um animal muito melodioso, comprou-o.

Numa certa ocasião em que tinha convidados, aproximou-se do cisne e pediu-lhe que cantasse durante o banquete. Nessa altura, o animal ficou em silêncio, porém, mais tarde, ao sentir que ia morrer, entoou o seu próprio Treno ${ }^{56}$; e ao ouvi-lo, o amo disse: "Pois se tu apenas cantas quando estás a morrer, eu fui parvo ao pedir-te para cantares em vez de te sacrificar."

Da mesma forma, alguns homens, aquilo que não querem conceder voluntariamente, fazem-no contra a vontade.

\section{O LObo e o PASTOR (HsR. 165, CH. 229)}

Um lobo seguia um rebanho de ovelhas e não lhes fazia mal. Ora, no inicio o pastor vigiava o lobo como um inimigo e, alarmado, observava-o com atenção. Mas depois, como ele acompanhava continuamente sem fazer mal e de modo algum tentava roubar, julgou então ser mais um protector do que um ardiloso.

Quando teve necessidade de descer até à cidade, deixou o rebanho com o lobo e partiu. Então este aproveitou a oportunidade que tinha e dizimou a maior parte das rezes. E o pastor, ao regressar e ver o rebanho dizimado, disse: "Aconteceu-me o que é justo; ora porque confiei um rebanho a um lobo?"

${ }^{55}$ Esta é uma tradição comentada no Fédon de Platão (Cf. 84e-85b).

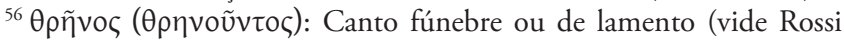
1999). 
Da mesma forma, os homens que entregam os seus bens aos ávidos de dinheiro e ambiciosos naturalmente perdem-nos.

\section{A formiga e o POMbo (Hsr. 176, CH. 242)}

Um formiga com sede, que desceu até uma fonte com intenção de beber, estava a ponto de se afogar. Uma pomba, pousada numa árvore ali próxima, cortou uma folha e atiroulha. E a formiga subiu para cima dela e salvou-se. Mas um passarinheiro, que por ali andava com canas preparadas ${ }^{57}$, quis apanhar o pombo. Porém, a formiga surgiu e mordeulhe o pé. E o passarinheiro, ao sacudir-se, abanou as canas e o pombo fugiu e pôs-se a salvo.

Também os mais insignificantes são capazes de proporcionar recompensas aos seus bem feitores.

\section{Os viajantes E O CORVo (HsR. 227, СH. 255)}

A uns que viajavam em negócios, apareceu-lhes um corvo zarolho. Estes voltaram-se e como um deles aconselhasse o regresso - pois isso era o que a ave pressagiava -, outro disse em resposta: "Como pode este adivinhar-nos o futuro, quando nem sequer previu a própria mutilação, a fim de a evitar?"

Da mesma forma, os que estão mal informados nos seus próprios assuntos, também estão desacreditados para dar conselhos ao próximo.

${ }^{57} \mathrm{O}$ termo em causa, Kó $\lambda \alpha \mu o \varsigma$, refere-se provavelmente a uma armadilha feita com canas. Vide Hünemörder, Christian (Hamburg). "Reed." Brill's New Pauly. Brill Online, 2013. Reference. Universitätsbibliothek der Freien (Univ Berlin). 17 March 2013 <http://www.paulyonline.brill.nl/ entries/brill-s-new-pauly/reed-e1103740>. 


\section{O burro comprado Na ÁGora (HsR. 200, С}

Um homem, que ia comprar um burro, levou-o para experiência e, deixando-o entre os seus próprios burros, pô-lo no curral. Então o burro distanciou-se dos outros e foi para junto do mais mandriáo e glutão. E, como ele não trabalhava, o homem laçou-o, reconduziu-o ao dono e devolveu-o. Ora, quando aquele lhe perguntou se tinha feito um teste conveniente, ele em resposta disse: "Mas não preciso de mais experiências, pois percebo que é igual ao colega que escolheu entre os outros."

É suposto cada um ser da mesma estirpe dos companheiros a quem se associa.

\section{O passarinheiro e os pombos (HsR. 209, Сh. 282)}

Um passarinheiro estendeu as suas redes e atoulhes uns pombos domésticos. Entretanto, afastou-se e aguardava atentamente o resultado à distância. Quando se aproximaram uns pombos selvagens e se enredaram nas redes, o passarinheiro correu a tentar apanhá-los. Como estes culpassem os domésticos por, sendo da mesma espécie, não os terem alertado para a armadilha, eles disseram em resposta: "Pois para nós é melhor cuidar dos nossos amos que agradar aos nossos parentes."

Da mesma forma, também entre os servos não são censuráveis os que, por amor aos seus senhores, faltam com afecto aos seus parentes. 


\section{O Juramento ${ }^{58}$ (Hsr. 214, Сh. 298)}

Um certo homem, que tinha recebido de um amigo um depósito em dinheiro, pensou ficar com ele. E como aquele o incentivasse a prestar juramento, foi para o campo preocupado. Porém, ao chegar às portas da cidade, viu um coxo e perguntou-lhe quem era e onde ia. Este disse que era o Juramento e que ia ter com os ímpios; a seguir perguntava de quanto em quanto tempo visitava as cidades. Ele respondeu: "Cada quarenta anos, às vezes trinta." Portanto, no dia seguinte jurou sem hesitar que não tinha recebido o depósito. Mas o Juramento atirou-se a ele e levou-o até um precipício. O homem reprovava-o, alegando que tinha dito não voltar em trinta anos e não lhe ter dado um único dia como garantia. Entâo, o Juramento disse em resposta: "Pois inteira-te bem, sempre que alguém me maltrata demasiado, costumo visitá-lo no mesmo dia."

Por tal, o castigo do deus aos malvados não é definido previamente.

\section{Prometeu e os homens (Hsr. 228, Сh. 322)}

Prometeu, mandatado por Zeus, moldou os homens e os animais. Como Zeus viu que os animais eram muito mais numerosos, ordenou-lhe que, destruindo alguns, os transformasse em homens. Depois de fazer o que lhe fora ordenado, aconteceu que os que não haviam sido feitos homens desde o início, tinham forma de homens, mas alma de animal.

A fábula é um argumento a propósito dos homens brutos e irascíveis.

\footnotetext{
${ }^{58}$ Divindade que personifica 'o juramento'.
} 


\section{A cigarra e a raposa (Hsr. 245, Сh. 335)}

Uma cigarra cantava no alto de uma árvore. E uma raposa, que a queria comer, congeminou algo deste género: parou de frente e admirava a sua bela voz, incitando-a a descer e dizendo que desejava contemplar um animal que tem semelhante canto.

A cigarra, adivinhando o embuste, arrancou uma folha e atirou-a. E, ao ver correr a raposa como para a cigarra, esta disse: "Pois equivocas-te, minha cara, se julgas que vou descer. Ora eu tenho estado de olho nas outras raposas, desde que vi nos excrementos de uma delas as asas de cigarra."

Aos homens sensatos as desgraças dos vizinhos fazem-nos prudentes.

\section{A hiena e a Raposa (Hsr. 241, Сh. 341)}

Dizem que as hienas, mudando cada ano a sua natureza, se tornam umas vezes machos outras vezes fêmeas. Ora a dada altura uma hiena viu uma raposa e censurou-a, por não se aproximar e não querer tornar-se sua amiga. Aquela em resposta disse: "Mas não me culpes a mim, antes a tua natureza, porque náo percebo se te trate como amiga ou como amigo.

Contra o homem dúbio.

\section{As hienas (Hsr. 240, СH. 340)}

Dizem que as hienas mudam a cada ano a sua natureza e que umas vezes se fazem machos e outra fêmeas. Ora, numa certa ocasiáo, uma hiena macho montou, contra a natureza, uma fêmea. E aquela disse: "Eh tu, entâo termina isso, pois não tarda sofrerás o mesmo." 
Contra os arcontes ${ }^{59}$ que responsabilizam os que estão sob a sua autoridade e, na sua vez, são obrigados por aqueles a prestar contas do passado.

\section{O papagaio e a doninha (Hsr. 261, CH. 355)}

Um homem, que comprara um papagaio, soltou-o em casa. O papagaio, que estava domesticado, esvoaçou e pousou por ali, e daquele lugar chalreava alegremente. Uma doninha, ao vê-lo, perguntou-lhe quem era e de onde vinha. O papagaio respondeu: "O patrão comprou-me há pouco." E a outra disse: "Muito bem, és o mais ousado dos animais. Como te atreves, sendo um recém chegado, a chalrear de tal modo? Pois a mim, que nasci nesta casa, os amos não me consentem levantar a voz e, se acaso o faço, chateiam-se e batem-me." ${ }^{\circ 0}$ De contrário, tu atreves-te a dizer o que te apetece sem medo." E o papagaio respondeu dizendo: "Senhora da casa, póe-te a milhas daqui, pois os amos não se aborrecem com a minha voz da mesma maneira que com a tua."

Para o homem malicioso que por inveja atira acusaçóes contra os vizinhos.

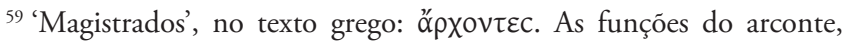
mediante os diferentes períodos da pólis grega, não se restringiam apenas ao julgamento legal e administração da lei, pelo que optámos por manter o termo original de forma a preservar a abrangência do poder e competências associados a esta figura. Vide "Archontes." Brill's New Pauly. Brill Online, 2013. Reference. Universitätsbibliothek der Freien (Univ Berlin). 17 March 2013 <http://www.paulyonline.brill.nl/entries/brill-s-new-pauly/ archontese133000>

${ }^{60}$ Note-se que na Grécia antiga a doninha era um animal comum no ambiente doméstico grego. Vide Hünemörder, Christian (Hamburg). "Weasel." Brill's New Pauly. Brill Online, 2013. Reference. 18 March $2013<$ http://www.paulyonline.brill.nl/entries/brill-s-new-pauly/ weasel-e12210960> 


\section{O MEDricas E OS CORVos (HsR. 290, СH. 47)}

Um homem covarde partiu para a guerra, mas com o grasnar de uns corvos largou as armas e deixou-se quieto. Depois, apanhou-as novamente e prosseguiu o caminho. E quando grasnaram outra vez, parou e disse-lhes por fim: "Pois grasnai quanto conseguirdes, mas não me provareis."

A fábula é acerca dos muito cobardes.

\section{A mulher e o marido bêbado (Hsr. 278, С . 88)}

Um certa mulher tinha um marido borracho e, como queria tirar-lhe o vício, tramou o seguinte: esperou até que adormecesse pela bebedeira e, sem sentidos, como um morto, carregou-o aos ombros, levou-o para o cemitério, largou-o no chão e foi-se embora. Quando percebeu que ele tinha voltado a si, aproximou-se da porta do cemitério e pôsse a bater-lhe. E, ao dizer aquele: "Quem bate à porta?". A mulher respondeu: "Sou eu quem traz comida aos mortos." E aquele: "Mas náo me tragas de comer, antes de beber, minha cara! Pois deixas-me triste ao lembrar a comida e não a bebida." E a mulher dizia, enquanto se autoflagelava: "Ai de mim, desgraçada! Pois não me foi de todo útil o que planejei, dado que tu, homem, não só não te corrigiste, como ainda ficaste pior e o teu vício converteu-se num hábito."

A fábula mostra que não se deve insistir nas más acçóes, pois chega o momento em que, embora sem querer, se impóem ao homem como hábito. 


\section{Diógenes EM VIAJEM (HsR. 65, CH. 98) ${ }^{61}$}

O cínico Diógenes ${ }^{62}$ viajava quando chegou a um rio muito caudaloso e parou, por não conseguir passá-lo. Um certo homem, que se dedicava a atravessá-lo, ao vê-lo parado, aproximou-se e atravessou-o. Diógenes, agradecido pela sua gentileza, queixou-se da sua pobreza, que o impedia de retribuir ao bem feitor. Porém, enquanto pensava nisto, viu outro caminhante que também não podia atravessar. Então, o outro correu para ele e atravessou-o. Ora, Diógenes aproximou-se e disse-lhe: "Pois já não te sou grato pela ajuda, uma vez que percebo que não o fazes por qualquer discernimento, mas por mania.”

A fábula mostra que os que beneficiam os indignos juntamente com os dignos, não só não obtêm reconhecimento, como ainda são acusados de insensatos.

\section{Diógenes e o CAREca (HsR. 65a, CH. 97)}

Diógenes, o filósofo cínico, insultado por um homem calvo, disse: "Na verdade, não recorrerei ao insulto, ao contrário, ao elogio dos teus cabelos, que abandonaram uma cabeça tão malvada.”

${ }^{61}$ Esta fábula serve de anedota ao movimento filosófico cínico e às suas ideias e práticas, conhecidos por moldar os factos, de modo a converter a realidade em algo que fosse oportuno para uma argumentaçáo bem sucedida. Vide Döring, Klaus (Bamberg) RWG. "Kynismus (RWG).” Der Neue Pauly. Herausgegeben von: Hubert Cancik und, Helmuth Schneider (Antike), , Manfred Landfester (Rezeptions- und Wissenschaftsgeschichte). Brill Online, 2013. Reference. 18 March 2013 http://www.paulyonline. brill.nl/entries/der-neue-pauly/kynismus-rwg-e1411040.

${ }^{62}$ Diógenes de Sinope, filósofo cínico.”Diogenes.” Brill's New Pauly. Brill Online, 2013. Reference. 18 March 2013 <http://www.paulyonline. brill.nl/entries/brill-s-new-pauly/diogenes-e318510> 


\section{O CaMelo dançarino (Hsr. 142, CH. 147)}

Um camelo, cujo dono o obrigava a dançar, disse: "Não só sou desajeitado a dançar, como ainda a caminhar." 63

A fábula conta-se acerca de toda a obra carente de graça.

\section{A nogueira (Hsr. 141, Сн. 152)}

Uma nogueira, que estava junto a um trilho e levava pedradas dos transeuntes, lamentava-se, dizendo para consigo: "Pobre de mim, que todos os anos atraio para mim própria insultos e dores."

A fábula é para aqueles que sofrem por causa das suas próprias virtudes.

\section{A cotovia (HsR. 271, Сн. 169)}

Uma cotovia, presa numa armadilha, lamentando-se, dizia: "Ai de mim desgraçada e infeliz ave. Não roubei ouro a ninguém, nem prata, nem outra coisa de valor; e um simples grão de trigo atraiu-me à morte.”

A fábula é para aqueles que, por um desejo mesquinho, se expóem a um grande perigo.

\section{O cão, o galo e a raposa (Hsr. 268, С . 180)}

Um cão e um galo, que haviam feito amizade um com o outro, caminhavam juntos. Caída a noite, chegados a um

${ }^{63}$ Esta fábula assume um carácter proverbial. Fora do contexto literário, é possível que fosse transmitida como um ditado popular. Note-se que no que refere à fábula antiga a distinçáo entre a narrativa didáctica e o provérbio é ténue, quando analisada à luz da hermenêutica contemporânea. 
lugar arborizado, o galo subiu a uma árvore e sentou-se nuns ramos; e o cão, por seu lado, adormeceu em baixo, numa fenda da árvore. Transcorrida a noite e, surgido o brilho da manhá, o galo, como era costume, cantou bem alto. Ora uma raposa ouviu-o e quis devorá-lo. Aproximou-se e parou debaixo da árvore e gritou-lhe: "És boa ave e também útil para os homens; desce pois para entoarmos as cantigas nocturnas e nos alegrarmos ambos." Mas o galo, percebendo, disse-lhe: "Vai, amiga, debaixo da fenda da raiz da árvore e chama a sentinela para percutir o tronco." Mas quando a raposa o foi chamar, logo o cão saltou de pronto e apanhou a raposa, desfazendo-a em pedaços.

A fábula mostra que de modo equivalente também os homens sensatos, quando lhes surge uma desgraça, facilmente se preparam para ela.

\section{O CÁo E O CARAcol (HsR. 265, CH. 181)}

Um cão, que tinha o costume de engolir ovos, ao ver um caracol abriu a boca e, de um trago, engoliu-o, julgando ser um ovo. Então, tendo as entranhas pesadas e sentindose dolorido, disse: "Mas é bem feito, pois convenci-me que todas as coisas redondas são ovos."

A fábula ensina-nos que aqueles que se lançam irreflectidamente num assunto, sem darem por isso, metemse em situaçóes complicadas.

\section{O CÁo E O CARNiceiro (HsR. 134, CH. 183)}

Um cão enfiou-se num açougue e, como o carniceiro estava distraído, roubou um coração e fugiu. Então o carniceiro, ao virar-se e vendo-o em fuga, disse: "Eh tu, sabe que, onde quer que estejas, ficarei de olho em ti, pois tu não 
me tiraste um coração, ao contrário, deste-me ânimo.”64

A fábula mostra que, muitas vezes, os infortúnios são liçóes para os homens.

\section{O MOSQUito E O LEÃo (HsR. 267, CH. 188)}

Um mosquito aproximou-se de um leão e disse: "Não tenho medo de ti, nem és mais forte do que eu. Caso contrário qual é a tua força? Arranhares com as unhas e morderes com os dentes? Isso também faz a mulher que luta com o marido. Eu, pelo contrário, sou muito mais poderoso do que tu. E, se queres, vamos então a um combate.

E, ao soar da trombeta, o mosquito acometeu, picando-lhe a parte sem pelo da cara, à volta do nariz. Então o leão feriu-se com as suas próprias garras, até se render. E o mosquito, vencido o leão, tocou a trombeta, entoou um epinício e levantou voo. Enredou-se então numa teia de aranha e, ao ser devorado, lamentava-se por lutar com os maiores animais e ser aniquilado por um bicho mesquinho: a aranha.

\section{As lebres e as raposas (HsR. 169, СH. 190)}

Umas lebres, a dada altura em guerra com umas águias, chamaram para uma aliança as raposas. Então, estas retorquiram: "Nós ajudávamos, se não soubéssemos quem vós sois e com quem combateis."

A fábula mostra que quem gosta de disputas com os mais fortes arrisca-se também ao fracasso.

${ }^{64} \mathrm{O}$ texto apoia-se no jogo semântico com o vocábulo $k \alpha \rho \delta i ́ \alpha v$, dado que além de identificar o coração, enquanto órgão, este termo também pode significar coragem ou ânimo em sentido figurado. 


\section{A leoa e a Raposa (Hsr. 167, CH. 194)}

Uma leoa, censurada por uma raposa por nunca gerar mais do que uma cria, respondeu: "Mas um leão!"

A fábula mostra que o belo não está no número, mas na virtude.

\section{O LEÁO DOENTE, O LOBO E A RAPOSA \\ (HsR. 269, Сн. 205)}

Um leão, envelhecido, jazia doente numa caverna. Vieram visitá-lo o rei e (todos) os outros animais, excepto a raposa. Entâo o lobo, aproveitando a oportunidade, maldizia a raposa diante do leão que, na verdade, não o considera o mais poderoso de todos e que por essa razão não veio em visita. Mas, entretanto, a raposa também apareceu e ouviu as últimas palavras do lobo.

Ora o leão rugiu para a raposa, mas ela, pedindo um momento para a sua defesa, disse: "Mas quem, dos aqui reunidos foi tấo útil quanto eu, que deambulei por todo lado para procurar e aprender tratamento para ti junto dos médicos?"

E quando o leão ordenou que de imediato falasse da terapia, ela respondeu: "Se esfolares um lobo vivo, póe-te em cima da pele dele ainda quente." O lobo imediatamente caiu morto e a raposa, rindo-se, comentou: "Assim, não é necessário instigar ao Soberano a má vontade, mas a benevolência."

A fábula mostra que quem trama contra outrem, atrai sobre si a trama. 


\section{O leáo, Prometeu e o elefante (Hsr. 292, Ch. 210)}

Um leão censurava com frequência a Prometeu, por o ter moldado grande e belo, armado a mandíbula com dentes e fortalecido as patas com garras tornando-o mais forte do que as outras feras: "Mas tal como sou," ia dizendo, "tenho medo do galo." Então Prometeu respondeu: "Mas porque razão vã me acusas? Pois tens tudo aquilo que me era possível modelar e o teu ânimo acobarda-se por isso apenas?" Lamentava-se o leão e, acusando-se a si mesmo de cobardia, desejava morrer.

E com este estado de espírito, aconteceu encontrar um elefante, saudou-o e parou para conversar. E, ao ver que continuamente movia as orelhas, disse: "O que tens?! Nunca param um momento as tuas orelhas?" E o elefante, com o acaso de à volta de si voar um mosquito, disse: "Vês este pequeno a zumbir? Se me entra no canal do ouvido, estou perdido." E o leão disse: "Porque tenho na verdade ainda de morrer, se sou mais afortunado que o elefante, quanto o galo é mais forte que o mosquito?"

Veja-se quanta força tem o mosquito, que até amedronta um elefante.

\section{O lobo gabarola e o leÃo (HsR. 210, CH. 219)}

Um lobo, que vagueava por lugares desertos, declinava já o sol para o ocaso, viu a sua sombra alongada e disse: "tenho eu medo do leão, quando sou tão grande? Com o tamanho de um pletro $^{65}$, das feras, todas juntas, não serei capaz de facilmente me tornar soberano?"

$\mathrm{E}$, ao lobo fanfarrão um forte leão o arrebatou para o devorar. Então ele, arrependido, gritou: "A presunção é para nós causa de desgraças.”

${ }^{65}$ Unidade de medida correspondente a 29,6 metro (Bailly, 1950). 


\section{O LOBO E O CORDeIro II (Hsr. 161, Сн. 222)}

Um lobo perseguia um cordeiro. Mas este refugiou-se num templo. Então, como o lobo o chamasse e dissesse que o sacerdote o iria sacrificar ao deus se o apanhasse, o cordeiro respondeu: "Mas é preferível para mim tornar-me oferenda ao deus, a ser morto por ti".

A fábula mostra que, para os que têm de morrer, é melhor uma morte com honra.

\section{As árVores e a Oliveira (Hsr. 293, СH. 252)}

Numa certa ocasião as árvores, obrigando-se a eleger um rei para elas, disseram à oliveira: "Reina sobre nós!" E a oliveira disse-lhes: "Vou renunciar ao meu azeite, que é táo estimado pela divindade e pelos homens, para reinar sobre vós?"

Então, as árvores disseram à figueira: "Vem aqui reinar sobre nós!" E disse-lhes a figueira: "Vou aí reinar sobre as árvores, abandonando a minha doçura e o meu excelente fruto?"

Então, as árvores disseram ao espinho: "Vem aqui reinar sobre nós!" E o espinho respondeu às árvores: "Se de facto me elegeis vosso rei, vamos, ponham-se sob a minha protecção; se não, que saia fogo do espinho e devore os cedros do Líbano." ${ }^{\prime 6}$

${ }^{66}$ Esta fábula tem uma versão paralela no antigo testamento (Juizes 9.8 ss). De notar que são parcas as situaçóes em que surgem na fábula esópica plantas falantes. Porém, parece ter existido o conhecimento de uma tradição fabular oriental onde o tema era recorrente. Calímaco

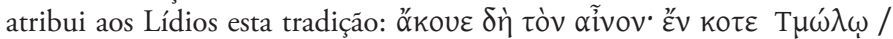

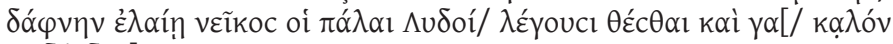

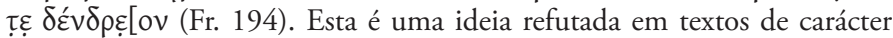
sapiencial orientais, como é o caso do Conto de Ahiqar, cuja antiguidade remonta, pelo menos aos inícios do V a.C. (cf. Grottanelli 1987). 


\section{O burro E A MUla II (Hsr. 204, Сн. 272)}

Um burro e uma mula caminhavam juntos. Nisto o burro, vendo que a carga de ambos era igual, indignou-se e queixava-se de a mula, considerada merecedora do dobro da ração, não levar uma carga maior. Porém, quando tinham avançado um pouco de caminho, o burriqueiro, vendo que o burro não podia aguentar, tirou-lhe parte da carga e colocou-a sobre a mula. De seguida, tinham progredido mais, mas vendo que o burro se cansava com maior intensidade, tirou-lhe novamente parte da carga; até finalmente lhe tirar o resto e a pôr na mula. Então, esta olhou para o burro e disse: "Eh tu, acaso não te parece que, com razão, mereço o dobro da comida?"

$\mathrm{Na}$ verdade, também nós devemos ajuizar a disposição de cada um, náo pela forma como começa, mas como termina.

\section{O burro e o cáo que viajavam Juntos}

(Hsr. 295, Сн. 276)

Um burro e um cão, que caminhavam juntos, encontraram uma carta lacrada no cháo. $\mathrm{O}$ burro apanhou-a, rompeu o selo, abriu-a e leu-a de modo a que o cáo ouvisse. A carta falava acerca de pasto, isto é, forragem, cevada e palha. E o cáo, contrariado pela leitura do burro, disse: "Lê um pouco mais abaixo, amigo, para encontrares algo relativo a carne e ossos: "O burro leu a carta toda e não encontrou nada do que o cão queria. Pelo que o cão replicou: "Larga-a no chão, companheiro, pois carece de interesse."

\section{O passarinheiro e a Perdiz (Hsr. 205, С . 285)}

Um passarinheiro, a quem já tarde aparecera um hóspede, não tendo o que oferecer-lhe, deitou mão a uma perdiz doméstica e estava para a sacrificar. Esta acusou-o de 
ingrato, pois mesmo tendo-lhe sido muito útil ao atrair e atraiçoar os seus congéneres, ele estava disposto a matá-la. Ao que o passarinheiro disse: "Pois é por essa razão que te vou sacrificar, porque nem sequer proteges os da tua espécie."

A fábula mostra que os que atraiçoam os seus, não só são odiados pelas vítimas, como também por aqueles que beneficiam da traição.

\section{As duas Algibeiras (Hsr. 229, Сн. 303)}

Há muito tempo atrás, Prometeu, criador dos homens, pendurou neles duas algibeiras, uma com os males alheios e outra com os próprios; a dos alheios pô-la à frente $\mathrm{e}$ a outra colocou-a atrás. Desde então, sucedeu que os homens vêem logo os defeitos dos outros, mas não reparam nas suas próprias imperfeições.

Esta fábula podia adequar-se ao homem intriguista que, ignorante nos seus próprios assuntos, ocupa-se dos que não lhe dizem respeito.

\section{O PASTOR E O LOBO CRIADO COM OS CÁES (HsR. 276, СH. 315)}

Um pastor, ao encontrar um lobo recém-nascido, recolheu-o e criou-o juntamente com os cães. Quando cresceu, sempre que um lobo arrebatava uma ovelha, ele próprio perseguia-o juntamente com os cães. Nos momentos em que os cães náo eram capazes de alcançar o lobo - e por tal razão regressavam - o outro seguia-o até o ter alcançado e desse modo, enquanto lobo, tomava parte da caça; mais tarde, regressava. Mas se nenhum lobo de fora roubasse o rebanho, ele próprio, em segredo, sacrificava uma vítima e 
banqueteava-se com os cães, até que o pastor, suspeitou e, percebendo o que se passava, o amarrou a uma árvore e o matou.

A fábula mostra que a natureza perversa não alimenta um bom carácter.

\section{A larva e o dragão ${ }^{67}$ (Hsr. 237, Сh. 33)}

Havia uma figueira no caminho. E uma larva, ao ver um dragão a dormir, sentiu inveja do tamanho dele. Então, querendo igualar-se-lhe, deitou-se perto e tentava esticar-se, até que, sem notar, rompeu por esforço em demasia.

Isto sofrem os que rivalizam com os mais fortes, pois rebentam antes de os conseguirem alcançar.

\section{O JaVali, O Cavalo E O CAÇAdor (HsR. 238, СH. 328)}

Um javali e um cavalo pastavam no mesmo lugar. $\mathrm{E}$ como o javali estragasse a erva e enturvasse a água, o cavalo, querendo vingar-se dele, recorreu à ajuda de um caçador. Porém, este disse que não podia ajudá-lo, a não ser que suportasse o freio e o deixasse montar. O cavalo anuiu a tudo. Então o caçador, montado nele, matou o javali. Porém, tendo levado o cavalo, prendeu-o à manjedoura.

Da mesma forma, muitos, desejando livrar-se dos inimigos, submetem-se a outros por causa de uma ira irracional.

${ }^{67}$ Notar que o termo $\delta \rho \alpha ́ k \omega v$ poderia indicar simplesmente uma grande cobra, da subespécie das constritoras. Contudo, optámos por uma tradução o literal do termo, notando que não está em causa a fera da mitologia moderna. 


\section{A parede E A vara (Hsr. 296, С . 337)}

Uma parede, perfurada furiosamente por uma vara, gritava: "Porque me atacas, se não te fiz mal nenhum?" E aquela disse: "Não sou eu a culpada disto, mas sim aquele que por detrás dá o impulso violento.

\section{O Inverno e a Primavera (Hsr. 297, Сh. 346)}

O Inverno zombava da Primavera e criticava-a por, com o aparecimento dela nada ficar tranquilo, pois um (homem) vai para o prado ou para o bosque: aquele a quem é grato cortar flores, lírios ou rosas e fazê-las girar diante dos olhos e pô-las nos cabelos; outro embarca e sulca o mar, se surge a oportunidade para visitar outros homens, uma vez que já não se preocupa com os ventos ou com a abundante água das chuvas. "Já eu" disse "pareço-me a um líder ou a um déspota e ordeno que não se olhe para o céu, apenas para baixo, para o cháo; imponho o medo e o tremor e, por vezes, que se permaneça resignadamente em casa." "Pois por esse motivo," disse a primavera "os homens vêem-se livres de ti com prazer; por outro lado, quanto a mim, até o meu nome lhes parece belo, por Zeus, o mais belo de todos os nomes, de modo que, quando me vou, recordam-me e, quando apareço, louvam-me."

\section{A pulga e hOMEM (HsR. 358, Сн. 357)}

Certa vez, uma pulga importunava alguém.

E esse, ao apanhá-la: "Quem és tu que mastigas todos os meus membros e me picas sem propósito ou razão?" Ela gritou: "Vivemos assim, não me mates, Pois não posso causar-te grande dano." 
E ele, rindo, falou-lhe deste modo:

"Agora vais morrer pelas minhas mãos."

Porque todo o mal, pequeno ou grande,

Não convém de todo que brote."

A fábula mostra que não se deve compadecer do mal, seja grande ou pequeno.

\section{A pUlga e o boi (HsR. 359, СH. 358)}

Um vez, uma pulga perguntou a um boi o seguinte: "O que aconteceu pare servires diariamente os homens como escravo, sendo tu grande e valente; ao passo que eu rasgo piamente as carnes deles e lhes chupo avidamente o sangue?" E ele: "Eu não sou ingrato com a raça dos mortais, pois eles gostam e cuidam de mim, e coçam-me a fronte e o lombo de forma fabulosa." E ela disse: "Pois para mim, miserável, esse coçar grato para ti, é para mim um fado cruel, se por acaso me acontece."

Os pretensiosos na palavra são até derrotados pelo mais humilde. 


\section{BibliografiA}





\section{EDIÇÓES CRÍTICAS E TRADUÇŌES}

Chambry, Émile (2005), Ésope. Fables. Paris, Les Belles Lettres.

Dufour, Médéric (1967), Aristote. Rhétori que, livre I. (texte établi et traduit). Paris, Les Belles Lettres.

Ferreira, José Ribeiro (2005), Hesiodo. Teogonia. Trabalhos e Dias. Lisboa, INCM.

Gibson, Craig A. (2008), Libanius's Progymnasmata: Model Exercises in Greek Prose composition and Rhetoric. Atlanta, Society of Biblical Literature. pp. 1-8.

Hausrath, A. (1959), Corpus Fabularum Aesopicarum. Vol. I, Fasc. 2. Leipzig, Teubner.

_ (1970), Corpus Fabularum Aesopicarum. Vol. I, Fasc. 1. Leipzig, Teubner.

Júnior, Manuel Alexandre (2005) (trad.), Aristóteles. Retórica. Lisboa, INCM.

Lopes, Rodolfo N. Lopes (2008), Pseudo-Homero. Batracomiomaquia: a guerra das rãs e dos ratos. Coimbra, Fluir Perene.

López, Gonzalo Casildo (2008), Esopo. Fábulas. Madrid, Alianza Editorial.

Leão, Delfim F. (2008), Obras Morais. O banquete dos Sete Sábios. Coimbra, CECH.

Gual, Carlos García; La Peña, P. Bádenas De; Facal, J. López 
(2004), Fábulas de Esopo. Vida de Esopo. Fábulas de Babrio. Madrid, Gredos.

Handford, S. A. (1954), Fables of Aesop: a new Translation. London, Penguin Classics.

Legrand, Ph. E. (1951), Hérodote. Histoires, Livre VII. Paris, Les Belles Lettres.

Marcovich, Miroslav (2008), Diogenis Laertii. Vitae Philosophorvm. Vol. I, Libri I -X. Berlin, Walter de Gruyter.

Most, Glenn W. (2006). Hesiod. Theogony, Works and Days, Testimonia. London, Harvard University Press.

R. Pereira, Maria Helena (2007), Platão. República. (10º edição). Lisboa, Fundação Calouste Gulbenkian.

Perry, Bem Edwin (2007), Aesopica. Chicago, University of Illinois Press.

Ferreira, Nelson Henrique S. (2008), Esopo. Fábulas. Coimbra, Festea.

Sousa e Silva, Maria de Fátima (2006), Aristóteles. História dos Animais, Vol I. Lisboa, INCM.

Sousa e Silva, Maria de Fátima (2008), Aristóteles. História dos Animais, Vol II. Lisboa, INCM.

Valla, Elema Ceva (2012), Esopo. Favole. Milano, Bur Rizzoli. 


\section{Bibliografia Geral}

R. Adrados, Francisco (1979), "The Life of Aesop and the

Origins of Novel in Antiquity", Quaderni Urbinati di Cultura Classica, New Series, Vol. 1, pp. 93-112.

(1993). "Mito y fábula," Emerita 61, pp. 1-14.

R. Adrados, F.; Dijk, Gert-Jan Van (ed.) (1999), History of the Graeco-Latin Fable: Introduction and from the origins to the Hellenistic Age. Vol. 1. Leiden, Brill.

(ed.) (2000), History of the Graeco-Latin Fable: The Fable During the Roman Empire and in the Middle Ages. Vol. 2. Leiden, Brill.

(2003), History of the Graeco-Latin Fable: Inventory and Documentation of the Graeco-Latin Fable, Vol. 3. Leiden, Brill.

Akimoto, Kazuya (2010), Ante-Aesopica: fable traditions of the Ancient Near Eastern Fables. London, UMI / ProQuest.

Allen, James P. (2011), The Debate between a Man and His Soul: A Masterpiece of Ancient Egyptian Literature. Leiden, Brill.

Anthes, Rudolf (1957), "The Legal Aspect of the Instruction of Amenemhet", Journal of Near Eastern Studies, Vol. 16, No. 3, pp. 176-191. 
Ariew, Roger (2011), "Seventeenth-century philosophy", in William Burgwinkle, Nicholas Hammond and Emma Wilson (ed.), The Cambridge History OfFrench Literature. Cambridge, Cambridge University Press. pp. 295-315.

Arnold, Dorothea (1995), "An Egyptian Bestiary", The Metropolitan Museum of Art Bulletin, Vol. 52, No. 4, $1-61$.

Baker, Howard (1969) "A Portrait of Aesop", The Sewanee Review, Vol. 77, No. 4, pp. 557-590.

Bar-Yosef, O. (1980), "Prehistory of the Levant", Annual Review of Anthropology Vol. 9, 101-133.

Bassan, Fernande (1970), "La Fontaine, héritier d' Esope et de Pilpay", Comparative Literature Studies, Vol. 7, No. 2, pp. 161-178.

Beynen, G. Koolemans (1994), "Animal language in the Garden of Eden: folktale elements in Genesis", in Willis Roy (ed.), Signifying Animals: human meaning in the Natural World. London, Routledge.

Brunner, Christopher J. (1980), "The Fable of the Babylonian Tree Part I: Introduction", Journal of Near Eastern Studies, Vol. 39, No. 3, pp. 191-202.

"The Fable of the Babylonian Tree Part II: Translation", Journal of Near Eastern Studies, Vol. 39, No. 4, pp. 291-302.

Bolin, Thomas M. (1999), "History, Histography, and the Use of the Past in the Hebrew Bible", in Genre \& Narrative in Ancient Historical Texts. Leiden, Brill. 
Borthwick, E. K. (2001). "The Cynic and the Statue", The Classical Quarterly, Vol. 51, No. 2, pp. 494-498.

Boys-Stones, G. R. (2003), Metaphor, Allegory, and the Classical Tradition Ancient Thought and Modern Revisions. Oxford, Oxford University Press.

Buchthal, Hugo (1941), "Indian Fables in Islamic Art", Journal of the Royal Asiatic Society of Great Britain and Ireland, No. 4, pp. 317-324.

Budin, Stephanie L. (2004), "A Reconsideration of the Aphrodite-Ashtart Syncretism”, Numen, Vol. 51, No. 2, pp. 95-145.

Cassin, Barbara et Labarrière, Jean-Louis (Eds.) (1997), L'animal dans l'antiquité. Paris, Libraire Philosophique J. Vrin.

Chevalier, Jean ; Gheerbrant, Alain (1982), Dictionaire des Symboles - Mythes, Rêves, Coutumes, Gestes, Formes, Figures, Couleurs, Nombres. Paris, Robert Laffont.

Cirlot, J. E. (2001), A Dictionary of Symbols. Trans. Jack Sage. London, Routledge.

Coenen, Hans Georg (2002), Analogie und Metapher Grundlegung einer Theorie der bildlichen Rede. Berlin, de Gruyter.

Collins, Billie Jean (ed.) (2002), A History Of The Animal World In The Ancient Near East. Leiden, Brill.

Compton, Todd (1990), "The Trial of the Satirist: Poetic Vitae (Aesop, Archilochus, Homer) as Background for Plato's Apology", The American Journal of Philology, Vol. 111, No. 3, pp. 330-347. 
Cons, Louis (J1924), "A Neolithic Saying and an Aesop's Fable", American Journal of Archaeology, Vol. 28, No. 3 pp. 276-277.

Cooper, Kenneth (1955), “Aesop's Fables for Adults” Peabody Journal of Education, Vol. 33, No. 3, pp. 143-147.

Curry, Susan A. (2009), Human Identities and animal others in the second C.E. Indiana University (Department of Classical Studies).

Davies, M. (1981), "Aeschylus and the Fable", Hermes, 109. Bd., H. 2, pp. 248-251.

Daly, L. W. (1961), "Hesiod's Fable", Transactions and Proceedings of the American Philological Association, Vol. 92., pp.45-51.

Demoen, Kristoffel (1997), "A Paradigm for the Analysis of Paradigms: The Rhetorical Exemplum in Ancient and Imperial Greek Theory", Rhetorica: A Journal of the History of Rhetoric, Vol. 15, No. 2, pp. 125-158.

Detienne, M., and J.-P. Vernant (1991), Cunning Intelligence in Greek Literature and Society. Trans. Janet Lloyd. Chicago, University Of Chicago Press.

Dijk, Gert-Jan van (1994), "The Lion and the He-Goat: A New Fable in Procopius", Hermes, Vol. 122, No. 3, pp. 376-379.

(1996), "The Function of Fables in Graeco-Roman Romance”, Mnemosyne, Vol. 49, Fasc. 5, pp. 513-541.

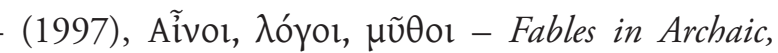
Classical, \& Hellenistic Greek Literature. Leiden, Brill. 
Dillery, John (1999), "Aesop, Isis, and the Heliconian Muses", Classical Philology, Vol. 94, No. 3., pp. 268-280.

Doran, Robert \& Niditch, Susan (1977), “The Success Story of the Wise Courtier: A Formal Approach", Journal of Biblical Literature, Vol. 96, No. 2, pp. 179-193.

Douglas, Mary (1994), "The pangolin revisited: a new approach to animal symbolisim”, in Willis Roy (ed.), Signifying Animals: human meaning in the Natural World. London, Routledge.

Dover, K. J. (1966), “Aristophanes' Speech in Plato's Symposium", The Journal of Hellenic Studies, Vol. 86, pp. 41-50.

Duan, Shu-Jy (1994), A tale of animals: The changing images of animals in animal fantasy for children from Aesop's Fables through 1986. The Ohio State University, PhD - UMI.

Eliade, Mircea (1979), Images et symboles. Essais sur le symbolisme magico-religieux. Paris, Gallimard.

Ehrhardt, Arnold A. T. (1953), "Greek Proverbs in the Gospel”, The Harvard Theological Review, Vol. 46, No. 2, pp. 59-77.

Falkowitz, Robert S. (1983), "Discrimination and Condensation of Sacred Categories: The fable in Early Mesopotamian Literature", in Francisco R. Adrados \& Olivier Reverdin (eds.), La Fable. Genéve, Fondation Hardt.

Falkowitz, Robert S. (1984), The Sumerian Rhetoric Collections. University of Pennsylvania. Phd Dissertation 
Ferreira, Luísa de Nazaré; Rodrigues, Nuno Simóes; Rodrigues, Paulo Simóes (2010), Plutarco e as Artes. Pintura, Cinema e Artes Decorativas. Coimbra, $\mathrm{CECH}$.

Ferreira, Nelson Henrique S. (2011), "A imagética animal no discurso político: a tradição popular em Demóstenes Contra Aristogiton", in Memória \& Sabedoria. Lisboa, Húmus, pp. 523-532.

(2012), A imagética animal e a conceção popular: Um paralelo entre a literatura egípcia e a fábula esópica. Coimbra, Universidade de Coimbra.

Fischel, William A. (1972), “Aesop’s Paradox: The Classical Critique of Democratic Decision Processes", The Journal of Political Economy, Vol. 80, No. 1, pp. 208212.

French, Roger (1994), Ancient Natural History. Histories of Nature. London, Routledge.

G'Enetiot, Alain (2011), "Seventeenth-century poetry", in William Burgwinkle, Nicholas Hammond and Emma Wilson (ed.), The Cambridge History Of French Literature. Cambridge, Cambridge University Press. pp. 284-294.

Gangloff, Anne (2002), "Mythes, fables et rhétorique àl'époque imperial", Rhetorica: A Journal of the History of Rhetoric, Vol. 20, No. 1 pp. 25-56.

R. Gonçalves, Maria Isabel D. S. (1983), Imagens e Simbolos Animais na Poesia Greco-Latina. Lisboa.

Gordon, Edmund I. (1958), "Sumerian Animal Proverbs 
and Fables: 'Collection Five", Journal of Cuneiform Studies, Vol. 12, No. 1, pp. 1-21.

Gragg, Gene (1973), "The Fable of the Heron and the Turtle”, Archiv für Orientforschung, 24. Bd., pp. 51-72.

Grimm, Jürgen (1992), “Diversité Est Ma Devise !': L'art de persuader dans les Fables de La Fontaine", Revue d'Histoire littéraire de la France, 92e Année, No. 2 , pp. 178-197.

Grottanelli, Cristiano (1987), “The Ancient Novel and Biblical Narrative", Quaderni Urbinati di Cultura Classica, Vol. 27, No. 3, pp. 7-34.

Grubmüller, Klaus (1977), Meister Esopus. Untersuchungen zu Geschichte und Funktion der Fabel im Mittelalter. München, Artemis Verlag.

Habermann, Wolfgang (1990), "Ägyptisches und karthagisches leder als antike sortenbezeichnungen”, Rheinisches Museum für Philologie, 133. Bd., H. 2., pp. 138-143.

Hanazaki, Tomoko (1993-1994), "A New Parliament of Birds: Aesop, Fiction, and Jacobite Rhetoric", Eighteenth-Century Studies, Vol. 27, No. 2, pp. 235254.

Hassig, Debra (1995), Medieval Bestiaries: text, image, ideology. New York, Cambridge University Press.

Henderson, A. C. (1973), Moralized Beasts: The development of medieval fable and bestiary, particularly from twelfth through the fifteenth centuries in England and France. Berkeley, Phd UNI. 
(1982), "Medieval Beasts and Modern Cages: The Making of Meaning in Fables and Bestiaries", PMLA, Vol. 97, No. 1, pp. 40-49.

Herder, Johann Gottfried (2006), "On Image, Poetry, and Fable" in Gregory Moore (ed.), Selected Writings on Aesthetics. Princeton, Princeton University Press. Pp. 357-382.

Hibbard, Addison (J1926), "Aesop in Negro Dialect", American Speech, Vol. 1, No. 9 pp. 495-499.

Hoepfner, W.; Schwander, E. L. (1986), Haus und stadt im Klassischen Griechenland: Wohnen in der klassichen Polis I. München, Deutscher Kunstverlag.

Hutton, J. M. (1987), "Growth and Feeding Ecology of the Nile Crocodile Crocodylus niloticus at Ngezi, Zimbabwe", Journal of Animal Ecology, Vol. 56, No. 1, pp. 25-38.

Iriarte, Tomás de (1782), Fábulas completes. Madrid, Brontes. (2013 ed.)

Irwin, Elizabeth (1998), "Biography, Fiction, and the Archilochean ainos", The Journal of Hellenic Studies, Vol. 118, pp. 177-183.

Jedrkiewicz, Stefano (1987), "La favola esopica nel processo di argomentazione orale fino al IV sec. a.C.", Quaderni Urbinati di Cultura Classica, New Series, Vol. 27, No. 3, pp. 35-63.

- (2002), "Animals y sophía. La fábula esópica como saber universal", in Aurélio Pérez Jiménez, Gonzalo Cruz Andreotti (eds.), "Asi dijo la zorra”. La tradición 
Fabulística en los Puebles del Mediterráneo. Málaga, Ediciones Clásicas Madrid.

Jong, Irene J. F. De; Nunlist, René \& Bowie, Angus (Eds.) (2004), Narrators, Narratees, And Narratives In Ancient Greek Literature. Leidein, Brill.

Kennedy, George A. (ed.) (2003), The Cambridge History of Literary Criticism. Vol. 1: Classical Criticism. Cambridge, Cambridge University Press.

Kramer, Samuel Noah (1969), "Sumerian Similes: A Panoramic View of Some of Man's Oldest Literary Images", Journal of the American Oriental Society, Vol. 89, No. 1, pp. 1-10.

Krappe, Alexander H. (1942), "Guiding Animals", The Journal of American Folklore, Vol. 55, No. 218, pp. 228-246.

(1944), "Far Eastern Fox Lore", California Folklore Quarterly, Vol. 3, No. 2, pp. 124-147.

Kreisler, Nicolai von (1971), "An Aesopic Allusion in the 'Merchant's Tale', The Chaucer Review, Vol. 6, No. 1, pp. 30-37.

Kurke, Leslie (2006), "Plato, Aesop, and the Beginnings of Mimetic Prose", Representations, Vol. 94, No. 1, pp. 6-52.

Lambert, W. G. (1996), Babylonian Wisdom Literature. Oxford, Eisenbrauns

Lassere, François (1983), "La fable en gréce dans la poésie archaique", in Francisco R. Adrados \& Olivier Reverdin (eds.), La Fable. Genéve, Fondation Hardt. Pp. 61-103. 
Lefkowitz, Jeremy B. (2009), Aesop's Pen: Adaptation, authorship, and satire in the Aesopic Tradition. University of Pennsylvania. Phd Dissertation ProQuesta LLC

Lenaghan, R. T. (1968), “Steinhöwel's 'Esopus' and Early Humanism”, Monatshefte, Vol. 60, No. 1, pp. 1-8.

Lieb, Ludger; Mohr, Jan; Vögel, Herfried (ed.) (2011), Burkard Waldis: Esopus. 400 Fabeln und Erzählungen nach der Erstausgabe von 1548. Teil 1 \& 2. De Gruyter, Berlin.

Leibried, Erwin (1984), Fabel. Stuttgart, Verlag.

Lidov, Joel B. (2002), "Sappho, Herodotus, and the 'Hetaira', Classical Philology, Vol. 97, No. 3, pp. 203237.

Lindner, Hermann (1977), "VERS LE VRAI LA FONTAINE? Anmerkungen $\mathrm{zu}$ einigen neueren Tendenzen der La Fontaine-Kritik aus Anla $\beta$ des jüngsten Forschungsberichts zu La Fontaines Fabeln”, Zeitschrift für französische Sprache und Literatur, Bd. 87, H. 2, pp. 142-164.

Lhermitte, M. Jean-François (2005), Conscience morale des animaux et perspective ethique dans l'ouvre zoologique d' Elien de Preneste. Universite Paris IV - Paris Sorbone.

Lonslade, H. Steven (1979), "Attitudes towards Animals in Ancient Greece”, Greece \& Rome, Vol. 26, No. 2, 146159.

(1989), "Hesiod's Hawk and Nightingale (Op. 202-

12): Fable or Omen?", Hermes, Vol. 117, No. 4, pp. 403-412. 
Lourenço, Frederico (2005), Homero. Ilíada. Lisboa, Cotovia. (2006), Homero. Odisseia. Lisboa, Cotovia.

Lyons, John D. (1975), "Author and Reader in the Fables", The French Review, Vol. 49, No. 1, pp. 59-67.

Mallory, J. P. \& Adams, D. Q. (2007), The Oxford introduction to proto-indo-european and the proto-indo-european world. Oxford, Oxford University Press.

Marchesi, Ilaria (2005), "Traces of a Freed Language: Horace, Petronius, and the Rhetoric of Fable", Classical Antiquity, Vol. 24, No. 2, pp. 307-330.

Martin, Nilson P. (1972), The Mycenaean origin of greek mythology. Berkeley, University of California Press.

Massing, Jean Michel (1995), "From Greek Proverb to Soap Advert: Washing the Ethiopian", Journal of the Warburg and Courtauld Institutes, Vol. 58, pp. 180201.

McCartney, Eugene S. (1956), "In the Aesopic Tradition", The Classical Journal, Vol. 51, No. 6, pp. 280-281.

Mcdonough, Cristopher (2006), "Ridiculus Mus: of Mice and Men in Roman Thought", in Paul Waldau, Kimberley Patton (eds.), A communion of Subjects: Animals in Religion, Science, and Ethics. New York, Columbia University Press.

Meht, Arti (2007), How The Fables Teach? Reading The World of The Fable in Greek, Latin and Sanskrit Narratives. Indiana University (Department if Classical Studies).

Meskell, Lynn (2000), "Cycles of Life and Death: Narrative 
Homology and Archaeological Realities", in World Archaeology, Vol. 31, No. 3, pp. 423-441.

Michalowski, Piotr (1999), "Commemoration, Writing, and Genre in Ancient Mesopotamia”, in Genre \& Narrative in Ancient Historical Texts. Leiden, Brill.

Miller, Naomi (1968), "The Form and Meaning of the Fontaine des Innocents", The Art Bulletin, Vol. 50, No. 3, pp. 270-277.

Moyes, Craig (2011), "Seventeenth-century prose narrative", in William Burgwinkle, Nicholas Hammond and Emma Wilson (ed.), The Cambridge History Of French Literature. Cambridge, Cambridge University Press. pp. 323-332.

Nagy, Gregory (2003), Homeric Responses. Austin, University of Texas Press.

Newmyer, Stephen T. (2011), Animals in greek and roman thought. New York, Routledge.

Niditch, Susan; Doran, Robert (1977), "The Success Story of the Wise Courtier: A Formal Approach", Journal of Biblical Literature, Vol. 96, No. 2 pp. 179-193

Oldaker, W. H. (1934), "Greek Fables and Babrius", Greece \& Rome, Vol. 3, No. 8, pp. 85-93.

Nøjgaard, Morten (1964), La Fable antique, a fable grecque avant Phèdre. Copenhague.

Ott, K. A. (1959), "Lessing und La Fontaine. Vom Gebrauch der Tiere in der Fabel", GRM 40, pp. 235-266.

Osborne, Catherine (2009), Dumb beasts \& dead philosophers. 
Oxford, Oxford University Press.

Perry, Ben Edwin (1933), “The Text Tradition of the Greek Life of Aesop", Transactions and Proceedings of the American Philological Association, Vol. 64, pp. 198244.

(1934), "The Greek Source of Rinuccio's Aesop”, Classical Philology, Vol. 29, No. 1, pp. 53-62.

(1936), Studies in the text History of the life and Fable of Aesop. Lancaster Press, Oxford.

- (1962), "Demetrius of Phalerum and the Aesopic Fables", Transactions and Proceedings of the American Philological Association, Vol. 93,pp. 287-346.

Penney, J. H. W. (ed.) (2004), Indo-European Perspectives. Oxford, Oxford University Press.

Priest, John F. (1985), "The Dog in the Manger: In Quest of a Fable", The Classical Journal, Vol. 81, No. 1, pp. 49-58.

Pullen, Daniel J. (1992), "Ox and Plow in the Early Bronze Age Aegean”, American Journal of Archaeology, Vol. 96, No. 1, 45-54.

Reed, Charles (1959), "Animal Domestication in the Prehistoric Near East", in A. Science, Vol. 130, No. 3389, 1629-1639.

Reed, Nancy B. (1976), "Griffins in Post-Minoan Cretan Art”, Hesperia, Vol. 45, No. 4, pp. 365-379.

Rihll, T. E. (2003), "Teaching and Learning in Classical Athens", Greece \& Rome, Vol. 50, No. 2, pp. 168-190. 
Rodrigues, Nuno Simóes (2007), "Entre Europa e Io: Elementos Orientais na Arte Grega Arcaica e Clássica”, in Arte Pré-Clássica. Lisboa, APOR. pp. 323-346.

Rothwell, Kenneth S. (1995), "Aristophanes' "Wasps" and the Sociopolitics of Aesop's Fables", The Classical Journal, Vol. 90, No. 3, pp. 233-254.

Rossel, Stine; Marshall, Fiona; Peters, Joris; Pilgram, Tom; D. Adams, Matthew; O'Connor, David (2008), "Domestication of the Donkey: Timing, Processes", Indicators Proceedings of the National Academy of Sciences of the United States of America, Vol. 105, No. 10, pp. 3715-3720.

Rossi, Laura (1999), "Lamentazioni su pietra e letteratura 'trenodica': Motivi topici dei canti funerari", Zeitschrift für Papyrologie und Epigraphik, Bd. 126, pp. 29-42.

Secor, Stephen M. (1995), "Ecological Aspects of Foraging Mode for the Snakes Crotalus cerastes and Masticophisflagellum", Herpetological Monographs, Vol. 9, 169-186.

Schibli, S. Hermann (1983), "Fragments of a Weasel and Mouse War", in Zeitschrift fur Papyrologie und Epigraphik, Bd. 53, 1-25.

Scholar, Richard (2011), "Moraliste writing in the seventeenth century", in William Burgwinkle, Nicholas Hammond and Emma Wilson (ed.), The Cambridge History Of French Literature. Cambridge, Cambridge University Press. pp. 316-322.

Steiner, Deborah (2012), "Fables and frames: the poetics and 
politics of animal fables in Hesiod, Archilochus, and the Aesopica", Arethusa 45, pp. 1-41.

Vermeule, Cornelius (1972), "Greek Funerary Animals, 450300 B. C.”, American Journal of Archaeology, Vol. 76, No. 1, pp. 49-59.

Voultsiadou, Eleni \& Tatolas, Apostolos (2005), “The Fauna of Greece and Adjacent Areas in the Age of Homer: Evidence from the First Written Documents of Greek Literature", Journal of Biogeography, Vol. 32, No. 11, pp. 1875-1882.

Tasopoulou, Evrydiki (2008), The judgment of Animals in Classical Greece: Animal Sculpture and the concept of lifelikeness. Pennsylvania, Bryn Mawr College.

Taylor, Jon (2005), "The sumerian proverb collections", Revue d'Assyriologie et d'archéologie orientale, Vol. 99, pp. 13-38.

Teeter, Emily (2002), "Animals in Egyptian Literature", in Billie Jean Collins (ed.), A History Of The Animal World In The Ancient Near East. Leiden, Brill. Pp. 335-360.

Thite, G. U. (1983), "Indian Fable", in Francisco R. Adrados \& Olivier Reverdin (eds.), La Fable. Genéve, Fondation Hardt.

Z. Tzifopoulos, Yannis (1995), "Proverbs in Menander's "Dyskolos": The Rhetoric of Popular Wisdom", Mnemosyne, Fourth Series, Vol. 48, Fasc. 2, pp. 169-177.

Uther, Hans-Jörg (2006), “The fox in World Literature: 
reflections on a 'Fictional Animal'", in Asian Folklore Studies, Vol. 65, No. 2, pp. 133-160.

Watkins, Calvert (1995), How to Kill a Dragon. Aspects of Indo-European Poetics. Oxford, Oxford University Press.

Weigl, Michael (2010), Die aramäischen Achikar-Sprüche aus Elephantine und die alttestamentliche Weisheitsliteratur. Berlin, De Gruyter.

Wild, J. P. (2002), “The Textile Industries of Roman Britain”, Britannia, Vol. 33, pp. 1-42.

West, M. L. (1997), The East Face of Helicon: West Asiatic Elements in Greek Poetry and Myth. Oxford, Clarendon Press.

(2008), Indo-European Poetry and Myth. Oxford, Oxford University Press.

Williams, Ronald J. (1956) "The Literary History of a Mesopotamian Fable", Phoenix, Vol. 10, No. pp. 7077.

Willis, Roy (1994), "The meaning of the snake", in Willis Roy (ed.), Signifying Animals: human meaning in the Natural World. London, Routledge.

Younger, John G. (2005), Sex in the ancient world from a to $z$. London, Routledge.

\section{Páginas consultadas online:}

http://www.britishmuseum.org (última consulta a 30 de Dezembro de 2012) 
http://www.brooklynmuseum.org/ (última consulta a $30 \mathrm{de}$ Dezembro de 2012)

http://www.louvre.fr/ (última consulta a 30 de Dezembro de 2012)

http://www.metmuseum.org/ (última consulta a 30 de Dezembro de 2012)

http://www.ucl.ac.uk/museums/petrie (última consulta a 30 de Dezembro de 2012)

http://www.paulyonline.brill.nl/ (última consulta a 30 de Julho de 2013) 



\section{INDEX RERVM}

Abelha: 138, 178

Acádicos, textos: 35,40

Acúrcio: 56 n.39

Adivinho: 177 bis

Afrodite: 128. 129, $201 \mathrm{n} .53$

Aftónio: 45, 50 n.30

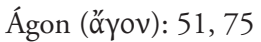

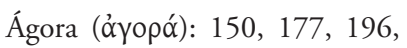
208

Águia: 75, 103, 104 bis, 105, 146, 200, 204, 216

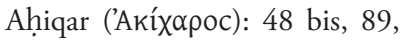
89 n.69

Aî̉’oupoc: 108 n.8

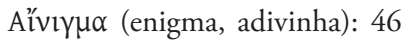
n.19

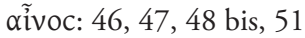

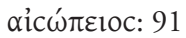

Alcibíades: 81

Alcíone: 117

Aldrabão: 118

Aldus Manutius: 56

Alegoria: 30, 31, 31 n.1, 33, 34, $38,43,44,47,50,51,52$ bis, 52 n.33, 54 (alegórico), 54 bis, 55 (alegórico), 56, 58 bis, 76, 76 n. 58, 82, 86

Alexandre da Macedónia (Magno): 134 n. 25

Alexandria, biblioteca de: 92

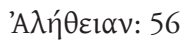

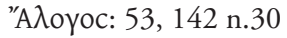

amoreira: 173

Analogia: 24, 25 bis, $31 \mathrm{n} .1$

Anedota: 44, 124 n.20, 213 n.61

Andorinha: 123, 124, 134, 180, 190, 203, 204

Antigo Egipto: 36 bis

Antigo Testamento: 42

Anton von Pforr: 55

Apicultor: 138

Apolo: 153

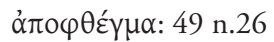

Arado: 123

Arconte: 82, 211, 211 n.59

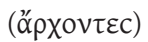

Argumentum: 49 n.26

Arquiloco: 37

Ars Rhetorica: 39

Artesão(s): 152

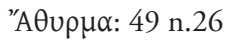


Asarhaddon (Aššur-ahu-iddina): 48

Áspide: 157,158

Assassino: 120

Assíria (Assur): 91 n.70

Assíria, tradição: 40, 43, 89, 91

Astrónomo: 124

Atena: 119, 120, 151, 162

Atenas: 74, 80, 90, 106, 134, 139

Ática: 138, 138 n.28

Atleta: 205

Atum: 115, 157

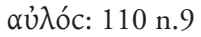

Aurelio Bertola de Giorgi: 49

Avarento: 202

Aviano: 39, 50, 55, 58 bis, 61, 74, 76, 77 bis, 93

Azinheira: 137

Babilónia: 35

Bábrio: 50, 58 bis, 74, 89, 93, 96

Barco: 115, 119, 136, 139, 141, 181, 184, 196

\section{Batracomiomaquia: 33}

Bestiários medievais: 52 n.33

Bezerro: 128

Bode: 109

Boi: 118,118 n.15, 119, 123 bis, 126, 127, 128, 130, $146,153,169,199,224$

Boieiros: 149

Bolotas: 196, 197

Bonus Accursius: 56

Bóreas: 127
Bruxa: 131

Burriqueiro: 186 bis, 187, 188, 220

Burro: 143, 147, 171, 172 bis, 178, 185 bis, 186 bis, 187 bis, 188 bis, 189 bis, 190, 208, 220 bis

Cabra: 103, 107, 129, 172, 175, 200

Cabreiro: 75, 107

Cabrito: 107, 128, 150

Caçador(es): 115, 140 bis, 147, $148,172,202,204,222$ bis

Cadela: 201, 202

Camelo(s): 36, 143, 158, 191, 200, 201, 214

Caminhante: 127, 134, 135, $162,173,181,211,213$

Cana: 137

Cão: 125, 129, 134, 138 (cachorros), 147, 153, 159, 162, 164, 165 bis, 166, 196, 214, 215 bis, 220

Caracol: 130, 215

Caranguejo: 158, 192

Carasso, irmão de Safo: 70

Cária: 89, 91, 205 n.54

Carniceiro: 135, 188, 215

Carpideiras; 195

Carvoeiro: 119

Castor: 159

Cavalo: 143, 153, 174, 222

Caverna: 168, 172, 200, 217

Cego: 123

Cegonha: 191 
Chipre: 89, 91

Cibele: 178 n.44

Cigarra: 187, 210

Cínico, movimento: 79 bis, 80 bis, 80 n. 60,124 n. 24.146 n. 31,213 bis, 213 n.61, 213 n. 62

Cípselo, tirano de Corinto: 88

Ciro, da Pérsia: 60, 111, 111 n. 11

Cisne: 206

Citaredo: 160, 160 n.36

Civilização ocidental: 28

Cobra: 25 bis

Cobra(s) de água: 126, 126 n. 21,146

Comunicação abstracta: 32

Conto de Ahiqar: 219

Conto fantástico ou conto de fadas: 44, 54 bis

Cordeiro: 88, 104, 125, 149, $150,174,219$

Corvo: 161 bis, 162, 163, 177, 177 n.43, 189, 207, 212

Cotovia: 190, 214

Creso: 111, $111 \mathrm{n} .11$

Criança(s): 30, 60 bis, 62, 63, 63 n. 46 (infantil), 148, 159, 175, 177 bis, 192,

Criminoso: 173

Crocodilo(s): 36, 115, 120

O. Crusius: 85

Cultura Acádica: 35

Cultura Egípcia: 43

Cultura Suméria: 35, 43
Curtidor: 195

Damasco: 198

Delfos: 70, 71, 88, 93

Démades, o orador: 80 n. 59, 134

Deméter: 107 n.5, 134

Demétrio (de Fáleron): 44 bis, 74 bis, 80, 91 bis, 93, 94, 94 n. 75,95

Demócrito de Abdera: 90

Der Edelstein: 55

Deus, divindade: 69, 71, 103, 104, 118, 119, 120, 121, $122,128,129,131,135$, 141 bis, $145,150,151,152$ n.33, 155, 156, 163, 178 n. 44, 183 bis, 185, 201 n.53, 205, 209, 219,

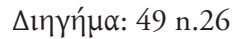

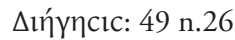

Diógenes: 79, 80, 213 bis

Dioniso: 107 n.7

Dionisias: 107

Dito popular: 47, 92

Dito de Esopo: 91

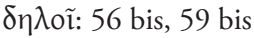

Dracma: 119, 145

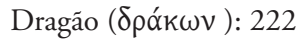

Doente: 108, 118, 131, 168, 180,217

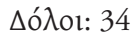

Doninha: 108, 108 n.8, 113, $128,129,132,141,178$, $182,192,211,211$ n.60

Dositeu: 50 n.30, 74 
Eixo (de um carro): 126

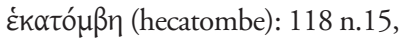
121

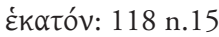

Elefante: 200, 201, 218

Eólios: 111

Escaravelho(s): 36, 88, 104, 105, 144, 154, 156

Escorpião: 193

Escravo: 68 n.48, 70, 112, 119 n. $16,131,149,178,224$

Escultor: 118, 145, 146

Esopo: 40 bis, 41 n. 9, 43, 45, 46 n.20, 59 n. $41,67-72,73$ bis, 74, 79, 87 bis, 90, 91 bis, 92, 93 bis, 108, 134

Esopo de Ulm: vide Heinrich Steinhöwel

Espinho: 219

Espinheiro: 181

Estesícoro: 45, 60

Estômago: 164

Etana, mito: 35

Ética: 28

Exemplum(a): 44 bis, 49 n.26, 55 n. 37, 61, 69,

Fabella: 49 n.26

Fabula: 49 n.26

Fábula: passim

Fábula acádica

"A águia e a cobra": 35

"O mosquito e o elefante": 36

Fábulas de disputa argumentativa: 75

Fábulas de situação: 75
Fábula esópica: passim

Fábulas etiológicas: 75

Fábula medieval: 39

Fábulas sumérias

"A garça e a tartaruga": 35

"Burro e cão": 35

"Cáo e figo": 35

"Dez lobos": 35

"Leão e cabra": 35

Facete dictum: 56

Falcão: 75, 105, 106

Fanfarrão: 121

Fauna: 32

Fedro: 38, 39 bis, 40 bis, 40 n. 8 bis, 49, 50, 58, 61, 68 bis, 73, 74, 76, 93

Felix domesticus: 108 n.8

Félix María de Samaniego: 49

Figueira: 219

Formiga: 156, 179, 207

Fortuna: 133, 137, 141, 172, 180, 183, 183 (divindade), 115

Frígia: 68

Funeral: 157

Gaia: 152

Gaivota: 167, 181

Galinha: 108, 132, 145, 190

Galo: 113, 116, 131, 143, 160, 214, 215, 218

Ganso: 204

Garça: 175, 204

Gato: 108 n.8

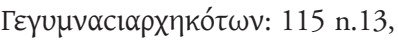
vide gimnasiarcas 
Géneros literários

Épico: 27, 33, 33 n.2, 62

Tragédia: 62, 118

Romance: 48 bis (novela), 62, 67, 69, 69 (novela), 70,

Gian Carlo Passeroni: 49

Gimnasiarcas: 115

Golfinho: 133, 138, 139, 157, 170

Golião: 133

Gottfriedus Hauptmann: 56

Gralha: 104, 146, 151, 161, 162 bis, 163 bis, 164, 194, 200, 204

Grimm (Jacob e Wilhelm): 49

J. Grimm: 85

Gruta: 107, 140, 200

Heinrich Steinhöwel: 55

Hélade: 27

Cultura helénica, grega: 28 bis, 70 bis

Arcaica: 46, 68 n. 48

Hélios: 127

Hera: 145

Héracles: 156, 205

Herder: 85

Hermes: 145 bis, 146 bis, 150, 152 bis, 154, 182, 183, 185 bis

Hérmogenes: 45

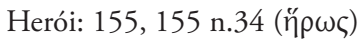

Hesíodo: 37

Hidra (cobra de água): 126 n.21, 146,147
Hiena: 210 bis

Hímera: 45

Historia: 49 n.26

Homero: 46 n.17, 67

Hortelão: 148, 159 bis

Iádmon: 70

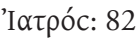

Imagética (animal, mundo natural): $31-4,52$ bis, 53 , $54,76,88$,

Imago: 49 n.26

Infantil (imaginário): 54, 55, 61 (literatura), 62, 63, 63 n.46

Inimigo: 103, 117, 130, 136, $138,143,163,166,173$, $176,199,206,222$

Inverno: 122, 144, 148, 153, 156, 180, 184, 204, 223

Iocus: 49 n.26

Iónios: 111

Isaac Nicolaus Neveletus: 56

Istar: $201 \mathrm{n} .53$

'Ictopía: 49 n.26

Jardineiro: 185

Javali: 202, 222

Jean de la Fontaine: 30, 38, 42, 49, 49 n. 29,54 bis, 55, 55 n. 36,62 n. 45,73 bis, 85 , 85 n.61

Jean-Pierre Claris de Florian: 49 Jogos Olímpicos: 121 Johan Hurus: 56 n.40 Juramento (divindade): 209

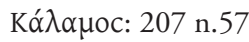

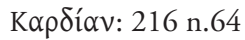


Konrad of Hirsau: 61

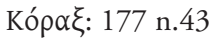

Кратท́р: 194 n.52

Ladrão: 125, 128, 160, 193, 199

Larva: 222

Lavrador: 123, 125, 129 bis, 130 bis, $133,167,168,169,199$

Latim

Classico: 77

vulgar: 77

Leão: 110, 128, 137 bis, 139, $140,143,164,165,167$, 168 bis, 169 bis, 170 bis, 171 bis, 172 bis, 189, 190, 200, 216, 217 bis, 218 bis

Leoa: 217

Lebre: 104, 166, 167, 171, 203, 216

$\Lambda \varepsilon ́ \gamma \omega: 46$ n.16

Leitão: 201

Lenhador: 115, 116, 182

Leopardo: 111

Levante, região: 35

Lessing: 85 bis

Libânio: 50 n.30

Líbano: 219

Líbia: 89, 91

Lídia: 91, 93, 205 n.54

Lídios, povo: 111

Lima: 132

Linguagem popular: 33

Lobo: 59, 81, 113 n.12, 120, 123 bis, 123 (lobacho), 149, 150 bis, $165,173,174$ bis, 175 bis, 176, 188, 189,
197, 206, 217, 218, 261, 267

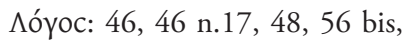
59

$\lambda o ́ \gamma \omega v$ Aicc $\omega \pi \varepsilon i ́ \omega v: 91$

Lorenzo Pignotti: 49

Lorenzo Valla: 56 n.39 e n.40

Luigi Fiacchi: 49

Macaco(s): 36, 93, 112, 138, 139, 142, 143, 195, 200 bis

Machado: 129, 135, 136, 182, 183

Malta, ilha: 138

Manhoso: 122

Mar: 138,138 n. 28, 140, 141, $158,167,170,180,181$, 196, 223

Marinheiro(s): 138, 141, 158, 170

Máscara: 118

Matriz cultural: 24, 27 bis, 28 (ocidental), 41(ocidental), 47 n.23 (judaico-cristã), 61 (europeia)

Máxima(s): 59

Meandro: 82, 205

Médico: 82, 108, 121, 131, 157, $180,181,188,217$

Mediterrâneo, regiáo do: 36 (bacia do), 43, (antigo) 201 n. 53

Menargitas: 178

Mesopotâmia, antiga: 35, 36, 38, 91 n. 70,201 n. 53

Metáfora: 31, 31 n.1, 32 bis

K. Meuli: 85 
Mileto: 58, 82 bis, 205, 205 n. 54

Milhafre: 167

Mirtilos: 145

Mistérios: 107

Momo (divindade): 151

Moral: 28 bis, 29

Moralidade: 23, 24, 28, 29 bis, $33,34,50,51,52,53,57$, $58,61,75$ bis, 79,81 bis, 121 n. 17,122 n. 19

Morcego: 128, 181, 182

Morte: 103, 125, 131, 133, 136, $157,158,173,179,184$, 192, 194, 205, 206, 214, 219

Mosca: 142, 179

Mosquito: 166, 216, 218

Mula: 186, 220

Mṽ日oc: 46, 48, 56, 59, 60

Narratio: 49 n.26

Narrativa sapiencial: 41

Náufrago: 119, 120, 180

Neniae: 49 n.26

Nilo, vale do: 35-36, 120 (rio)

Nogueira: 214

Oleiro: 148,185

Oliveira: 219

Oráculo: 122

Oratória (grega): 60

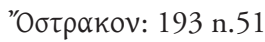

oü $\omega$ : 56, 59

Ovelha: 123, 129, 144, 169, 173, 176 bis, 196 bis, 197 bis, 198 bis, 206, 221
Palmeira: 88

Panateneias: 107

Papagaio: 211

Parábola: 41, 42 bis, 42 n.10, 43 bis, 44, 49, 49 n.26

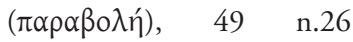
(parábola) 85 n.62

П $\rho \alpha \delta \varepsilon i ́ \gamma \mu \alpha \tau \alpha: ~ 45,49$ n.26

Pardal: 122

Parra: 140

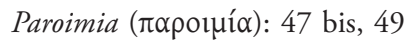
n. 26

Passarinheiro: 145, 157, 190, 191 bis, 207, 208 bis, 220 bis,

Pássaro (ave): 104, 105, 106, $117,123,124,146,151$, 161, 167, 177, 182, 190, 191, 200, 207, 214, 215

Pastor: 23 (pastoreio), 104, 107, 117. 144, 148, 196 bis, 197 bis, 206, 221, 222,

Pavão: 200

Perdiz: 116, 199

Período Helenístico: 36

Perséfone: 107 n.5

Persas: 111

Perses: 106

Pés: 164

Pescador: 110, 111, 112, 114, 115, 118, 195

Pisoador: 119

Пíctıc: 45

Plátano: 183

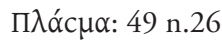




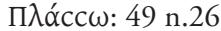

Pluto: 156

Primavera: 204, 223

$\pi \rho o ̀ c: ~ 60$ bis

Poemas homéricos: 67

\section{Iliada: 27}

Política: 29, 60, 61 bis (invectiva), 71, 80 n.60, 82, 87, 89, 118 n.118 (invectiva), 160 (carreira), 177 n. 42 (actividade),

Pólis: 60, 61, 80 n. 60, 81 bis, 87 bis, 89,177 n. 42,211 n. 59

Pombos: 163, 208

Porca(o): 106, 107, 144, 201, 202

Progymnasmata: 39, 54

Prometeu: 118, 151, 185, 190, 209, 218, 221

Prostituta: 120

Provérbio: 44, 47 bis, 47 n.23, 85 n.61, 214 n.63

Pudor: 76, 155

Pulga: 205, 223, 224

Raposa: 33 bis, 52, 58, 59, 82, $103,109,110,111,112$, 113 bis, 114 bis, 115 bis, $116,117,118,123,125$, 142, 149, 154, 158, 161 bis, $162,164,168,170,171$ bis, 172, 189, 190, 202, 205, 210 bis, 214, 215, 216, 217 bis

Rã: 125, 126, 136, 146 n.31, $147,167,189$

Rato: 88, 129, 141, 170, 172,
178, 179, 182, 192

Rebanho: 123, 125, 144, 149 bis, 169, 173, 196 bis, 197 bis, 206, 221

Recensão Augustana: 96, 97

Rei: 111, 126, 142, 151, 200 bis, 201, 219

Retórica: 32, 35, 39, 42 bis, 44, 45 bis, 45 n.15, 48, 54, 61, $73,85,93,160$ n.37,

Rinuccio da Castiglione de Arezzo (Remicius Aretinus): 56 n.39

Rio: 82, 118, 120, 127, 134, $149,165,166,174,176$, $182,183,185,186,188$, 195, 198, 205, 205 n.54, 213

Rodes: 121

Rodópis: 70, 70 n. 53

Romã: 198

Rómulo: 50 n.30

Rouxinol: 75, 105, 106, 128

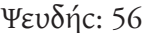

Safo: 70 bis

Sales: 49 n.26

Sâmios, assembleia dos: 71

Samos, ilha: 45, 70

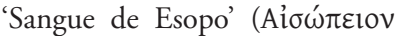

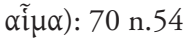

Sapateiros: 152

Sapos: 88

Sardes: 111

Sardis: 93

Sátiro: 122 
Semónides

IEG fr. 8-9: 60

Sennacherib (Sîn-ahhēē-erība): 48

Senso-comum: 25, 30, 32, $33,34,59,60$

Sentença (sententia): 33, 48, 50 n. $32,51,56$ bis, 57 bis, 58 bis, 59, 60, $61 \mathrm{n} .43,75$ bis, 81 bis, 82 bis, 92, 95, 110 n. 10,118 n. 14,121 n. 17

Serpente:120, 129, 163, 163 n.40, 190, 191, 192 bis, 193, 199, 201, 203

Sibáris: 89, 91

Sicília: 60, 81

Signo(s): 31 bis, 52,53 bis

Silva: 114,198

Símbolo(s) popular(es) (animal): 32 bis, 53 bis, 59 bis , 88 (simbolismo animal)

Similitudo: 42, 49, 49 n.26

Symposium: 87 bis, 87 n.64

Síntipas: 74, 94 n.74

Síria: 70 n.91

Sociedade(s) complexa(s): 28

Sócrates: 71

Sumérios, textos: 35,40

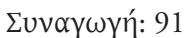

Súnio: 138

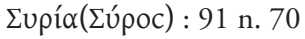

Tâmara: 185, 196

Tartaruga: 154, 203, 204

Tempestade: 107, 119, 136, 139, 141, 181, 196

Teofrasto: 90
Teón de Alexandria: 39, 45

Tertium comparationis: 51

Tirésias: 146

Tojo: 184

Tomás de Iriarte: 49

Tommaso Crudeli: 49

Tordo: 145

Toupeira: 199

Touro: $128,144,151,158,166$, $169,170,200$

Trácia: 68

Tradição (popular): 27 bis, 28, 29, 33

Tradição esópica: 40 n.6, 65-100

Tradiçấo ocidental: 43, 45

Tú

Túxๆ: 183 n.47

"Ү $\rho \rho \circ$ (

úró $\rho \chi \omega v: 104$ n.2

Urbanitates: 49 n.26

Urso: 134, 135, 170

Uvas: 113

Vaqueiro: 128

Veado: 139, 140 bis, 170, 171

Vendedor (de estátuas): 150

Verdade: 76

Vergonha: 76

Vespa: 199 bis

Viajante: 87, 127, 162, 183 bis, 184 bis, 185, 207

Víbora: 146, 147, 148, 149, 184

Vida de Esopo: 48, 56 n.39, 67, 69

Vita Aesopica: Vida de Esopo 
INDEX RERVM

W. Wienert: 85

Zeus: 104, 105, 108, 126, 128, 145,151 bis, 152 bis, 153

bis, 154 bis, 155, 156, 158,

$178,179,185$ bis, 187,193 , 201, 209, 223

Zwóv: 53 


\section{INDEX LOCORVM}

Aesopica

F. 1: 57

F. 2: 57

F. 3: 46 n.18, 71, 75 bis

F. $4 \mathrm{~b}: 46,75$

F. 6: 75

F. 7: 75

F. 8: 68

F. $18: 105$ n. 3

F. 26: 82

F. $28: 121 \mathrm{n} .18$

F. 32: 36

F. $33: 57,127$ n. 24

F. 46: 30

F. $63: 60,68,80$

F. $81: 53$ n. 34

F. $83: 53$ n.34

F. 107: 53 n. 34

F. $135: 80$

F. 130: 57

F. 153: 81

F. $155: 113$ n.12

F. 170: 82

F. $188: 53$ n. 34

F. $220: 53$ n. 34
F. 228: 81

F. $232: 58,82$

F. 242122 n. 19

F. $243: 61,82$

F. 247: 79

F. $259: 36$

Aftónio

Hsr. II pp. 133-51: 93

Aristófanes

Aves

471-3: 86 n.63

474 ss.: 41

$\mathrm{Paz}$

1063-86: 88

Vespas

1258-62: 89

1401ss et all: 41

1427ss: 60

1446-8: 71 n.55

Aristóteles

Retórica

Rh. 2. 20: 41, 42, 45

Rh. 1393a. 23: 45

Rh. 1393b: 60

Rh. 1413a 15-17: 47 
Arquíloco: 46 n. 18

IEG fr. 172-81: 60

IEG fr. 185-87: 60

Bábrio

Prologo 2. 2: 89 n.68

Biqueirão: 114

Bodleianus Auct. F. 4 (vide Palatinus quintus): 96

Burkard Waldis

Esopus: 55

Canisensis 94, vide. Pap.

Vindob. 130

Calímaco

Fr. 192, 15-7: 71 bis, 93

Fr. 194: 219 n.66

Fr. 194, 7-8: 92 n.72

Camaleão

Hsch. II 595.46: 89 n.67

Christian Fürchtegott Gellert

Fabeln und Erzählungen: 62 n. 45

Diógenes de Laércio

5. 26ss: 47

5. $50: 48$

5.79-81: 91

5.80-1: 74

Énio

Saturae 21-58: 49

Ésquilo

Perry 276a, Fr. 139: 41 Fedro

Fabulae Asopiae: 73

1. Pro. 1-2: 68 n. 49
1 Pro. 1-69: 49

3.29: 68

4 Pro. 11-2: 91

Heraclito

Allegoriae $(=$ Quaestiones Homericae): 44 n. 11

Heródoto

Historiae

1.141: 41,60

2. $134.3: 41,70$

Hesíodo

Opera

202: 46

202-212: 41, 61

Ión de Chios

$\operatorname{Tr} G F$ fr. 38.36: 89 n.66

Ivan Krylov

Basni: 62 n. 45

Juizes

9.8 ss: 219

Lessing

Vom dem Wesen der Fabel: 42 bis

Libânio

Inst.

5. 11: 42

1.1.1-1.3.4: 39

Laurentianus 79 (Accursiana): 96 Monacensis 564, Augustanus: 96

Palatinus quintus: 96

Panchatantra 4. 8: 189 n.48

Papyrus Berlin 3024: 138 n.27 
Platão

Alcibiades I

123a: 41,61 n.42

Fédon

$60 \mathrm{~b}$ et al: 41,71

60c 1-7: 69 n. 50

61a: 89

$82^{\text {a: }} 89$ n. 66

84e-85b: 206 n. 55

Theaeteto 174a: 124 n.20

Plutarco

Moralia

147b: 87

399s: 88

Banquete dos Sete Sábios: 87

Poemas homéricos

Ilíada

XXIII, v. 652: 47

XXIII, v. 795: 47

Odisseia

XIV, v. 509: 47

Procópio

Bella 1.3.13: 94

Ps.-Dositeu

16f., Hsr. II pp. 120-9: 93

Ps.-Hermógenes

p. 2.15 f: 93

Quintiliano

Inst. 11.19.1-4: 46 n.20

Rousseau, Jacques

Émile II: 55 n.36

Rylands 493 vide Monacensis

564: 96
Simónides: 46 n. 18

Semónides

$I E G$ fr. 8-9: 60

Sófocles

Ajax 1142-58: 41

Antígona 712-14: 137 n.26

Suda I 332.1: 71

Teócrito 14. 43: 47

Téon

Progymnasmata

72. 27 ss: 45 n. 13

72.28: 39

73. 1-15: 91

73. 3-5: 91

73. 24-33: 50 n.30

Vindobonense (Pap. Vindob. 130): 96

Timocréon de Rodes

PMG 730: 89

PMG 734: 89

Trivultianis 775: 97 n.78

$\operatorname{Tr} G F$ 139: 89

Vaticanus 777: 97 n.78

Waldis, Burkard

Esopus: 55

Xenofonte

Men. 2.7.11: 41 



\section{INDEX FABULARUM}

A águia, a gralha e o pastor (Hsr. 2, Ch. 5)

A águia e a raposa (Ch. 3, Hsr. 1)

A águia e o escaravelho (Hsr. 3, Ch.4)

A andorinha e a gralha (Hsr. 258, Ch. 348)

204

A andorinha e a serpente (Hsr. 255, Ch. 347)

203

A andorinha e os pássaros (Hsr. 39, Ch. 349)

A azinheira e a cana (Hsr. 71, Ch. 101)

A bruxa (Hsr. 56, Ch. 91)

A cigarra e a raposa (Hsr. 245, Ch. 335)

210

A cotovia (Hsr. 271, Ch. 169)

214

A criança e o corvo (Hsr. 171, Ch. 294)

A doninha e Afrodite (Hsr. 50, Ch. 76)

128

A doninha e a lima (Hsr. 59, Ch. 77)

A doninha e o galo (Hsr. 16, Ch. 12)

A doninha e os ratos (Hsr. 81, Ch. 13)

A doninha médica e as galinhas (Hsr. 7, Ch. 14)

A formiga (Hsr. 175, Ch. 242)

A formiga e o escaravelho (Hsr. 114, Ch. 241) 156

A formiga e o pombo (Hsr. 176, Ch. 242) 207

A gaivota e o milhafre (Hsr. 144, Ch. 193) 167

A galinha dos ovos de ouro (Hsr. 89, Ch. 288d) 145

A galinha e a andorinha (Hsr. 206, Ch. 286) 190

A gralha e a raposa (Hsr.128, Ch. 160) 
A gralha e o cão (Hsr. 129, Ch. 127) 162

A gralha e o corvo (Hsr. 127, Ch. 170) 162

A gralha e os corvos (Hsr. 125, Ch. 161) 161

A gralha e os pássaros (Hsr. 103, Ch. 162) 151

A gralha e os pombos (Hsr. 131, Ch. 163) 163

A gralha fugida (Hsr. 133, Ch. 164) 164

A hiena e a raposa (Hsr. 241, Ch. 341) 210

As hienas (Hsr. 240, Ch. 340) 210

A leoa e a raposa (Hsr. 167, Ch. 194) 217

A larva e o dragão (Hsr. 237, Ch. 33) 222

A mosca (Hsr. 177, Ch. 238) 179

A mulher e a galinha (Hsr. 58, Ch. 90) 132

A mulher e o marido bêbado (Hsr. 278, Ch. 88) 212

A mulher e os escravos (Hsr. 55, Ch. 89) 131

A nogueira (Hsr. 141, Ch. 152) 214

A ovelha tosquiada (Hsr. 232, Ch. 321) 198

A parede e a vara (Hsr. 296, Ch. 337) 223

A pomba e a gralha (Hsr. 218, Ch. 302) 194

A porca e a cadela I (Hsr. 250,Ch. 342) 201

A porca e a cadela II (sobre a fecundidade) (Hsr. 251, Ch. 342)

A primeira vez que um camelo foi visto (Hsr. 210, Ch. 148) 191

A pulga e homem (Hsr. 358, Ch. 357) 223

A pulga e o atleta (Hsr. 260, Ch. 256) 205

A pulga e o boi (Hsr. 359, Ch. 358) 224

A romã, o damasco e a silva (Hsr. 233, Ch. 324) 198

A raposa com o ventre inchado (Hsr 24, Ch. 30) 117 
A raposa e a máscara (Hsr. 27, Ch. 43) 118

A raposa e a silva (Hsr. 19, Ch. 31) 114

A raposa e as uvas (Hsr. 15, Ch. 32) 113

A raposa e o bode no poço (Hsr. 9, Ch. 40) 109

A raposa e o crocodilo (Hsr. 20, Ch. 35) 115

A raposa e o lenhador (Hsr. 22, Ch. 34) 115

A raposa e o leopardo (Hsr. 12, Ch. 37) 111

A raposa e o macaco discutiam acerca da linhagem (Hsr 14, Ch. 39)

A raposa que acaricia um cordeirinho e o cão (Hsr. 41 , Ch. 36)

A raposa que avistou um leão (Hsr.10, Ch. 42) 110

A raposa sem cauda (Hsr. 17, Ch. 41) 113

A serpente, a doninha e os ratos (Hsr. 212, Ch. 289) 192

A serpente e o caranguejo (Hsr. 211, Ch. 290) 192

A serpente que foi pisada e Zeus (Hsr. 213, Ch. 291) 193

A tartaruga e a águia (Hsr. 259, Ch. 351) 204

A tartaruga e a lebre (Hsr. 254, Ch 352) 203

A toupeira (Hsr. 234, Ch. 326) 199

A velha e o médico (Hsr. 57, Ch. 87) 131

A víbora e a hidra (cobra de água) (Hsr. 92, Ch. 117) 146

A víbora e a lima (Hsr. 95, Ch. 116) 148

A víbora e a raposa (Hsr. 98, Ch.115) 149

A vespa e a serpente (Hsr. 236, Ch. 331) 199

As abelhas e Zeus (Hsr. 172, Ch. 234) 178

As árvores e a oliveira (Hsr. 293, Ch. 252) 219

As crias de macaco (Hsr. 243, Ch. 307) 200 
As duas algibeiras (Hsr. 229, Ch. 303) 221

As lebres e as raposas (Hsr. 169, Ch. 190) 216

As lebres e as rãs (Hsr. 143, Ch. 191) 167

As moscas (Hsr. 82, Ch. 239) 142

As raposas no rio Meandro (Hsr. 231, Ch. 29) 205

As rãs em busca de um rei (Hsr. 44, Ch. 66) 126

As rãs que procuravam água (Hsr. 43, Ch. 68) 125

As rãs vizinhas (Hsr. 70, Ch. 67) 136

As vespas, as perdizes e o lavrador (Hsr. 235, Ch. 330) 199

Bóreas e Hélios (Hsr. 46, Ch. 73) 127

Démades, o orador (Hsr. 63, Ch. 96) 134

Diógenes e o careca (Hsr. 65ª Ch. 97) 213

Diógenes em viajem (Hsr. 65, Ch. 98) 213

Esopo num estaleiro (Hsr. 8, Ch. 19) 108

Héracles e Pluto (Hsr. 113, Ch. 130) 156

Hermes e Gaia (Hsr. 104, Ch. 109) 152

Hermes e o escultor (Hsr. 90, Ch. 108) 145

Hermes e os artesãos (Hsr. 105, Ch. 111) 152

Hermes e Tirésias (Hsr. 91, Ch. 110) 146

O adivinho (Hsr. 170, Ch. 233) 177

O alcíone (Hsr. 25, Ch. 28) 117

O apicultor (Hsr. 75, Ch. 235) 138

$\mathrm{O}$ assassino (Hsr. 32, Ch. 45) 120

$\mathrm{O}$ astrónomo (Hsr. 40, Ch. 65) 124

$\mathrm{O}$ atum e o golfinho (Hsr. 115, Ch. 132) 157

$\mathrm{O}$ avarento (Hsr. 253, Ch. 344) 202

O burro comprado na ágora (Hsr. 200, Ch. 263) 208 
O burro, a raposa e o leão (Hsr. 203, Ch. 270) 190

O burro disfarçado com pele de leão (Hsr. 199, Ch. 267) 189

O burro e a mula I (Hsr. 192, Ch. 265) 186

O burro e a mula II (Hsr. 204, Ch. 272) 220

O burro e as cigarras (Hsr. 195, Ch. 278) 187

O burro e as rãs (Hsr. 201, Ch. 271) 189

O burro e o burriqueiro (Hsr. 197, Ch. 277) 188

O burro e o cão que viajavam juntos (Hsr. 295, Ch. 276) 220

O burro e o jardineiro (Hsr. 190, Ch. 273) 185

O burro, o corvo e o lobo (Hsr. 202, Ch. 274) 189

O burro, o galo e o leão (Hsr. 84, Ch. 269) 143

O burro que brincava e o amo (Hsr. 93, Ch. 275) 147

O burro que carregava uma estátua (Hsr. 193, Ch. 266) 186

O burro que carregava sal (Hsr. 191, Ch. 265) 185

O burro selvagem e o doméstico (Hsr. 194, Ch. 264) 187

O cabreiro e as cabras selvagens (Hsr. 6, Ch. 17) 107

O cabrito que estava em casa e o lobo (Hsr. 100, Ch. 106) 150

O camelo dançarino (Hsr. 142, Ch. 147) 214

O camelo, o elefante e o macaco (Hsr. 246, Ch. 145) 200

O camelo que queria ter cornos (Hsr. 119, Ch. 146) 158

O cão adormecido e o lobo (Hsr. 137, Ch. 184) 165

O cão e o caracol (Hsr. 265, Ch. 181) 215

O cão e o carniceiro (Hsr. 134, Ch. 183) 215

O cão e a lebre (Hsr. 139, Ch. 182) 166

O cão, o galo e a raposa (Hsr. 268, Ch. 180) 214

O cão perseguidor do leão (Hsr. 135, Ch. 187) 164

O cão que trazia um naco de carne (Hsr. 136, Ch. 185) 165 
O caranguejo e a raposa (Hsr. 118, Ch. 150) 158

O carvoeiro e o pisoador (Hsr. 29, Ch. 56) 119

O castor (Hsr. 120, Ch. 153) 159

O cisne e o amo (Hsr. 247, Ch. 174) 206

O citaredo (Hsr. 123, Ch. 156) 160

O cordeiro e o lobo flautista (Hsr. 99, Ch. 107) 149

O corvo e a raposa (Hsr. 126, Ch. 165) 161

O corvo e a serpente (Hsr. 130, Ch. 167) 163

O criminoso e a amoreira (Hsr. 157, Ch. 214) 173

O devedor ateniense (Hsr. 5, Ch. 10) 106

O doente e o médico (Hsr. 180, Ch. 249) 180

O estômago e os pés (Hsr. 132, Ch. 159) 164

O golfinho e o macaco (Hsr. 75, Ch. 305) 138

O herói (Hsr. 112, Ch. 131) 155

O homem aldrabão (Hsr. 28, Ch. 55) 118

O homem cego (Hsr. 37, Ch. 54) 123

O homem cobarde que encontrou um leão de ouro (Hsr. 72, Ch. 62)

O homem e o sátiro (Hsr. 35, Ch. 60) 122

O homem fanfarrão (Hsr. 33, Ch. 51) 121

O homem grisalho e as duas prostitutas (Hsr. 31, Ch. 52) 120

O homem manhoso (Hsr. 38, Ch.64) 122

O homem mordido por um cão (Hsr. 64, Ch. 177) 134

O homem que prometia o impossível (Hsr. 34, Ch. 46) 121

O hortelão e o cão (Hsr. 122, Ch. 155) 159

O hortelão que regava hortaliças (Hsr. 121. Ch. 154) 159

O inverno e a primavera (Hsr. 297, Ch. 346) 223 
O javali e a raposa (Hsr. 252, Ch. 327) 202

O javali, o cavalo e o caçador (Hsr. 238, Ch. 328) 222

O jovem libertino e a andorinha (Hsr. 179, Ch. 248) 180

O Juramento (Hsr. 214, Ch. 298) 209

O lavrador e a serpente (Hsr. 51, Ch. 81) 129

O lavrador e o lobo (Hsr. 38, CH. 64) 123

O lavrador e os cães (Hsr. 52, Ch. 80) 129

O lavrador e os filhos (Hsr. 42, Ch. 83) 125

O leão apaixonado (Hsr. 145, Ch. 198) 167

O leão aprisionado e o lavrador (Hsr. 149, Ch. 197) 169

O leão assustado por um rato (Hsr. 152, Ch. 213) 170

O leão doente, o lobo e a raposa (Hsr. 269, Ch. 205) 217

O leão e a lebre (Hsr. 153, Ch. 204) 171

O leão e a Rã (Hsr. 147, Ch. 201) 168

O leão e o burro que caçam juntos (Hsr. 156, Ch. 208) 172

O leão e o golfinho (Hsr. 150, Ch. 202) 170

O leão e o rato reconhecido (Hsr.155, Ch. 206) 172

O leão e o touro (Hsr 148, Ch. 111) 169

O leão e o urso (Hsr. 152, Ch. 200) 170

O leão envelhecido e a raposa (Hsr. 147, Ch. 196) 168

O leão, o burro e raposa (Hsr.154, Ch. 209) 171

O leão, Prometeu e o elefante (Hsr. 292, Ch. 210) 218

O lenhador e Hermes (Hsr. 183, Ch. 253) 182

O lobo e a cabra (Hsr. 162, Ch. 220) 175

O lobo e a garça (Hsr. 161, Ch.224) 175

O lobo e a ovelha (Hsr. 164, Ch. 230) 175

O lobo e a velha (Hsr. 163, Ch. 223) 175

O lobo ferido e a ovelha (Hsr. 166, Ch. 231) 176

O lobo e o cavalo (Hsr. 19, Ch. 225) 174 
O lobo e o cordeiro (Hsr. 160, Ch. 221) 174

O lobo e o cordeiro (Hsr. 161, Ch. 222) 219

O lobo e o pastor (Hsr. 165, Ch. 229) 206

O lobo gabarola e o leão (Hsr. 210, Ch. 219) 218

O lobo médico (Hsr. 198, Ch. 281) 188

O macaco e o camelo que dançavam (Hsr. 85, Ch. 306) 143

O macaco e os pescadores (Hsr. 219, Ch. 304) 203

O macaco, que foi eleito rei, e a raposa (Hsr. 83, Ch.38) 142

O marido e a mulher problemática (Hsr. 97, Ch. 49) 149

O médico no funeral (Hsr. 116, Ch. 134) 157

O medricas e os corvos (Hsr. 290, Ch. 47) 212

O menino ladrão e a mãe (Hsr. 216, Ch. 296) 193

O menino que tomava banho (Hsr. 230, Ch. 297) 211

O morcego e as doninhas (Hsr. 182, Ch. 251) 182

O morcego, o espinheiro e a gaivota (Hsr. 181, Ch. 250) 181

O mosquito e o leão (Hsr. 267, Ch. 188) 216

O mosquito e o touro (Hsr. 140, Ch. 189) 166

O náufrago e Atena (Hsr. 30, Ch. 53) 119

O náufrago e o mar (Hsr. 178, Ch. 245) 180

O pai e as filhas (Hsr. 96, Ch. 299) 148

O papagaio e a doninha (Hsr. 261, Ch. 355) 211

O passarinheiro e a áspide (Hsr. 117, Ch. 137) 157

O passarinheiro e a cegonha (Hsr. 208, Ch. 284) 191

O passarinheiro e a cotovia (Hsr. 207, Ch. 283) 190

O passarinheiro e a perdiz (Hsr. 205, Ch. 285) 220

O passarinheiro e os pombos (Hsr. 209, Ch. 282) 208

O pastor brincalhão (Hsr. 226, Ch. 318) 197

O pastor e as crias do lobo (Hsr. 225/Ch. 313) 197

O pastor e as ovelhas (Hsr. 224, Ch. 316) 196

O pastor e o cão (Hsr. 222, Ch. 312) 196

O pastor e o lobo criado com os cães (Hsr. 276, Ch. 315) 221

O pastor e o mar (Hsr. 223, Ch. 311) 196 
O pavão e a gralha (Hsr. 244, Ch. 334) 200

O pescador e o atum (Hsr. 21, Ch. 22) 115

$\mathrm{O}$ pescador e o biqueirão (Hsr. 18, Ch. 26) 114

O pescador flautista (Hsr. 11, Ch. 24) (a) 110

$\mathrm{O}$ pescador flautista (Herod. I, 141B ed. Hude = Perry $11 \mathrm{a})(\mathrm{b})$

O pombo sedento (Hsr. 217, Ch. 301) 201

O porco e as ovelhas (Hsr. 87, Ch. 94) 144

O rapaz e o escorpião (Hsr. 215, Ch. 293) 193

O rapaz que comia as entranhas (Hsr. 47, Ch. 292) 127

O rico e as carpideiras (Hsr. 221, Ch. 310) 195

O rico e o curtidor de peles (Hsr. 220, Ch. 309) 195

O rouxinol e o falcão (Hsr. 4, Ch. 8) (a) 105

$\mathrm{O}$ rouxinol e o falcão $(\mathrm{b}) \quad 106$

O rouxinol e o morcego (Hsr. 48, Ch. 75) 128

O touro e as cabras selvagens (Hsr. 242, Ch. 332) 200

O tordo no arbusto de mirtilos (Hsr. 88, Ch. 157) 145

$\mathrm{O}$ vaqueiro que perdeu um bezerro, e o leão (Hsr. 49, Ch. 74)

O veado e a parra (Hsr. 79, Ch. 103) 140

$\mathrm{O}$ veado e o leão numa gruta (Hsr. 78, Ch. 104) 140

$\mathrm{O}$ veado mutilado (Hsr. 77, Ch. 105) 140

O veado na fonte (Hsr. 76, Ch.102) 139

O velho e a morte (Hsr. 60, Ch. 78) 133

O vendedor de estátuas (Hsr. 101, Ch. 2) 150

O viajante e a fortuna (Hsr. 184, Ch. 261) 183

O viajante e Hermes (Hsr. 188, Ch. 260) 185

O viajante e a víbora (Hsr. 186, Ch. 82b) 183

Os anos do homem (Hsr. 107, Ch. 139) 153

Os bois e o eixo (Hsr. 45, Ch. 70) 126

Os burros diante de Zeus (Hsr. 196, Ch. 262) 187

Os cães famintos (Hsr. 138, Ch. 176) 165 
Os caminhantes e o machado (Hsr. 68, Ch. 256) 135

Os caminhantes e o urso (Hsr. 66, Ch. 254) 134

Os caracóis (Hsr. 54, Ch. 173) 130

Os dois cães (Hsr. 94, Ch. 175) 147

Os dois escaravelhos (Hsr. 86, Ch. 149) 144

Os filhos do lavrador que discutiam (Hsr. 53, Ch. 86) 130

Os galos e a perdiz (Hsr. 23, Ch. 21) 116

Os gansos e as garças (Hsr. 256, Ch. 353) 204

Os golfinhos e o golião (Hsr. 73, Ch. 95) 133

Os inimigos (Hsr. 69, Ch. 114) 136

Os ladróes e o galo (Hsr. 124, Ch. 158) 160

Os lobos e as ovelhas (Hsr. 158, Ch. 217) 173

Os marinheiros (Hsr. 80, Ch. 308) 141

Os menargitas (Hsr. 173, Ch. 236) 178

Os pescadores que pescaram uma pedra (Hsr. 13, Ch. 23) 112

Os rapazes e o carniceiro (Hsr. 67, Ch. 246) 135

Os ratos e as doninhas (Hsr.174, Ch. 237) 178

Os viajantes e o corvo (Hsr. 227, Ch. 255) 207

Os viajantes e o plátano (Hsr. 185, Ch. 257) 183

Os viajantes e o tojo (Hsr. 187, Ch. 258) 184

Prometeu e os homens (Hsr. 228, Ch. 322) 209

Um lavrador e a fortuna (Hsr. 61, Ch. 84) 133

Um pescador que batia na água (Hsr. 26, Ch. 27) 118

Zeus e a raposa (Hsr. 109, Ch. 119) 154

Zeus e a serpente (Hsr. 240, Ch. 122) 201

Zeus e a tartaruga (Hsr. 108, Ch. 125) 154

Zeus e Apolo (Hsr. 106, Ch. 121) 153

Zeus e o Pudor (Hsr. 111, Ch. 118) 155

Zeus e os homens (Hsr. 110, Ch. 120) 154

Zeus, Prometeu, Atena e Momo (Hsr. 102, Ch. 124) 151 


\section{EDIÇÓES CRÍTICAS: CORRESPONDÊNCIA DAS FÁBULAS}

Colecçấo Augustana: ORDEM de FÁBulas da RECENSÁo I ${ }^{*}$

\begin{tabular}{|c|c|c|}
\hline Perry (P.) & Hausrath (Hsr.) & Cambry (Ch.) \\
\hline 1 & 1 & 3 \\
\hline 2 & 2 & 5 \\
\hline 3 & 3 & 4 \\
\hline 4 & 4 & 8 \\
\hline 5 & 5 & 10 \\
\hline 6 & 6 & 17 \\
\hline 7 & 7 & 14 \\
\hline 8 & 8 & 19 \\
\hline 9 & 9 & 40 \\
\hline 10 & 10 & 42 \\
\hline 11 & 11 & 14 \\
\hline 12 & 12 & 37 \\
\hline 13 & 13 & 23 \\
\hline 14 & 14 & 39 \\
\hline 15 & 15 & 32 \\
\hline 16 & 16 & 12 \\
\hline 17 & 17 & 41 \\
\hline 18 & 18 & 26 \\
\hline 19 & 19 & 31 \\
\hline 20 & 20 & 35 \\
\hline 21 & 21 & 22 \\
\hline
\end{tabular}

- Segundo Perry 2007, pp. 312-20. Cf. Hausrath 1970, pp. VII-XXXVIII e Hausrath 1959, pp. VII-XII. 
EDIÇÓES CRÍTICAS: CORRESPONDÊNCIA DAS FÁBULAS

\begin{tabular}{|c|c|c|}
\hline 22 & 22 & 34 \\
\hline 23 & 23 & 21 \\
\hline 24 & 24 & 30 \\
\hline 25 & 25 & 28 \\
\hline 26 & 26 & 27 \\
\hline 27 & 27 & 43 \\
\hline 28 & 28 & 55 \\
\hline 29 & 29 & 56 \\
\hline 30 & 30 & 53 \\
\hline 31 & 31 & 52 \\
\hline 32 & 32 & 45 \\
\hline 33 & 33 & 51 \\
\hline 34 & 34 & 46 \\
\hline 35 & 35 & 60 \\
\hline 36 & -.--- & 50 \\
\hline 37 & 37 & 54 \\
\hline 38 & 38 & 64 \\
\hline 39 & 39 & 349 \\
\hline 40 & 40 & 65 \\
\hline 41 & 41 & 36 \\
\hline 42 & 42 & 83 \\
\hline 43 & 43 & 68 \\
\hline 44 & 44 & 66 \\
\hline 45 & 45 & 70 \\
\hline 46 & 46 & 73 \\
\hline 47 & 47 & 292 \\
\hline 48 & 48 & 75 \\
\hline 49 & 49 & 74 \\
\hline 50 & 50 & 76 \\
\hline 51 & 51 & 81 \\
\hline 52 & 52 & 80 \\
\hline
\end{tabular}




\begin{tabular}{|c|c|c|}
\hline 53 & 53 & 86 \\
\hline 54 & 54 & 173 \\
\hline 55 & 55 & 89 \\
\hline 56 & 56 & 91 \\
\hline 57 & 57 & 87 \\
\hline 58 & 58 & 90 \\
\hline 59 & 59 & 77 \\
\hline 60 & 60 & 78 \\
\hline 61 & 61 & 84 \\
\hline 62 & 73 & 95 \\
\hline 63 & 63 & 96 \\
\hline 64 & 64 & 177 \\
\hline 65 & 66 & 254 \\
\hline 66 & 67 & 246 \\
\hline 67 & 68 & 256 \\
\hline 68 & 69 & 114 \\
\hline 69 & 70 & 67 \\
\hline 70 & 71 & $101^{*}$ \\
\hline 71 & 72 & 62 \\
\hline 72 & 74 & 235 \\
\hline 73 & 75 & 305 \\
\hline 74 & 76 & 102 \\
\hline 75 & 77 & 105 \\
\hline 76 & 78 & 104 \\
\hline 77 & 79 & 103 \\
\hline 78 & 80 & 308 \\
\hline 79 & 81 & 13 \\
\hline 80 & 82 & 239 \\
\hline 81 & 83 & 38 \\
\hline 81 & 84 & 269 \\
\hline 83 & 85 & 306 \\
\hline
\end{tabular}


EDIÇÕES CRÍTICAS: CORRESPONDÊNCIA DAS FÁBULAS

\begin{tabular}{|c|c|c|}
\hline 84 & 86 & 149 \\
\hline 85 & 87 & 94 \\
\hline 86 & 88 & 157 \\
\hline 87 & 89 & $288 \mathrm{~d}$ \\
\hline 88 & 90 & 108 \\
\hline 89 & 91 & 110 \\
\hline 90 & 92 & 117 \\
\hline 91 & 93 & 276 \\
\hline 92 & 94 & 175 \\
\hline 93 & 95 & 116 \\
\hline 94 & 96 & 299 \\
\hline 95 & 97 & 49 \\
\hline 96 & 98 & 115 \\
\hline 97 & 99 & 107 \\
\hline 98 & 100 & 106 \\
\hline 99 & 101 & 2 \\
\hline 100 & 102 & 124 \\
\hline 101 & 103 & 162 \\
\hline 102 & 104 & 109 \\
\hline 103 & 105 & 111 \\
\hline 104 & 106 & 121 \\
\hline 105 & 107 & 139 \\
\hline 106 & 108 & 125 \\
\hline 107 & 109 & 119 \\
\hline 108 & 110 & 120 \\
\hline 109 & 111 & 118 \\
\hline 110 & 112 & 131 \\
\hline 111 & 113 & 130 \\
\hline 112 & 114 & 241 \\
\hline 113 & 115 & 132 \\
\hline 114 & 116 & 134 \\
\hline
\end{tabular}




\begin{tabular}{|c|c|c|}
\hline 115 & 117 & 137 \\
\hline 116 & 118 & 150 \\
\hline 117 & 119 & 146 \\
\hline 118 & 120 & 153 \\
\hline 119 & 121 & 154 \\
\hline 120 & 122 & 155 \\
\hline 121 & 123 & 156 \\
\hline 122 & 124 & 158 \\
\hline 123 & 125 & 161 \\
\hline 124 & 126 & 165 \\
\hline 125 & 127 & 170 \\
\hline 126 & 128 & 160 \\
\hline 127 & 129 & 171 \\
\hline 128 & 130 & 167 \\
\hline 129 & 131 & 163 \\
\hline 130 & 132 & 159 \\
\hline 131 & 133 & 164 \\
\hline 132 & 135 & \\
\hline 133 & 136 & \\
\hline 134 & 137 & \\
\hline 135 & 138 & 176 \\
\hline 136 & 139 & 182 \\
\hline 137 & 140 & 189 \\
\hline 138 & 143 & 191 \\
\hline 139 & 144 & 193 \\
\hline 140 & 145 & 198 \\
\hline 141 & 146 & 201 \\
\hline 142 & 147 & 196 \\
\hline 143 & 148 & 211 \\
\hline 144 & 149 & 197 \\
\hline 145 & 150 & 202 \\
\hline
\end{tabular}


EDIÇÕES CRÍTICAS: CORRESPONDÊNCIA DAS FÁBULAS

\begin{tabular}{|c|c|c|}
\hline 146 & 151 & 213 \\
\hline 147 & 152 & 200 \\
\hline 148 & 153 & 204 \\
\hline 149 & 154 & 209 \\
\hline 150 & 155 & 206 \\
\hline 151 & 156 & 208 \\
\hline 152 & 157 & 214 \\
\hline 153 & 158 & 217 \\
\hline 154 & 159 & 225 \\
\hline 155 & 160 & 221 \\
\hline 156 & 161 & 224 \\
\hline 157 & 162 & 220 \\
\hline 158 & 163 & 223 \\
\hline 159 & 164 & 230 \\
\hline 160 & 166 & 231 \\
\hline 161 & 170 & 233 \\
\hline 162 & 171 & 294 \\
\hline 163 & 172 & 234 \\
\hline 164 & 173 & 236 \\
\hline 165 & 174 & 237 \\
\hline 166 & 175 & 242 \\
\hline 167 & 177 & 238 \\
\hline 168 & 178 & 245 \\
\hline 169 & 179 & 248 \\
\hline 170 & 180 & 249 \\
\hline 171 & 181 & 250 \\
\hline 172 & 182 & 251 \\
\hline 173 & 183 & 253 \\
\hline 174 & 184 & 261 \\
\hline 175 & 185 & 257 \\
\hline 176 & 186 & $82 b^{*}$ \\
\hline
\end{tabular}




\begin{tabular}{|c|c|c|}
\hline 177 & 187 & 258 \\
\hline 178 & 188 & 260 \\
\hline 179 & 190 & 273 \\
\hline 180 & 191 & 265 \\
\hline 181 & 192 & $142 f^{*}$ \\
\hline 182 & 193 & 266 \\
\hline 183 & 194 & 264 \\
\hline 184 & 195 & 278 \\
\hline 185 & 186 & 262 \\
\hline 186 & 197 & 277 \\
\hline 187 & 198 & 281 \\
\hline 188 & 199 & 267 \\
\hline 189 & 201 & 271 \\
\hline 190 & 202 & 274 \\
\hline 191 & 203 & 270 \\
\hline 192 & 206 & 286 \\
\hline 193 & 207 & 283 \\
\hline 194 & 208 & 284 \\
\hline 195 & 210 & 148 \\
\hline 196 & 211 & 290 \\
\hline 197 & 212 & 289 \\
\hline 198 & 213 & 291 \\
\hline 199 & 215 & 293 \\
\hline 200 & 216 & 296 \\
\hline 201 & 217 & 301 \\
\hline 202 & 218 & 302 \\
\hline 203 & 219 & 304 \\
\hline 204 & 220 & 309 \\
\hline 205 & 221 & 310 \\
\hline 206 & 222 & 312 \\
\hline 207 & 223 & 311 \\
\hline
\end{tabular}


EDIÇÕES CRÍTICAS: CORRESPONDÊNCIA DAS FÁBULAS

\begin{tabular}{|l|l|l|}
\hline 208 & 224 & 316 \\
\hline 209 & 225 & 313 \\
\hline 210 & 226 & 318 \\
\hline 211 & 230 & 297 \\
\hline 212 & 232 & 321 \\
\hline 213 & 233 & 324 \\
\hline 214 & 234 & 326 \\
\hline 215 & 235 & 330 \\
\hline 216 & 236 & 331 \\
\hline 217 & 242 & 332 \\
\hline 218 & 243 & 307 \\
\hline 219 & 244 & 334 \\
\hline 220 & 246 & 145 \\
\hline 221 & 248 & 122 \\
\hline 222 & 250 & $342^{*}$ \\
\hline 223 & 251 & 342 \\
\hline 224 & 252 & 327 \\
\hline 225 & 253 & 344 \\
\hline 226 & 254 & 352 \\
\hline 227 & 255 & 347 \\
\hline 228 & 256 & 353 \\
\hline 229 & 258 & 348 \\
\hline 230 & 259 & 351 \\
\hline 231 & 260 & 356 \\
\hline
\end{tabular}

Colecçấo Augustana Ia (aCRÉscimos À $1^{a}$ ReCEnsáo)

\begin{tabular}{|c|c|c|}
\hline 232 & 231 & 29 \\
\hline 233 & 247 & 174 \\
\hline 234 & 165 & 229 \\
\hline 235 & 176 & 242 \\
\hline 236 & 227 & 255 \\
\hline
\end{tabular}




\begin{tabular}{|l|l|l|}
\hline 237 & 200 & 263 \\
\hline 238 & 209 & 282 \\
\hline 239 & 214 & 299 \\
\hline 240 & 228 & 322 \\
\hline 241 & 245 & 335 \\
\hline 242 & 241 & 341 \\
\hline 243 & 240 & 240 \\
\hline 244 & 261 & 355 \\
\hline
\end{tabular}

FÁbULAS de OUTROS CÓdices (ausentes da Colecçấo Augustana)

\begin{tabular}{|c|c|c|}
\hline 245 & 290 & 47 \\
\hline 246 & 278 & 88 \\
\hline 247 & 65 & 98 \\
\hline 248 & $65 a$ & 97 \\
\hline 249 & 142 & 147 \\
\hline 250 & 141 & 152 \\
\hline 251 & 271 & 169 \\
\hline 252 & 268 & 180 \\
\hline 253 & 265 & 181 \\
\hline 254 & 134 & 183 \\
\hline 255 & 267 & 188 \\
\hline 256 & 169 & 190 \\
\hline 257 & 167 & 194 \\
\hline 258 & 269 & 205 \\
\hline 259 & 292 & 210 \\
\hline 260 & ----- & 219 \\
\hline 261 & 161 & 222 \\
\hline 262 & 293 & 252 \\
\hline 263 & 204 & 272 \\
\hline 264 & 295 & 276 \\
\hline 265 & 205 & 285 \\
\hline 266 & 229 & 303 \\
\hline 267 & 276 & 315 \\
\hline 268 & 237 & 33 \\
\hline 269 & 238 & 328 \\
\hline
\end{tabular}


EDIÇỐES CRÍTICAS: CORRESPONDÊNCIA DAS FÁBULAS

\begin{tabular}{|l|c|c|}
\hline 270 & 296 & 337 \\
\hline 271 & 297 & 346 \\
\hline 272 & $\ldots---$ & 357 \\
\hline 273 & $\ldots-\cdots$ & 358 \\
\hline
\end{tabular}




\section{Volumes publicados na ColecÇáo Autores Gregos e LATINos - SérIe TeXtos GREgos}

1. Delfim F. Leão e Maria do Céu Fialho: Plutarco. Vidas Paralelas - Teseu e Rómulo. Traduçáo do grego, introdução e notas (Coimbra, CECH, 2008).

2. Delfim F. Leão: Plutarco. Obras Morais - O banquete dos Sete Sábios. Tradução do grego, introdução e notas (Coimbra, CECH, 2008).

3. Ana Elias Pinheiro: Xenofonte. Banquete, Apologia de Sócrates. Tradução do grego, introdução e notas (Coimbra, CECH, 2008).

4. Carlos de Jesus, José Luís Brandão, Martinho Soares, Rodolfo Lopes: Plutarco. Obras Morais - No Banquete $I$ - Livros I-IV. Tradução do grego, introdução e notas. Coordenação de José Ribeiro Ferreira (Coimbra, CECH, 2008).

5. Ália Rodrigues, Ana Elias Pinheiro, Ândrea Seiça, Carlos de Jesus, José Ribeiro Ferreira: Plutarco. Obras Morais - No Banquete II - Livros V-IX. Tradução do grego, introdução e notas. Coordenação de José Ribeiro Ferreira (Coimbra, CECH, 2008).

6. Joaquim Pinheiro: Plutarco. Obras Morais - Da Educação das Crianças. Tradução do grego, introdução e notas (Coimbra, CECH, 2008).

7. Ana Elias Pinheiro: Xenofonte. Memoráveis. Tradução do grego, introdução e notas (Coimbra, $\mathrm{CECH}, 2009)$. 
8. Carlos de Jesus: Plutarco. Obras Morais - Diálogo sobre o Amor, Relatos de Amor. Tradução do grego, introdução e notas (Coimbra, CECH, 2009).

9. Ana Maria Guedes Ferreira e Ália Rosa Conceição Rodrigues: Plutarco. Vidas Paralelas - Péricles e Fábio Máximo. Tradução do grego, introdução e notas (Coimbra, CECH, 2010).

10. Paula Barata Dias: Plutarco. Obras Morais - Como Distinguir um Adulador de um Amigo, Como Retirar Benefício dos Inimigos, Acerca do Número Excessivo de Amigos. Tradução do grego, introdução e notas (Coimbra, CECH, 2010).

11. Bernardo Mota: Plutarco. Obras Morais - Sobre a Face Visivel no Orbe da Lua. Tradução do grego, introdução e notas (Coimbra, CECH, 2010).

12. J. A. Segurado e Campos: Licurgo. Oração Contra Leócrates. Tradução do grego, introdução e notas (Coimbra, CECH /CEC, 2010).

13. Carmen Soares e Roosevelt Rocha: Plutarco. Obras Morais - Sobre o Afecto aos Filhos, Sobre a Música. Tradução do grego, introdução e notas (Coimbra, $\mathrm{CECH}, 2010)$.

14. José Luís Lopes Brandão: Plutarco. Vidas de Galba e Otão. Tradução do grego, introdução e notas (Coimbra, CECH, 2010). 
15. Marta Várzeas: Plutarco. Vidas de Demóstenes e Cícero. Tradução do grego, introdução e notas (Coimbra, $\mathrm{CECH}, 2010)$.

16. Maria do Céu Fialho e Nuno Simóes Rodrigues: Plutarco. Vidas de Alcibiades e Coriolano. Traduçáo do grego, introdução e notas (Coimbra, CECH, 2010).

17. Glória Onelley e Ana Lúcia Curado: Apolodoro. Contra Neera. [Demóstenes] 59. Tradução do grego, introdução e notas (Coimbra, CECH, 2011).

18. Rodolfo Lopes: Platão. Timeu-Critías. Tradução do grego, introduçáo e notas (Coimbra, CECH, 2011).

19. Pedro Ribeiro Martins: Pseudo-Xenofonte. A Constituição dos Atenienses. Tradução do grego, introdução, notas e índices (Coimbra, CECH, 2011).

20. Delfim F. Leão e José Luís L. Brandão: Plutarco.Vidas de Sólon e Publicola. Tradução do grego, introdução, notas e índices (Coimbra, CECH, 2012).

21. Custódio Magueijo: Luciano de Samósata I. Tradução do grego, introdução e notas (Coimbra, CECH/IUC, 2012).

22. Custódio Magueijo: Luciano de Samósata II. Tradução do grego, introdução e notas (Coimbra, CECH/IUC, 2012).

23. Custódio Magueijo: Luciano de Samósata III. Tradução do grego, introdução e notas (Coimbra, CECH/IUC, 2012). 
24. Custódio Magueijo: Luciano de Samósata IV. Tradução do grego, introdução e notas (Coimbra, CECH/IUC, 2013).

25. Custódio Magueijo: Luciano de Samósata $V$. Tradução do grego, introdução e notas (Coimbra, CECH/IUC, 2013).

26. Custódio Magueijo: Luciano de Samósata VI. Tradução do grego, introdução e notas (Coimbra, CECH/IUC, 2013).

27. Custódio Magueijo: Luciano de Samósata VII. Tradução do grego, introdução e notas (Coimbra, CECH/IUC, 2013).

28. Custódio Magueijo: Luciano de Samósata VIII. Tradução do grego, introdução e notas (Coimbra, CECH/IUC, 2013).

29. Custódio Magueijo: Luciano de Samósata IX. Tradução do grego, introdução e notas (Coimbra, CECH/IUC, 2013).

30. Reina Marisol Troca Pereira: Hiérocles e Filágrio. Philogelos (O Gracejador). Tradução do grego, introdução e notas (Coimbra, CECH/IUC, 2013).

31. J. A. Segurado e Campos: Iseu. Discursos. VI. A herança de Filoctémon. Tradução do grego, introdução e notas (Coimbra, CECH/IUC, 2013).

32. Nelson Henrique da Silva Ferreira: Aesopica: a fábula esópica e a tradição fabular grega. Estudo, tradução do grego e notas (Coimbra, CECH/IUC, 2013). 
IMPRESSÃO:

Artipol - Artes tipográficas, Lda.

Zona industrial de Mourisca do Vouga, Apartado 3051 3754-901 ÁguedA 
OBRA PUBLICADA

COM A COORDENAÇÁO

CIENTÍFICA

0
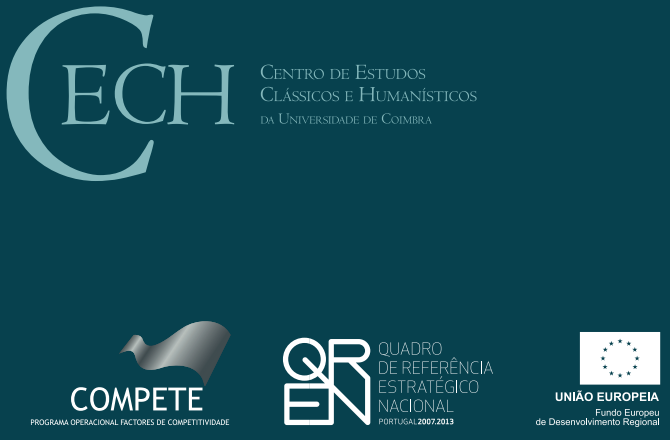